\title{
Debating Humanity
}

Towards a Philosophical Sociology

Daniel Chernilo

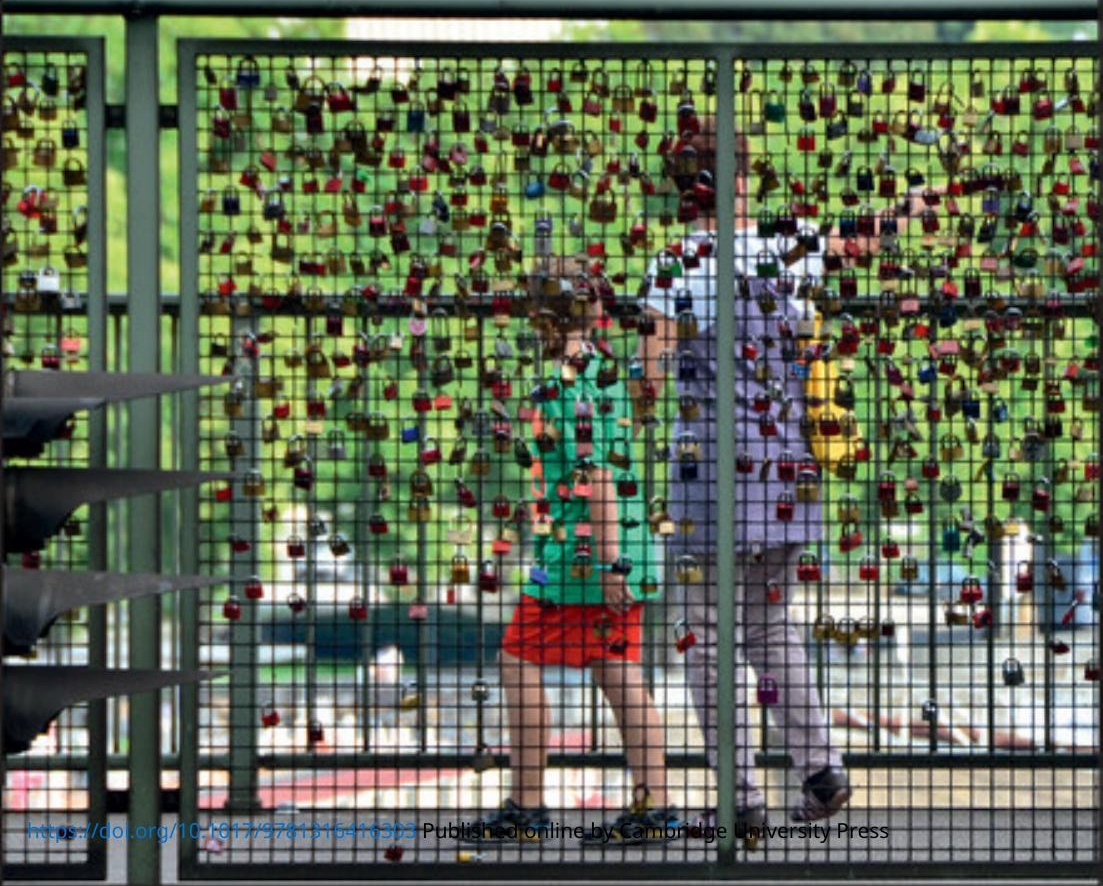




\title{
Debating Humanity
}

\author{
Towards a Philosophical Sociology
}

Debating Humanity explores sociological and philosophical efforts to delineate key features of humanity that identify us as members of the human species. After challenging the normative contradictions of contemporary posthumanism, this book goes back to the foundational debate on humanism between Jean-Paul Sartre and Martin Heidegger in the 1940s and then re-assesses the implicit and explicit anthropological arguments put forward by seven leading postwar theorists: selftranscendence (Hannah Arendt), adaptation (Talcott Parsons), responsibility (Hans Jonas), language (Jürgen Habermas), strong evaluations (Charles Taylor), reflexivity (Margaret Archer) and reproduction of life (Luc Boltanski). Genuinely interdisciplinary and boldly argued, Daniel Chernilo has crafted a novel philosophical sociology that defends a universalistic principle of humanity as the condition of possibility of any adequate understanding of social life.

Daniel Chernilo is Professor of Social and Political Thought at Loughborough University. He has published over forty academic articles in leading scholarly journals and is author of $A$ Social Theory of the Nation-State (2007) and The Natural Law Foundations of Modern Social Theory (Cambridge, 2013). 


\section{Debating Humanity}

Towards a Philosophical Sociology

Daniel Chernilo 


\section{CAMBRIDGE}

UNIVERSITY PRESS

University Printing House, Cambridge CB2 8BS, United Kingdom

Cambridge University Press is part of the University of Cambridge.

It furthers the University's mission by disseminating knowledge in the pursuit of education, learning, and research at the highest international levels of excellence.

www.cambridge.org

Information on this title: www.cambridge.org/9781107129337

$10.1017 / 9781316416303$

(C) Daniel Chernilo 2017

This work is in copyright. It is subject to statutory exceptions and to the provisions of relevant licensing agreements; with the exception of the Creative Commons version the link for which is provided below, no reproduction of any part of this work may take place without the written permission of Cambridge University Press.

An online version of this work is published at http://dx.doi.org/10.1017/978131 6416303 under a Creative Commons Open Access license CC-BY-NC 4.0 which permits re-use, distribution and reproduction in any medium for non-commercial purposes providing appropriate credit to the original work is given and any changes made are indicated. To view a copy of this license, visit https://creativecommons.org/licenses/by-nc/4.0.

All versions of this work may contain content reproduced under license from third parties. Permission to reproduce this third-party content must be obtained from these third-parties directly. When citing this work, please include a reference to the DOI 10.1017/9781316416303.

First published 2017

A catalogue record for this publication is available from the British Library.

Library of Congress Cataloguing-in-Publication Data

Chernilo, Daniel.

Debating humanity : towards a philosophical sociology

Daniel Chernilo.

New York : Cambridge University Press, 2017. | Includes

bibliographical references.

LCCN 2016024595 | ISBN 9781107129337

LCSH: Humanism. | Human beings. | Philosophical anthropology.

LCC B821 .D43 2016 | DDC 128-dc23

LC record available at https://lccn.loc.gov/2016024595

ISBN 978-1-107-12933-7 Hardback

Cambridge University Press has no responsibility for the persistence or accuracy of URLs for external or third-party Internet Web sites referred to in this publication and does not guarantee that any content on such Web sites is, or will remain, accurate or appropriate. 


\section{Contents}

Acknowledgements

page vi

Introduction

1

1 The Humanism Debate Revisited. Sartre, Heidegger, Derrida

2 Self-transcendence. Hannah Arendt 64

3 Adaptation. Talcott Parsons 87

4 Responsibility. Hans Jonas 111

5 Language. Jürgen Habermas 134

6 Strong Evaluations. Charles Taylor 159

7 Reflexivity. Margaret Archer 181

8 Reproduction of Life. Luc Boltanski 206

$\begin{array}{ll}\text { Epilogue } & 229\end{array}$

References 237

Index 255 


\section{Acknowledgements}

The general idea for this book started life with an invitation to speak at the Colloquium 'Identities in conflict, conflict in identities' at the Masaryk University in Brno, the Czech Republic, in 2010. My idea for this talk was, quite simply, to reflect on the elements that constitute the idea of 'human' identities. I have since been able to try out some of my arguments in various conferences, workshops and lectures in: Berlin (2014), Brno (2012) Buenos Aires (2011), Cambridge (2015, 2016), Jena (2011), Leeds (2012), Loughborough (2010), Paris (2015), Rome (2015), Santiago (2010, 2013, 2014, 2015), Temuco (2013), Trento (2012), Turin (2013), Valparaiso (2013) and Warwick (2010, 2014, 2015). I am grateful to the organisers and participants of these events; I hope that they will see that their suggestions and criticisms have been put to good use.

By name I would like to mention those friends and colleagues whose interest, comments and encouragement have greatly helped me complete this project: Omar Aguilar, Rafael Alvear, Nicolás Angelcos, Margaret Archer, Peter Baehr, David Baker, Jack Barbalet, Tom Brock, Brian Callan, Mark Carrigan, Vincenzo Cicchelli, Rodrigo Cordero, Kieran Durkin, Dave Elder-Vass, Robert Fine, Steve Fuller, Ana Gross, Peter Holley, Juan Jiménez, Karen Lumsden, Aldo Mascareño, Sabina Mihelj, Marcus Morgan, Jordi Mundó, Karen O'Reilly, William Outhwaite, Francisco Salinas, Martin Savransky, Csaba Szaló, Bryan S. Turner, Charles Turner, Frederic Vandenberghe and Frank Welz. I am particularly grateful to Rafael and Robert, who commented very generously on most individual chapters and the execution of the whole project. Responsibility for the mistakes, omissions and inaccuracies that remain is mine alone.

As with previous projects, the unconditional love and support of my family and friends - both here and there - have been essential. My deep thanks to Leonor Chernilo, Mara Chernilo, Raúl Chernilo, Rayén Gutiérrez, Paula Mena, Iván Mlynarz, Carla Moscoso, Jorge Moscoso, María José Reyes, Juanita Rojas, Jeannette Steiner, Andrea Valdivia and Andrés Velasco.

vi 
Some sections of the introduction have appeared in: 'On the relationships between social theory and natural law: Lessons from Karl Löwith and Leo Strauss' (History of the Human Sciences 23(5): 91-112, 2010); 'The idea of philosophical sociology' (British fournal of Sociology 65(2): 338-57, 2014); 'Book review: Bruno Latour's An enquiry into modes of existence: An anthropology of the moderns' (European fournal of Social Theory 18(3): 343-48, 2015).

The last part of Chapter 3 builds on: 'The theorisation of social coordinations in differentiated societies: The theory of generalised symbolic media in Parsons, Luhmann and Habermas' (British fournal of Sociology 53(3): 431-49, 2002).

A handful of paragraphs of Chapter 5 draw on: 'Jürgen Habermas: Modern social theory as postmetaphysical natural law' (Fournal of Classical Sociology 13(2): 254-73, 2013). 


\section{Introduction}

This book explores a number of anthropological dimensions that contemporary sociology and philosophy have used to define notions of 'the human', 'human being', 'humanity' and 'human nature'. Rather than declaring the death of the human, or that it incarnates everything that is wrong with 'the West', I contend that we need to look closely at a variety of ways in which these conceptions have been more or less explicitly articulated in the work of a number of leading theorists of the past sixty or so years. I call this project philosophical sociology and organise it around three main pillars:

1. The anthropological features that define us as human beings are to a large extent independent from, but cannot be realised in full outside, social life. The core of this book then looks at seven of these properties as they have been discussed by a particular writer: self-transcendence (Hannah Arendt), adaptation (Talcott Parsons), responsibility (Hans Jonas), language (Jürgen Habermas), strong evaluations (Charles Taylor), reflexivity (Margaret Archer) and the reproduction of life (Luc Boltanski).

2. Given that in contemporary societies humans themselves are ultimate arbiters of what is right and wrong, our shared anthropological features as members of the human species remain the best option to justify normative arguments. These anthropological traits define us as members of the same species and are the basis from which ideas of justice, self, dignity and the good life emerge. A universalistic principle of humanity is to be preferred over particularistic conceptions of race, culture, identity and indeed class.

3. Normative ideas are therefore irreducible to the material or sociocultural positions that humans occupy in society; they depend on the human capacity to reflect on what makes us human; our conceptions of the human underpin our normative notions in social life because they allow us to imagine the kind of beings that we would like to become. This book offers neither a complete nor a unified catalogue of anthropological capacities that can be construed as 'human nature'. 
It focuses instead on those anthropological features that are central to our understanding of the normative aspects of social life.

\section{Sociology and Philosophy}

The notion of philosophical sociology indicates also a preference for a conception of sociology that cannot be realised without a close and careful relationship with philosophy. While the early institutionalisation of sociology was unquestionably driven by an effort of differentiation from philosophy (Manent 1998), it is wrong to construe this as sociology's rejection or neglect of philosophy (Adorno 2000). We can instead observe at least three main ways in which these connections are being constantly redrawn.

A first 'positivist' path understands the philosophical tradition as sociology's pre-scientific heritage, whereas its future belongs to empirical and scientific work. Within the classical canon of sociology, this attitude is arguably best represented by Durkheim (1982) as he engaged extensively in philosophical speculation but sought always to keep both domains distinctly apart. Durkheim remained interested in philosophy and wrote more than occasional works that are indeed philosophical, but he never betrayed his fundamental intuition that he was to contribute to sociology as a specialist subject that was defined by its own theories, methodological rules and internal thematic differentiation (Durkheim 1960, 1970). The key feature of this way of looking at their interconnections is that, however much can be gained from philosophical enquiry, this does not constitute a sociological task sensu stricto (Luhmann 1994, Merton 1964).

A second trajectory is constituted by explicit attempts at epistemological self-clarification. An argument that we can trace back to Weber's (1949) extensive methodological disquisitions, the focus here is on elucidating the logic of sociology's scientific arguments. All such debates as idealism vs materialism, individualism vs collectivism, or realism vs constructivism belong in this category, and we may equally include here a wide range of histories of sociology that have been written in order to illuminate the wider pool of cognitive commitments that inform the sociological imagination (Benton 1977, Levine 1995, Ritzer 1988). Rather than being excluded from sociology, philosophy takes here the well-known role of under-labourer: philosophical tools may be included into the sociologist's kit, but a neat separation between epistemological discussions and substantive empirical work ought to remain in place.

The third approach to the relationships between sociology and philosophy uses the philosophical tradition as a source from which to draw 
various normative motifs (Ginsberg 1968, Hughes 1974). Classically, Marx's (1973) critique of political economy shows the extent to which the fundamentally philosophical motif of critique was to guide his engagement with the 'scientific' procedures or empirical concerns of political economy. Also close to an idea of 'social philosophy', critical social theory is arguably paradigmatic of this kind of engagement in terms of the reconfiguration of normative questions as philosophy's key contribution to scientific sociology (Habermas 1974, Marcuse 1973). Yet this kind of engagement is equally available in 'nostalgic' or even 'conservative' positions within the history of sociology (MacIntyre 2007, Nisbet 1967).

These three approaches to the relationships between philosophy and sociology may not exhaust all possible options but do capture the most salient ones. Neither disciplinary arrogance nor parochialism will do here though: a re-engagement between sociology and philosophy must take the form of a mutual learning process between the different knowledge-claims that underpin them both: the empirical vocation of sociology as it grapples with the complexities of contemporary society and the kind of unanswerable questions that we still associate with the best of the philosophical tradition. At stake is the fact that as long as sociology continues to raise the big questions about life in society - the relative influence of material and ideal factors in historical explanations, the relationships between individual actions and social trends, the interconnections between nature and culture or the dialectics between domination and emancipation - these are all questions that also transcend it: good sociological questions are always, in the last instance, also philosophical ones.

\section{Philosophical Anthropology}

The idea of philosophical sociology achieved some modest visibility in Germany at the turn of the twentieth century. As Georg Simmel (1950) and Ferdinand Tönnies (2005) defined it, philosophical sociology was a form of epistemological self-clarification whose purpose was to contribute to the scientific establishment of sociology. But in the context of a discipline that was still intellectually and institutionally in the making, philosophical sociology was always unlikely to find wide support. Shortlived as it actually was, the project of a philosophical sociology was already building on previous work on philosophical anthropology. ${ }^{1}$

${ }^{1}$ There is no comprehensive account of philosophical anthropology available in English, but see the special section on philosophical anthropology in the inaugural issue of Iris (in particular, Borsari 2009, Fischer 2009, Gebauer and Wulf 2009 and Rehberg 2009). My brief account below is informed by Cassirer $(1996,2000)$ and Schnädelbach (1984). 
An incipient intellectual project, philosophical anthropology looked for a comprehensive answer to the question of what is a human being. Its foundational cohort is primarily associated with the work of Max Scheler and to a lesser extent with that of Ernst Cassirer, both of whom shared a diagnostic with regard to the need for a new discipline that could bring together what we know about what makes us human beings. Writing in 1927, Scheler (2009: 5) opens his The Human Place in the Cosmos with a claim that we have since heard many times: 'in no historical era has the human being become so much of a problem to himself that as in ours'. From medicine to philology, the original project of philosophical anthropology was an attempt to reunite scientific and philosophical knowledge about what is a human being. Crucially, this argument for reunification was made not only in an epistemological key but also in an ontological one: a dual approach to human beings results from, and must be preserved, because of the duality of the human condition itself: humans are partly natural bodies that are controlled by their urges, emotions and physico-chemical adaptation to the world and partly conscious beings that are defined by their intellectual, aesthetic and indeed moral insights.

The rise of philosophical anthropology led also to a fuller realisation that the question 'what is a human being' does not trouble professional intellectuals alone. It rather emerges out of human experiences of and in the world; it is the kind of 'existential' question that is a perennial concern for human beings themselves. As part of the human condition, it is central to religious, mythical and indeed scientific world-views and is to be found across history and through different cultures: a human is a being who asks what is a human being; humans are beings who ask anthropological questions (Blumenberg 2011: 341, 375). At its best, this early programme of philosophical anthropology leads to a universalistic principle of humanity that is built on the following four commitments:

1. Life expresses itself through an upward gradient in complexity that goes from plants, that have little option but to passively adapt to the environment, to animals that make use of their instincts, to humans who can reflexively decide who they are and what they want to do with their existence.

2. Average members of the human species are all similarly endowed with general anthropological capacities that make a key contribution to life in society. Human beings recognise one another as members of the same species because of these shared anthropological endowments. ${ }^{2}$

${ }^{2}$ In contemporary philosophy, the so-called Capabilities Approach may be taken as one tradition that builds on previous insights from philosophical anthropology (Nussbaum 1992, 2006, Sen 1999). Interestingly, this is now finding a voice also within sociological debates (Gangas 2014, 2016). 
3. The human body has an ambivalent position for humans themselves: it is an object in the natural world, it is the 'container' of our anthropological features and it is also a cultural artefact.

4. Given that human nature is ultimately indeterminate vis-à-vis social and cultural relations, humans do turn themselves into an explicit concern.

For my purposes in this book, by far the most consequential intervention in this early delimitation of philosophical sociology and philosophical anthropology comes from Karl Löwith's 1932 book Max Weber and Karl Marx. Arguably best known for his discussion of secularisation (Löwith 1964) and his perceptive criticisms of Heidegger (Löwith 1995), the main contention of this little book is that the importance of both Weber and Marx lies in that they successfully brought together the two intellectual genres in which we are interested: the venerable concerns of philosophy with the idea of 'man' and the fresh start that was offered by the interest of the social sciences in 'capitalism'. The latter was of course the explicit focus of Weber and Marx: they were equally trying to understand capitalism and offered radically different accounts of its emergence and functioning. But there is also a philosophical layer to their writings that, in Löwith's interpretation, is in fact more significant. There, he contends, their apparent differences are sublated into a fundamental common ground: the core 'of their investigations is one and the same ... what is it that makes man "human" within the capitalistic world' (Löwith 1993: 42-3). This anthropological enquiry into what is a human being was surely not the explicit goal of either writer, but therein lies nonetheless 'their original motive' (1993: 43). Weber and Marx offered a new kind of intellectual enquiry that was, simultaneously, empirically informed and normatively oriented, and this was precisely what made them 'philosophical sociologists' (Löwith 1993: 48). It is through the combination of scientific and philosophical approaches that they addressed fundamental intellectual questions: the interplay of material and ideal factors in human life, the immanent and transcendental condition of historical time, the relationships between social action and human fate, the disjuncture between existential concerns we all share as human beings and our particular socio-historical contexts. In Löwith's reconstruction, therefore, Marx's idea of humanity is fundamentally informed by his understanding of alienation - a world that must be wholly transformed because it impedes human development - while Weber is concerned with the inevitable flattening of our human concerns in a modern world that allows only for specialism, bureaucratisation and disenchantment.

Deeply rooted in its own intellectual traditions, this first generation of philosophical anthropology did not fully realise the extent to which natural 
scientists had already stopped asking for philosophy's permission when it came to asking questions about the human condition: the biological sciences rather than philosophy were making knowledge about the human to advance at an unprecedented rate (von Uexküll 2010). On the one hand, if science was setting the new standards, then the philosophical drive of philosophical anthropological looked somewhat inadequate: as a project that needed to confront the challenges of the contemporary scientific civilisation, philosophical anthropology, looked old before it really got going. ${ }^{3}$ On the other hand, philosophical anthropology was looked at with scepticism even within professional philosophy itself. To Edmund Husserl (1931), who at the time was the leading German philosopher, philosophical anthropology seemed second-rate philosophy because the psychological and physiological limitations of the human mind were never going to live up to the standards of the general questions about mind, consciousness and reason in general. ${ }^{4} \mathrm{~A}$ mere interest in the human, the more so as it now had to include the 'lower' biological functions of human life, was never going to replace philosophy's enduring concerns.

If we now include also the turbulent historical period within which philosophical anthropology emerged, there was perhaps something inevitable in its rapid demise as a field of study. In a context of volatile nationalistic passions, growing state institutions, urbanisation and industrialism, militarisation and colonial wars, hyperinflation and the rise of mass political parties, a concern with the human in general, let alone a belief in a unified theory of the human under the tutelage of philosophy, could be seen as dramatically out of touch. Whole populations or collectives were being pushed outside the human family (if they were ever permitted to sit at this high table in the first place), political democracy was scoffed by traditional elites and dismissed as mere bourgeois ideology by revolutionaries, and the individual was being sacrificed on behalf of the nation, the party, the revolution and indeed humanity itself. In a world that seemed dominated by power struggles, capitalism, technological innovations and particularistic ideas of nation and race, the venerable Kantian idea that humans be treated as ends and never as means rang idealistic at best. ${ }^{5}$

${ }^{3}$ This is, in effect, Jürgen Habermas's (1992a) argument on the relationship between science and philosophy in Postmetaphysical Thinking. See also Chernilo (2013b).

4 To that extent, Heidegger's equally ambivalent relationship to philosophical anthropology echoes Husserl's doubts, though in his case the general scepticism is based on an irrationalist and elitist understanding of being. See Chapter 1.

${ }^{5}$ Or, differently put, the 'revival' of German philosophical anthropology in the early part of the twentieth century can be seen as a reaction to the success of philosophies of history in public discourse as apparent, for instance, in Oswald Spengler's hugely popular Decline of the West, whose first volume was originally published in 1918 . 
The massacres and crimes of World War II did not make things easier for philosophical anthropology and yet it was in its aftermath where it arguably experienced the peak of its influence and public exposure. Closely associated with the works of Arnold Gehlen $(1980,1988)$ and Helmut Schelsky (1967) - both of whom were Nazi sympathisers a second generation of philosophical anthropology gave up on the original humanistic concerns of Cassirer and Scheler and instead helped articulate such conventional conservative concerns as the dangers of technology and the erosion of community. ${ }^{6}$ The humanist sensibility was not altogether abandoned, however, as apparent in Helmuth Plessner's (1970) influential work Laughing and Crying, who once again tried to reunite the organic and intellectual dimensions of human life. ${ }^{7}$ Finally, towards the last part of the twentieth century, a third generation of philosophical anthropology has emerged. Here, the ontological convictions that defined the first generation were now being given up: Odo Marquard's (1989) homo compensator and Hans Blumenberg's (2011) reflections on the powers of human delegation, both point to a description of our generic anthropological potentials. Yet their anti-foundationalist definition of the human can hardly be reconciled with previous notions of human nature.

\section{Homo Sociologicus}

Given that this book looks at the relationships between philosophy and sociology, let me now look more closely at some instantiations of these general reflections about the human within mainstream sociology. Ralf Dahrendorf, who among other accolades was director of the London School of Economics between 1974 and 1984, wrote two early pieces that deal directly with the questions that concern us here: Homo Sociologicus, in 1957, and a follow-up essay Sociology and Human Nature, in 1962. Dahrendorf uses the term philosophical sociology only in passing and in order to emphasise the inability of European sociology to differentiate between philosophical/normative concerns, on the one hand, and strictly empirical/scientific ones, on the other (1973: 78). As sociology's maturity depends on a strict separation between these two domains, Dahrendorf praises American social science for having made the idea of the 'social role' central to this demarcation. Homo sociologicus is thus introduced as the disciplinary equivalent of homo oeconomicus in modern

${ }^{6}$ See, for instance, Axel Honneth's (2009) critique.

${ }^{7}$ Plessner was Jewish and had been subject to persecution by the Nazis, so his reinstatement in German academia also contributed to the intellectual rehabilitation of philosophical anthropology. On Plessner, see Heinze (2009) and the more recent collection that was put together by Jos de Mul (2014). 
economics and 'psychological man' in twentieth-century scientific psychology: where the former is interested in the calculation of possibilities for personal gain, the latter's behaviour is always underpinned by unconscious motifs that can never become fully clear to the individual herself. On the basis of the scientific success of modern economics and psychology, it was now sociology's turn to clearly delimit the one aspect of human behaviour that constitutes sociology's genuine subject matter: ' $[\mathrm{t}] \mathrm{o}$ a sociologist the individual is his social roles' (Dahrendorf 1973: 7).

The scientific constructions of Homo oeconomicus, homo psychologicus and homo sociologicus share two important features. First, they all seek to capture that particular point at which the individual and society intersect: individual preferences/objective conditions for homo oeconomicus, unconscious drives/social norms for homo psychologicus, personal capabilities/social performance for homo sociologicus. Second, none offers a comprehensive theory of human nature but is instead construed as a unilateral exaggeration of one particular anthropological feature that has proved particularly useful from one, equally particular, disciplinary point of view. In defining homo sociologicus as stable and predictable role-conforming behaviour, sociology 'explicitly renounces a sociological image of man: it proclaims the intention of finding powerful explanatory theories of social action rather than describing the nature of man accurately and realistically' (Dahrendorf 1973: 76, my italics). ${ }^{8}$

From a scientific standpoint, Dahrendorf contends, this is a win-win situation because the net increment in the predictive capability of sociology leads also to a realisation of the futility of metaphysical speculation. But given that social scientific concepts belong also in public and political discourse, the wider philosophical underpinnings of homo sociologicus react back on society's self-understanding. Dahrendorf (1973: 59) then argues that '[s] ociology has paid for the exactness of its propositions with the humanity of its intentions, and has become a thoroughly inhuman, amoral science'. He elaborates as follows on this challenge:

If the assumption of role conformity has proved extraordinarily fruitful in scientific terms, in moral terms the assumption of a permanent protest against the demands of society is much more fruitful. This is why an image of man may be developed that stresses man's inexhaustible capacity for overcoming all the forces for alienation that are inherent in the conception and reality of society. (Dahrendorf 1973: 84, my italics)

\footnotetext{
${ }^{8}$ A general overview of the problems associated with thinking about the relationships between ideas of the human and ideas of social can be found in Hollis (1977: 1-21). For an exploration of ideas of human nature in classical sociology, see Honneth and Joas (1988).
} 
One implication of this discussion is that, to the extent that we engage both with ideas of the human and conceptions of the social, we can never fully separate out descriptive and normative concerns. They must be distinguished analytically, and we ought to be able to discuss them separately, but we need also explore their interrelations. And it also shows that, to the extent that we base our reflections on the human on reductionist anthropological accounts, these find expression in, and have dramatic consequences for, our conceptions of the social. The problem does not lie in any specific shortcoming of homo oeconomicus, homo psychologicus or homo sociologicus but in the fact that, as they are by definition unilateral reductions of our human capacities, the alleged success of their scientific contribution cancels itself out in terms of the normative shortcomings it also obtains. The study of social life requires instead a universalistic principle of humanity that offers a richer account of our defining anthropological features. Indeed, Dahrendorf's passing comment on the 'inexhaustible capacity for overcoming' the forces of conformity and alienation speaks directly about the human abilities of self-transcendence and reflexivity. ${ }^{9}$

Sadly, however, mainstream contemporary sociology does not seem to have learned the right lessons on this issue. Committed as he is to political causes, Pierre Bourdieu engages constantly with normative questions. But Bourdieu does not conceptualise normativity sociologically; normative ideas are not included as an actual dimension of the social world because conflict and power struggles are deemed enough for a fully formed ontology of the social: ' $[t]$ he particularity of sociology is that it takes as its object fields of struggle - not the field of class struggle but the field of scientific struggles itself. And the sociologist occupies a position in these struggles' (Bourdieu 1994: 10). The normative motif of his militant sociology is that the interests of less powerful actors ought to be favoured against those of more powerful ones, so the role of the sociologist is to help subordinate actors get their interest advanced wherever and whenever this is needed. ${ }^{10}$ My difficulty is not at all with Bourdieu's political options but with the shallow anthropology that underpins it: sociology 'inevitably appeals to anthropological theories ... it can make real progress only on condition that it makes explicit these theories that researchers always bring in ... and which

${ }^{9}$ Dahrendorf's critique is directed primarily against Parsons. See Chapter 3.

${ }^{10} \mathrm{I}$ focus on Bourdieu given his mainstream status in contemporary sociology: by September 2016, Pierre Bourdieu carried more citations in Google Scholar than Weber and Marx combined. But the general argument applies also, for instance, to Niklas Luhmann even if for opposite reasons. According to Luhmann (1994), it is sociology's excessive normativism that is responsible for the discipline's chronic underachievements. The result is, however, comparable to Bourdieu's: normative questions are of no particular relevance to sociology because there is no autonomous normative domain in society itself. See Chernilo (2012d). 
are generally no more than the transfigured projection of their relation to the social world' (Bourdieu 1994: 19, my italics).

Knowingly or otherwise, Bourdieu follows Dahrendorf here: we ought to take our anthropological presuppositions seriously and make them explicit because they are a transfigured projection of our own conceptions of the social world. If we assess how Bourdieu's own arguments fare on these questions, we see that a reductionist notion of self-interests at the anthropological level is then coupled by an equally reductionist conception of the social as a space of constant struggle:

There is a form of interest or function that lies behind every institution or practice ... the specifically social magic of an institution can constitute almost anything as an interest and as a realistic interest, i.e. as an investment (both in the economic and the psychoanalytic senses), that is objectively rewarded, in the more or less long term, by an economy. (Bourdieu 1994: 18)

Because interests lie behind every institution and practice, Bourdieu's sociology predicts a world of winners and losers and anticipates on which side our normative loyalties should be. We may then account for the structural features of various social contexts, but remain unable to grasp what is normatively at stake because irreducible normative ideas are not part of this version of homo sociologicus. In fact, the irrationalist conception of human nature offered by Bourdieu mirrors those offered by equally one-sided, arguments on, say, primordial authenticity (Connell 2007). This 'normative-less' depiction of social life has become sociology's very own self-fulfilling dystopia: we do not take normative factors into account as part of what we have to explain sociologically because our ontologies of the social allow for no concept of the normative. ${ }^{11}$

\section{A Post-Human World?}

The references I have briefly discussed up to now remain relatively conventional not only in terms of their disciplinary reference point within sociology but also in the sense that they all speak directly about a kind of being that is more or less explicitly and confidently described as 'human'. But whether this is in fact an adequate claim is precisely the question that seems most pressing nowadays. Under the general banner of posthumanism, we find artificial intelligence and cognitive science experts who discuss the uniqueness of the biological makeup of the human species, science and technology experts who redraw the contours of the human through its interactions with various other domains of reality, global

11 Reinhard Bendix (1970: 3-61) had already warned about the problems of a dual irrationalism in our preconceptions of the human and our theories of the social. 
warming and animal rights activists who challenge the destructive and indeed self-destructive features of modern anthropocentrism, and postcolonial and gender scholars who highlight the whole range of violent exclusions that have been justified by anything but benevolent Western ideas of humanity. These positions come from different angles and have their own targets of critique, but they can be grouped together if we consider that they are all interested in the wrong presuppositions and negative implications of modern anthropocentrism and, by implication, humanism. $^{12}$

I have of course written this book within this intellectual climate but below will not be engaging with these arguments systematically. Ideas of humanity are of course socially construed, change historically and are full of highly problematic assumptions at cognitive, theological and normative levels (Foucault 1997). But nowadays it takes too little effort to challenge so-called 'traditional' ideas of the human and then make the additional claim that they are ultimately to blame for all of modernity's sins. I reject these claims and suggest that we use them as an invitation to step back and interrogate again the status of our conceptions of the human. But in order to do this, we cannot start with spurious claims to novelty - and not only because there is nothing less original than claims to originality. This fallacy of presentism misses the key insight that the very quest about what makes us human is paradigmatic of the all too human frustration with the irritating inevitability of the question of what it means to be human. When posthumanists reject the foundationalism that underpins traditional 'humanist' ideas, all their key motifs (growing knowledge of human biology, the challenges and opportunities of technology, the aporias of anthropocentrism) are precisely those that, under different names, had been raised for well over 200 years. It is impossible for me to survey the various bodies of literature that have touched on these issues over the past few decades. For the purposes of this introduction, I would simply like to illustrate further my argument by discussing, in paradigmatic fashion, recent interventions in three different fields.

Bruno Latour's work is well known for having made claims about the definitive need for a whole new ontology that, as it offers a radical redescription of concepts of the social, culture and nature, seeks also to do without the distinction between humans and nonhumans (Latour 1993).

${ }^{12}$ Badmington's (2000) collection is illustrative because, under the loose banner of posthumanism, it brings together Fanon's critique of Western imperialism, Donna Haraway's work on cyborgs, Roland Barther's semiological analysis and Althusser's virulent anti-humanism. See Kieran Durkin's (2014: 129-43) excellent discussion of early incarnations of anti-humanism from a standpoint that is compatible with the arguments that I am offering here. 
In his recent An Enquiry into the Modes of Existence, for instance, Latour specifies further the idea of 'networks' that is one of his major conceptual contributions. He speaks now of 'series of associations', 'series of instauration' and 'chains of references' which, as they are a form of becoming, allow him to contend that stability resides in change, solidity in flexibility, necessity in contingency, universality in particularity, etc. (Latour 2013: 33, 154-62). He also touches on sociology's conventional depiction of law, politics, the economy, etc. as differentiated systems, fields or value spheres and, again, turns conventional disciplinary wisdom upside down. Rather than concentrating on the autonomy of each of these domains, it is their heteronomy that we ought to be interested in: non-legal elements create law, non-political ones create politics, noneconomic ones create the economy (Latour 2013: 29-35, 130-49).

As methodological or indeed conceptual propositions, these claims are all suggestive and, to Latour's credit, they have proved valuable in several empirical domains; most notably science and technology studies. Methodologically, humans are not only agents and technologies are never fully passive; conceptually, our modern conceptions of nature, society and culture are always in need of redefinition. But these claims neither require nor justify the ontological dissolution of the human. Offered as a new ontology, the stakes are indeed higher and Latour's arguments appear far more problematic. A first question has then to do with whether 'nature', 'society' and 'culture' actually exist but they have been badly misunderstood by the moderns - they are hybrids rather than self-contained domains - or whether they do not exist at all and the real constituents are in fact hybrids themselves. See, for instance:

even though we construct Society through and through, it lasts, it surpasses us, it dominates us, it has its own laws, it is as transcendent as Nature ... The critical power of the modern lies in this double language: they can mobilize nature at the heart of social relationships, even as they leave Nature infinitely remote from human beings; they are free to make and unmake their society, even as they render its laws ineluctable, necessary and absolute. (Latour 1993: 36-7)

It is really not clear which way we should go: if the problem is that of how to conceptualise nature and society, then the issue is not an ontological one and can be best addressed theoretically or even methodologically. But if Latour is really pushing for a new ontology, then the one he now offers is not at all richer than the conventional one that knew at least of nature, culture, society and humans. We now have instead a cosmos that has completely flattened and is populated by networks alone: only networks are real because they are well constructed, only networks are viable because they speak various languages, only networks allow unstable 
components to become 'scientific', 'artistic' or 'economic'. Ontological plurality fails to emerge because all is now subordinated to an endless flow of networks; all we can learn and experience we learn and experience because it has successfully become real as a network.

A second issue refers directly to the question of the status of the human inside Latour's work. The problem here can be introduced in the same way as above: either do humans exist but we have never understood them (in a milder form: modern Western metaphysics has fundamentally misconstrued humanity) or they don't exist and this is what explains the difficulties we have in understanding the world. Similar to what happens to the argument on the differentiation of various domains, one is reminded here of Niklas Luhmann's (2012) thesis that individuals are external to society. ${ }^{13}$ But what for Luhmann counted above all as a requirement of methodological consistency (and even in that softer case it remained always a constant source of epistemological and normative headaches), Latour has again turned this into an ontological issue. Quite clearly, however, it is one thing to accept that the traditional volitional, dispositional, affective and indeed moral connotations of the human are in need of permanent redefinition - I should like to think that my book is a contribution to that kind of reflection - and quite another to uphold the full reversibility that Latour favours: humans are visible only if and when they are part of a network. My point is simple - banal even - and suggests that the very terms with which Latour himself justifies his intellectual enquiry do require a strong and in fact highly conventional conception of the human. In We Have Never Been Modern, for instance, he is concerned with such questions as global warming and the atomic bomb and in An Enquiry into the Modes of Existence he speaks at length about the revival of fundamentalism, poverty, misogyny and colonialism as well as ubiquitous ecological dangers (Latour 2013: 142-56, 268-91). But because these are only understandable as normative motifs, he has to affirm in practice what he rhetorically denies: the 'wes' and 'theys' that ultimately care for these problems are, of course, human beings. ${ }^{14} \mathrm{Can}$ there be anything more modern than Latour's dissatisfaction with modernity's own self-descriptions? His work belongs to the decidedly modern genre in which modernity is in permanent need of full reconsideration: it is a thoroughly modern attempt to account for the modern dissatisfaction

${ }^{13}$ On the sociological and philosophical implications of Luhmann's position, see Mascareño (2012) and Miranda (2012). I briefly come back to this question in the Epilogue.

14 There is, even, a humanist plea that humans have not counted enough throughout human history: 'humans have always counted less than the vast population of divinities and lesser transcendental entities that give us life' (Latour 2004: 456). 
with the modern experience of unfulfilled promises that come out of modernity's own successes and failures. Above all, it offers a view that modernity can only be described adequately if we do so on the basis of the same claim to originality that is so dear to the moderns: this time, however, we shall succeed.

My second example comes from Rosi Braidotti's (2013) recent book on posthumanism and a first thing to note is that her work belongs to a genre that is constituted by its own rules: the kind of arguments that Latour substantiates by some form of first-hand empirical research are here introduced through a combination of speculative, philosophical and scientific arguments that are then fleshed out through examples coming from science fiction, popular culture and political criticism. In Braidotti's version, modernity is defined by two fundamental processes: the constant obsession with technological innovations and a general trend towards the transvaluation of values. While these are fundamentally ambivalent processes because they offer both challenges and opportunities, her critical standpoint is that, what emerges through promises of emancipation for all has, on the contrary, been built on the systematic exclusion of the many. Through her debt to Deleuze and Guattari, Braidotti's critique of humanism belongs directly in the lineage that can be traced back to Heidegger's fundamental conviction that the modern belief in humanity is a pernicious illusion and that 'Humanism' (with capital $\mathrm{H}$ ) is nothing but the violent and exclusionary master-ideology of the West that encapsulates all that is wrong with modernity (Braidotti 2013:13-30). This is arguably the central tenet of the posthumanist literature: humanism as a viable articulation of our contemporary normative sensibility is already dead (Davies 1997). ${ }^{15}$

Braidotti also follows postmodern Heideggerianism when she claims that, although her arguments may appear to be a form of anti-humanism, this is not in fact the case. This inability to commit fully to an anti-humanist

${ }^{15}$ Braidotti is arguably more committed to posthumanism than other salient writers in this field; for instance, Donna Haraway (2008: 19) explicitly disavows the use of the term. Given her reliance on Latour's ontology and the reductionist account of normativity that transpires in her adoption of intersectionality theory, however, my criticism above applies. Even more poignant, however, is the fact that all Haraway's main arguments about species coming together make perfect sense from the most radical of anthropocentric perspectives: hers are stories of people who love animals and change the way they see and relate to the world, including themselves, because they love animals. Given that the humans she speaks about are ultimately common people, it is no surprise that she $i$ able to articulate her normative motifs far more consistently than Braidotti. Also, William Connolly (2011) offers a nuanced redefinition of agency beyond anthropocentrism and one may argue that his reference to the 'human predicament' stands against posthumanism. Yet his argument on becoming pushes him towards the posthumanist mainstream. 
perspective can be explained by the fact that, both cognitively and normatively, she requires an idea of subjectivity which cares about the world and is worth caring for. Subjectivity remains a key theoretical cornerstone of her posthumanist project because only there can she anchor the agency that needs to be defended and promoted (2013: 50-4). Anti-humanism is here found untenable on grounds that are indeed similar to Latour's: first, because as a form of critique, Braidotti's discourse requires normative motifs that, despite the rhetoric, can only be introduced as human concerns for dignity, justice, solidarity and freedom. Second, human beings matter because they are the ones who mobilise normative ideas in society, they are the ones who are in possession of the creative capacities of human action itself. As she deconstructs the injustices and aberrations of humanist discourses - anthropocentrism, androgenism, racism - Braidotti has no difficulty in ubiquitously appealing to these same traditional humanist values. The explorations into the limits, exceptions and contradictions of Western humanism are potentially illuminating, but the Heideggerian influence is again apparent in the elitism that ensues. On the one hand, her whole normative project depends on the need to speak 'on behalf' of those who cannot do so themselves and, whether we like it or not, this is a quintessentially modern political issue. On the other hand, Braidotti does not really know what to do with the values and institutions of the modern world: she derides them as merely ideological but does not reflect on the fact that she can only do so because she takes them for granted: people die every day for the right to work, basic human decency and equality before the law. ${ }^{16}$ Quite rightly, Braidotti takes issue with a mistaken logic of reconciliation that underpins various forms of humanism; in her view, the intrinsic violence that is involved when the particular is sublated in the universal. But rather than radically questioning this way of thinking, she merely inverts the normative vector so that humanism can now be construed as wholly negative - i.e. the intrinsically racist, violent and exclusionary ideology of white, adult, heterosexual and bourgeois men who have exported themselves violently the world over. This 'intersectionality of privilege' is different from an intersectionality of exclusion only because dystopianism has now replaced older ideas of reconciliation. Post-humanists cannot consistently articulate their normative positions because they are unable to clarify what is exactly the human core for which they are prepared to make a positive case. ${ }^{17}$ As Hans Blumenberg (1987: 179) ironically

${ }^{16}$ Interestingly, a toned-down version of this argument can be found in Charles Taylor's (1989: 6) uncritical remark, in the opening of Sources of the Self that, when it comes to these values, 'we are all universalists now'. Sadly, we are anything but (see Chapter 6).

17 There is a parallel literature on trans-humanism that, against the posthumanist mainstream, retains the more conventional humanist notion that our species still holds pride of place in the cosmos. Their redefinition of the human centres on the extent to which 
remarks: 'The final and most subtle forms of anthropocentrism always remain hidden from their critics'. ${ }^{18}$

Let me finally turn to the fields of cognitive science and artificial intelligence, where I would like to focus on the work of Edinburgh philosopher Andy Clark (2001, 2003). One of the original proponents of the so-called 'extended mind' thesis (Clark and Chalmers 2008 [1998]), he has argued that the ways in which we understand our cognitive skills cannot be reduced to self-contained processes that occur inside our 'skin and skull'. Rather, he suggests that we can only explain cognitive processes if we allow in and explain the role of all sorts of external factors - buildings and smartphones, pens and books. This can be seen as a form of posthumanism because it points towards the softening - if not the downright dissolution - of a self-contained idea of the human being and its agential powers. Clark then rejects the idea that 'the cognitive' can be defined unproblematically and indeed makes these reflections on cognitive processes central to the comparison between the two main 'creatures' he is interested in: humans and robots (Clark 2008: 86). For our purposes, there are three main tenets of this argument that are particularly relevant:

1. Humans are defined by the constant interplay between mind, body and world and to that extent they are anything but 'locked-in agents' (Clark 2008: 30). Rather than looking at the differences between internal process that allegedly occur 'inside' our body/mind and external ones that take place 'out there' in the world, Clark contends that all cognitive operations truly occur in their interface. While robots are of course unlike humans in several regards, the key argument is that in its outcomes, their cognitive stance is potentially indistinguishable from those of humans. ${ }^{19}$

current technological innovations may enhance our cognitive skills while making our continuous organic existence potentially unnecessary. Building on the 'precautionary' tradition of philosophical anthropology, however, my position is that, should our carbon materiality be eventually replaced by a silicon one, a 'proactionary' principle may have become redundant because we would have ceased to be human in any meaningful way vis-à-vis past and present experiences of it. See Fuller (2011) and Fuller and Lipinska (2014).

18 The normative thrust of the argument has been well captured by Gillian Rose (1995: 117): 'Previously, modern philosophical irrationalism was seen retrospectively by philosophers and historians as the source of the racist and totalitarian movements of the twentieth century. Now, philosophical reason itself is seen by postmodern philosophers as the general scourge of Western history. To reason's division of the real into the rational and the irrational is attributed the fatal Manichaeism and imperialism of the West'. For this reason, below I will be paying no consideration to disingenuous, cynical, partial or deluded appeals to humanist values.

19 The common reference point here is Alan Turing's (2005 [1950]) famous imitation game that was devised in order to answer the question 'can machines think?'. In a game whose 
2. The design of robots as increasingly intelligent and indeed mobile creatures is a major resource in helping us to better understand cognitive and indeed wider mechanical processes of human beings themselves. This is an argument that resembles traditional etiological and sociobiological notions that humans can and do learn about themselves as they compare their own ways of doing things with those of others creatures: 'The human agent', says Clark, 'is nature's expert at becoming expert' (2008: 75).

3. While technological innovations have been a constant throughout human history, we now witness a new phase in which we move from 'mere' embodiment to more recent technologies of 'basic' and 'profound' embodiment. Similar to Scheler's tripartite classification of plants, animals and humans, Clark also speaks of an incremental degree of openness in the reactions to external stimuli. The current generation of humans are 'natural-born cyborgs' because we have grown predisposed to permanently innovate technologically on central dimensions of our human existence: 'A profoundly embodied creature or robot is thus one that is highly engineered to be able to learn to make maximal problem-simplifying use of an open-ended variety of internal, bodily, or external sources of order' (2008: 43, my italics).

We can see the way in which all three propositions point in a posthumanist direction. Not only do they favour a levelling out between humans and robots, they reject conventional notions that humans are self-contained and discard ideas of human supremacy and exceptionalism. When humans are treated as creatures in a way that resembles animals, plants, robots and cyborgs, then the artificial can teach the natural. In contradistinction to Latour or Braidotti, however, Clark does not make the final ontological move of posthumanism. Rather than dissolving the human, he emphasises that there is an ultimate organic reference to humans:

[i]n rejecting the vision of human cognitive processing as organism bound, we should not feel forced to deny that it is (in most, perhaps all, real-world cases) organism centered. It is indeed primarily (though not solely) the biological organism that, courtesy especially of its potent neural apparatus, spins and maintains (or more minimally selects and exploits) the webs of additional structure that then form parts of the machinery that accomplishes its own cognizing ... Individual cognizing, then, is organism centered even if it is not organism bound. (Clark 2008: 123)

goal is to find out whether your interlocutor is male or female, there is a third participant that will offer various clues. If a machine is able to play this third-party role as well as a human would, then Turing contends that for all practical purposes we can say that the machine can think. See, classically, John Searle's (2005 [1980]) critique of Turing's thought experiment and Margaret Boden's (2005) critique of Searle. 
This argument that cognitive expansion depends on an organic core is one that I would like to retain. Clark compares different forms of creatures and argues for the autonomy and even superiority of machines with regard to a growing range of cognitive skills and processes. What matters to us, however, is that there is also a fundamental ontological irreversibility built into his claims: there is always, ultimately, a problem of design. On the material side, there is the human skill of building robots and technologies which can 'do stuff'. More importantly, on the ideational side, this whole body of literature depends on the imagination of all kinds of thought experiments that allow for the testing of various arguments and counter-arguments: building robots is something humans have an interest in, care about, and this is the reason why they do it. If and when robots act 'autonomously' (and the term is of course very problematic), they are still working within a causal chain that was triggered by human motivations and actions. It is the refreshingly ludic side of this literature that makes my point: colleagues seem to really be having fun at trying to outwit one another. Thus seen, my argument then does not change if machines get much better than humans at playing chess, if machines create new games that are very much like chess, or even if machines create machines whose purpose is to create new games that are far more challenging than chess. What is uniquely human is the original impulse that leads us to play games at all: having fun, socialising, creating and improving on rules, getting better at them, etc. ${ }^{20}$

\section{Structure of the Book}

Chapter 1 looks closely at the discussion on humanism that took place between Jean-Paul Sartre and Martin Heidegger right at the end of the Second World War. In Existentialism Is a Humanism, Sartre offered a defence of traditional humanist values - freedom and autonomy for all on the traditional grounds of anthropocentrism - 'man' is the measure of all things - and constructivism - the world we inhabit is wholly of human making. In Letter on Humanism, Heidegger responded by making three fundamental counterclaims: First, through its egalitarianism and constructivism, humanism is itself to blame for the war and its atrocities; second, 'man' cannot be made a source of value so we ought to worship higher forms of 'being'; and third, a new elite of poets and thinkers is needed to restore human dignity; they are to become the self-appointed 'shepherds of being'. I then look at Jacques Derrida's intervention in this

${ }^{20}$ Differently put, at stake here is not so much a question of artificial intelligence but of artificial life itself. 
debate in order to construe more fully the post- and indeed anti-humanist environment within which later debates have taken place. A sharper distinction between the (necessary) critique of anthropocentrism and the (equally necessary) renewal of humanist values is a main lesson that will inform the rest of the book.

After reassessing this debate on humanism, the book looks at seven writers with the help of which I try to unpack some of the key anthropological dimensions that will allow us to construe a universalistic principle of humanity. The 'anthropological question' is arguably not the central concern for any of these writers; their substantive contributions lie elsewhere and include of course a number of very different areas: from general epistemology to totalitarianism via ethical naturalism and economic sociology. Yet they all felt at some stage the need to articulate out explicitly the conceptions of the human with which they had been operating, more or less implicitly, up to that point. The order of the chapters is chronological and their focus is on one particular anthropological dimension. Chapter 2 focuses on Hannah Arendt's idea of self-transcendence as the human capacity with which we look at others and ourselves as if from an external position; self-transcendence as a form of withdrawal from the world but which is only possible to humans as eminently worldly beings. I reconstruct Arendt's distinction between the vita activa and the vita contemplativa and unpack their defining anthropological features as largely autonomous vis-à-vis particular historical conditions. Arendt's critique of Kant's utilitarianism then allows me to engage with her ideas of detached observation, cosmopolitan belonging and impartiality as well as to unpack what I contend is the idea of normative description that underpins her work. Chapter 3 looks at Talcott Parsons's idea of adaptation as the organic vortex that connects the various dimensions of human life to the natural environment. Parsons's late work on the human condition is of interest because there he explicitly pursues the kind of anthropocentric perspective that he had consistently rejected for three decades as he developed his AGIL (Adaptation; Goal Attainment; Integration; Latency) model: at stake here is Parsons's realisation that understanding the human can only be attempted from the inside out - it is a problem that matters only to humans themselves. Parsons's multilayered approach to the human also becomes apparent as we revisit his work on medicine and the sick role as well as his writings on the theory of generalised symbolic media. Chapter 4 discusses Hans Jonas's understanding of responsibility as a human relation that creates normative obligations as a fact of nature rather than a fact of reason. Parental selflessness becomes for Jonas the archetype for all kinds of responsibility: there are some things that we must do because only we can do them and it is this power differential 
that makes certain actions - e.g. looking after the planet - normatively obligatory. Jonas's original philosophical position takes the name of philosophical biology and can be described as a form of ethical naturalism: life and nature are his fundamental concepts and the normative standing of all living creatures can be ascertained both objectively - nature exists and is populated by living creatures - and subjectively - for these creatures, the continuation of their life is valuable in itself. The continuation of nature in general is a precondition for the continuation of human life, but neither can be taken for granted in our technological civilisation.

Chapter 5 reconstructs Jürgen Habermas's idea of language as the quintessentially social aspect of human life that is never altogether detached from its individual instantiation. Indeed, the reconstruction of Habermas's rendition of the linguistic turn and his project of a universal pragmatic lead us to reassess his original commitment to the idea of a communicative or interactive competence as the specifically human ability to make sense of the world, and interact efficiently in it, on the grounds of our ability for linguistic articulation. Habermas's explicit attempt to connect normative and descriptive propositions, his commitment to a universalistic orientation, and the fact that he is equally comfortable in sociological and philosophical debates, are all crucially important for my project. Chapter 6 then explores how Charles Taylor's idea of strong evaluations point to the human capacity for people to commit to those things that matter to them and which they can then use to organise the usually conflictive priorities that they experience in their lives. Taylor connects strong evaluations to the possibility of developing a more or less consistent idea of the self, the biographical articulation of a meaningful idea of who we are, which is in turn free from the individualistic fallacies that underpin most modern conceptions of identity. I will also explore Taylor's critique of modern proceduralism and comment on the, at times dogmatic and at times relativistic, implications of some of his propositions. Chapter 7 assesses Margaret Archer's notion of reflexivity as the key agential power through which people talk to themselves as they decide on their future courses of action. Archer's sociology of structure and agency matters because this experience of being partly free and partly constrained coincides with the ways in which people experience their own everyday circumstances. At the same time, there is her contention that agential powers are independent from structural ones and have causal powers that effectuate change in the social contexts within which they are necessarily exercised. As she builds on Marcel Mauss's distinction between a universal sense of self - that is to be found 
transhistorically and transculturally - and culturally specific concepts of the self, her principle of humanity explicitly engages with questions about physical adaptation, practical accomplishments and social worth. Chapter 8 reflects on Luc Boltanski's work on reproduction and abortion in order to assess the dual natural and social dimensions of the reproduction of life. The delimitation of a principle of humanity had been a major concern in Boltanski and Thévenot's (2006) earlier On Fustification, and this later work on abortion is explicitly set out as a test case for those earlier formulations. Boltanski will distinguish between 'flesh' and 'speech' as the organic and social dimensions of human life and will construe an interesting typology between authentic-, tumoral- and techno-foetuses depending on how the duality of speech and flesh plays out in society. Boltanski's own normative convictions are put to the test as he argues that, while abortions are legitimate, they cannot be construed as a value. The book closes with a short Epilogue that brings together its most relevant argumentative strands. ${ }^{21}$

In order to remain true to the general orientation of philosophical sociology, the book then includes three writers that we can call philosophers (Arendt, Jonas and Taylor), three self-declared sociologists (Parsons, Archer and Boltanski) and one writer who can be seen as either (Habermas). An enormous and usually extremely interesting debate surrounds the interpretation of every one of them - both in terms of the general orientation of their works and of several of their more specific contributions. Given that my goal is not to offer a comprehensive account of their approaches, for each chapter I have focused mostly on one or two texts where I think they succeed in making apparent their conception of the human. Some of my interpretations in this book may be seen as controversial and even partial, yet I expect each individual chapter to stand as a general argument on the anthropological dimension in question and as an essay on the respective writer's main ideas.

As I finished writing this book, it became increasingly apparent that most chapters do speak about the interplay between human embeddedness and imagination. While these two point in the same direction as traditional 'mind' and 'body' distinctions, I suggest that we see them as neither the end points of a continuum nor two sides of the same coin. They are rather the central relational properties of

${ }^{21}$ Readers familiar with contemporary social theory will notice that this organisation mirrors that of Hans Joas's The Genesis of Values (2000). While our positions and questions differ, I found his way of framing together philosophical and sociological concerns extremely helpful: each chapter is then both interpretative of a particular author and substantive with regard to a specific issue. 
our humanity: adaptation and responsibility are closer to embeddedness, self-transcendence and reflexivity are closer to imagination, while language, strong evaluations and the reproduction of life stand somewhat in between. It is this duality, and the difficult ways in which we continually re-elaborate it, the one that defines our common humanity. 
The origins of our contemporary posthumanist sensibility can be traced back to an exchange on humanism that involved Jean-Paul Sartre and Martin Heidegger in the mid 1940s. The philosophical question of humanism - what is it and whether it is an (un)tenable position - is of relevance because it is the one that grants legitimacy to the anthropological enquiry that I pursue in the rest of this book.

The first intervention on which I concentrate is Sartre's (2007) Existentialism Is a Humanism. A lecture that was originally delivered in October 1945, this was not a conventional academic talk. It was rather an intervention in a tense atmosphere and in front of an audience for whom philosophical questions were very much subordinated to political concerns. The second text is Heidegger's (1993a) Letter on Humanism. Written in the second half of 1946 and then reworked for publication the following year, the piece started life as a request to comment and expand on the theme of Sartre's lecture, which among other sources had drawn on Heidegger's pre-war writings. I contend that these two pieces have framed the terms within which questions about the status of the human - epistemologically, conceptually and normatively - are still being discussed in contemporary social science and philosophy. In order to highlight the ways in which the debate has been handed down to us, in the last section of the chapter, I also look at Jacques Derrida's (1982) essay The Ends of Man. First written in April 1968 and an early instalment in Derrida's long-term reassessment of Heidegger's work, this piece helps consolidate the critique of humanism as a 'by-default' position normative position. ${ }^{1}$ The chapter is therefore

\footnotetext{
${ }^{1}$ By the time of the publication of Derrida's text, the question of humanism had already become a major topic of political and philosophical debate in France - and not only within 'existentialist' circles. We can mention Louis Althusser's $(1969,2003)$ essays on humanism, Maurice Merleau-Ponty's $(1964,1969)$ texts Marxism and Humanism and Sense and Non-sense, the last chapter in Claude Levi-Strauss's (1970) The Savage Mind, the three essays that are reunited in Emmanuel Levinas's (2006) Humanism of the Other and, of course, Michel Foucault's (1997) chapter on the end of man in The Order of Things.
} 
devoted to analysing the ways in which humanism is being defined in these texts, how and why they distinguish between different forms of humanism, the relationships between humanism and anthropocentrism, and the limitations and contradictions of humanist positions. In fact, they all thought that some form of humanism must be favoured over others while rejecting openly anti-humanist arguments. ${ }^{2} \mathrm{I}$ am aware that, by concentrating on a handful of relatively short interventions by three writers who produced an impressive output, questions can be raised as to my ability to make a general assessment of their philosophies. I have therefore made use of additional texts in order to contextualise their wider positions and be able to comment on their intellectual orientation as a whole. Before we start, let me briefly say a few words about each of these pieces, their context, and how I have approached them.

Existentialism Is a Humanism remains Sartre's most popular piece. Even as its position within his larger body of work remains controversial, this lecture was key in establishing Sartre's reputation as France's leading public intellectual (Baehr 2015). One common view is to take Existentialism as an anomaly within Sartre's enormous literary production; here, the somewhat naive endorsement of humanism is seen as incompatible with, for instance, his earlier and philosophically more consistent use of 'nothingness'. Above all, the claim is that Sartre's genuine position would be more accurately represented in 'anti-humanist' passages in various novels, plays and indeed his extensive political writings for over thirty years. ${ }^{3}$ Not without merit, I think a major problem with this position is, quite simply, that there is not a single philosophical, let alone normative or political, doctrine to be derived from Sartre's works as a whole. This is clear in the major shifts to be

${ }^{2}$ From the literature that I mentioned in note 1, only Althusser (1969: 229) speaks favourably of anti-humanism in a strong sense, but even he qualifies this statement as a strictly philosophical (rather than an ethical) position: 'one can and must speak openly of Marx's theoretical anti-humanism, and see in this theoretical anti-humanism the absolute (negative) precondition of the (positive) knowledge of the human world itself, and of its practical transformation. It is impossible to know anything about men except on the absolute precondition that the philosophical (theoretical) myth of man is reduced to ashes'.

${ }^{3}$ See Craib (1976:3) for the argument on the exceptional position of the humanism lecture in Sartre's position and Lafarge (1970) for an anti-humanist interpretation of Sartre. Soper (1986: 23) and Feher (1991b: 567) highlight anti-humanist passages in Nausea, The Family Idiot and Saint Genet, whereas Aronson (1980: 169, 176) and Birchall (2004: 109-12) illustrate Sartre's erratic use of humanist tropes in various political contexts: for instance, in his oath of hatred against the bourgeoisie, his reluctance to repudiate Stalin's camps (or even to compare them with Hitler's camps), or in his uncritical support of anticolonial struggles. Incidentally, Craib (1976: 85-92, 215-28) uses the idea of philosophical sociology in his reassessment of the relationships between Sartre's philosophy and mainstream sociology. Our emphases are different, however, because Craib concentrates on what Sartre can offer as a critique of sociological functionalism, while I am interested in the way in which he articulates a humanist position. 
found between the 'phenomenological' sensibility of Being and Nothingness, that was first published in 1943, and the 'Marxist' outlook of Critique of Dialectical Reason (first published in 1960). But even if philosophical inconsistencies were possible to iron out, there is no continuity either in Sartre's highly volatile political commitments and commentary: the explicit apolitical tone of his work in the 1930s, his vocal anti-Stalinism after the Hitler-Stalin pact of 1939, the 'existentialist' moment during and immediately after the Second World War, his 'democratic socialism' period of 1946 and 1949, his rapprochement towards the French Communist Party and Soviet Russia between 1952 and 1956, his turn towards anti-colonialism in the 1960s plus his final Maoist period. ${ }^{4}$ Existentialism Is a Humanism is then as good a text as any other to speak about Sartre; what we have here is a rare text in which Sartre explicitly tries to articulate an optimistic type of politics that is informed by an ethical position (Aronson 1980: 288, Keefe 1988, Levy 2002: 41-57). Moreover, given that Sartre is there explicitly drawing on some of Heidegger's arguments in Being and Time, the piece also offers an excellent vantage point to compare and contrast their positions - if not to reassess Sartre's debt to Heidegger (Haar 1980, Theunissen 1985). Above everything else, Existentialism captures extremely well the fundamentals of the modern humanist sensibility in both its strengths and weaknesses.

Heidegger's Letter on Humanism is commonly seen as a transitional piece between his early publications before 1933 - most centrally Being and Time, which first appeared in 1927 - and those writings from after $1945 .^{5}$ Letter is said to be central to the 'turn' (die Kehre) of Heidegger's philosophy, in so far as it marks a shift from his original preoccupation with Dasein as a form of historical phenomenology to his more explicit reflections on being in general that rejected any anthropology as unwarranted metaphysics: Letter is fundamentally concerned with the need to subordinate questions about 'man' to questions about 'being'. Heidegger composed the text in 1946 as a request from French philosopher Jean Beaufret and, partially at least, in order to respond to Sartre's Existentialism lecture. Beaufret visited Heidegger for the first time in June 1944 and Letter is the most famous text of what effectively was a dialogue that lasted over thirty years and gave birth to a series of

${ }^{4}$ See Flynn (1988) for a summary account of Sartre's politics. Maybe unsurprisingly, those who read Sartre primarily as a philosopher show a greater need for finding unity within his work (Atwell 1986, Craib 1976, Lafarge 1970, Levy 2002, Weinstein and Weinstein 1971), whereas biographers are more reconciled to the fact that he was a deeply contradictory character and we should not try to find a single consistent perspective (Aronson 1980, Birchall 2004, Cohen-Solal 1991, Hayman 1986, Thody 1971).

${ }^{5}$ For general context, see Bourdieu (1991: 90-4), Hayman (1986: 283-4), Kleinberg (2003: 157-206), Rabinbach (2000: 97-128), Rockmore (1995: 98-103), Safranski (1998: 332-56). 
volumes, conferences and conversations. ${ }^{6}$ Biographically, Heidegger composed this text under difficult personal circumstances: he was living under French-administered territories and was right in the middle of the trials that were to decide on his academic future given his actions, on behalf of the Nazi regime, as rector of the University of Freiburg. Heidegger was not allowed to move freely, feared incarceration and confiscation of property, his pension rights were hanging in the balance and soon afterwards he was deprived of his teaching rights (he was to be reinstated to his teaching position in 1951). Perhaps we ought to read Letter mostly as a strategic attempt by Heidegger to look after himself during such an uncertain time: beyond the unusual emphasis he places in the 'correct' interpretation of Being and Time as a rejection of any form of anthropology, his criticism of Sartre has been seen as a bitter reaction to a meeting that failed to materialise at the time (their only meeting took place in 1952), the reference to Marx in the text has been read as a nod to Soviet authorities under which his son remained captive and, crucially, his critique of metaphysics has been interpreted as a strategy to distance himself from the Nazis. ${ }^{7}$ Below, I will concentrate on the philosophical reasons that make the critique of Sartre's humanism central to unpacking the normative implications of Heidegger's thinking. But given both the context and content of Letter, there is also a prima face case for discussing Heidegger's engagement with Nazism and its implications for his philosophical work. ${ }^{8}$

Finally, Derrida's piece The Ends of Man needs to be seen as part of a general effort among several notable French intellectuals in coming to terms with two general questions: first, the role of humanism in philosophy and, second, the troubling relationships between thinking and politics in Heidegger's work. ${ }^{9}$ This piece inaugurates a long-lasting engagement with Heidegger's philosophy and politics - one that looks increasingly one-sided and ultimately untenable. Having chosen Heidegger as the key motif for a paper on anthropology and humanism, Derrida endorses Heidegger's claim that conventional humanist

${ }^{6}$ These conversations are collected in Beaufret (1973a, 1973b, 1974, 1985).

${ }^{7}$ The 1952 meeting took place in Freiburg. Heidegger then travelled to Paris in 1955 for a conference that was organised by Beaufret but by then the politics of Heidegger's reception in France had had become too complicated and Sartre did not take part in that conference.

${ }^{8}$ It is still common, of course, to read Sartre and Heidegger as existentialist thinkers who sit together as travelling companions (Blackham 1961, Marino 2004, Theunissen 1985). Here, however, I am interested in their different conceptions of humanism. See Janicaud (1996: 41-9) for a comparison between Sartre and Heidegger's existentialism where their main difference lies in the former's interest in politics and the latter's at least explicit apoliticism.

${ }^{9}$ See note 1, and also Bourdieu (1991), Deleuze and Guattari (1995) and Lyotard (1990). 
perspectives are fundamentally flawed. Derrida then tries to work out the implications of Heidegger's 'higher' form of humanism and, in so doing, he elaborates on the philosophical position of the idea of 'man'. Writing in 1968 , Derrida makes a great deal of the political circumstances surrounding his text at the same time as he wholly avoids those that Heidegger had to confront while preparing his own. As he tries to isolate politics from the rest of Heidegger's philosophy, Derrida then mounts a highly sophisticated, though to my mind unsuccessful rescue operation of Heidegger's humanism - the consequences of which are still very much present with us (Wood 1993).

\section{I}

Existentialism Is a Humanism is primarily devoted to the delimitation of Sartre's branch of existentialism and its ability to make a practical contribution to France and Europe's reconstruction immediately after the Second World War. Humanism was neither a unified outlook nor carried unqualified support at that time, but Sartre's first aim was to reject the notion that his philosophy, the idea of nothingness included, was in fact a form of anti-humanism. Sartre's idea of nothingness works as a form of immanent critique of 'human reality' so that we are able to creatively imagine a different world. Far from being the source of philosophical nihilism, Sartre contends that his idea of nothingness is centrally defined through its relation to human freedom: '[f]reedom is precisely the nothingness which is made-to-be at the heart of man and which forces human-reality to make itself instead of to be' (Sartre 1957: 440). Humanism is the ethical point of reference for this lecture because it accounts for the practical and ultimately political justifications of his philosophy.

In Existentialism, Sartre is at pains to reject the common charge against the individualistic bias of his philosophy. This criticism centred on two main issues: first, and this is the core of Heidegger's critique later on, Sartre's insistence in subjectivity is interpreted as a dogmatic resistance to break free from Cartesianism and its anthropocentrism; second, as advanced primarily by Merleau-Ponty, Sartre's inability to conceptualise classes as collective actors in their own right (Aronson 1980: 243-86, Soper 1986: 60-74). Communists and Catholics shared a common target in criticising the 'subjectivism' that they regarded as central to existentialist philosophy, but this is a gambit that Sartre (2007: 20) readily accepts: 'subjectivity must be our point of departure' because, rightly understood, subjectivity implies rather than negates our relationships with others. The problem, Sartre contends, lies in the fact that critics have misunderstood what subjectivity actually is 
and existentialist philosophy needs to put them right: communists reduce subjectivity merely to its individualistic connotations, while Catholics see subjectivity as just another name for historicism, cultural relativism or even nihilism. Against both, Sartre argues that individuality is inseparable from our relationships with the human species as a whole: 'man finds himself in a complex social situation in which he himself is committed and by his choices commits all mankind' (2007: 45). His notion of subjectivity is not seen as exclusively individual but presupposes sociality and collective action. Humans, Sartre contends, are immediately thrust in a world of 'intersubjectivity' (2007: 42). Writing in the decisionist language of 'choices', Sartre defends the idea that individualism is a collective achievement that finds its normative purchase in the idea of freedom: 'I cannot discover any truth whatsoever about myself except through the mediation of another. The other is essential to my existence ... my intimate discovery of myself is at the same time a revelation of the other as a freedom that confronts my own' (2007: 41-2, my italics). Quite rightly, his argument is that no form of modern thinking is worth its salt if it fails to uphold to a strong idea of subjectivity. Indeed, Sartre (1995: 82) correctly warns against the possible essentialism of 'group error' that thinks it can do without subjectivity and individuality: this is what allows some to speak of 'the Germans', 'the French' and indeed 'the Jews' as homogeneous units. ${ }^{10}$ With regard to the objection of relativism, Sartre discusses it on two fronts. On the one hand, he rejects any 'reference to a given and immutable human nature' and speaks rather of 'the human condition' (2007: 29, 42). Values do not derive their authority from human nature nor can they appeal to any form of nonhuman authority: human freedom alone is 'the foundation of all values' (2007: 48). ${ }^{11}$ On the other hand, Sartre needs to offer an alternative to secure the foundation of values in order to overcome relativism. This, he again contends, can only take the form of an idea of human freedom that becomes universally binding for humanity as a whole. A dialectics between individual freedom and the general freedom of the human species frames his approach: we 'will freedom for freedom's sake through our individual circumstances. And in thus willing freedom, we discover that it depends entirely on the freedom of others, and that the freedom of others depends on our own' (2007: 48). ${ }^{12}$

${ }^{10}$ As we have mentioned already, Sartre did not live up to his own critical stance against group error in his political writings. See note 3.

11 An argument that we will also encounter in Chapter 2 on Hannah Arendt, it remains an open question whether this claim to have replaced an 'essential' idea of human nature with a 'historical' notion of 'human condition' proves ultimately meaningful.

12 Iris Murdoch (1976: 34) emphasises instead the non-conformist aspect of Sartre's idea of individuality: '[ $\mathrm{i}] \mathrm{t}$ is on the lonely awareness of the individual and not on the individual's 
Having rejected the accusations of anti-humanism at the very start of the lecture, Sartre comes to the question of what humanism actually is only towards the end of his piece. There, he argues that existentialism and humanism share a common origin that is to be traced back to the enlightenment in the eighteenth century; more precisely, they share the realisation that, now that religious justifications of moral values have become problematic, only human beings can create values for themselves: indeed, they cannot but do so. Sartre then distinguishes between two different meanings of the term humanism - and this is an analytical move that we will find repeated countless times in the literature. There is a first type of humanism, which Sartre rejects, because it is 'a theory that takes man as an end and as the supreme value' (2007: 51). This form of humanism takes pride in the collective accomplishments of the human species - for instance, its legal institutions, works of art or technological innovations - and then invites individual human beings to partake in this admiration for what the best among humans have been able to achieve through the ages. Sartre describes this humanism as a 'cult of humanity' and rejects it as a form of essentialism and reification: one can 'never consider man as an end, because man is constantly in the making' (2007: 52). An argument that we will also find in Chapter 2, at least part of the question is whether, by claiming that we treat humans only as ends and never as means, the Kantian tradition has implicitly adopted within its moral thinking the utilitarianism that it thought to leave behind. Sartre rejects here a notion of the human that is based on a fixed, ahistorical essence: any idea that points towards the finitude of man can only lead to its hypostatisation and, eventually, to its devaluation - and this is again something that we will encounter below as we assess the tension between telos and finis in Derrida's argument. But arguably the most consequential implication of this argument connects us to the core of Heidegger's critique of humanism. While Sartre rejects this type of humanism because of its elitism, elitism is a key theme in Heidegger's recovery of humanism. To Sartre, the glorification of the accomplishments of the few cannot be used to justify passive admiration on behalf of the many because this opens the door for the ultimate devaluation of those who are not deemed capable of reaching such heights. Sartre rejects this false 'Comteian humanism' because it 'leads ultimately ... to Fascism' (2007: 52).

Having rejected spurious ideas of human essence that can be turned into objects of demonic worship as well as ideas of the genius that elevate the chosen few over the many, Sartre now delineates the humanism to

integration with his society that his attention centres. In Sartre's world rational awareness is in inverse ratio to social integration; as soon as his characters begin to reflect they detach themselves from their background' (my italics). See also Chapters 2 and 7. 
which he is positively committed. This he defines through an idea of human transcendence: 'man is always outside of himself, and it is in projecting and losing himself beyond himself that man is realised ... it is in pursuing transcendental goals that he is able to exist' (2007: 52). This appeal to transcendental relations and goals implies no deity or metaphysical cosmology, says Sartre, but points instead to an idea of 'liberation' that is defined in terms of human beings' own internal transcendence: 'man is nothing other than what he makes of himself ... there is no other legislator than himself' (2007: 22, 53). Sartre's humanism centres on the human capacity for self-legislation: a genuinely human life is above all based on this creative capacity, and thus the idea of imagination becomes a fundamental anthropological feature for Sartre. Sartre contends that this type of humanism demands a form of realism that gives humans no place to hide, for instance, from their own selfish motivations and ideological delusions: existentialism is a humanism because it demands that humans take full responsibility for who they are, for the way they behave and for the commitments they make. Existentialism makes it clear that the price to be paid for the realisation of this responsibility is a (Kierkegaardian) 'anguish' for the consequences of our decisions and also a (Heideggerian) sense of 'abandonment' (2007: 25-7, 34). Sartre's humanism then favours creativity, imagination and self-transcendence while it accepts the existential responsibility that comes with having to make these choices. ${ }^{13}$

In terms of his debt to Heidegger, there is no question that Sartre felt a strong affinity with some of his theses and, above all, he was taken by Heidegger's ability to offer a new language for a world that was undergoing dramatic change. ${ }^{14}$ Heidegger figures centrally in Being and Nothingness and, in the Existentialism lecture, Sartre echoes Heidegger's call for commitment, seizing the truth, and decision (2007: 36, 40). Crucially, Sartre resorts to the French rendition of Dasein as 'human existence' which, as we will see below, was the standard anthropological reading of Heidegger's Being and Time that was prevalent in France at the

${ }^{13}$ See Ishiguro (1971) for an account of Sartre's idea of imagination and Keefe (1988: 84-5) for an assessment of the Kantian root of Sartre's position in the Existentialism lecture. 'Imagination' vs 'thrownness' is the way in which Peter Gordon (2012: 136-214) has reconstructed the radically different anthropologies that underpin Ernst Cassirer and Martin Heidegger's positions during their Davos debate in 1929. If that is the case, then although in language Sartre seems closer to Heidegger, his egalitarian idea of freedom moves him closer to Cassirer's neo-Kantianism. See Taylor (1985a: 29-35) for a critique of Sartre's language of 'radical choices' - to which he opposes his own idea of strong evaluations. I come back to this in Chapter 6.

${ }^{14}$ In relation to Nausea, Ronald Hayman makes the point that I think holds more generally: 'Sartre was not merely popularizing the ideas of Heidegger, he was dramatizing them' (1986: 99, my italics; see also 187-9). 
time (this is the very interpretation that Heidegger will forcefully reject a year later in Letter). Sartre's interpretation of Heidegger is that of a humanist philosophy and is based on the ambiguities that can be found in Being and Time with regard to the relationships between man, being and Dasein: to this generation of writers, Heidegger was not and could not have been a Nazi sympathiser because he was an existentialist. Crucially, however, as we will see in detail below, Letter makes impossible to continue reading Heidegger along rationalist, egalitarian or conventionally humanist lines: Heidegger says no to an anthropological reading of his earlier work and rejects the idea that his branch of existentialism belongs to the Western philosophical canon that culminates in the Enlightenment.

In fact, Heidegger's relationship with Nazism was to cause problems to Sartre's political credentials before, during and indeed also after the war (Cohen-Solal 1991: 141-2, 187, 194, 221). On occasions, Sartre saw this as a strategy of delegitimisation by association and resorted to what have since become common counter-arguments: the idea that there was no systematic link between Heidegger's politics and his philosophy and also that, although the man himself may have been a coward as he caved into Nazi pressures (not a minor charge for a 'decisionist' philosopher), personal traits are of no genuine philosophical implication. Sartre was not alone in failing to appreciate the connections between the irrationalism of Heidegger's philosophy and the authoritarianism of his politics - not least as he knew about Heidegger's politics as early as 1934 (Birchall 2004: 19-22). To his credit, on the other hand, Sartre did not avoid the issue and played a key role in setting up a first wave of debate on the relationship between Heidegger's philosophy and politics. Les Temps Modernes, the journal Sartre co-founded and co-edited, published among his early issues of 1946 and 1947 several articles that explicitly addressed the question of Heidegger's politics. ${ }^{15}$

In Existentialism, Sartre used Heidegger in order to criticise lofty ideals that remained separated out from actual historical reality: 'I cannot count on men whom I do not know based on faith in the goodness of humanity' (2007: 35). Heidegger's key term 'authenticity' appears later in the text, twice on the same page, and is referred to positively because it points to the notion of total freedom that existentialism favours (2007: 49). And indeed Sartre's (2007: 20) famous dictum that existence precedes essence is taken literally from Heidegger's (1997: 68) preliminary delimitation of Dasein in Being and Time. ${ }^{16}$ But as one reads through the final sections of

${ }^{15}$ The best known of these articles is Karl Löwith's piece on the political implications of Heidegger's ontology. There are two versions of this piece in English, see Karl Löwith (1991, 1995: 211-25).

${ }^{16}$ In Letter, however, Heidegger (1993a: 232-7) will judge this interpretation wholly mistaken and even alien to his intentions. 
Being and Nothingness that concentrate on the positive articulation of an idea of freedom, it becomes increasingly clear that there are also major differences between both projects. There, Sartre claims that the major shortcoming of Heidegger's work lies in the fact Being and Time fundamentally lacks an ethical dimension. Sartre had dressed his argument up in Heideggerian rhetoric but his ultimate point is very much the opposite of Heidegger's: 'freedom is not a being; it is the being of man' (Sartre 1957: 441). Sartre's idea of freedom is not devoid of difficulties, not least as he insists that even under extreme duress the individual remains free to choose. And Sartre himself conceded that his anti-establishment sensibility during the war allowed for 'a vague nostalgia of fascism' in some of his own writing. But it is the constant return to an egalitarian idea of freedom that led Sartre to 'employ Heidegger's work against fascist totalitarianism' (Kleinberg 2003: 132-3, my italics).

Another way of making a similar argument would be to show that, although the decisionist language that favours commitment over justification is not difficult to find in Existentialism, Sartre never suggests that decisions are to be taken beyond the realm of rational argument. For instance, there is more than a Kantian echo in Sartre's argument that the idea of the individual cannot be understood outside notions of human freedom and responsibility. It is on this basis that Sartre then connects the particular and the universal: human responsibility is 'much greater than we might have supposed, because it concerns all mankind ... In choosing myself, I choose man' (2007: 24-5). His resort to the idea of freedom is a way to come out of moral paralysis and the argument here depends on an insight that is altogether alien to Heidegger; namely, an idea of freedom that is fundamentally connected to the Kantian dictum that 'freedom wills itself and the freedom of others' (2007: 49). In so far as an idea of human dignity underpins the existentialism which he advocates, Sartre's humanism is fundamentally tied to an anthropocentric perspective: 'man is nothing other than what he makes of himself' (2007: 22). Kant is criticised because of the risk of essentialising human ends that we discussed above, and also because his ethical principles are 'too abstract' and therefore 'fail to define action'; and yet Sartre commits to the universalistic and egalitarian thrust of this idea of freedom (2007: 49) ${ }^{17}$ For instance, Sartre's universalistic commitments allow him to advance a strong notion of universal, rather than sociocultural, empathy:

${ }^{17}$ Kantian themes of this kind are also central to Sartre's argument on the liberating role of literature in his What Is Literature? (see Sartre 1978, Aronson 1980: 149-50). Quite rightly, Soper (1986: 61) contends that Sartre could not have endorsed Heidegger's idea that being and man do look for each other because this would have undermined any fullyfledged notion of human freedom. See Sartre (1957: 433-81). 
$[\mathrm{H}]$ uman universality exists, but it is not a given; it is in perpetual construction ... I construct it by understanding every other man's project, regardless of the era in which he lives ... The fundamental aim of existentialism is to reveal the link between the absolute character of the free commitment, by which every man realizes himself in realizing a type of humanity - and a commitment that is always understandable, by anyone in any era - and the relativity of the culture ensemble that may result from such a choice. (2007: 43)

An idea of universal empathy is something that ought to be refined and retained; it is essential if the social and political sciences are to remain open to genuine sociocultural and normative dialogue. ${ }^{18}$ The idea of universal empathy works because, as members of the same human species, there are some needs and capabilities that apply to us all: we can and indeed do experience inter- and trans-cultural sympathy on such key experiences as grief, pain, love, fear, admiration and happiness. This universalism is incompatible with elitism or cultural essentialism: the idea of human dignity only makes sense on the basis of a strong commitment to the egalitarianism of a universalistic principle of humanity.

A theme that will accompany us throughout this book, Sartre does not distinguish clearly between normative ideas of humanity - the humanism that sees humans as possessors of a fundamental dignity - and cognitive notions of human authorship, that is, the anthropocentrism that focuses on humans' mastery of the world. Because humans are not surrounded only by an environment that is made by humans themselves, Sartre is wrong when he claims that we are nothing but what we make of ourselves: we of course live as members of the natural world, we are in possession of a human body and there are social, cultural and technological structures that present themselves as alien to humans themselves. The challenge that remains is whether and how Sartre's humanism can be separated out from the more contentious implications of his anthropocentrism; namely, whether humans are to be treated as the ultimate standard against which everything in the world is to be measured. Indeed, Sartre elides the principle of human authorship, the idea of universal empathy and the anthropocentric notion of humans as the ultimate standard: '[e]verything happens to every man as if the entire human race were staring at him and measuring itself by what he does' (2007: 26, my italics). We rather need a clear separation between humanism and anthropocentrism, between the key normative idea of human dignity and an

${ }^{18}$ Sartre makes this point explicitly as a critique of Eurocentrism when he refers to our mutual understanding with a 'Chinese, Indian or black African: There is universality in every project, inasmuch as any man is capable of understanding any human project' (1978: 43). I have argued elsewhere that this is a key idea that transpires from the best tradition of sociology and social theory (Chernilo 2007a: 25-32, 2014). 
inflated notion of human authorship. On the one hand, the proposition on the intrinsic value of human beings qua human beings underpins our understanding that social and cultural institutions are the product of human action itself; on the other hand, we should not translate this into an anthropocentric proposition that is deeply mistaken: humans are not the measure of all things, the cosmos is not organised for the benefit of humans and the natural environment is self-sustaining vis-à-vis human intervention. ${ }^{19}$ We can follow neither Sartre's uncritical anthropocentrism nor Heidegger's rejection of humanism here: instead, we need to separate out the normative value of humanism from the reductionist implications of anthropocentrism; indeed we then require the former to inform our critique of the latter.

Another critical feature of Existentialism is whether humanism necessarily becomes a form of foundationalism and we have seen that Sartre consistently tries to unite opposites: 'there is no difference between free being - being as a project, being as existence choosing its essence - and absolute being. Nor is there any difference between being as an absolute temporarily localized - that is, localized in history - and universally intelligible being' (Sartre 2007: 43-4). At stake here is a logic of reconciliation that systematically tries to bring together the individual and the collective, the subjective and the objective, the immanent and the transcendental, the historical and the general, the particular and the universal. ${ }^{20}$ In Sartre, humanism becomes a form of foundationalism because our approval or rejection of it is ultimately made to depend on a question of principle: ontologically, whether reconciliation is an adequate doctrine of being in general (and of human beings in particular); historically, whether reconciliation awaits at the end of history (an idea of progress that helps us explain temporary distortions, deformations and even aberrations); normatively, whether reconciliation is the highest human value of them all. Sartre's commitment to this logic of reconciliation makes his ultimate position untenable but the argument can be made that this is already a result of his previous conflation between humanism and anthropocentrism. Indeed,

${ }^{19}$ First published in 1938, Gaston Bachelard's (2002) La Formation de L'Esprit Scientifique suggests that anthropocentrism was one key 'epistemological obstacle' that had to be overcome for modern science to emerge: the universe neither exists nor works for human benefit. Foucault, Derrida and Althusser all figure among Bachelard's former students and to that extent we may interpret their critique of humanism as an expression of this rejection of anthropocentrism. In sociology, this argument has been taken up by Niklas Luhmann's (2012: 5-13) rendition of our discipline's own epistemological obstacles (see Mascareño and Chernilo 2009 for further discussion). As I will argue at the end of this chapter, humanism and anthropocentrism need to be clearly distinguished. See also the book's Epilogue.

${ }^{20}$ On this, see also Michael Walzer's (1995: xvii-xx) critique of Sartre in Anti-Semite and few. 
as we saw in the Introduction, most contemporary rejections of conventional humanism seem to hang on this weakness as they elaborate on the dystopian prevalence of symbolic and material violence in modern times. But what we really need is to question the logic that makes it difficult to distinguish humanism from anthropocentrism. It is the dual charge of subjectivism and foundationalism that mortally wounds Sartre's project: but while the former ought to be retained on the humanist grounds of an egalitarian conception of freedom, the latter is to be rejected as the arrogant expression of our specie's exclusive concern with ourselves.

Let me conclude this section by briefly mentioning three topics that shall prove central to later debates on humanism but which do not figure centrally in Sartre's argument. First, we have seen that Sartre's position is wholeheartedly atheistic. But to the extent that humanism centres on the question of human dignity, it can easily abandon the anthropocentric requirement of human authorship and be made compatible with various forms of religious arguments. Somewhat paradoxically, then, humanism has become increasingly close to religious convictions about the 'sanctity' of human life. Second, Sartre does not really discuss questions of inhumanity and even anti-humanism; there is no real engagement with the argument that social practices, themselves a product of human action, may be constitutively unable to bring about the reconciliatory motifs of humanism (Lyotard 1993). The third and final theme that does not appear in the text, but which figures highly in subsequent discussions, is that of technology. From the alleged neutrality of modern technology to its being a source of alienation, technological innovations matter because they redefine our humanity by interfering directly on the relationships between culture and nature, between humanity and society. Whether this is a challenge to the logic of reconciliation of humanism, or it is rather that technologies themselves become an instrument in renewing our hopes for future human reconciliation, remains open to debate. Either way, questions about technology continue to inform anthropological debates that seek to understand the human.

\section{II}

We have said that Heidegger wrote his Letter on Humanism soon after the end of the war and as a request from French philosopher, Jean Beaufret. Living under French-occupied Germany and unsure about his future, Heidegger had every reason to welcome various exchanges with French 
officials and philosophers at the time. Letter was indeed first published in French in $1947 .^{21}$

American philosopher Tom Rockmore has devoted several works to explore the history of Heidegger's reception in France (1992, 1995, 2009). He argues that we see its development in three waves. A first, humanist, interpretation was advanced by Alexandre Koyré, Alexander Kojeve and Sartre himself in the 1930s and 1940s. As apparent in our discussion in the previous section, Heidegger was being read here as fully belonging in the humanist tradition; he was a philosopher who sought to rejuvenate the venerable humanist tradition that in the meantime had lost touch with the realities of modern society. Crucially, Heidegger's original approach was being interpreted as an attempt to develop a genuine philosophical anthropology - not least through the rendition of his notion of Dasein as human reality. A second wave of reception developed between the late 1940 s and the mid 1980 s. $^{22}$ Originally advanced by Jean Beaufret and eventually by such leadings figures as Derrida himself, Letter becomes the key text that allowed them to directly challenge this anthropological reading. In their view, the question was to show that Heidegger's philosophy sought to overcome traditional humanism and, without turning into an apology for anti-humanism, the project was to offer a new, allegedly higher, version of humanism itself. Also, and given that details about Heidegger's political past continued to emerge throughout this period, this second wave of reception had to face the question of the relationships between politics and philosophy in Heidegger's work. The standard view was here that the two had to be separated out, and several claims were put forward to explain away their interconnections: Heidegger's actions as rector were a strategic move to protect academic freedoms and the autonomy of the university against Nazi intervention; his endorsement of Nazism was genuine but short-lived, and it expressed nothing different from the various forms of 'radicalism' to which scholars of all persuasions felt attraction during the convoluted politics of the twentieth century; his behaviour was a mere expression of political immaturity, naivety or even cowardice for a philosopher who had until then remained wholly apolitical. Ultimately, however, it became impossible to deny that his politics had some connection to his philosophy,

21 The main instigator of this rapprochement with Heidegger was the French military attaché Frédéric de Towarnicki, who tried but failed to secure a visa for Sartre and de Beauvoir to visit Heidegger in 1946. It is in this context that Jean Beaufret came into contact with Towarnicki and was eventually allowed to visit Heidegger, for the first time, even before the end of the war (Kleinberg 2003: 162-8).

${ }^{22}$ Interestingly, already in 1959 Habermas had argued that Heidegger's influence in Germany was a 'reimport' from France (1985: 57). On general context, see also Cohen (2006) and Sluga (1993). 
but the argument remained that this was ultimately inconsequential at the most fundamental intellectual level. ${ }^{23}$

A third wave of debate started in the 1980s and was triggered by the publication of Víctor Farías's (1989) book Heidegger and Nazism. The merits of this publication have been the subject of heated discussion, but since its appearance it has become necessary to engage explicitly with the politics of Heidegger's work as part of a general reassessment of his philosophy. For a sociological audience, Pierre Bourdieu's (1991) book on Heidegger offers a good case in point. First published in 1975, Bourdieu reworked his text and republished it in 1988 in the context of the contentious reception of Farías's work. Bourdieu systematically applies his concepts of field, habitus and symbolic violence in order to explain Heidegger's philosophical and political outlook. For instance, Bourdieu treats Letter as a paradigmatic case in which an author seeks to authoritatively adjudicate between competing readings of his previous work in order to impose the canon that is to rule over future interpretations (1991: 90-4). Letter was expected to make it impossible to continue reading Heidegger alongside rationalist or humanist lines because Heidegger blames them for the rise of Nazism: Heidegger's critique of humanism is the critique of modern anthropocentrism gone mad. Bourdieu also reflects on a certain isomorphism between the philosophical and the political fields and shows that Heidegger sought to establish a new path in both arenas: his philosophy sought to offer a third way in between Marxism and neo-Kantianism as much as his political endorsement of Nazism is to be seen as a third way in between the Soviet revolution and bourgeois democracy (1991: 57-67). ${ }^{24}$

Beyond Bourdieu, the net result of this third wave of reception is that it is no longer tenable to suggest that we are only talking of a short period of time in which Heidegger was caught up in the irrational mood of its time or that, because he soon realised that it was all a terrible mistake, there is nothing philosophically consequential about his actions during the 1930s. The publication of a recent book by Emmanuel Faye (2009) has in fact led Rockmore to suggest that we have entered a fourth wave in which Heidegger's political Nazism needs to be seen as integral to his philosophy. ${ }^{25}$ Faye's research

${ }^{23}$ Apart from Derrida's position, these arguments can also be found in Deleuze and Guattari (1995), Gadamer (1992) and Lyotard (1990). See Grassi (1983, 1988) for a general discussion of Heidegger's understanding of humanism.

${ }^{24}$ Far more problematic, however, is the sociological reductionism through which Bourdieu explains the differences between Sartre and Heidegger in relation to differences in their lower middle-class habitus (1991: 131).

${ }^{25}$ In this context, Rockmore (2009: x-xiii) also comments on new evidence that connects Beaufret with the French branch of Holocaust deniers. On this periodisation of Heidegger's reception in France, see also Kleinberg (2003: 205). 
demonstrates that Heidegger showed genuine zeal and initiative in his actions as rector, that he wrote and lectured extensively on Fascism and Nazi ideology both before and after 1933, and that he explicitly sought to connect philosophical reflection and political action throughout the 1930s and 1940s. Faye's claim is that Heidegger was both a highly talented and a wholly unreconstructed organic intellectual who openly endorsed Fascism since the early 1920s: this political commitment pre-dates the publication of Being and Time. This book then needs to be reread as the philosophical articulation of his own version of right-wing conservatism that belongs to the intellectual anti-intellectualism that was already popular in Germany at the time - what Adorno (2003: 1, 43) later called the jargon of authenticity. The ultimate philosophical scandal is not Heidegger's Nazi sympathies but his continuous lack of reflection on the victims of the war and of Nazi policies (Caputo 1992). ${ }^{26}$

Credit must then be given to Karl Löwith, who saw it all quite clearly already in 1946: while Heidegger's political endorsement of Nazism in particular was contingent upon its success as a mass movement in 1920 s Germany, Heidegger's philosophical edifice was explicitly in tune with the idea that, given the general decay of contemporary society, there was a demand to seize any opportunity for historical renewal: elitism, irrationalism, authenticity, historicity, collectivism and resoluteness are all central to Heidegger's work both politically and philosophically: 'Heidegger did not "misunderstand himself" when he supported Hitler; on the contrary, anyone who did not comprehend how he could do this did not understand him' (Löwith 1995: 223). Heidegger's critique of humanism then matters because he explicitly rejected any form of universalistic orientation in the form of egalitarianism, rationalism or subjectivity. As we will see below, Heidegger inaugurates an argument that is now ubiquitous in the literature: he blames the humanism of Western metaphysics for the contemporary crises of modern society.

Philosophically, as said, Letter was meant to be both a clarification of Heidegger's own thinking with regard to the anthropological interpretation of Being and Time and a rejoinder to Sartre's Existentialism lecture

${ }^{26}$ On Heidegger's early enthusiasm for the regime and its wars, see Faye (2009), Safranski (1998) and Losurdo (1992). By the mid 1950s Heidegger could still pen that, apart from Germany now being 'cut in two', the Second World War 'has decided nothing' in terms of 'man's essential fate on this earth'; rather the opposite, 'only the things that have remained undecided stand out somewhat more clearly' (2004: 66, my italics). Heidegger never really accounted for his actions at the time - let alone apologised for them. The interview Heidegger gave to Der Spiegel in 1966, and that was published posthumously in 1976, is usually cited as the one instance in which this silence is broken - although it produced no hint of self-criticism and the only embarrassment that is forthcoming belongs to the interviewers as they apologised to Heidegger for raising uncomfortable questions (1991b). The theme of Heidegger's lack of apology is analysed in Kisiel (1992). See also Chapter 2. 
that had just been published. Maybe unsurprisingly, Heidegger challenges the terms of the invitation to reflect on humanism because the very question already 'contains an admission that this word has lost its meaning' (1993a: 247). Early in the text, Heidegger makes clear the key move that inspires what will follow: 'is the damage caused by all such terms still not sufficiently obvious?' (1993a: 219, my italics): Humanism is dead but rather than feeling sorry for this loss we must rather engage in a 'radical' reinterpretation of its presuppositions and implications.

Similar to what Sartre does in Existentialism, Letter also offers first a critique and then a redefinition of humanism. Heidegger shows no mercy towards Sartre, however, who is criticised for having shown no understanding of Heidegger's genuine position. Sartre's philosophy is depicted as fully belonging to the kind of metaphysics that must be rejected and abandoned, and the damage of humanism is defined by its endorsement of the 'metaphysics of subjectivity' that defines modern times (1993a: 222-37). Humanism is subjectivism because it focuses on the narrow, particularistic point of view of man and, in so doing, it renounces to grasp the ultimate essence of being: humanism sides with the subjectivity with the anthropos and, in so doing, it rejects the pursuit of the fundamental determinations of being in general. ${ }^{27}$ Heidegger accepts that ideas of humanism vary depending on how claims for it are introduced, so that different forms of humanism will develop based on how they justify a 'conception of the "freedom" and "nature" of man' (1993a: 225). Humanism is not only a form of subjectivism but also a form of relativism and even nihilism because it leaves humans 'free' to do as they please; Heidegger rejects humanism because it encapsulates everything that in his view is wrong in Western metaphysics from Plato to Nietzsche (Löwith 1995: 36, 55-60, 97). ${ }^{28}$

Heidegger argues that if we accept his thesis that we need to depart from humanism, we need also to accept its consequences and reject also all forms of anthropocentrism. Modern society has however moved in the opposite direction and is ever more dependent on the idea that 'civilization and culture' are only 'vindicated ... for the sake of man' (1993a: 233). Humanism remains the dogmatic expression of Western metaphysics after all its previous idols have gone, and Heidegger compares Marx's materialist humanism, Sartre's existentialist humanism and Christianity's religious humanism in order to show that, although they are different in

${ }^{27}$ Given that I am trying to demystify its irrationalism and mysticism, I will not follow the convention of writing 'Being' with capital B. I will do so only for direct quotations.

${ }^{28}$ Levinas (2006: 47) is right when he claims that, in Heidegger, the critique of humanism and metaphysics are one and the same: '[e]very humanism is either grounded in metaphysics or is itself made to be the ground for one'. 
'purpose and principle', this makes little substantive difference because they are all equally based on subjectivism, on the one hand, and on a reductionist account of the human, on the other. All these humanisms are problematic because they share the view 'that the humanitas of homo humanus is determined with regard to an already established interpretation of nature, history, world' (1993a: 225). At face value at least, Heidegger seems to be aiming at a certain decentring of humanism, something we may describe as an anti-anthropocentric form of humanism:

what is peculiar to all metaphysics, specifically with respect to the way the essence of man is determined, is that it is "humanistic". Accordingly, every humanism remains metaphysical. In defining the humanity of man humanism not only does not ask about the relation of Being to the essence of man; because of its metaphysical origin humanism even impedes the question by neither recognizing it nor understanding it. (1993a: 226, my italics)

In Heidegger's argument, then, the failure of humanism is threefold. First, instead of a strong sense of the human, humanism offers nothing other than subjectivism and nihilism. Humanism is unable to live up to its promises; indeed, it is responsible for the irresponsibility that ensues in endorsing human self-determination. Second, this subjectivism claims to be self-positing but requires, instead, the external justifications that nature, history or god can provide. Humanism fails to deliver on its most essential commitments of making human life dependent on the autonomy of the will. Third, this subjectivism makes it impossible to reach an understanding of being as the genuine source of dignity of all forms of human experience. The subjectivist metaphysics of humanism presupposes rather than genuinely explores where the humanity of human beings ultimately lies and, as it blocks our vision of ultimate questions, these can only reemerge through a radical critique of humanism itself. In dogmatically asserting a metaphysical idea of man, humanism contributes to the devaluation of humanity and, because it concentrates on the subjectivity of the anthropos, it becomes responsible for humans' inability to see beyond themselves.

Heidegger takes issue with the alleged devaluation of the human that was now prevalent in philosophical anthropology: true humanism must stop looking at what humans share with other living species as much as it must stop looking inwardly in the direction of subjectivity itself; rather, it ought to concentrate on what lies above traditional ideas of humanity. Philosophical anthropology, as the latest expression of Western metaphysics, is deeply flawed because it 'thinks of man on the basis of animalitas and does not think in the direction of humanitas. Metaphysics closes itself to the simple essential fact that man essentially occurs only in his essence, where 
he is claimed by Being' (1993a: 227, underlining mine). Philosophical anthropology may claim to be rational, philosophically informed and scientifically sound and yet it fails because it continues to define the human the wrong way round:

All anthropology continues to be dominated by the idea that man is an organism. Philosophical anthropology as well as scientific anthropology will not use man's essential nature as the starting point for their definition of man.

If we are to think of man not as an organism but a human being, we must first give attention to the fact that man is that being who has his being by pointing to what is ... Man is the being who is in that he points toward "Being," and who can be himself only as he always and everywhere refers himself to what is. (2004: 148-9)

The humanity of human beings is to be defined through an essential notion of being because only thus may man be able to raise genuinely fundamental questions. Western metaphysics fails because it does not 'ask in what way the essence of man belongs to the truth of Being' (1993a: 226, my italics).

In Karl Löwith's (1995: 39-48, 56-63, 78) interpretation, it is this question of the relationship between humans and being that is the fundamental question of Heidegger's philosophy in its entirety. As we just saw, the predominant interpretation in France at the time of publication of Letter, the one on which Sartre draws, was to read Heidegger's argument as supportive of anthropological humanism. But this is precisely the interpretation that Heidegger now explicitly dismisses: if in Being and Time the idea of Dasein could be reconstructed as the mediating point at which man and being relate to one and another - Dasein allows man and being to become co-constitutive (1997: 71-5) - the arguments have now definitively shifted and being is to preside over man. In his nuanced analysis of this argument, for instance, Michel Haar (1993: 57-63, 111-16) speaks of the 'false symmetry' between man and being in Heidegger's work: man is depicted through such notions as 'passivity' and 'radical receptivity' and its key anthropological attributes become those of obedience, submission, destiny and response to the demands of being. If we then try to offer a definition of being in Heidegger, the first thing to say is that already in Being and Time he had opened with the proposition that being wholly defies a positive definition: not only does 'the question of Being lacks an answer ... the question itself is obscure and without direction' (1997: 24). You do not actively look for being but let being come to you. In Letter, being is now credited with an ability to 'address' man: being 'disposes' and 'determines' man to action; being is able to will, love, need, desire; being alone is capable of freedom. The question is whether the modalities 
through which being will make itself available, visible, to man (Haar 1993: 111-37). Heidegger's being comes close to Hegel's absolute spirit, Nietzsche's Übermensch, or even ideas of providence or divinity that are defined through a negative anthropology: that which man is not. But what differentiates his argument from those of Hegel or Nietzsche is the fact that being is defined not only elusively as 'mystery', 'simplicity' or 'enigma' but also as 'withdrawal', 'concealment', 'abandonment', 'absence', 'hiding', 'errancy' and even 'distress': man is a 'sign', a 'pointer' a 'bridge' to being $(2004: 9,60) .{ }^{29}$ The negative anthropology that thus ensues is explicitly devised to understand man as lacking in genuine creative powers, reflexivity, interiority, subjectivity or autonomy, which allows for the focus on the 'thrownness' of historicity, tradition and authority. This subordination of man to being places the former in a position to receive but never to create authentic meaning. If the aim was to achieve an idea of man that does not fall back to metaphysical subjectivism, this shallow anthropology clearly succeeds because now humans are completely devoid of any possibility of agency. Haar (1993: 174-87) concludes that Heidegger moves inconsistently between a wholly historicist understanding of man that depends on language and culture as the 'house of being' and an account of the relationships between man and being that is placed at a pure ontological level as it becomes wholly devoid of any such socio-historical markers: in this second case, being always prevails and subordinates man. ${ }^{30}$

As he elaborates on the fundamental tenets of humanism in the history of Western philosophy, Heidegger criticises the traditional conception of the animal rationale because it still conceives our humanity in terms of what we share with beasts: 'Animal means beast. Man is the beast endowed with reason' (2004: 61). ${ }^{31}$ Heidegger then distinguishes between this animal rationale and an idea of the human that he himself

${ }^{29}$ Derrida (1982: 131) also uses an idea of mystery that is ultimately beyond philosophy and belongs to poetry: 'Being remains mysterious ... Being ... is nothing, is not a being, cannot be said, cannot say itself, except in the ontic metaphor'.

${ }^{30}$ Haar (1993: 113) summarises his criticism of Heidegger thus: 'there is a radical disproportion between, on the one side, the poverty and basic receptivity of man and, on the other side, the richness and inexhaustible, effusive capacity of being'. In what is otherwise a fantastic book, Haar belongs fully in the second wave of Heidegger interpretations as he sticks to the idea of a complete separation between politics and philosophy. He discusses, for instance, Heidegger's elitist definition of Volk and the irrationalism of his notions of 'resoluteness' and 'action', 'death' and 'authenticity', and even 'sacrifice' (1993: 47-50, 91, 122-3, 140-1). Haar then soberly observes that there $i$ a general trend in all cases, and that the value of man systematically recedes vis-à-vis the demands of being. He will not however be drawn to comment on the normative implications that may follow from this.

31 On the role of animals in Heidegger's thinking, see Calarco (2008: 15-53). 
recovers from the Roman idea of humanitas. A first, positive, definition of humanism is then rearticulated through Heidegger's key notion of care:

Where else does "care" tend but in the direction of bringing man back to his essence? What else does that in turn betoken but that man (homo) become human (humanus)? Thus humanitas really does remain the concern of such thinking. For this is humanism: meditating and caring, that man be human and not inhumane, "inhuman," that is, outside his essence. But in what does the humanity of man consist? It lies in his essence. (1993a: 223-4, underlining mine)

Let us first concentrate on the lower form of humanity, homo, which Heidegger defines as that man that is defined through its animalitas. The fact that humans share an organic constitution with other living creatures blocks our ability to specify the uniqueness of humanity; this is too base a ground to establish what is essential in our humanity. A form of anthropocentrism that reproduces the traditional dualisms of the metaphysical tradition - the mind and the organism, the body and the soul - Heidegger thought that philosophical anthropology encapsulated everything that is wrong with current attempts at understanding the human. In Heidegger's view, the problem lies in the dualisms themselves rather than in the side that we choose. We cannot overcome metaphysics as long as we retain this way of thinking:

The fact that physiology and physiological chemistry can scientifically investigate man as an organism is no proof that in this "organic" thing, that is, in the body scientifically explained, the essence of man consists ... Just as little as the essence of man consists in being an animal organism can this insufficient definition of man's essence be overcome or offset by outfitting man with an immortal soul, the power of reason, or the character of a person. In each instance essence is passed over, and passed over on the basis of the same metaphysical projection. (1993a: 228-9)

The apparent goal of Heidegger's humanism is to rescue humans from themselves and their ideas that they are no more than animals; only thus can the essence of humanitas be brought back to its essence. But Heidegger's idea of nature deserves closer scrutiny as it connects to his critique of defining the human through our organic constitution. If we look at what the secondary literature tells us, Heidegger's idea of nature is defined in three, apparently contradictory, ways. First, the argument has been made that, because the possibilities of historical reconciliation have become fully closed to Heidegger within the realm of human action, this is now being implicitly transferred over to a general idea of being. I will show below that Heidegger's work does resort to a logic of reconciliation, but the question that remains is whether this coheres, even if in spite of itself, 
on a pantheistic idea of nature. ${ }^{32}$ Second, Heidegger's rejection of naturalism has been presented as evidence of the incompatibility between his philosophy and the 'blood and soil' racism of the Nazis (Pöggeler 1991: 203, Safranski 1998: 236). The question is more complicated, however, because the argument has also been made that, far from opposing blood and soil, Heidegger endorsed this form of racist naturalism as a way of rejecting the 'liberal', 'positivist' and indeed 'British' form of biological thinking as represented by Darwin (Faye 2009: 66-74, 87-99). Third, Heidegger's critique of philosophical anthropology is thrown back at his own failure to say anything meaningful about the organic side of human life. The devaluation of the animal in animal rationale is seen as consistent with Heidegger's philosophical displacement of humanism, but it also leaves him with a wholly incomplete notion of a human being who has no body or physical relation to the world: even if it does not define the essential properties of the human, organic life remains one important dimension of human life as it actually is. The problem lies in Heidegger's own insistence in that he is interested in the concreteness of life, and to that extent Hans Jonas surely has a point when he claims that 'Heidegger too failed to bring the statement "I am hungry" within the purview of philosophy' (Jonas 1996: 47). ${ }^{33}$

If we now return to Heidegger's idea of the human that speaks directly to the higher humanity of humanitas, we have seen that it centres on 'meditating and caring' about the essence of being. Humanitas brings man closer to being; it is a return to the ancient Greek ideal of education, paideia, which was indeed the original term that the Romans translated as humanitas (1993a: 224). In order to emphasise the fundamentally linguistic character of meditating and caring, Letter opens with a claim that has since become one of Heidegger's best-known remarks: '[1] anguage is the house of Being. In its home man dwells. Those who think and those who create with words are the guardians of this home' (Heidegger 1993a: 217, my italics). Here, Heidegger pays special homage to Hölderlin, as poets become key to the special breed of humans whose role is to liberate language and bring it closer to what is essential: 'the world's destiny is heralded in poetry, without yet becoming manifest in the history of Being' (1993a: 242).${ }^{34}$ As for the role of philosophy, it may one day get back to

32 See Cassirer (1996: 200-9), Cohen (2006: xxii-xxiv), Haar (1993: xxx-xxxi), Löwith (1995: 89-91).

33 See also Haar (1993: 77-85) and Löwith (1970: 311-17).

${ }^{34}$ Even more concisely: 'The thinker says Being. The poet names the holy' (Heidegger, cited in Löwith 1996: 37). See also Heidegger (2004: 10). References to Hölderlin were a common trope in conservative circles at the time as it allowed for a retreat from the monumental to the intimate (Mehring 2014: 34-5). Safranski (1998: 282-88) contends that Heidegger's first 
that position of grasping genuine being, but before that can be reattempted philosophy needs to bring itself back into a position where simplicity, authenticity and mystery of being can be truly grasped. As we will see in some detail in Chapter 2, for Hannah Arendt the question of thinking is fundamentally egalitarian and worldly: thinking is one of our generic human capacities to make sense of the world that surrounds us. Heidegger also contends that thinking is an attribute of human beings because it is 'something that is done by an act of the human spirit' (2004: 127). The commonalities with Arendt end there, however. First, because in Heidegger elitism rather than egalitarianism defines thinking: 'the involvement with thought is in itself a rare thing, reserved for few people' (2004: 126). Second, because he is only interested in pure thinking; that is, the kind of thinking that distinguishes genuine philosophical genius and originality because it is concerned only with thinking itself: 'A thinker is not beholden to a thinker - rather, when he is thinking, he holds on to what is to be thought, to Being' (2004: 95).

Contemporary philosophy is in no position to achieve this genuine thinking that Heidegger contends is a precondition for the essential understanding of being. Current philosophy must abandon such metaphysical distinctions as the one between is and ought because pure thinking 'is neither theoretical nor practical' (1993a: 259). It needs to step down from transcendental principles and move back to history, back to the 'simplicity' of the spoken word whereby 'the essence of thinking' regains control over the 'technical-theoretical exactness of concepts' (1993a: 219). It is through the mastery of language, and indeed of the spoken word, that philosophy will renew itself. On the one hand, this can be read as a move against Husserl's notion that philosophy was to be successful only in so far as it was to become (re-)elevated to the 'rank of a science' (1993a: 218). On the other hand, however, Karl Jaspers saw this emphasis on pure thinking as an expression of the fact that Heidegger never really overcame Husserl's even more fundamental insight that the true task of philosophy is that of finding the Archimedean point of uncontaminated thinking: the only difference is that Heidegger approached this goal through poetry and etymology rather than through a theoretical or technical command

references to Hölderlin take place in the context of his stepping down from his position as rector and getting back to teaching in 1934-5; poetry was now to prove powerful where politics had failed him. According to Pöggeler (1991: 219), moreover, Hölderlin is also a central resource in Heidegger's dreamy references to the connections between German rebirth under the Nazis and Ancient Greece. This was not a passing phase in Heidegger's thinking, however, as similar references to Hölderlin are present in the rectoral address of 1933 as well as in the Der Spiegel interview of 1966 (Heidegger 1991a: 31-2, 37-8, 1991b: 109). Even Derrida (1991b: 69) gets eventually tired of this and seems to mock Heidegger's insistence on the 'joint privilege of German and Greek ... with regards to thought'. 
of concepts (Safranski 1998: 364-9, 388). Levinas (2006: 18) is again right when he contends that '[f] or Heidegger, being is revealed out of the abstruseness and mystery of the unsaid that poets and philosophers bring to the world without ever saying all'. Heidegger makes thus another move that was to prove crucial for twentieth-century social science and philosophy: from now on 'language dominates the philosopher instead of the philosopher dominating language' (Bourdieu 1991: 101).

Heidegger has distinguished between higher and lower ideas of man and this is key to his argument that although he rejects metaphysical humanism, this does not mean that he favours any form of antihumanism. His argument is not to be read as if 'it promotes the inhumane and deprecates the dignity of man'; rather the opposite, as we have mentioned, he contends that ' $\mathrm{h}$ ] umanism is opposed because it does not set the humanitas of man high enough' (1993a: 233-4). Heidegger echoes the Nietzschean argument on the transvaluation of values so that, after humans have demoted god, nature and history as a source of value, this devaluation has now come to bite humans themselves: the same process that allows everything to be turned into an object of subjective preference accounts now also for their own devaluation. Anthropocentrism is the current source of this systematic demotion of all values because now things can have a value only because man deems that to be the case: 'by the assessment of something as a value what is valued is admitted only as an object for man's estimation' (1993a: 251, my italics). But Nietzsche is not really being followed here because, in order to transcend the language of values and the inevitable process of transvaluation, Heidegger is after a genuine restoration. He demands a new source of values that lies above and beyond the modern devaluation and this is something that only being can offer: being endows man with value. Man is subordinate and his worthiness depends on how it cares for being; man is not and can never become a source of value. Humans are too mundane and do not reach the essential spheres where being resides: at their absolute best, only the chosen few - thinkers and poets - may be allowed to become the famous 'shepherd of Being' (1993a: 234). ${ }^{35}$

Heidegger blames the near self-destruction of modern humanity on anthropocentrism and argues that the first step forward is to reject the egalitarian rationale that we saw underpins Sartre's and most traditional forms of humanism. This separation between higher and lower forms of humanity allows Heidegger to make egalitarianism the main culprit of modern normative aporias. Heidegger's critique of humanism is then

35 See Arendt (1978 II: 158-94) for an analysis of Heidegger's reading of Nietzsche. See also Chapter 2. 
construed through a dual negation: first, being is to be preferred over the human; second, within humanity itself, higher forms of humanitas are to be cared for at the expense of animale rational. This is 1946 and Heidegger knows exactly what he is doing: after having redefined humanism along these lines, he can now state that, through the radical egalitarianism of mass society, humanism is modernity's real totalitarian ideology. The former rector rediscovers the pure thinker inside him and erects himself as the ultimate judge of what makes human beings human: at best, he dismisses nearly everything that most human beings would do throughout their lives as a lower form of humanity; at worst, these become an expression of their very inhumanity. A full-blown elitism is one key normative pillar of Heidegger's humanism; his rejection of homo humanus on behalf of humanitas is justified because the former is simply unable to 'realize the proper dignity of man' (1993a: 233, my italics). ${ }^{36}$

In fact, Heidegger's argument does not simply depend on elitism being openly preferred over egalitarianism. He contends that elitism is just a moderate price to pay in order to avoid the repetition of the massacres towards which metaphysical humanism will again lead: irrationalism is more sober and less authoritarian than rationality, authenticity and simplicity more genuine than emancipation or self-determination, poetry touches on the essential, while science and technology are merely able to manipulate instruments. Only poetry and contemplative philosophy remain pristine and unpolluted human activities in a world that has nearly destroyed itself through its unrestricted beliefs in technology, state bureaucracy and mass movements. As the latter are now used to characterise both the Nazis and metaphysical humanism, Heidegger is allowed to ask: who is actually to blame for the modern crisis? Those like him who care for being in its simplicity and mystery or those who have become intoxicated by wild promises of emancipation, social change and self-determination of modern values, machines and institutions? The real danger of inhumanity lies dormant beneath modern institutions and its metaphysical humanism; conversely, humanity's best hopes lie in those who care for the essence of being. Interestingly, however, this conservative critique will still depend on its own variant of a logic of reconciliation: we must trust those who can know better and let them show us the way.

${ }^{36}$ See Derrida (1991b: 46), Haar (1993: 141-2), Soper (1986: 58) for further discussion. At 24 years of age, a young Habermas commented that it is the lack of any universalistic underpinning that makes possible this dangerous elitism. Without 'egalitarianism', he contends, there is neither the 'counterweight against the notion of the natural privilege of the stronger nor the counterweight of cosmopolitanism against the motif of the German people as history's “chosen people"' (Habermas 1991a: 196). 
Heidegger's well-known critique of technology builds on this line of thought; this is a critique of the modern understanding of modern technology because technology has become an expression of the materialism and anthropocentrism of modern culture. Rather than being a mere instrument, technology is a 'form of truth' which 'is grounded in the history of metaphysics' (1993a: 243-4). A purely instrumental conception of technology loses sight of handicraft and its relationship to the world; instead, it reinforces the distorted anthropocentrism that governs modern civilisation: as it creates the illusion of human authorship and full control of consequences, technology triggers an inauthentic relationship between being, man and the world (1993b: 324-6, 335). Technology is to Heidegger a form of knowledge and, through the strong association between techné and episteme (1993b: 320), between science and knowledge, technology is to be seen also as an art form: ' [b] ecause the essence of technology is nothing technological, essential reflection upon technology and decisive conformation with it must happen in a realm that is, on the one hand, akin to the essence of technology and, on the other hand, fundamentally different from it' (1993b: 340). But this essential understanding of technology in its relation to being is precisely what 'technological man' cannot do within 'mass society' (1993a: 255). Modern technology is a travesty of what is essential about technology: 'The essence of technology lies in what from the beginning and before all else gives food for thought' (2004: 22). The inauthenticity of modern man is mirrored by the 'monstrousness' of modern technology (1993b: 321); Heidegger dislikes technology because it uproots and no longer allows for an authentic separation between natives and strangers: technology is to be rejected because it knows no Heimat (Levinas 1990a: $232-3) .{ }^{37}$

At this point, the inversion, the so-called turn, that Heidegger has effectuated is total: there is an anti-humanist rejection of most human activities that is however introduced as essentially humanist. Humanism has been redefined as that caring for being that lies outside mundane activities and the organic dimension of human life. This restoration of being is given the task of redefining and then looking after the essence of man; a task that requires the philosopher to remove all the obstacles with which modern life has cut off man's access to being. The oldest and primordial has now to provide orientation for the future:

37 Whether Heidegger consistently rejected technology as monstrous, or his views changed after the war and in order to separate his position from official Nazi ideology that trusted technology to deliver a future society, remains an open question (Faye 2009: 72, Safranski 1998: 275, 293). 
With regard to this more essential humanitas of homo humanus there arises the possibility of restoring to the word "humanism" a historical sense that is older than its oldest meaning chronologically reckoned. The restoration is not to be understood as though the world "humanism" were wholly without meaning and a mere flatus vocis [empty word]. The "humanum" in the world points to humanitas, the essence of man; the "-ism" indicates that the essence of man is meant to be taken essentially ... "Humanism" now means, in case we decide to retain the word, that the essence of man is essential for the truth of Being, specifically in such a way that what matters is not man simply as such. So we are thinking of a curious kind of "humanism". (1993a: 247-8, underlining mine)

Heidegger positions himself as the poet-thinker who alone is able to reclaim the purity of the Vita Contemplativa. Heidegger's self-presentation is that of a pure thinker who craves only for peace and quiet - the contemplative monk that is not even understood by most of his peers. This requires him not only to reject the modern world but also to offer a highly elitist vision of what is essential and what is base in defining humanity. But, as we will see also in Chapter 2, this is a bastard version of the vita contemplativa that is not only reductionist but is also constituted at the expense of any genuine connection to the vita activa. Heidegger cannot speak about the political context within which his interventions have taken place, about his personal failures in the modern world, but then faults the world itself for the consequences of his actions. In this restorative humanism, real human beings truly do not matter.

We must not forget that this revalorisation of the life of the mind takes place after politics had failed Heidegger and indeed after he had failed the test of politics. But politics, it seems to me, is where we find the ultimate difficulty in Heidegger's relationship to modernity. Heidegger may pretend to have nothing to say about what was happening to fellow human beings during the war, but philosophy itself did not - not least through the deeply humanist legacy of several of his own disciples: Hannah Arendt, Herbert Marcuse, Hans Jonas, Emmanuel Levinas, Hans-Georg Gadamer, Karl Löwith. ${ }^{38}$ One can almost hear the grip of Heidegger's furious hand as he writes that ' $[t]$ he essence of evil does not consist in the mere baseness of human action, but rather in the malice of rage. Both of these, however, healing and the raging, can essentially occur only in Being, in so far as Being itself is what is contested' (1993a: 260, my italics). Barred from the university, guilty of ungratefulness towards old masters, disowned by his previously adoring pupils, Heidegger is now fighting against public humiliation. Here, the question is not only about

${ }^{38}$ Within the Frankfurt school of critical theory, Erich Fromm is arguably unique in his continuous recovery of humanism. I am grateful to Kieran Durkin (2014) for clarifying this for me. 
his support for a regime that committed heinous crimes but about the seductions of power, his lack of remorse or sense of responsibility and, given his own reputation, about the role of philosophy itself:

Since ancient times philosophy, unlike every other branch of learning, has been guided by the idea that its pursuit shapes not only the knowledge but also the conduct of its disciples, specifically in the service of the Good, which is after all the goal of knowledge ... Therefore, when the most profound thinker of my time fell into step with the march of Hitler's brown battalions, it was not merely a bitter personal disappointment for me but in my eyes a debacle for philosophy. Philosophy itself, not only a man, had declared bankruptcy. (Jonas 1996: 49) ${ }^{39}$

In his intoxication with historicity and language, Heidegger lost control of his own thinking. The more he pushed for the autonomy of language, the less he had to concern himself with the actual implications of his words and, of course, his deeds. This argument can and indeed has been made as an attempt to exonerate him both politically and philosophically (Gadamer 1992). Yet it may also be seen as the ultimate warning against what may happen when, under extreme circumstances, to be sure, we actively seek to give up on 'old' humanist ideas of personal autonomy and responsibility. ${ }^{40}$

\section{III}

Even if some or even most aspects of my interpretation of Heidegger are seen as one-sided, one argument that remains is the extent to which his critique of humanism has become ubiquitous: the humanism of Western metaphysics is to blame for the contemporary crises of modern society. Through mass mobilisation, a blind belief in technology, the power of state bureaucracy and nationalism, the Nazis are an extreme but ultimately coherent result of Western metaphysics. ${ }^{41}$

${ }^{39}$ In his short stint as rector 'Heidegger failed utterly, precisely as a "Führer"' (Pöggeler 1991: 215).

${ }^{40}$ Pierre Bourdieu (1991: 105) comments as follows on this issue: 'it is perhaps because he never realized what he was saying that Heidegger was able to say what he did say without really having to say it. And it is perhaps for the same reason that he refused to the very end to discuss his Nazi involvement: to do it properly would have been to admit (to himself as well as to others) that his "essentialist thought" had never consciously formulated its essence'.

${ }^{41}$ See my discussion of posthumanism in the Introduction. Peter Sloterdijk is highly critical of Heidegger's nostalgic argument for a new humanism, and even more critical of Derrida's attempt to deconstruct it, but this kind of critique of humanism is the key point on which Sloterdijk (2009: 17) agrees with Heidegger. Sloterdijk seems to be speaking on behalf of a whole generation when he explains why humanism is to blame for the modern world's major misdeeds: 'Why should humanism and its general philosophical self-presentation be seen as the solution for humanity, when the catastrophe of the 
Jacques Derrida's discussion of Heidegger touches on several issues that we have discussed already and, given Derrida's own salience in later debates, can be taken as paradigmatic: Heidegger's anti-naturalism places his thinking at odds with any form of racial thinking, his rejection of Western metaphysics is an invitation towards a truer form of philosophy, and the interconnections between poetry and philosophy are to be given greater intellectual consideration. Derrida's difficulties in dealing with Heidegger and his legacy are a good case in point for Giles Deleuze and Félix Guattari's claim that 'it is not always easy to be Heideggerian' (1995: 108). ${ }^{42}$ As he delved into Heidegger's writing, Derrida's interpretation becomes less a philosophical exercise and more an attempt at normative self-justification that, as it departs from Heidegger's conclusions, is not prepared to disown its legacy. To be clear, my claim is not that, through his debt to Heidegger, Derrida is guilty by association (Habermas 1987). But nor am I convinced that Derrida's philosophical exoneration of Heidegger's political responsibility works at any level. The claim that there is ultimately a rationalist core in Derrida's work may be too strong a conclusion for what I am going to argue below, but I will seek to demonstrate that there remains a humanist sensibility in his thinking that ultimately betrays the hermeneutical sophistication that Derrida himself deploys in his interpretation of Heidegger. Derrida's difficulties are mostly self-inflicted, as they derive from what I consider is a failed attempt to get beyond the uncomfortable political implications of Heidegger's anti-humanism.

Derrida (1991b) devoted a short book to Heidegger where he discusses Heidegger's relationship to the Nazi regime. He does so by focusing on two texts from the period between 1933 and 1935 when Heidegger was most active politically: the inaugural address he gave as rector, which was delivered in May 1933, and one lecture course of 1934-5 that was later published as Introduction to Metaphysics. Derrida's argument for that period is that the political equivocations of these two texts represent an anomaly, a genuine exception, within Heidegger's oeuvre. It is true that we now know much more about Heidegger's biography than Derrida knew back then and this fact alone creates severe problems to his interpretation. But given that Derrida's case does not rely on biographical facts but on philosophical exegesis - indeed, it fundamentally relies on the

present clearly shows that it is man himself, along with his systems of metaphysical selfimprovement and self-clarification, that is the problem?' (my italics).

${ }^{42}$ It looks as though it is never easy to be Heideggerian: a so-called 'Derrida affair' took place upon his opposition to the republication in English translation of an interview he gave on occasion of the French translation of Víctor Farías's book Heidegger and Nazism (see Derrida 1991a, Sheehan 1993 and Wolin 1993). 
merits deconstruction as a philosophical 'method', his arguments are still worth looking at in some detail. Derrida's interpretation of Heidegger is based on three main claims.

1. There is, he contends, a subtle but unmistakable change in the way in which Heidegger used the idea of spirit (Geist) and its derivatives (geistig and geistlich). Derrida argues that spirit does not figure significantly in Heidegger's work; indeed, references to it are explicitly avoided in Heidegger's early writings and, when used, they appear always within inverted commas (1991b: 3-7, 14-30, 37, 65-6, 71-2). This detached use of 'spirit' is taken to mean a critique of Hegel's metaphysics. Hegel rather than Heidegger would have been prone to the historical and political mystification of a national Geist and it is Heidegger's very criticism of Hegel that makes him immune to that kind of hypostatisation: Geist is simply the wrong term to capture the substantive historicity of Dasein. All this changes between 1933 and 1935, however, as this is the only time when Heidegger made full use of spirit and its derivatives without quotation marks; indeed, they are italicised and emphasised as expression of Heidegger's new political commitments towards the regime (1991b: 31). But then things change again after his stepping down as rector. Whereas before Heidegger had preferred the word geistig, after 1935 the word of choice is geistlich. Derrida's case is that this modification expresses that Heidegger is dissociating himself from those writings in which he supported the Nazis (1991b: 33). ${ }^{43}$

2. Derrida accepts that, during the critical $1933-5$ period, Heidegger's use of spirit did refer to a substantial unity between the individual and the collective; a sense of unity in which total commitment was to be expected and could be demanded (1991b: 39) ${ }^{44}$ Derrida opens his discussion of the rectoral address by emphasising Heidegger's personal responsibility for the text he had penned and then delivered on behalf of a German

${ }^{43}$ I am unable to settle this, but Faye's (2009) extensive discussion of Heidegger's unpublished texts of that period offers substantive evidence against this kind of exegesis. On the wider terminological transformations that characterise the use of everyday and philosophical language during the Third Reich, see Klemperer (2013) and Voegelin (1999). An 'ideology critique' of Heidegger's jargon (but also, and equally interesting, of Jasper's existentialist writings) is classically available in Adorno (2003). The more general point concerns the merits of deconstruction as a philosophical method that does not require external factors as part of textual exegesis: whether we can isolate philosophical/etymological analysis from the use of concepts in their wider sociocultural context. This is particularly relevant here because Heidegger's appeal to a pristine philosophical language is not a purely philosophical move but an expression of his rejection of emergent mass society (Adorno 2003: 22, 35-42).

44 'The leader himself and he alone is the present and future of German reality, and its law' (cited in Janicaud 1996: 28). 
university: ' $[\mathrm{t}] \mathrm{o}$ the extent that he countersigns the assignment of spirit, the author of the Address, as such, cannot exempt himself from any responsibility' (1991b: 38). But as he elaborates on the nature of this responsibility, Derrida does not seem convinced that this really holds. He claims that ' $[0]$ ne could say that he spiritualizes National Socialism. And one could reproach him for this ... But, on the other hand, by taking the risk of spiritualizing National Socialism, he might be trying to absolve or save it ... This address seems no longer to belong simply to the "ideological" camp in which one appeals to obscure forces' (1991b: 39, underlining mine).

The German university in search for self-affirmation, the title of Heidegger's speech, is now a fully politicised institution that is committed to the nation, speaks on behalf of the state and answers only to the Führer himself (Faye 2009: 39-58). As we will see below, a major difficulty for Derrida is that in his own previous work about Heidegger he had already argued that philosophy is only viable in the context of freedom and democracy - and yet these are the very ideas against which Heidegger's rectoral address was reacting. Derrida further contends that, when spirit is used in this highly ideological context, this was meant to oppose the racialist blood and soil ideology of the Nazis. We have raised doubts as to whether this is unequivocally the case, but Derrida still criticises Heidegger because, by siding with spirit and against nature, Heidegger is now 'reinscribing spirit in an oppositional determination, by once again making it a unilaterality of subjectivity' (1991b: 39). Heidegger pays a heavy philosophical price for this uncritical opposition between nature and spirit, Derrida contends, because it is now Heidegger himself who has returned to the subjective metaphysics that he had so vehemently criticised in Being and Time. Derrida draws an explicit comparison between these two, very different, errors: the political one that led to Heidegger's support for National Socialism and the philosophical one that led Heidegger to the same kind of metaphysical subjectivism that in his view underpins our very discourses on 'democracy or "human rights", (1991b: 40). A point that we have made several times before, humanism is not only seen as impotent against totalitarianism, it actually is to blame for it. This is how Derrida takes the analogy further:

Even if all forms of complicity are not equivalent, they are irreducible. The question of knowing which is the least grave of these forms of complicity is always there - its urgency and its seriousness could not be over-stressed - but it will never dissolve the irreducibility of this fact ... In the Rectorship Address, this task is not just a risk run. If its programme seems diabolical, it is because, without there being anything fortuitous in this, it capitalizes on the worst, that is on both evils at once: the 
sanctioning of Nazism, and the gesture that is still metaphysical ... this equivocation has to do with the fact that Geist is always haunted by its Geist ... Metaphysics always returns. (1991b: 40, underlining mine)

Derrida's point remains ambiguous at best: what does it actually mean to contend that the sin of committing to the metaphysics of subjectivity and the political endorsement of the Nazis are 'irreducible'? Is it adequate to speak of a diabolical programme on the grounds that it commits to 'both evils at once' (the political one towards the party, the philosophical one towards metaphysical subjectivism?). It is difficult to agree with Derrida when he finally claims that, in relation to Heidegger's politics, 'we do not yet know what Nazism is' (1991a: 268).

3. Derrida's final step in what increasingly reads like a rescue exercise is to lower the bar for what was deemed politically reasonable in the mid 1930s. The exculpatory argument now appeals to the anti-humanist temptations that were experienced by philosophers of all credos. To be sure, the political hypocrisy from Right and Left in the use of apparently humanist values in the context of the Cold War is central to any explanation of the mainstream anti-humanism in the social sciences and humanities since the 1960s (Said 2004: 12-13, 31-56). Derrida argues that, yes, it is true that Heidegger got this very wrong, but his political equivocations are no different, they are in fact very similar, to those of so many other European thinkers at the time. The critique of bourgeois modernity that was offered by the Nazis belonged to a more general trend among intellectuals of all persuasions; or, at least, it applies to those whose boldness prepared them to enter 'into regions haunted by what is diabolical in relation to a philosophy that is self-assured in its left-liberal, democratic humanism' (1991a: 266). Derrida thus quotes at length from Husserl's The Crisis of European Science in order to show that Husserl made a similar use of the idea of spirit in that essay. He also analyses Paul Valéry's writings from 1919 in order to make an analogous claim (1991b: 120-4). The general point Derrida makes is well known, but also troublesome:

On the basis of an example taken from a discourse which in general is not suspected of the worst [i.e. Husserl], it is useful to recall that the reference to spirit, to the freedom of spirit, and to spirit as European spirit could and still can ally itself with the politics one would want to oppose. And this reference to spirit, and to Europe, is more an external or accidental ornament for Husserl's thought than it is to Heidegger's. (1991b: 121).

The argument has now shifted because here Heidegger has no special case to answer for his politics; either we all have to do so in equal measure - we are all guilty or, more plausibly, we could all have been 
guilty - or there is no use at all for the idea of responsibility in that context. There is nothing of philosophical relevance in our obsession with passing judgement on Heidegger's politics; this is just another case of victor's justice. Heidegger had consciously decided not to apologise for his deeds and Derrida has decided that half an apology will suffice. ${ }^{45}$

Let me now go back to the first text in which Derrida engaged directly with the question of humanism in Heidegger and beyond; a short piece that was composed in April 1968. A first thing to note is that Derrida devotes a long introduction to the political issues of the day (1982: 114). He explicitly mentions American involvement in Vietnam and his reservations that, by travelling to New York to attend the academic conference at which this paper was to be read, he was in no way endorsing US imperialist policies. Derrida also makes reference to the recent assassination of Martin Luther King and the entering of police forces into universities in Paris at the request of university authorities; these were all the explicit 'historical and political horizon' of his piece on humanism (1982: 114). But Derrida is not merely commenting on these very different political issues; he mentions them in order to draw two philosophical conclusions that have a direct bearing on our discussion. The first of these he terms 'the universality of philosophical discourse' (1982: 112), which he defines as the fact that international philosophical conferences transcend national parochialisms and must engage with the general questions that make philosophy a worthy intellectual pursuit. Indeed, the question of the human is central in this context: 'the interest in the universality of the anthropos is doubtless a sign of this effort' (1982: 113). The second implication refers to the interrelationships between philosophy and democratic politics, and his argument here is that only democratic dialogue can give form to an 'international philosophical colloquium': in so far as philosophers take part in these encounters, they only do so in their professional capacity - they speak on behalf of their genuine love for truth (1982: 114). Derrida put it quite strongly: 'the philosophers present here do not assume the official policies of their countries' (1982: 113). Freedom, understood as personal autonomy and responsibility, is the tie that binds philosophy and

\footnotetext{
45 This interpretation of Husserl (1970) is however disingenuous even in relation to that particular lecture: Husserl is surely to blame for his unreconstructed Eurocentrism, but the fundamentally rationalist sensibility he embraced and defended there has nothing to do with Derrida's claims in his defence of Heidegger. A certain rejoinder to Jaspers's argument on German guilt seems to be running through Derrida's partial exoneration (though Jaspers is not explicitly mentioned). The key to Jaspers's argument was that there is no such thing as collective guilt - collective actors are never to be treated as undifferentiated wholes. What matters is the personal admission of moral, political and indeed 'metaphysical' responsibility - and it is here where Heidegger fails. See Jaspers (2000: 19-27, 55-63).
} 
democratic discourse and, therefore, 'democracy must be the form of the political organization of society' (1982: 113).

These are intensely political opening remarks for a text that offers an elegant, original, but ultimately conventionally philosophical account of the same controversy on humanism that we have been revisiting so far. Indeed, it is difficult not to interpret Derrida's political overture as intrinsically connected to the political motifs that we have been discussing up to now: the apparently apolitical tone of Heidegger's Letter vis-à-vis the highly political context in which the text was composed. On the one hand, Derrida accepts the conventional self-comprehension of philosophy as an activity of unconstrained, critical thinking: '[p]hilosophy embodies the spirit of democracy insofar as it the institutionalization of radical questioning' (Heller 1991c: 493). On the other hand, it is as though Derrida is preempting the objections that may be raised against invoking Heidegger as the leitmotif for a paper on 'man' that starts with democracy and dialogue and defends a strong idea of personal autonomy. ${ }^{46}$ The philosopher that he undoubtedly was, Heidegger did not and indeed could not speak but from his love of truth: as a thinker, he could never have spoken on behalf of the nation. If the universality of the concern for the anthropos is an expression of a genuine philosophical mind, and if democracy must always be the political form of philosophy, then the democratic credentials of 'Heideggerthe-philosopher' are as good as anyone's - and through this his actual political opinions and actions are turned irrelevant. And because in this commitment to the universality of philosophical language Heidegger had renounced all other commitments but philosophy itself, we must all do likewise in order to appreciate the philosophical merits of his work: nothing but philosophical motifs are to be allowed in. In so far as Heidegger showed an interest in the universality of the anthropological question, as a philosopher he is to be welcomed in the atemporal conversation of philosophy. No further questions can, need or ought to be raised.

Derrida then reads Heidegger's Letter as an 'archaeology' whose main goal was to de-provincialise humanism: to separate it out from the tradition of Western metaphysics (1982: 128). Indeed, the very claim on the universality of the anthropological question with which Derrida opened his lecture was aimed at destabilising the ongoing debate as to whether

46 There is even the possibility that Derrida was thinking of Heidegger's failed participation in a conference to celebrate Descartes's work that was held in Paris in 1936. The reasons behind Heidegger's absence remain unclear, but late in life Heidegger still showed disappointment at not having been allowed to travel to this conference in an official capacity (Heidegger 1991b: 102). As it turned out, he was saved from the embarrassment of chairing a German delegation in which colleagues thought it fitting to attend philosophical debates wearing their brown party uniforms (Kleinberg 2003: 163, Safranski 1998: 323-5). 
Heidegger's philosophy was to be read as for or against humanism. It does not really matter whether Heidegger changed his mind on this particular issue: what is essential is the fact that Heidegger was centrally concerned with these questions because this is part of the immanent logic of philosophy itself. Derrida then moves within familiar terrain as he distinguishes two forms of humanism. On the one side, there is the kind of humanism that we associate with Sartre, metaphysics and subjectivity. Derrida sides with Heidegger's critique here and contends that this position is fundamentally misguided because of its logic of reconciliation. Sartre offers a humanism of 'unity' and, worse still, his logic of reconciliation turns Sartre's claims into a form of religious thinking in disguise: what appears to be a 'neutral' discourse favours in fact 'the metaphysical unity of man and God, the relation of man to God, the project of becoming God as the project constituting human-reality. Atheism changes nothing in this fundamental structure' (1982: 116). Sartre's humanism offers little other than a form of essentialism, and Derrida resorts to the Foucault of The Order of Things, which had just been published, to argue that 'the history of the concept of man' is still to be fully examined (1982: 116). Arguably best represented in the Universal Declaration of Human Rights, Derrida claims that this kind of humanism has become mainstream in the West after the Second World War: it is in fact 'the unperceived and uncontested common ground of Marxism and of Social-Democratic and Christian-Democratic discourse' (1982: 117).

But while this branch of humanism has remained the dominant philosophical and political discourse in France, in Germany, on the other hand, there is a different form of humanism whose trajectory Derrida traces through Hegel, Husserl and Heidegger himself. ${ }^{47}$ This variant of humanism does not have a systematic concern with 'the unity of the anthropos', which is rather seen as an open question: the grounds on which each rejected it remained 'diffuse', but they all tried to overcome this 'old metaphysical humanism' (1982: 119). A shared philosophical interest lies in their attempts towards the 'neutralization of every metaphysical or speculative thesis', so that anthropological questions can still be taken seriously because they are no longer endowed with a transcendental status (1982: 115). This is also Heidegger's challenge: to dissolve humanism's metaphysical legacy while at the same time trying to articulate a new, non-anthropocentric position that avoids antihumanism. Derrida argues that Hegel's phenomenology 'is no longer,

47 The idea that these three 'Hs' form their own humanist tradition had already been advanced by Sartre in Being and Nothingness (1957: 315-39). See also Rockmore (1995: 140). 
but it is still a science of man' (1982:120-1), whereas the jury is still out with regard to Husserl, whose philosophy openly poses the challenge that any anthropology has to face:

the critique of empirical anthropologism is only the affirmation of a transcendental humanism ... The end of man (as a factual anthropological limit) is announced to thought from the vantage of the end of man (as a determined opening or the infinity of a telos)... The name of man has always been inscribed in metaphysics between these two ends. It has meaning only in this eschato-teleological situation. (1982: 123, my italics)

I have briefly mentioned that, in his Vienna lecture of 1935, Husserl did portray Europe sitting at the top of humanity's intellectual evolution. But there is another claim that is arguably more important to us here: the unprecedented success of modern science should not blind us to the fact that science remains a fundamentally human product. Humanity is not science's primary object but remains its unique source: science is nothing but a result of human action itself. When Derrida claims that being 'remains the thinking of man' we are in fact in the presence of two different arguments (1982: 128) and this is the duality that gives title to Derrida's piece: the idea of the ends of man points to the 'double genitive' that was so important to Heidegger. ${ }^{48}$ There are those ends that humans set for themselves and whose value depend on the fact that they are pursued by human beings. And there are also those ends that speak of a movement towards human beings' own completion as human beings: man as finis refers to the human ability to endow things with a certain dignity because they are the object of human pursuit, whereas man as telos speaks about the process of immanent fulfilment of humans' own potentials. Making full use of his own methodology of writing from the margins of philosophy, Derrida elaborates on this point in a long footnote in which he explains the fundamentally Kantian horizon of this distinction (1982: 121-2, n. 15).

Derrida reconstructs Kant's predicament as follows: if Kant stays close to the idea of man as a being who can become an end in itself, then a purely empirical idea of the human is insufficient. Only self-positing reason can speak of an end in itself but, although human beings are rational, they share this property with a whole range of pure rational beings. In other words, if the idea of an end in itself was expected to endow humans with dignity, this in fact undermines the very uniqueness of the human because it refers to a notion of transcendental rather than human reason. Kant knows that humans are not pure rational beings, but he equally knows that humans are the only empirical instance of a rational being of whom we are aware. Derrida comments sympathetically on Kant's difficulty and, in fact, he

${ }^{48}$ See Heidegger (1993a: 220) and Löwith (1995: 63-4). 
holds onto it - as we said, this duality of the ends of man gives title to Derrida's piece. Derrida's reading now points in a direction that to my mind grows increasingly incompatible with Heidegger's argument in Letter:

despite the critique of anthropologism ... man is the only example, the only case of a rational being that can ever be cited at the very moment when by all rights one distinguishes the universal concept of a rational being from the concept of the human being. It is through the offices of this fact that anthropology regains all its contested authority. (1982: 122, underlining mine)

Derrida is arguing for a new lineage of humanism that recognises the ethical and even theological import of man. He accepts that the position of man is problematic at a philosophical level but, at the same time, an anthropology remains the one normative guarantee that philosophy will not turn itself against humans: '[w] hatever the breaks marked by this Hegelian-Husserlian-Heideggerian anthropology ... there is an uninterrupted metaphysical familiarity with that which, so naturally, links the we of the philosopher to the "we men," to the we in the horizon of humanity' (1982: 116). In relation to Hegel and Husserl, Derrida is critical of how they use this 'we' in which the philosopher believes he can play god; they have not fully broken free from the metaphysical logic of reconciliation. In relation to Heidegger, Derrida also speaks of a 'kind of magnetic attraction' that does not allow for the full dissociation of philosophy and anthropology (1982: 124). There is, he says, a 'hold' that remains between 'the "humanity" of man and the thinking of Being', between 'a certain humanism and the truth of Being' (1982: 123, my italics). Philosophically, humanism remains a form of metaphysics, but its disappearance leaves the door open for a non-humanism that is normatively unacceptable. Derrida uses the image of man as a gatekeeper; man becomes a methodological access point to being. The human does not disappear but its role is to be reduced to that of an entity whose goal is to allow for the enquiry into the essence of being: '[i]t is in the play of a certain proximity, proximity to oneself and proximity to Being, that we will see constituted, against metaphysical humanism and anthropologism, another insistence of man, one which relays, relieves, supplements that which it destroys' (1982: 124).

Derrida has found a good reason to keep hold of 'man': it offers a point of access to being. A certain humanism can now be retained because it no longer plays its old role as a doctrine that endowed humans with their own autonomous value; rather, humanism has become the one residual category that, above all, prevents anti-humanism. As man opens the door for human access to being, Derrida has settled for a methodological justification 
of humanism. But we have seen that this is not Heidegger's position and, as an interpretation of Heidegger, this remains problematic because it is hardly compatible with Heidegger's own elitism and irrationalism: Derrida has to overlook not only Heidegger's constant scepticism against the true philosophical value of any anthropology but also, and more importantly, against the idea that some activities (poetry and philosophy) are to remain being's excusive shepherds. Derrida does not really solve this problem; instead, we end with the worst of both worlds - on the one hand, Heidegger's insight that 'man cannot be thought as a separate entity' from being leaves the door open for all kinds of normative devaluation of the human; on the other hand, a purely instrumental idea of man as a methodological gatekeeper to something higher is no conception of man at all (Haar 1993: 73-4). Derrida will of course insist that there is in Heidegger an attempt at 'the reevaluation and revalorization of the essence of the dignity of man', but then again the only motifs that remain available for Derrida to make this claim depend on Heidegger's conservatism and antimodernism: the fact that man is being 'threatened in the extension of metaphysics and technology' (1982: 128, my italics). Derrida has run into a dead end because the more he claims that Heidegger's arguments remain a form of humanism, the more Heidegger himself is reframed within the reconciliatory logic that is central to their shared critique of metaphysics: ' $[t]$ he restoration of the essence is also the restoration of a dignity and a proximity: the co-responding dignity of Being and man, the proximity of Being and man' (1982: 130, my italics).

As Derrida reads the late Heidegger more in line with Being and Time, he disowns the more explicit anti-humanism of Letter. His is an argument for a return to the idea that man and being are co-constitutive, whereas the whole point of Heidegger's critique of metaphysics depends precisely on the rejection of that interpretation. Heidegger's mysterious being becomes in Derrida the more acceptable idea of human beings' internal transcendence: humans are beings with the ability to transcend themselves - both in thinking and in action. As they participate in the construction of this exteriority, humans do experience others and themselves as something alien and beyond their control: in society, authenticity is indeed lost. As humans are only partly authors of the world that they inhabit, philosophy and science are to be seen as human activities whose success depends on they having to abandon the anthropocentric view that humans are the only source of all value. ${ }^{49}$ Derrida's rescue exercise appears to work on the condition that Heidegger now favours the very logic of reconciliation that he had systematically criticised. Crucially, however, whereas Sartre's case

${ }^{49}$ See Norris (1987: 219-21) for further discussion. 
for reconciliation remains full of problems, he could still look positively to what humans, through freedom and autonomy, can do for others and for themselves as members of the same species. Pace Heidegger, it is Derrida who eventually clarified for us that a humanism of being is no humanism at all.

\section{Closing Remarks}

A key feature that Sartre and Heidegger share - indeed one that Sartre seems to have borrowed from Heidegger - is the notion that we ought to 'seize' the historical moment with a 'realism' that allows only for concrete alternatives. Because every situation has endless possible meanings, there is a 'radical' need for action that is to show itself in one's commitment rather than in the tentative reflection on its numerous possible paths. As a link between self and world, commitment was expected to lead to authenticity, and difficult decisions were to be reduced to two options alone: class or nation, capitalism or socialism, democracy or fascism, imperialism or anti-colonialism, them or us, the universal or the particular. Once and again both writers speak about the inevitably modern 'need to choose' and did not refrain from offering their intellectual and philosophical arguments for the cause. It has become clear, to my mind at least, that Heidegger fares politically far worse than Sartre - even as the latter is anything but a beacon of lucidity. A key lesson for us is that rather than an apparently radical need to choose, a more genuine radicalism may depend on how we reflect carefully on the normative principles we encounter in the world of politics.

As we looked at the various texts, Sartre's ultimate concern with human freedom, dignity and equality is a normative insight that we ought to retain. It is above all Sartre's egalitarianism and rationalism that radically contrasts with Heidegger's position, where elitism and irrationalism prevail. This accounts neither automatically nor necessarily for his endorsement of Nazi politics, but left him horribly vulnerable to it. This is precisely what Derrida seems to have realised as he sought to reframe Heidegger's weaknesses in two ways: first, by making a dogmatic claim on the necessary relations between politics and democratic freedom, he cleanses Heidegger's philosophy of any political responsibility; second, by re-establishing a parity between man and being, he sought to avoid, or at least contain, the antihumanist implications of Heidegger's critique of metaphysics.

Starting with Hannah Arendt, in the rest of this book we shall explore various anthropological dimensions and ideas of the human as they have transpired in both philosophy and sociology since the late 1950s. This attempt can of course be seen as a humanist enterprise: it presupposes the existence and indeed worthiness of what is about to be studied. I also 
argue that an interrogation into our fundamental anthropological features may help us reconsider the question of the normative in society. If humanism needs recovering and rearticulation in the current context, this is to be done against the backdrop of Heidegger's influence in contemporary debates. Humanism is anything but unproblematic, but its outright rejection creates even more difficulties. Let me then conclude this long chapter by presenting four main arguments that will prove of relevance in what follows.

- All claims about humanism we have looked at work through an internal differentiation between at least two kinds of humanist positions: one version is criticised and rejected, the other, in turn, is to be rescued and upheld. Interestingly, the fact that no openly anti-humanist position is favoured speaks, it seems to me, about the fundamental normative necessity of some conception of the human: they alone are the creatures that endow our intellectual work with a normative orientation. Our conceptions of the human - whether or not they are explicitly articulated - underpin our normative notions in social life. As we discussed it in the Introduction, this is precisely the main challenge that contemporary posthumanists have to face: what is the human core for which they are prepared to make a positive case so that their normative positions can be adequately accounted for.

- A first strand of humanism we have reviewed centres on inclusivity and freedom as the foundational properties of an autonomous subject. It emphasises creativity and imagination as anthropological capacities while inclusivity and egalitarianism are their main normative implications. Its key strength lies in the fact that, to the extent that it remains committed to an idea of the dignity of 'the human', we are to remain in control over the normative implications of our arguments. An idea that Kant made first apparent, the paradox this creates is that we simultaneously speak about things that are good in themselves but are only able to justify these through the subjective reference to the humans for whom this is in fact the case. On the other hand, one highly problematic aspect of this humanism lies in its logic of reconciliation, as it seems to require that we commit to the ultimate coincidence between the objective and the subjective, between the universal and the particular. The grounds on which this logic of reconciliation is sustained can be extremely varied and this explains the fact humanism can and has been promoted on all sorts of non-human grounds: divine, naturalistic, teleological and cosmological.

- A second strand of humanism defines itself in opposition to the previous one and speaks about the meaning for human life as something that 
defies or even rejects human authorship; it is rather derived from the outside. Instead of creativity, its key anthropological capacity becomes the human ability to absorb, reconfigure and ultimately accept external circumstances as they are. Meaning must then be recovered through some form of privileged engagement with art, simplicity, mystery or authenticity. A common trend that we have observed in Heidegger, Lyotard, Derrida, Sloterdijk and Deleuze and Guattari is that they make humanism responsible for the worst of modernity's deeds. This charge is based on the violence that underpins its teleology of reconciliation, and their critique appears to work because it blames the traditional normative ideals of modernity - perpetual peace, social justice, human solidarity - for modernity's chronic inability to deliver on these promises. Worse still, they blame these values for turning a blind eye on such atrocities as racism, genocide, poverty and discrimination.

- Ultimately, however, all humanist positions have to face the challenge of anthropocentrism: what are they to do with the principle of human authorship and the idea that humans are 'the measure of all things'. If too much is made of the human, then the creative prowess of the anthropos becomes also its curse; if too little is made of the human, then it can be scarified on behalf of a higher good. 
Hannah Arendt's books The Human Condition (1998) and The Life of the Mind (1978) may need to be read together in order to explore the philosophical anthropology that she never planned to write nor developed in full. Yet Arendt begins the former text, which was first published in 1958, with a claim that allows for her reflections to be read as a general anthropology. The goal there, she says, was to offer an analysis of those 'general human capacities which grew out of the human condition and are permanent, that is, which cannot be irretrievably lost so long as the human condition itself is not changed' (1998: 6). Arendt makes it immediately clear that she will not be discussing the human condition as a whole but only the so-called vita activa in its three fundamental moments: labour (the natural reproduction of life itself), work (the fabrication of material objects in the world) and action (human renewal understood as freedom). First published in 1971, The Life of the Mind supplements the first part of Arendt's philosophical anthropology by looking, inwardly, into the vita contemplativa. As we know, this book was also meant to have three sections on thinking (reason's internal dialogue that fulfils no outward purpose), willing (freedom as an act of volition) and judging (the ability to tell right from wrong, beautiful from ugly). But the project remained unfulfilled: only the first section on thinking is fully developed and the third one on judging is missing altogether. ${ }^{1}$

Arendt's idea of the human condition requires that humans position themselves as partly similar to, but also partly distinct from, animals and other living beings in the natural world. As we put both books together, they construe a philosophical anthropology because she seeks to define the general properties through which humans construe the world they inhabit. Labour, work and action on the side of active life, thinking,

\footnotetext{
${ }^{1}$ See Robert Fine $(2008,2014)$ for an account of the importance of triadic thinking throughout Arendt's oeuvre and a general assessment of Arendt's Life of the Mind. See also Heller (1991b) for an attempt to connect the three faculties of the vita activa-labour, work and action - and those of the vita contemplativa - thinking, willing and judging.
} 
willing and judging on the side of contemplative life, are all understood as equally constitutive of the ways in which humans engage with the world, other human beings and themselves. These anthropological capacities do not change historically and lay the foundations for a universalistic principle of humanity: these are properties that belong to the species as a whole in all times and places. Yet the very idea of the human condition seeks to emphasise that they are actualised, historically, in numerous different ways: it is not only that, as an idea that Arendt borrows from Heidegger, the human condition cannot but be historical. The notion of the human condition was meant to offer a way out of the essentialist implications of using ideas of human nature. The rise of modernity in particular changes the ways in which these human capacities have been actualised. As institutional contexts are transformed, the same can be said about the challenges each one of these faces and also about the tensions in their interrelationships. But our essential human features do not change, none of them disappears and there are no new properties to be included: as the human condition changes historically, its foundational anthropological features remain the same.

\section{I}

A common theme running through both books is that of the relationships between humans and the world. On the side of the vita activa, the key question is to understand how a human life is constituted through its various connections with an exterior environment. Human life takes place in a world that, while subject to human influence and transformation, is never a purely human environment. Arendt's conception of the world is articulated through the natural environment (labour), the material environment of objects (work) and the sociocultural environment of institutions and interactions (action and speech). On the side of the vita contemplativa, Arendt focuses on our human ability to momentarily withdraw from all these three worlds and thus transcend their limits: the human capacity to suspend our metabolic, material and indeed social constraints and then open ourselves to reflection, imagination and thinking. A key insight that I seek to reconstruct in this chapter is what I call Arendt's idea of self-transcendence: 'the paradoxical condition of a living being that, though itself part of the world of appearances, is in possession of a faculty, the ability to think, that permits the mind to withdraw from the world without ever being able to leave it or transcend it' (1978 I: 45 my italics). This, I contend, is her fundamental contribution to our understanding of the irreducible human powers that shape the human condition. While self-transcendence is primarily related to the 
activity of thinking, the very act of displacement that it requires can only be fully understood as we reconstruct it also in terms of its relationship to the external world. The human world that is thus created is unique because humans see and recognise each other as part of an environment that is partly independent and exterior to us but is also partly dependent on human action itself. All living species have a world of their own (1978 I: 20) and Arendt's idea of self-transcendence is the strictly human quality that humans possess as they mentally transcend their particular socio-historical coordinates. ${ }^{2}$ If this is the case, then creatures who do not have a bodily constitution, e.g. gods and angels, would have no need for self-transcendence; while creatures that depend more directly on their metabolic needs, like animals and plants, would also be unsuitable for self-transcendence. ${ }^{3}$

As animal laborans, then, humans engage with the natural world through the prism of their organic and metabolic necessity; through labour, the fruit of human toil is above all the continuation of life itself. As homo faber, humans engage instrumentally with nature and with others in order to fabricate a new, different world that is now to be populated by objects. This world of things is teleologically organised as the result of human projects - objects themselves are always designed with a purposebut given the materiality of objects and the unintended consequences of their use, the world thus constituted remains unequivocally external and indeed irreducible to humans themselves. As active beings, finally, humans live in a world that Arendt describes as plural because it is always already populated not only by other human beings but also by cultural traditions and institutional practices: this is also the life-world into which we grow 'naturally' and that, depending on the familiarity of particular experiences, we may also feel as extremely alien. Its existence is accredited not through its materiality but through the presence, actions and expectations of other human beings. Temporality is then a central feature of the vita activa: the linear and relatively short movement from birth to death that organises the life of an individual is immersed in the much larger duration

${ }^{2}$ In Imre Kertész's novel Fateless, the main character speaks about the use of one's imagination and the experience of boredom as the two main forms of self-transcendence that remain available to human beings even under the extreme conditions of concentration camps (2006: 119 and 155-6).

3 This idea of 'the world' as the totality of possible (interior and exterior) experiences is one of the aspects in which Arendt's thinking is in continuity with, for instance, those of Heidegger (2005: 1-10) and Husserl (1931). But in Husserl and Heidegger it was essential that humans are not seen as the only or indeed the highest forms of beings - let alone being as such. In their view, this implies the gravest of mistakes; namely, to reduce the general problem of philosophy to a mere anthropology. Against this, Arendt's decentring of the human condition vis-à-vis the world remains a fundamentally humanist position: her interest was above all to understand the human condition. See Chapter 1. 
that sustains material objects and social institutions. These, in turn, are also part of the even longer cyclical movements of nature itself: '[t]hat every individual life between birth and death can eventually be told as a story with beginning and end is the prepolitical and prehistorical condition of history' (1998: 184). The combination of these temporalities is essential to how we experience the human condition, Arendt contends: the constancy and stability that is required for individual human life is provided by the pre-constituted temporality of social institutions and, above all, the inert temporality of natural and material objects: '[i]f nature and the earth generally constitute the condition of human life, then the world and the things of the world constitute the condition under which this specifically human life can be at home on earth' (1998: 134; also 19, 96-8).

Arendt's depiction of the active side of the human condition is then formed by these three realms that humans experience as external in their unique way: the natural exteriority of necessity, the artificial exteriority of materiality and the intersubjective exteriority of human plurality. Exteriority, she then contends, is central to all our worldly experiences of objectivity and stability; constancy and externality are the conditions of possibility for self-transcendence. Self-transcendence, as the most internal of our human contributions to outer existence, becomes possible thanks to the all-too-real exteriority of the world we inhabit. The possibility of suspension, revision and recreation that self-transcendence requires is made possible by the ontological certainty the outside world creates: '[i]f nature and the earth generally constitute the condition of human life, then the world and the things of the world constitute the condition under which this specifically human life can be at home on earth' (1998: 134).

In addition to the five human senses with which humans interact with the world, Arendt contends that we are in possession of a sixth one that allows us to translate private sensations into public utterances: human sociality, our intersubjectivity, creates the possibility of social inclusion that we experience as a second birth. ${ }^{4}$ To the same extent that a purely private world would deprive the individual from a sense of permanence and a grasp of humanity's own plurality, we are in possession of a sense through which we experience a common world that is created by human beings themselves (1978 I: 50-8, 1998: 176). Humans have always dreamed of a way of life that is devoid of necessity and its toils, a life

${ }^{4}$ As we will see below, this idea of second birth is consistent with Arendt's idea of natality. See also Chapter 8 on the reproduction of life, where we look at the ways in which debates on reproduction and abortion are framed within the idea that the organic life of the foetus needs to be socially inscribed for it to be acknowledged as an 'authentic' human being. 
whose external restrictions are to be overcome more or less at will. To Arendt this is not really available to humans but, more importantly, it would be undesirable in so far as defining their very humanity:

[t] he human condition is such that pain and effort are not just symptoms which can be removed without changing life itself; they are rather the modes in which life itself, together with the necessity to which it is bound, makes itself felt. For mortals, the "easy life of the gods" would be a lifeless life (1998: 120)

External constraints may not be willingly embraced but they are far from disposable. This is another reason that justifies locating the ability for selftranscendence at the centre of Arendt's contribution to our understanding of the human condition: humans need, can and in certain crucial moments also must transcend the barriers and restrictions that constitute the world that surrounds them. We do this in a variety of ways - from personal empathy to theological speculation, from moral reasoning to artistic creations - but in all cases a form of self-decentring is crucially at stake: as we temporarily suspend the egocentric standpoint and try to adopt different perspectives, we are also able to bracket the restrictions that are actually in place and then imagine a different state of affairs a world that may well become different.

Defined as the intrinsically human ability to carve out a space for ourselves, self-transcendence is central to our 'interior' relation with our own self as much as it is to our relations with the world 'outside': it is to be found both in active and in contemplative life. In the case of labour, animal laborans discharges the uncertainty and toil of necessity into the stability of objects that homo faber is able to produce through work. Animal laborans is able to find self-transcendence in homo faber's ability to create useful tools and objects, and thus a world that is materially durable: this is the transcendence of urgency and necessity in the stability and planning that is afforded by tools and instrumental action. In turn, homo faber faces its own problems of 'internal transcendence'; in this case, contends Arendt, the challenge has to do with the emptiness, the 'meaninglessness', of a world that is full of material objects but has no significant others. The world of homo faber is not a fully human one because it lacks social, cultural and indeed normative standards that can effectively orient the use we give to objects: in the purely instrumental world of homo faber, nothing has an intrinsic value because everything can be turned into a means for ulterior ends (1998: 236-7). Indeed, the idea of pure instrumental action reveals itself as a contradiction in terms because when all ends can become means, then we have no ends at all as all we have are means. This tragedy of homo faber cannot be resolved internally but requires its own self-transcendence; it has to be transposed onto the realm of action because questions about the meaning of life can 
only be raised in society alongside others. Arendt argues that action and speech are different from labour and work because while individual men can live without labouring and working, they cannot do so without action and speech (1998: 176). However imperfectly, animal laborans and homo faber can be seen from the standpoint of both a single individual and a wholly homogeneous idea of humanity. Yet action and speech cannot be understood in this way because they necessarily involve human plurality. Animal laborans is a subject (to the urges of necessity), homo faber is a master (of the things it creates), but only action and speech produce the horizontal and collaborative sociality that depends on the presence of other human beings as partners and interlocutors (1998: 151). ${ }^{5}$ Equally importantly, action and speech differ from labour and work because there are no external standards that secure their fulfilment. For action and language, self-transcendence is always internal to the purely human result of human interaction (1998: 236-7). Arendt speaks of the 'threefold frustration' with our understandings of human action; namely, the fact that their outcomes are unpredictably, that chains of events may be irreversible and that authors may remain unknown (1998: 220). To act, in short, means to take initiative, to begin something that is truly new; the human capacity for 'action means that the unexpected can be expected' (1998: 178). A human is a being from whom one expects the unexpected. ${ }^{6}$

In so far as action implies renewal, natality now joins plurality as the twin pillars of Arendt's understanding of the human condition. The human freedom thus created is nothing short of unbearable:

If left to themselves, human affairs can only follow the law of mortality, which is the most certain and the only reliable law of a life spent between birth and death. It is the faculty of action that interferes with this law because it interrupts the inexorable automatic course of daily life, which in its turn, as we saw, interrupted and interfered with the cycle of the biological life process ... The miracle that saves the world, the realm of human affairs, from its normal, "natural" ruin is ultimately the fact of natality, in which the faculty of action is ontologically rooted. $(1998: 246-7)^{7}$

${ }^{5}$ In a different context, Georg Simmel spoke about the democratic structure of all sociability: 'everyone should guarantee to the other that maximum of sociable values (joy, relief, vivacity) which is consonant with the maximum of values he himself receives. As justice upon the Kantian basis is thoroughly democratic, so likewise this principle shows the democratic structure of all sociability ... Sociability creates, if one will, an ideal sociological world, for in it ... the pleasure of the individual is always contingent upon the joy of others' (Simmel 1949: 257, my italics). See Chernilo (2013a: 182-91) and also Chapter 5, below.

${ }^{6}$ In Arendt's interpretation, this indeterminacy of action leads Kant to concentrate his moral theory on motives and principles rather than on goals and consequences (1998: 235). We will come back to Arendt's interpretation of Kant.

7 This reference to natality offers a deep though largely unexplored connection between Hannah Arendt and Hans Jonas's idea of life (see Chapter 4). Safranski (1998: 383) 
The importance of plurality for Arendt's understanding of the human condition allows her to further argue that politics is an especially important domain in human life. Plurality, she argues, 'constitutes the political realm' and human plurality is expressed as both individual uniqueness and collective particularity: '[j] ust as there exists no human being as such, but only men and women who in their absolute distinctness are the same, that is, human, so this shared human sameness is the equality that in turn manifests itself only in the absolute distinction of one equal from another' (2005: 61). This existential connection between politics and plurality also accounts for the difficult relationships between politics and philosophy. In Arendt's reading, philosophy and theology share the inadequate presupposition that the human condition can be conceived as exempt from human plurality: '[b]ecause philosophy and theology are always concerned with man, because all their pronouncements would be correct if there were only one or two men or only identical men, they have found no valid philosophical answer to the question: What is politics?' (2005: 93). A further philosophical difficulty in understanding politics as human plurality comes from the fact that thinking, central as it is to philosophy, remains a solitary activity. When the tradition of political thought tries to come to terms with the fact that human life is indeed plural, it then faces the problem that it is made to go too far so that, ultimately, 'human nature' resides in politics. Quite the contrary, Arendt argues, ' $m a n$ is apolitical. Politics arises between men, and so quite outside of man. There is therefore no real political substance. Politics arises in what lies in between men and is established as relationships' (2005: 95). ${ }^{8}$ It is again the question of the relationships between humans and the world that prevents any definition of human nature as political nature. Politics is misunderstood if defined through ideas of power and domination because this wrongly equates the human fact of plurality - action and speech - with a particular set of conflictual social relations.

In relation to Western theology, its difficulties in grasping human plurality derive from monotheism: if god is one and only one, and man is created in the image of god, then all men must be the same. Likeness and similarity rather than uniqueness and plurality become the representation of what constitutes our common humanity: ' $[\mathrm{g}] \mathrm{od}$ created man, but men are a human, earthly product, the product of human nature' (2005: 93).

suggests, somewhat crudely but not without plausibility, that Arendt's concern with natality (and I think this applies also to Jonas's argument on the centrality of biological life) is an inversion of Heidegger's early concern with death in Being and Time.

${ }^{8}$ Rodrigo Cordero (2014a) has explored with great sophistication Arendt's concept of the 'in-between'. But below I will emphasise that her position is closer to mainstream sociology than she herself was able to realise. 
Theology may still think of the human as an individual whose existence is a result of non-human sources, but we cannot do the same if we contend that humans owe their nature to the existence and mutual recognition of others. Legal equality, which is an ancient rather than a modern invention, remains the most fundamental normative intuition because it gives human plurality concrete form and substantive purchase: ' $[t]$ his voluntary guarantee of, and concession to, a claim of legal equality recognizes the plurality of men, who can thank themselves for their plurality and the creator of man for their existence' (2005: 94). Arendt contends that the constancy of human dualities when seeking to account for the human condition - body and soul, interests and ideals, nature and culture - is in fact a result of human plurality. There is however a radical difference between human equality understood as something given and human equality as something that is co-constituted through human interaction. Arendt offers here her own version of the socalled secularisation debate that marks the rise of modernity:

Political equality, therefore, is the very opposite of our equality before death, which as the common fate of all men arises out of the human condition, or of equality before God, at least in the Christian interpretation, where we are confronted with an equality of sinfulness inherent in human nature. In these instances, no equalizer is needed because sameness prevails anyhow. $(1998: 215)^{9}$

\section{II}

A key element in Arendt's critique of modernism is found in her scepticism towards the utilitarian premises that play such a major role in modern societies. In its individualistic bent that centres on 'happiness', but also in its more consistent collectivist tradition that focuses on general 'utility', utilitarianism remains a flawed philosophical position because it unduly locates homo faber as the representative of the human condition as a whole. Homo faber goes to the market as the isolated producer who is prepared to exchange all the fruits of her work for the one commodity that is able to dissolve all forms of substantive value: money (1998: 166). Although in the market homo faber has a public and becomes a member of the public, she can never engage in a genuine realm of human plurality (1998: 160-2). Money as the standard that dissolves all standards, and the marketplace as an apolitical public, have become the twin institutional pillars of the modern world and its restrictive understanding of the social.

${ }^{9}$ This argument is central to Arendt's generation in their critique of the excessive modernism of the social sciences. With different political, philosophical and indeed theological overtones, we found it in writers such as Karl Löwith (1964), Leo Strauss (1974) and Eric Voegelin (2000). I have discussed this at length in Chernilo (2013a: 39-70). For a modernist counterargument, see, classically, Blumenberg (1983: 27-51). 
Because no return to the past is available, we cannot recreate absolute standards of judgement that are exempt from critical scrutiny. But as previous standards become obsolete, the human world still requires some standards because they alone express those things people care about in their own right:

[t]he loss of standards, which does indeed define the modern world in its facticity and cannot be reversed by any sort of return to the good old days or by some arbitrary promulgation of new standards and values, is therefore a catastrophe in the moral world only if one assumes that people are actually incapable for making original judgements. (2005: 104, my italics)

Human imagination and creativity are central for the renewal of standards that take place in modernity; they are central for the possibility of selftranscendence to be realised in concrete situations.

We can see the radicality of Arendt's insight if we now compare it to her rather unusual take on Kant's moral theory. On the one hand, Arendt accepts that Kant's insight that humans are to be treated as ends in themselves was devised as a way to constrain the role of utilitarianism in moral thinking. Kant's intentions were laudable as he wanted to restrict the utilitarian point of view 'to its proper place and prevent its use in the field of political action' (1998: 156). But Arendt then claims that by framing his moral theory in terms of means and ends, Kant had in fact adopted the way of thinking he sought to overcome; Kant's position is already contaminated by the very utilitarianism he was criticising. Not only that, Arendt goes as far as to say that: ' $[\mathrm{t}]$ he anthropocentric utilitarianism of homo faber found its greatest expression in the Kantian formula that no man must ever become a means to an end, that every human being is an end in himself' (1998: 155, underlining mine). Arendt justifies this indictment by arguing that Kant had no need to make this move because Plato had already made plain the reductionism that was involved in adopting a teleological approach to human action and morality:

if one makes man the measure of all things for use, it is man the user and instrumentalizer, and not man the speaker and doer or man the thinker, to whom the world is being related. And since it is in the nature of man the user and instrumentalizer to look upon everything as means to an end ... this must eventually mean that man becomes the measure not only of things whose existence depend upon him but of literally of everything there is. $(1998: 158)^{10}$

${ }^{10}$ Another, admittedly more conventional, way of putting this problem would be to argue that, while Kant sought to see private and public autonomy as co-constitutive, in the case of his moral thinking the latter has primacy over the former (Habermas 1996: 84). Whereas Kant made it clear that the public use of reason is essential for the actualisation, as it were, of the categorical imperative of morality, this has not prevented leading exponents of contemporary Kantianism, like Habermas and Rawls, from arguing that this is not enough to make Kant's position truly dialogical. See, for the opposite argument, Höffe (1995). We come back to this issue in Chapters 4, 5 and 6. 
This utilitarian approach is fundamentally inadequate when applied to the human realm of interactions because action and speech, as 'specifically human achievements', lie 'altogether outside the category of means and ends' (1998: 206-7). To be sure, from a sociological point of view, the claim that action is not to be related to notions of means and ends is counterintuitive at best. ${ }^{11}$ And below we will also see that thinking itself is equally distinct from instrumental rationality - therein lies, for instance, the mark that separates thinking as such from a philosophical quest for knowledge and the pragmatism of the modern scientific attitude. But the plausibility of the argument depends on the success of homo faber in the fabrication of the (modern) world: the more the world becomes full of useful things, the more it also becomes apparent that its meaning lies elsewhere: '[n] ot even Kant could solve the perplexity or enlighten the blindness of homo faber with respect to the problem of meaning without turning to the paradoxical "end in itself", (1998: 156). ${ }^{12}$

But before we can fully assess Arendt's interpretation of Kant, we still need to consider her wider debt to him. Thus, in her Lectures on Kant's Political Philosophy, Arendt is interested in Kant's famous dictum on the impossibility of rational metaphysics. According to Kant, metaphysics can never be rational because the most fundamental questions that humans ask themselves cannot be answered definitively and rationally; rather, they are bound to remain subject to metaphysical speculation. The so-called 'scandal of reason' consists in the inability to definitively settle the following three questions: what can I know? (i.e. does god actually exist?) what ought I to do? (how am I to handle my own freedom?) and what may I hope for? (why do I exist at all if I am going to die?). At first sight, Arendt argues, it may seem strange that Kant did not ask himself directly the most obvious question of them all - what is a human being - but then she argues that to Kant this was no more than the logical consequence of putting together those three questions (1992: 20-32). ${ }^{13}$

Arendt further elaborates that there are three perspectives through which, according to Kant, we can look at 'the affairs of men' (1992: 26).

${ }^{11}$ From Weber to Schutz and Habermas himself, the claim remains that a teleological structure is central to all forms of social action (Habermas 1984a: 102-41).

${ }^{12}$ Another way of looking at the importance of the relationship between means and ends is provided by Helmuth Plessner (1970: 38): the anthropological centrality of instrumental action derives from the particular position of the human body that is also an instrument for humans themselves.

${ }^{13}$ It is this argument on the irrational nature of metaphysics, says Arendt, that led Marx and Nietzsche to pursue it to its only logical conclusion: to abandon philosophy altogether (1992: 36). 
We have, first, the potential standpoint of the human species as a whole. To the extent that the species can duly be referred to in the singular, the continuation of its existence does depend on the successful adaptation to nature that Arendt contends can be deemed as progressive. The life of a single individual is too short to encapsulate the general progress the species does experience, but to the extent that our everyday life has been increasingly, and to great portions of the world's population completely, discharged from the toils of having to provide for our physical needs, this is indeed progress in an unequivocal sense. There is, second, the individual human being who is an end in itself. We have seen that, in Arendt's interpretation, this moral being is fundamentally dependent on homo faber, so she argues that a human as a reasonable being who is able to legislate for herself through her use of reason takes her bearings from the world of objects she herself has created. Instrumental action is then the precondition rather than the opposite of moral action: instead of being able to exercise control over instrumental action, the categorical imperative of morality is subordinated to it. There are, finally, humans in plural, men and women who live in political communities and are endowed with their intersubjective 'common' sense. Rather than isolated individuals who toil or fabricators who go to the market, here we find individuals who need one another and who, through their coordination, create the common world in which they live; people for whom sociability alone is a 'true "end"' (1992: 26).

Arendt rightly observes that there is an internal difficulty inside Kant's threefold conception of the human: while the idea of man's inner dignity the end in himself - accepts no historical progression and requires the same dignity for all human beings (past, present and future), our species's adaptation to the world is on the contrary based on an idea of progress in which the future is anticipated as superior to both past and present. Teleological justifications that refer to the species as a whole are not easily reconcilable with endowing every single individual with equal dignity and moral insight: 'the very idea of progress - if it is more than a change in circumstances and an improvement of the world - contradicts Kant's notion of man's dignity. It is against human dignity to believe in progress' (1992: 77, my italics). ${ }^{14}$ Critical as it is of Kant's arguments, this formulation still does not

${ }^{14}$ Somewhat enigmatically, Arendt summarises her views as follows: ' $\left.\mathrm{t}\right]$ he world is a beautiful place and therefore a fit place for men to live in, but individual men would never choose to live again. Man as a moral being is an end in himself, but the human species is subject to progress, which, of course, is somehow in opposition to man as a moral and rational creature, an end in himself' (1992: 31, my italics). This formulation seems to reflect the remnants of an existentialist sensibility in her work. 
explain why Arendt claims that Kant's moral theory is the greatest expression of anthropocentric utilitarianism. Given Kant's threefold idea of the human being that Arendt brings to the open, it is difficult to contend that Kant offered a reductionist account of the moral side of human beings. A more consistent argument, it seems to me, is that Kant consciously adopted the terms of utilitarianism in order to redefine them; he worked through them as a way of placing internal limitations on utilitarian positions. Ideas of means and ends are to be used with regard to human beings because they bring the potentially endless chain of means and ends to a possible normative close: slavery, standing armies, self-imposed ignorance and seeking to buy someone's assent are all affronts to human dignity on the grounds that they undermine an individual's moral integrity as an end in itself. It is Kant's modernism, his early yet insightful understanding of the relevance of instrumental rationality, that pushes him in the direction of wholly redrawing the boundaries of, and thus limiting, that can actually be thought with utilitarian concepts in the field of morality.

A more positive side to Arendt's reading of Kant becomes apparent when she discusses the idea that humans can transcend their own position in the world because they can observe it from different standpoints. There is, according to Kant, a specific form of human imagination that consists in 'comparing our judgment with the possible rather than actual judgments of others' (cited in Arendt 1992: 43, my italics). This imagination is central to the possibility of thinking, whose 'aim is to strengthen the original absent-mindedness of thought' (1978 I: 155), but it is also crucial for the activity of judgement (1978 I: 76, 92). The key here lies in Kant's idea of impartiality, says Arendt, which is not a principle of action but a viewpoint from which to 'reflect upon human affairs ... impartiality is obtained by taking the viewpoints of others into account; impartiality is not the result of some higher standpoint that would then actually settle the dispute by being altogether above the melée' (1992: 44 and 42). A universal sense of moral sympathy is a core attribute of critical thinking itself and Arendt comments on Kant's terminology by giving it a name this anthropological skill: the 'disinterested delight' or 'enlarged mentality' that depends on public communicability. Once again, speech and action are seen as the cornerstone of human plurality (1992: 43-5, 68-73).

Kant thought that, as humans, we belong always and necessarily in at least two overlapping communities: there is, first, our local community, from which we take our more direct understanding of the world, and there is also a second, broader cosmopolitan community. This is the 'world community' to which we belong 'by the sheer fact of being human ... When one judges and when one acts in political matters, one is supposed to take one's bearings from the idea, not the actuality, of being a world citizen 
and, therefore, also a Weltbetrachter, a world spectator' (1992: 75-6, underlining mine). Arendt makes here a strong connection between the possibility of impartiality and a theory of the spectator: human plurality is 'the law of the earth' because all human interventions presuppose a spectator (1978 I: 19). ${ }^{15}$ An actor can never be fully impartial because his deeds are always ultimately dependent on how he appears to others (1992: 55). The distinction between a local and a cosmopolitan sense of belonging does not neatly overlap with the one between political actor and impartial spectator, however. With regards to cosmopolitan belonging, impartiality is what constitutes us as political actors. The cosmopolitan community thus constituted is of course an idea but this does not make it any less real than the actual communities people live in: "[a]n "enlarged mentality" is the condition sine qua non of right judgment ... Private conditions condition us; imagination and reflection enable us to liberate ourselves from them and to attain that relative impartiality that is the specific virtue of judgment' (1992: 73).

This argument is full of consequences for the social sciences, as it speaks about an idea of empathy that is based on our human rather than our sociocultural commonalities. Thus seen, empathy requires that we creatively imagine what are the conditions others may be going through so that we can envisage their possible rather than their actual judgements. The fact that we can exercise this competence of comparing actual and possible judgements depends on our human ability to recognise each other as human beings rather than on whether we have experienced similar situations. Basing empathy on the particularity of common experiences alone, that is, without making use of this enlarged mentality, runs the risk of merely reproducing prejudice, self-righteousness or mere just self-interest. ${ }^{16}$ Here it is worth quoting Arendt's argument at length:

Men, though they are totally conditioned existentially - limited by the time span between birth and death, subject to labor in order to live, motivated to work in order to make themselves at home in the world, and roused to action in order to find their place in the society of their fellow-men - can mentally transcend all these

${ }^{15}$ Kant's idea of impartial observation is built on Adam Smith's (2009: 133-6, 227-46) earlier argument on the impartial spectator. More generally, there is the wider 'Copernican' question of man's position in the universe: to observe the starry heavens as a way of reflecting on our human position in the cosmos (Blumenberg 1987:3-27,60). In Blumenberg's reconstruction, the human proclivity to theorising belongs to our interest in contemplatio caeli (contemplation of the heavens): 'The condition for our ability to observe heaven is the earth under our feet' (Blumenberg 2015: 49). See also Hawkins (2015: 143-8) and note 17, below.

16 Contemporary arguments on 'intersectionality' wholly miss this point and, on the contrary, are based on the impossibility of this withdrawal, which they can only see as deceptive, naive, arrogant or self-serving (Walby et al. 2012, Yuval-Davis 2006). 
conditions, but only mentally, never in reality ... They can judge affirmatively or negatively the realities they are born into and by which they are also conditioned; they can will the impossible, for instance, eternal life; and they can think, that is, speculate meaningfully, about the unknown and the unknowable. And although this can never directly change reality - indeed in our world there is no clearer or more radical opposition than that between thinking and doing - the principles by which we act and the criteria by which we judge and conduct our lives depend ultimately on the life of the mind. (1978 I: 70-1, my italics)

Seen as the mental precondition for self-transcendence, thinking is not something that takes place freely or effortlessly. Alienation and selftranscendence are intimately related in Arendt's argument because they offer one general form in which humans set out the relationships between the interior life of the mind and the exterior worlds of nature, instruments and sociality. As with Hegel and Marx, for Arendt alienation is not something exceptional but it is rather normal occurrence in human existence. Alienation is one fundamental dimension that transpires from the intrinsic difficulties that come with this dual process of inward and outward self-decentring: alienation is another name for the gap between the general possibility of self-transcendence and its always contingent and challenging realisation. Indeed, Arendt's opening image in The Human Condition - space travel - is for her the quintessential expression of the twofold alienation of modern society: as the escape from the world into the self becomes increasingly tiresome, humans now attempt a new, apparently more radical but arguably even more futile, escape from the earth into the universe: '[w]orld alienation, and not self-alienation as Marx thought, has been the hallmark of the modern age' (1998: 254). ${ }^{17}$

\section{III}

We have said that, In Life of the Mind, Arendt's argument on thinking, willing and judging is construed in a similar way to how, in The Human Condition, she had introduced labour, work and action. In the case of our mental faculties, it is the temporal dimension that organises Arendt's triadic structure: thinking belongs to the present, judging belongs to the past and willing to the future (1978 I: 191). Thinking plays a major role in the argument on the vita contemplativa because it is the skill that actually

${ }^{17}$ In The Human Condition, Arendt discusses space travel as part of the permanent quest for an 'Archimedean point'. See also (1998: 1-6, 262-4, 284; 1978 I: 54, 62-5). Daniel Sage (2014) has uncovered the wide range of nationalistic, civilisational and religious connotations that space travel achieved in the US at the time, and one may wonder whether Arendt also fell in love with some of these epochal overtones, or indeed whether she used these tropes consciously in order to appeal to her American audience. 
makes willing and judging possible. Thinking alone allows for the withdrawal that is necessary for the activation of the life of the mind as a whole; thinking implies a temporary yet essential withdrawal from the world, it requires the suspension of our relationship with the world and comes to an end as soon as 'the real world asserts itself again' (1978 I: 75). ${ }^{18}$ The thinking ego is neither an empirical self nor the soul in so far as they are concerned with our feelings and bodily experiences. The thinking ego has the ability to offer a critique of that which appears as given and thus involves a 'radical' break from what becomes available to the senses; the thinking ego is therefore 'ageless, sexless, without qualities, and without a life story' (1978 I: 43). What makes the thinking ego radical is the fact that it takes objects as they are given in the world and then attributes to them a new, general, meaning through this mental 'experiment of the self with itself' (1978 I: 74). Pure thinking is constituted in this fashion: 'it is this duality of myself with myself that makes thinking a true activity, in which I am both the one who asks and the one who answers' (1978 I: 185). ${ }^{19}$ The thinking ego, then, is unconditioned, invisible, reflexive and self-contained. But given the fact of human plurality, Arendt argues that the thinking ego, while it lives in solitude, it is never lonely; it is soundless though not silent, it needs words but has not listeners (1978 I: 32, 47, $71-5,98-9)$. The thinking ego is singular but is never only one: the thinking ego is 'the two-in-one of soundless dialogue ... while engaged in the dialogue of solitude, in which I am strictly by myself, I am not altogether separated from that plurality which is the world of men and which we call, in its most general sense, humanity' (2005: 22).

This intrinsic unworldliness of thinking makes it hardly surprising that it has traditionally appeared as the opposite of the active life. The same unworldliness, moreover, prevents us from turning thinking into the key or essential marker of the shared humanity of human beings. Through its rejection of appearances, the thinking ego possesses an intrinsic reflexive ability that is fundamentally 'self-destructive' with regard to 'its own results ... thinking itself can never be solidly established as one and even the highest property of the human species' (1978 I: 88). Yet at the same time, as a purely contemplative life is not wholly human, Arendt equally contends that a life fully devoid of thinking also 'fails to develop its own essence - it is not merely meaningless; it is not fully alive. Unthinking men are like sleepwalkers' (1978 I: 191). Thinking as the possibility of self-transcendence, connects rather than separates the vita activa and the

${ }^{18}$ See also (1978 I: 32-5, 43, 72-8, 87-92, 197-9, 205-6).

${ }^{19}$ See also (1978 I: 179-93). To that extent, Arendt's notion of thinking comes close to the idea of internal conversation that we will explore in Chapter 7. 
vita contemplativa: 'whenever I transcend the limits of my own life span and begin to reflect on this past, judging it, and this future, forming projects of the will, thinking ceases to be a politically marginal activity' (1978 I: 192). Because thinking is another particular expression of human plurality, it is also deeply connected to politics.

There is still one further quality of the thinking ego that Arendt addresses in a more allegorical language. The thinking ego, she says, is 'the fellow who awaits you if and when you come home'; it is only possible as I become my own friend (1978 I: 191). There are some puzzling aspects in Arendt's argument here. The notion of being one's own friend may be seen as taxing psychologically but does not necessarily contradict the spirit of Arendt's argument: I must be at ease with myself so that I can think as I talk freely to myself. But the reference to 'home' as necessarily a good place, the one you look forward to going back to, seems at odds with the critical and reflexive distance that constitutes the thinking ego - and indeed to her own idea of cosmopolitan belonging. Home may well be, for a number of different reasons, the last place to which you want to return and, as you nonetheless do so because it is home after all, it may well be the case that you do not find friends there.

Thinking as the two-in-one of human life, thinking as withdrawal from the world, thinking as homey friendship; to these now Arendt adds thinking as the curiosity that is necessary for science and philosophy to emerge: 'it is in the nature of the human surveying capacity that it can function only if man disentangles himself from all involvement in and concern with the close at hand and withdraws himself to a distance from everything near him' (1998: 251, my italics). But science and philosophy do differ in their intellectual attitudes; not least in relation to the type of questions they pose (and the answers that would then be deemed acceptable):

In asking ultimate, unanswerable questions, man establishes himself as a question-asking being. This is the reason that science, which asks answerable questions, owes its origins to philosophy, an origin that remains its ever-present source of throughout the generations. Were man to lose the faculty of asking ultimate questions, he would by the same token lose his faculty of asking answerable questions. $(2005: 34)^{20}$

While thinking as a pure anthropological capacity is not to be equated with philosophy as a whole, it is still the case that more 'permanent' metaphysical or existential - questions bring thinking closer together

${ }^{20}$ In different formulations of this argument, however, Arendt hesitates: while she most consistently contends that 'old' questions remain but answers change historically (1978 I: $10)$, in her more political essays she does doubt whether traditional 'metaphysical' questions remain at all relevant in modern life (2006: 8). 
to philosophy than to science. In relation to the former, she however rejects any version of dualism in which true 'being' opposes the realm of appearances (1978 I: 42, 46). At the same time, Arendt criticises any anthropocentric interpretation of the world as if it were a human creation that exists only for the fulfilment of human purposes: nobody can really make himself or produce his own existence (1978 I: 215).

This is not the place to attempt a thorough account of Arendt's relationship with Heidegger, which has of course been a source of extended commentary and gossip. ${ }^{21}$ But given that they both directed systematic attention to the question of thinking, some remarks are relevant to our discussion. Arendt takes from Heidegger the opening statement that, in the philosophical tradition, thinking is defined as the opposite of action: thinking implies withdrawal and there is a close connection between thinking and poetry (1978 I: $71-5,108)$. But the commonalities stop there as Arendt's argument is construed as a rather explicit counterpoint to Heidegger's: if for Arendt thinking refers to the internal dialogue of a thinking ego that is directed to objects in the world, for Heidegger pure thinking is the elite activity of the chosen few. For Arendt, as we have seen, thinking is the general anthropological capacity of stop and think that allows humans not only to regain some control over their lives but to creatively envisage something that is new. For Heidegger, on the contrary, it is defined in terms of the fundamental realisation that thinking is exclusively to do with thinking itself. Thinking is the professional craft of the philosopher; the slow, painful and authoritative listening to the great minds of the past in a process that leads to understanding the one idea that a genuine thinker may be able to develop over the course of a lifetime (Heidegger 2004: 15, 30, 50). The worldliness of Arendt's conception of thinking is the exact opposite of Heidegger's ethereal conception of it. The following quotation describes what Heidegger considers is the wrong approach to thinking. But what he says there can be used as a positive definition of Arendt's own approach to thinking

as a theme with which one might deal as with any other. Thus thinking becomes the object of an investigation. The investigation considers a process that occurs in man. Man takes a special part in the process, in that he performs the thinking. Yet this fact, that man is naturally the performer of thinking, need not further concern the investigation of thinking. The fact goes without saying. Being irrelevant, it may be left out of our reflection on thinking. Indeed, it must be left out. For the laws of thought are after all valid independently of the man who performs the individual acts of thinking. (Heidegger 2004: 115, my italics)

${ }^{21}$ See Brunkhorst (2014), Jonas (2008: 59-72, 176-94), Tchir (2011) and Young-Bruehl (2004: 50-69). 
The idea that thinking can be explored without humans is of course wholly alien to Arendt, for whom it is precisely the human quality of thinking that makes thinking worthy of attention. And indeed the last sentence in the quotation above does not refer to the laws of logic that may be said to rule abstract thinking, but to the fact that being calls for thinking (Heidegger 2004: 120-5). Arendt's humanism, and the development of an increasingly systematic anthropology, are antithetical to Heidegger's project.

In fact, in The Life of the Mind Arendt mentions Heidegger several times but she does not focus on Heidegger's lecture course What Is Called Thinking? Her most significant discussion of Heidegger in that book takes place in the context of her discussion of willing. Arendt pays special attention there to Heidegger's studies of Nietzsche, which took place immediately after his failed period as rector. Heidegger delivered his Nietzsche lecture courses between 1936 and 1940 and Arendt contends that while Heidegger first accepted the Nietzschean vision of the will to power, he then turned against it and came up with a negative rendition of it as the 'Will-not-to-will' (1978 II: 172-94). It is this reinterpretation of Nietzsche, says Arendt, that is at the heart of Heidegger's famous 'turn' or 'reversal'. In her interpretation, this is an argument that refers less to the move from an anthropology of Dasein to a metaphysics of Being in general (as we discussed in Chapter 1) and more to the philosopher's realisation that the will to action, the will to impose one's will on the world, is to be resisted by an even more decisive 'Will-not-to-will'. Although the reversal only became apparent with the publication of Heidegger's Letter on Humanism in 1947, Arendt contends that, biographically, it is to be traced to this period in the late 1930s: " $\mathrm{t}$ ] his re-interpretation of the "reversal," rather than the reversal itself, determines the entire development of Heidegger's late philosophy' (1978 II: 175). As Heidegger rejects the modern subjectivism of the will, the only notion of the will that remains acceptable for him is the 'Will-not-to-will': even then, however, will is secondary to contemplative pure thinking (1978 II: 185).

Arendt reads Heidegger's rendition of this 'Will-not-to-will' as the definitive expression of his old master's political repentance: after having committed to self-affirmation of the Volk, the only acceptable form of will that remained open to him was the one that rejected willing altogether: '[i]n Heidegger's understanding, the will to rule and to dominate is a kind of original sin, of which he found himself guilty when he tried to come to terms with his brief past in the Nazi movement' (1978 II: 173). Not altogether different from Derrida's interpretation of Heidegger, Arendt here seems primarily interested in reintegrating Heidegger into the philosophical canon by showing that his commitment to Nazism was shortlived, inconsequential and, above all, that through the means of 
philosophy Heidegger did show the kind of remorse that he never offered in public. But Arendt has no need to offer the kind of hermeneutical sophistication that we encountered in Derrida because she was also to make a biographical connection to the thinker himself. Her act of rehabilitation has the authoritative, yet also somewhat fallacious, tone of those who knew events and characters first-hand.

\section{IV}

If we go back to the issue of Arendt's depiction of the modern world, we may remember that we started this chapter with the claim that, while the anthropological capabilities that Arendt is speaking about are a general property of the human species as a whole, their instantiation is fundamentally dependent on socio-historical circumstances. Arendt claims that the rise of modern social life implies a threefold reversal of how the human condition discloses itself to us. First, there is the experience of an inversion in the hierarchical position between active and contemplative life: while in premodern times the latter was consistently regarded as superior to the former - not least because the distinction itself was coined and sustained by philosophers themselves - in modern times the opposite has become the case: deeds rather than speech, technology rather thinking, have taken centre stage. This may be seen as Marx's greatest contribution to our understanding of modern social life. To Arendt, Marx breaks with the conventional philosophical predicament that thinking ranks higher than action by locating 'interest' - collective class interest - as the essence of our humanity: ' $[\mathrm{w}]$ hat $i$ decisive is the further linking of interest not so much to the laboring class as to labor itself as the preeminent human activity' (2005: 79). Arendt's argument is not only that the vita activa has become more appealing in modern times, but that the vita contemplativa itself is no longer able to engage with the transformations and challenges of modern times: '[o]nly when the vita activa had lost its point of reference in the vita contemplativa could it become active life in the full sense of the word' (1998: 320).

The second inversion speaks directly to the question of freedom. In classical times, politics was seen as the realm of freedom whereas the household was that of necessity and personal domination. But in modernity the opposite is the case: politics is treated as the realm of power and domination while the private sphere - from the family to the market - is closer to ideas of freedom, autonomy, authenticity and self-realisation. Indeed, Arendt's well-known argument on 'the rise of the social' centres precisely on the idea that the interrelationships between the public and the private are anything but pristine in modern times (1998: 31-3). 
The third and final inversion has to do with the fact that these two transformations make it more difficult to appreciate the changes that have taken place within the vita activa itself (1978 I: 6-7). More than the instrumentality of homo faber, she contends, what has truly triumphed in modern society is animal laborans and the reproduction of life itself. Animal laborans inhabits a world that knows only of necessity and where there is no genuine public realm - indeed, not even a market as a partly public domain. Above all, this is a world that loses sight of its own human face: ' $[\mathrm{m}]$ an cannot be free if he does not know that he is subject to necessity, because his freedom is always won in his never wholly successful attempts to liberate himself from necessity' (1998: 121). Human plurality itself is being transformed because its core has been transposed from politics to 'the economy'. But when interest rather than freedom is seen as constitutive of human plurality, then the normative dimension of social life has itself been reduced to a resource that can be mobilised and traded more or less at will.

In modern society, direct connection to the reproduction of life is no longer visible and everything seems to hinge on consumption, but Marx himself had perceived that liberation from production, rather than emancipating mankind from necessity, tied humans back to the most basic life processes. The new realm that is now commonly referred to as 'society' can then become a legitimate domain of social scientific study because its constitution includes all relevant features of capitalist modernity. A preference for equivalence, predictability, regularity and functionality are all attributes of modern society that have then become central to the constitution of behaviouralism, functionalism and statistics as mainstream scientific approaches to the 'social' (1998: 42-3). Society then becomes the way in which 'the fact of mutual dependence for the sake of life and nothing else assumes public significance and where the activities connected with sheer survival are permitted to appear in public' (1998: 46). The rise of modern sociological knowledge took shape under the sign of this paradox: while it is meaningful knowledge because it starts from the recognition of uncertainty as a fundamental trait of the human condition - plurality and natality make incessant renewal an ontological fact - the social sciences direct all their efforts to narrow down this uncertainty on the basis of 'scientific' generalisations that can count as predictions with a policy intent. Arendt's critique of social scientific thinking contends that regularities and predictions are not to be the ultimate goal of social science. Differently put, while social scientific thinking believes it has succeeded in capturing the key mode of existence of homo faber, this is in fact inadequate because in her view animal laborans has in fact more important in modernity. But there is another criticism of mainstream social science 
that is possibly more central - and it is not cognitive or epistemological but is rather normative in orientation:

The trouble with modern theories of behaviourism is not that they are wrong but that they could become true, that they actually are the best possible conceptualization of certain obvious trends in modern society. It is quite conceivable that the modern age which began with such unprecedented and promising outburst of human activitymay end in the deadliest, most sterile passivity history has ever known. (1998: 322 , my italics $)^{22}$

Arendt criticises the self-fulfilling aspect of social scientific thinking: the more influential social scientific explanations actually become, the more they transform social relations after their own image. The objectivity of their propositions is then an expression of the newly found social relations that they themselves have helped create.

I have already mentioned that the normative motifs of her critique were indeed shared by several other intellectual émigrés who in the 1930s and 1940s had also been subjected to the degrading experiences of persecution, statelessness and exile. To them, social scientific confidence, optimism, and claims to have discovered the ultimate sources of stability in social life, were bound to look lame, voluntaristic, when not outright delusional and dangerous. Arguably the strongest formulation of Arendt's objections to mainstream social science can be found in her reply to Eric Voegelin's review of Origins of Totalitarianism. There, she explains that the goals of her historical study on the rise and main features of modern totalitarian regimes could not be accomplished in a purely descriptive manner:

To describe the concentration camps sine ira et studio is not to be "objective," but to condone them; and such condoning cannot be changed by condemnation which the author may feel duty bound to add but which remains unrelated to the description itself. When I used the image of hell, I did not mean this allegorically but literally ... I think that a description of the camps as Hell on earth is more "objective," that is, more adequate to their essence than statements of a purely sociological or psychological nature. (Arendt 1953: 79) (23 $^{2}$

${ }^{22}$ Peter Baehr $(2002,2010)$ has studied at length Arendt's relationship to the social sciences of her time. See also our discussion of homo sociologicus in the Introduction (pp. 7-10).

23 Their explicit differences notwithstanding, Voegelin's (1999) own study of the discursive structures of Nazi Germany supports this view that normative descriptions are the only adequate way of understanding the regime and its deeds. That Arendt's arguments here belong in the same breath as others in this generation of intellectuals becomes clear as we see, for instance, how closely this formulation resembles Leo Strauss's position: 'A social science that cannot speak of tyranny with the same confidence with which medicine speaks, for example, of cancer, cannot understand social phenomena as they are. It is therefore not scientific. Present-day social science finds itself in this condition'. But, as the 
A strong though still relatively unarticulated idea of normative description is what transpires from Arendt's argument here. Her normative condemnation of the camps becomes a more adequate description of them because, in the camps, the very idea of humanity is under siege. Indeed, Arendt herself makes this point in Origins: the camps were a human experiment at transforming human nature itself (1976: 437-9). Of course, not all 'scientific' propositions will engage or touch directly on questions about the humanity of human beings. But the general argument that I defend in this book, and its idea of philosophical sociology, speak precisely about the need to explicitly articulate a universalistic principle of humanity. In turn, this means that the normative and descriptive tasks of the social sciences are intimately intertwined. The attempt at the destruction of human plurality constitutes the normative core of what the idea of crimes against humanity sought to protect (Jaspers 2001). In addition to the violation of the physical, social and emotional integrity of individual human beings, it is the destruction of plurality - of the multiplicity of ways of living that expresses human variety - that gives normative credence to the idea of crimes against humanity. $^{24}$

But beyond her critique of modern social science, there is also a sense in which Arendt seems to have lost track of what the social sciences can actually contribute to in our understanding of the modern world. In her understandable irritation with sociology's narrow-minded positivism and dogmatic functionalism, for instance, Arendt misses the point that her own idea of politics is introduced in a way that is perfectly complementary to the standard sociological theorem that society is an emergent realm that must be granted an autonomous ontological status vis-à-vis the individual: the space whose structure she seeks to understand comes very close indeed to some of sociology's best conceptions of society. ${ }^{25}$ Her own ideas of plurality and worldliness, her notion that action is not possible in isolation but is always part of a wider web of acts and words (1998: 188) is again very close to, say, Simmelean notions of sociation. Indeed, what she offers here is what we may call an 'action-based' (as opposed to a systemic) theorem on the emergence of society: social life is different from human action but,

quotation continues, it also becomes apparent that Strauss's project of seeking to restore social scientific knowledge to a status quo ante is alien to Arendt's spirit: '[i]f it is true that present-day social science is the inevitable result of modern social science and of modern philosophy, one is forced to think of the restoration of classical social science' (Strauss 2004: 49, my italics). See also Baehr (2010).

${ }^{24}$ See Benhabib (2004) for further discussion and Benhabib (1996) for a wider assessment of Arendt's views about modernity.

${ }^{25}$ While he was equally critical of sociology's positivistic and functionalist tendencies, Adorno (2000) offered a more nuanced vision of the philosophical strengths of a sociological understanding of society. 
because society ultimately refers back to what happens to human beings, then it cannot be fully separated from a consideration of their humanity. The eloquence of her formulation makes it worth quoting it at some length:

The space between men, which is the world, cannot, of course, exist without them, and a world without human beings, as over against a universe without human beings or nature without human beings, would be a contradiction in terms. But this does not mean that the world and the catastrophes that occur in it should be regarded as a purely human occurrence, much less that they should be reduced to something that happens to man or to the nature of man. For the world and the things of this world, in the midst of which human affairs take place, are not the expression of human nature, that is, the imprint of human nature turned outward, but, on the contrary, are the result of the fact that human beings produce what they themselves are not - that is, things - and that even the so-called psychological or intellectual realms become permanent realities in which people can live and move only to the extent that these realms are present as things, as a world of things. (2005: 106-7)

As I have tried to reconstruct it in this chapter, Arendt's argument about the human condition centres on four key propositions: renewal, plurality, withdrawal and materiality. Renewal, first, is defined as the intrinsically human capacity to start something a new, as expressed most fundamentally in the human natality. Plurality, second, refers to the fact that we always and necessarily live with others and in a world of practices and traditions that comes to us as pre-constituted. Withdrawal, third, is the human ability not only to reflect but also to temporarily take leave of external constraints in order to gaze at the world from a cosmopolitan, enlarged mentality. The materiality of the world, finally, emphasises that only material objects, as human artifice, guarantee the stability that makes human life possible. Exterior to us and subject to instrumental manipulation, the world remains partly opaque to human beings.

Arendt explicitly distinguishes between the historicity of the human condition and the anthropological universality of the vita activa and the vita contemplativa. She rejects the idea that the sum of all human activities is human nature and contends that there are no rational grounds to presuppose that humans have a timeless essence that can be described as 'nature' (1998: 10-11). Yet the idea of human nature remains available to humans themselves as we reflect on our own constitution as human beings. This movement is precisely what I have sought to reconstruct here through her idea of self-transcendence. 
For several decades, received sociological wisdom has been that Talcott Parsons's structural functionalism offers a vision of the human being that is straightforwardly passive and role conforming. This assessment, which usually centres on a critical reading of Parsons's (1970 [1951]) The Social System, is based on the claim that consensually established cultural values frame the pool of acceptable responses for individuals within any given social setting. Through processes of internalisation, institutionalisation and socialisation, members of society would all from a young age learn what is expected of them; in turn, society's mechanisms for punishments and rewards would be institutionalised through an equally consensual and consistent pattern. ${ }^{1}$

One problem of this line of critique is that, at best, it is only a partial representation of Parsons's position; not least as he effectively disowned the central tenets of this intermediate theoretical framework soon after publication (1953). Yet the fact that his definitive theoretical model of the four functions - the so-called AGIL - still has no apparent place for the active powers of agency does not help the case of Parsons's defence. From a strictly sociological perspective, Parsons's concept of the modern individual is little more than a residual category within his explicit project of conceptualising social relations as an emergent and autonomous domain, and modern societies as an evolutionary accomplishment of the human species as a whole (1971). While modern individualism became a salient ideological and cultural force in modernity as early as the seventeenth century (Macpherson 1964), for most of Parsons's career ideas of the individual and the human are little more than a black box: they were expected to provide all the necessary elements, though inconsistently put

${ }^{1}$ Canonically, this critique is available in Alvin Gouldner (1973), C. W. Mills (1961) and Ralf Dahrendorf's discussion of homo sociologicus (see Introduction). The 'definitive' formulation of this critique belongs to Dennis Wrong (1977: 31-54) and his idea of the 'oversocialised concept of man'. It is worthy of note, however, that Wrong himself grew increasingly dissatisfied with the exaggerated way in which this criticism was being misused. See also Menzies (1977) and Owens (2010). 
together, of an implicit anthropology. Parsons did have the tendency to exaggerate normative integration in society and he did pay particular attention to the internalisation of norms and the ability to conform to institutional behaviour. We do know, moreover, that this is connected to his early critique of neoclassical economics and the homo oeconomicus: Parsons pushed for the institutionalisation of sociology as a social science on the grounds that it made visible the normative structures that made possible instrumental and strategic action (Camic 1991). Considerations about the autonomy of the individual were systematically undervalued as part of the effort of delimiting a strictly social world that was to become sociology's specific cognitive domain.

But for the project of a philosophical sociology, the idea of an 'oversocialised concept of man' remains insufficient as an account of Parsons's idea of the human. It shall be my contention that, while it $i$ possibly to interpret Parsons's conception of the human as role-adaptive behaviour, this is the case only in relation to his narrow disciplinary interest in sociology - not least in relation to the centrality of the idea of society as the paradigmatic social system. ${ }^{2}$ But my starting point in this book has been that, in order to fully grasp underlying conceptions of the human, no single disciplinary position is enough. Parsons did make it clear, moreover, that while his immediate interest was in sociology, the ultimate goal of his theoretical project was the development of a general theory for the human sciences that was to focus on the idea of action (1977). Sociology remained central throughout his career, of course: first, because AGIL itself emerged out of a sociological perspective and was thus formulated always as a social understanding of science; second, because sociology was the particular science that concentrates on the symbolic and interpretative character of human action. But we will see that Parsons fully realised that sociology was insufficient for the study of human action as a whole - not least because human action could not be reduced to its symbolic aspects. Indeed, there is a permanent tension in his writing between engaging and developing theoretical arguments for a unified science of sociology and the broader, even more ambitious project of a general theory of human action. It is then hardly a coincidence that one of his last published papers is explicitly devoted to how can AGIL contribute to the development of 'the paradigm of the human condition' (Parsons 1978). As we explore this general argument on the human condition, rather than the derivative conception of modern man that comes out of his sociology, a more nuanced picture emerges, one that becomes useful for the project of

2 This is, in effect, the strongest influence Parsons exercised on the most salient representative of the next generation of sociological functionalism - Niklas Luhmann. See, above all, Luhmann (1977). On Parsons's threefold definition of society as social system, modern society and nation-state, see Chernilo (2007a: 85-93). 
a philosophical sociology. Parsons explicitly makes the link that I have argued is central for my project: the intimate connection between conceptions of social relations and anthropological assumptions about our shared human attributes. Theorising the human condition, he says, illuminates the fundamental 'assumptions of social ordering at the human level' (Parsons 1978: 371).

\section{I}

Organised around the mature formulation of his AGIL model, and first published at the time when his influence was already at its peak, Parsons's (1964a) piece 'Evolutionary universals in society' offers an excellent introduction to the most general propositions of Parsons's thinking: the relationships between the nature and culture, the challenges of reflecting on long-term evolutionary trends, and the role and location of normative ideas in the social world. Here, Parsons systematically applies AGIL to the organic, human and sociocultural domains and, crucially for us, he opens with an explicit criticism of previous approaches in anthropology and sociology because they are 'conspicuously anthropocentric' (1964a: 339). Parsons's rejection of an anthropocentric perspective here is based on two grounds. First, the epistemic status of AGIL was always justified as the development of an abstract theoretical model that did not rely on the 'internal' or 'subjective' perspectives of participants. Based as it was on Alfred N. Whitehead's (1997) analytical realism, the systemic character of AGIL is underpinned by an understanding of natural reality that is itself emergent, autonomous and self-organising (Parsons 1961). Whitehead's view, which Parsons followed, was that the natural and physical worlds are not organised for the purposes of human life, so from a scientific point of view an anthropocentric perspective is fundamentally flawed. Second, and this refers directly to the substantive issues Parsons raises in this article, he sought to emphasise the ways in which the humanity of human beings is, in its organic dimension, 'in direct continuity with the sub-human' (1964a: 339). An understanding of those aspects that are universally present across human societies requires us to pay simultaneous attention to what unites and what separates humans from other living species. Parsons is expressing here one of his deepest convictions that, unsurprisingly perhaps, has not been picked up in the sociological literature: the need to engage with the biological side of human life - if not with biology as such. ${ }^{3}$ But in Parsons's account this

${ }^{3}$ For instance, in the piece on the human condition, Parsons formulates this argument thus: "less harm has been done by social scientists "biologizing" action phenomena directly than 
Table 3.1 The human condition, the action system and the modern social system

\begin{tabular}{llll}
\hline \hline & Human condition & Action system & Modern social system \\
\hline A- Adaptation & $\begin{array}{c}\text { Physico-chemical } \\
\text { system }\end{array}$ & Behavioural system & Economy \\
G-Goal attainment & $\begin{array}{c}\text { Human organic } \\
\text { system }\end{array}$ & Personality & Politics \\
I - Integration & $\begin{array}{l}\text { Action system } \\
\text { L- Latency }\end{array}$ & Society & Societal community \\
\hline \hline
\end{tabular}

\begin{abstract}
${ }^{1}$ Here there is a change in terminology in relation to earlier formulations. Parsons had originally included the idea of 'organism' in this cell (Parsons and Platt 1973: 436), but later on he commented that, given Freud's argument on the organic dimension of the human personality, it made more sense to locate the organic, under $G$, as part of the system of the human condition (1978: 353).
\end{abstract}

engagement with general biology does not represent a surrender of the autonomy of social and cultural factors vis-à-vis their organic foundations. Rather the opposite, and in open contradiction to any form of biological reductionism, a strong idea of the biological is offered precisely as a way of certifying society and culture's own autonomy. The idea of unified science that underpins Parsons work is organised around a multilayered conception of reality that is the exact opposite of any form of reductionism. ${ }^{4}$ A full discussion of Parsons's AGIL would make this chapter even longer and there is abundant literature that has done this extremely well. ${ }^{5}$ Their main terms are summarised in Table 3.1.

Evolutionary universals are then defined as a 'complex of structures or associated processes' whose developments favour 'the long-run adaptive capacity of living systems' (1964a: 340). Throughout this paper, Parsons offers a relatively long and not altogether consistent list of such evolutionary universals at various levels. Most saliently, he mentions: the

by their failure to attempt the requisite theoretical understanding of the organic level' (1978: 354). Steve Fuller (2011: 7-68) has explored this constitutive neglect of biology by early sociology and his contention is that, because they construe limits to what can be socially construed, biology and theology are the two major counterpoints of the early sociological imagination.

${ }^{4}$ Parsons systematically rejects a narrow (i.e. biologicist) interpretations of Freud (Parsons 1978: 82-8) and, as we will discuss extensively below, he is equally against a purely normativist or idealist interpretation of Kant, and against a sociological reductionism that equates the social to the symbolic.

${ }^{5}$ Parsons $(1961,1966,1971)$ did this himself several times, and one of the clearest expositions can be found in Toby (1977). Among the secondary literature, see Alexander (1987), Mouzelis (1995, 1999), Münch (1987). 
Table 3.2 Evolutionary universals at the organic, human, sociocultural levels

\begin{tabular}{llll}
\hline \hline Function & $\begin{array}{l}\text { Organic evolutionary } \\
\text { universals }\end{array}$ & $\begin{array}{l}\text { Human evolutionary } \\
\text { universals }\end{array}$ & $\begin{array}{l}\text { Sociocultural evolu- } \\
\text { tionary universals (as } \\
\text { expressed in modernity) }\end{array}$ \\
\hline $\begin{array}{l}\text { A-Adaptation } \\
\begin{array}{c}\text { G-Goal } \\
\text { attainment }\end{array}\end{array}$ & Vision & $\begin{array}{l}\text { Technology } \\
\text { Kinship and } \\
\text { stratification } \\
\text { I- Integration }\end{array}$ & $\begin{array}{l}\text { Market (capitalism) } \\
\text { Bureaucracy (political } \\
\text { democracy) } \\
\text { Law (equality before } \\
\text { the law) }\end{array}$ \\
Latency & Brain & Religion & $\begin{array}{l}\text { Legitimacy traditions } \\
\text { (cultural } \\
\text { universalism) }\end{array}$ \\
\hline \hline
\end{tabular}

human brain, vision and hand, technology, language, kinship, religion and cultural legitimisation, money and markets, class stratification, universalistic norms and democratic associations. ${ }^{6}$ Table 3.2 organises Parsons's findings of three types of evolutionary universals - organic, human and sociocultural - for each of the four general subsystems of the AGIL model.

One of Parsons's key arguments here is that the evolutionary universals around which human life has developed are related to both the physical adaptation of humans to the natural world and the development of those 'higher' features that make cultural, social and indeed moral life of humans unique vis-à-vis other living species. To that extent, Parsons's argument here belongs in the tradition of philosophical anthropology that sees human nature (a term, admittedly, that is alien to Parsons's vocabulary) as intrinsically dual: it is exclusively human at a sociocultural level but, organically, it equally belongs to the realm of nature. He takes this duality seriously and uses it as the basis on which to build analogies between the cultural and the organic domains. For instance, he defines the human brain, which in his view is less uniquely human than the human hand, as 'the organic foundation of culture' (1964a: 340), and he then moves on to contend that 'gene' and 'symbol' are the foundational aspects of organic and sociocultural

${ }^{6}$ Parsons closes the piece with the proviso that the general approach (i.e. the idea of evolutionary universals) is more important at this stage of his thinking than the actual list (1964a: 356-7). For a methodological reflection on this way of constructing general theoretical arguments, which Parsons used in various other contexts, see also Baum (1977) and Münch (1987: 220n). 
evolution, respectively (1964a: 341$).{ }^{7}$ The major observable discontinuity between organic and cultural adaptation is of course the fact that the latter lends itself to diffusion in a way that the former does not. Because humans are living beings, adaptation is as central to them as it is for all living creatures; at the same time, our specificity as humans means that questions of adaptation can no longer be treated exclusively at an organic level; they need also to include sociocultural developments. A theme that will also reappear below, this duality explains what makes the relationships between the functions (A), of organic adaptation, and (I), of sociocultural integration, of critical theoretical importance for the conceptualisation of the human condition.

As he turns his attention to the normative foundations of collective life, Parsons argues that all forms of cultural legitimisation emerge out of the human need to create some sense of belonging. The general proposition he offers is that the delimitation of a 'we' is key for the definition of the normative: 'we-ness' is always to be 'asserted in a normative context' (1964a: 345). With this reference to a normative context, Parsons emphasises that all cultural traditions, to the extent that they are oriented to questions of legitimisation, are also and simultaneously trading in transcendental arguments. Religion is not treated as an evolutionary universal because of its institutional importance - nor, indeed, because a particular conception of the divinity is to be preferred - but on the grounds that the organisation of human life requires some transcendental vanishing point. Constructions of the 'we' may then be oriented by a universalistic outlook that focuses on commonalities and inclusivity, or else they may take a more particularistic route and concentrate on uniqueness and specificity. Parsons fully realises the different implications that ensue from taking either option: '[i]f the others are clearly recognized to be others ... they are regarded as not "really human"'; in these cases, they are 'strange in the sense that their relation to "us" is not comprehensible' (1964a: 345). But to the extent that most forms of sociocultural legitimisation do include some universalistic orientation (e.g. equality before the law), Parsons also contends that restrictions of this human status are bound to remain temporary. If we then include the self-legislating dimension that is built into all forms of democratic legitimisation, Parsons's claim on the universalistic underpinnings of normative institutions is now offered as an empirical trend as much as a normative one. Sociocultural differences between peoples are the grounds on which a sense of 'we-ness'

\footnotetext{
${ }^{7}$ In this sense, Parsons's use of organic analogies is more theoretically consequential than Durkheim's (1992: 30, 50-1) much looser use of such organic metaphors as the state being 'the social brain'.
} 
is of course construed, but they are however underpinned by our similar status as human beings. Modern times become a unique occurrence in human history because the emancipatory potential of its inclusive universalistic orientation has the potential to be realised institutionally: '[i]f a single keynote of the main trend of the development of modern civilization could be selected, I think it would be the trend toward cultural universalism ... universability is one of the central conditions of freedom' (1978: 345, my italics). ${ }^{8}$

If we now turn our attention to his piece on the human condition, the essay is significant because it is the one piece in which he fully articulated the anthropological presuppositions of his thinking. Crucially, Parsons will turn his back on the anti-anthropocentric perspective that had been a fundamental trademark of his work. An anthropocentric standpoint was now needed because studying the human condition can only be done from the perspective of humans themselves. Parsons then commences this article with the admission he is working on the 'hunch' that AGIL, which had already proved useful in various partial fields, may also prove of relevance in relation 'to the other features of the world with which humans necessarily have occasion to deal with' (1978: 326). If we then include the eassy 'Death in the Western world' that immediately precedes the piece on the human condition, this is far more than a mere hunch; there are well over one hundred pages whose arguments are formulated with the help of Parsons's highly technical terms: they were indeed the culmination of three decades of theoretical writing. For AGIL to become the major theoretical framework Parsons wanted it to be, so the argument goes, it now also had to prove 'successful' in what was arguably the most vexing of intellectual domains: the conceptualisation of 'the human'. Parsons organises the discussion of the human condition following AGIL, and for each of the four systems he selects canonical writers in modern science and philosophy that in his view have made the greatest contribution to our understanding of these domains:

${ }^{8}$ The salience of 'cultural universalism' as the most important normative innovation of modern times is a long-standing insight of Parsons's work. This arguably transpires most clearly in his political writings; for instance, in his essays on Nazism and Nazi Germany in the late 1930s and 1940s, he systematically contends that its major threat was that the Nasiz sought to destroy all forms of normative universalism (Gerhardt 1993). Later on, more or less at the same time as this publication on evolutionary universals, Parsons wrote a piece on the blatant incongruities of the second-class status of 'the American Negro' in the context of the universalistic underpinnings of US political and legal institutions (1967b: 422-65). And he also argued for the need that US involvement in international affairs be based on an international rule of law (1967c, 1969a). I have discussed these aspects of Parsons's political sociology in Chernilo (2007a: 77-85 and 2009). See also Buxton (1985) and Gerhardt (2002). 
- The function of adaptation (A) has the 'physico-chemical system' as its locus and its main task is to conceptualise the human organism's exchanges with the natural world. This subsystem responds to the requirement of getting all the resources that are needed for the material continuation of life (1978: 362). Here, Parsons uses Lawrence Henderson's work in biology, whom alongside Norbert Wiener he describes as 'amongst the most intellectually respectable "metascientists" of the present century' (1978: 387). Parsons also draws on Albert Einstein in relation to our new understandings of how the laws of causality work in the physical world (1978: 357-60).

- The function of goal attainment (G) centres on the 'organic system'. Parsons adopts Ernst Mayr's notion of 'teleonomy', which he defines as the goal orientation that is part of all living systems (one, however, that does not need to include the rationalistic bias that is present in utilitarian positions). ${ }^{9}$ Parsons draws also from Norbert Wiener's cybernetic insights about organisms being 'information processing system(s)' (1978: 376) and from Sigmund Freud's notions of ego, id, libido and cathexis as definitive contributions to our understanding of psychological life (1978: 368-9). ${ }^{10}$

- The function of integration (I) is where the action system itself is located. This is of central importance because it becomes 'the point of view of the observer', that is, the location from which the whole attempt at studying the human condition is being made. This is the integrative experience of trying to make sense of human experiences of the various worlds into 'some kind of meaningful whole' (1978: 362). Here Parsons draws above all on Max Weber's notions on the symbolic, interpretative and indeed creative aspects of human understanding of sociality: symbolisation is always subjective and remains an exclusively human property (1978: 372, 389-90).

- The function of latency (L), finally, is located at the top of the cybernetic hierarchy in terms of information - this is the realm where ultimate questions and values are raised. He defines it in terms of the ability for

${ }^{9}$ Health is thus defined as the teleonomic capacity to 'maintain a favourable, self-regulated state that is a prerequisite of the effective performance of an indefinitely wide range of functions both within the system and in relation to its environments' (1978: 69).

${ }^{10}$ Parsons's relationship with cybernetics is ambivalent here, however. On the one hand, he makes extensive use of the idea of cybernetic hierarchies of information and energy. On the other, however, Parsons's new emphasis on the anthropocentric perspective that is needed for theorising the human condition goes against Wiener's (1954) general argument that cybernetics offers a general theory of communication, of which human communication is only a specific instance. Rather the opposite, in the case of the human condition Parsons has to argue that this is a unique property or ability of humans. See also Chapters 4 and 5 . 
'tension management' that is required in so far as such telic problems as 'suffering and evil ... arouse strong emotions in human beings' (1978: 363). Here Parsons draws on Kant, from whom he takes the idea of a non-empirical reality, the need for a transcendental enquiry into the conditions that make rational knowledge possible and, last but not least, the categorical imperative of morality as the ultimate representation of human self-transcendence (1978: 393).

An explicit 'existential' sensibility is alien to Parsons's self-conception as a scientist who is interested in developing a general conceptual framework. This is made unequivocally clear in the essay on the human condition, which was 'meant to be primarily a theoretical attempt rather than an addition to the voluminous philosophical and in the humanistic sense critical literature' (1978: 352) ${ }^{11}$ Rather than a substantive definition of human nature, Parsons favours a multilayered approach to the human condition that is built on the four subsystems of AGIL. The operation with symbolic meanings (Integration) and a sense of the transcendental (Latency) are its first two constitutive elements: 'only man among known living systems has telic problems ... they are problems of an order that do not arise unless the capacity to learn and use symbols and their meanings already exists' (1978: 364, my italics). But humans are not purely ideal or cultural beings, so the human condition has also a physical environment, the so-called organic (Goal attainment) and physicochemical (Adaptation) systems: ' $\mathrm{t}$ ] o say that the individual of reference "is human" is thus not only to characterize a unique organism but also to place that organism in a larger biological context' (Parsons 1978: 383, my italics). Parsons's definition of the human organism then sees it, simultaneously, as a living and a sociocultural entity. Because it operates with symbols (though not only with symbols, as we will see below), the personality is thus emergent vis-à-vis the adaptive side of the behavioural organism. A human being is both and simultaneously organic and sociocultural and the locus of our human experiences is located in three separate environments: the physical world of matter, the organic world of life, and the non-empirical world of ideas (1978: 327, 331-2, 338-40). A human being 'constitutes a unique symbiotic synthesis of two main components: a living organism and a living personality' (1978: 346). This multidimensional character of Parsons's principle of humanity is an insight that we ought to retain; for Parsons, the emergence of telic problems (i.e. questions about the meaning of life) is intrinsically connected to our organic constitution that is of course pre-social: they exist together

${ }^{11}$ This scientific sensibility explains Parsons's explicit disassociation with Arendt's previous usage of the expression 'the human condition' (1978: 326). 
as part of our general anthropological features. The human condition is then defined as the way in which

whatever universe may in some sense be knowable and which is quite specifically and self-consciously formulated and organised from the perspective of $i$ ts significance to human beings and indeed relatively contemporary ones. From this point of view, $i t$ is the system of action that constitutes the necessary reference base for such an enterprise ... The action system is, in our opinion, the most sophisticated cognitive framework within which this perspective has yet been formulated ... We therefore write and speak as human actors within that framework and attempt to relate ourselves to the rest of the human condition on the assumption that in the relevant sense this is "what we are". (Parsons 1978: 382-3, my italics)

A first thing to note in this definition is that the human condition is an inescapable human world whose primary inhabitants are human beings themselves and whose very understanding is only available to human beings. Comprehending the human condition is only a problem to and for human beings because they and they alone are concerned with the world they inhabit: "[o] ur question is, in what does this "world" consist from a human perspective?' (1978: 383). Trying to come to terms with the human condition is itself a key aspect of what makes human life specifically human, and what is specific about modern humans is that they now can attempt this through scientific means - which for Parsons was undoubtedly the most rational form of knowledge.

Let us remember at this point that, at the opening of his article on evolutionary universals, Parsons had argued that an anthropocentric perspective was effectively detrimental to scientific advancement. Indeed, such an anthropocentric perspective was problematic for the development of AGIL as a general theoretical framework because the best possible understanding of the world as it actually is does not have to coincide with what humans feel, want, need, or expect from the world. In the essay on the human condition, Parsons remains committed to AGIL as a general framework for the scientific study of any form of reality and, to that extent, from the standpoint of AGIL the conceptualisation of the human condition is merely 'a special case of the more general fourfunction paradigm' (1978: 363). This argument we have encountered before: the modern scientific imagination, of which AGIL is an expression, was nor developed in order to theorise the human condition, nor did it have as a primary preoccupation the humanity of human beings. Instead, the very possibility of developing the kind of sophisticated understanding of science that, for instance, underpins modern technology requires an anti-anthropocentric view of the world. Arguably the most intriguing aspect of Parsons's piece on the human condition is the fact that he almost obsessively repeats the idea that, for his current purpose, 
the argument must now work from an anthropocentric point of view. $\mathrm{He}$ repeatedly makes the claim that, as a human attempt to understand what makes a life human, such an attempt is only possible from an 'anthropocentric point of view' (Parsons 1978: 361). ${ }^{12}$

The fact that AGIL is now being applied to the human condition is related to two different questions. First, and this is Parsons's explicit argument, because in order to prove its scientific completeness, AGIL must prove itself against all kinds of phenomena. But the second reason only remains implicit in Parsons's argument: humans pose existential questions about who they are and what is their position in the larger cosmos, and AGIL must now also prove itself at this level. Humans are beings who reflect about themselves, the world and their own position in the world. As a scientific approach, it must help humans to make sense of their own experiences in the world: humans are beings who do philosophical anthropology. ${ }^{13}$ This dual predicament, the scientific side of AGIL and the 'existential' side of human life itself, places Parsons under the difficult position of having to disown his previous rejection of anthropocentrism. In order to conceptualise the human condition faithfully, AGIL must also be able to work from an anthropocentric point of view. The transition we have witnessed from an evolutionary argument that is anti-anthropocentric to the one currently being put forward that must remain anthropocentric is fundamentally connected to the newly discovered side of his 'philosophical' interests. Parsons elaborates on the duality of the human condition as something that cannot be conceived without specifying an anthropocentric standpoint but which, simultaneously, cannot be reduced to it. In Parsons's own words:

in what does this "world" consist from a human perspective? Entering on the consideration of this question, then, an initial point of reference must be that "I," that is, any human actor, am at the same time an actor in our analytical sense and a living organism of the species Homo sapiens. As organism, my identity is not specified by being human alone, but within that rubric I belong (anatomically) to one of two sex categories and have a fairly definite place in a structure of age and succession of generations. At higher levels of aggregation, I may be identified as belonging to an ethnic group, a territorial-residential group, and various others.

To say that the individual of reference "is human" is thus not only to characterize a unique organism but also to place that organism in a larger biological

${ }^{12}$ I counted at least nine times in which Parsons makes this point in the essay but not once does he attempt to explain why this is actively needed, or how does it relate to his previous position that anthropocentrism acts as an epistemological obstacle (1978: 361, 372, 391, 399, 405, 408, 412, 414, 415).

${ }^{13}$ Parsons carries his own 'performative contradiction' in this regard because, as we will see, he eventually has to accept that a purely scientific account of problems and questions that are primarily existential rather than scientific is unsatisfactory for human beings themselves. 
context. To say that organically "I am human" is to assert membership in a particular organic species that most notably is characterized by a highly specific genetic heritage. (1978: 383)

Parsons needs to square a difficult circle here. His various references to the organic side of human life point to the fact that adaptation is of primordial importance for any serious attempt at studying human properties. Indeed, given the multilayered nature of his argument, Parsons's idea of human adaptation surely has its emphasis on material and biological adaptation but cannot be reduced to it. The anthropocentric requirement of his argument - the fact that the paradigm must prove meaningful for humans themselves - needs to be reconciled with the anti-anthropocentric requirement of the 'objectivity' of both the natural world and of our organic constitution as members of the species Homo sapiens: the use of AGIL in the study of the human condition must meet both demands at the same time. The anthropocentric perspective Parsons is trying to develop emerges in a dual process of differentiation: on the one hand, the scientific context within which AGIL is construed does not privilege a human standpoint; on the other hand, the subjective perspective of an individual, and even the general perspective of the species as a whole, in which AGIL must now also help humans make sense of the world: '[s] ince we are engaged in constructing scientific theory, the paradigm itself must be judged in terms of its cognitive meanings as a "contribution to knowledge" put forward by one set of human beings for consideration and evaluation by others who may be interested in it' (1978: 362). In Parsons's technical language, this tension is expressed in the fact that, in the paradigm of the human condition, the function of integration works also as the point of observation for the whole model: for all versions of AGIL, the point of observation is always the function ' $I$ ' (1978: 362). But the delimitation of the anthropocentric perspective takes place primarily with regard to questions of adaptation - as said, in both its external reference point vis-à-vis the natural world and its internal differentiation vis-à-vis a plurality of possible meaning. As we mentioned above, then, the most important relationship among the four subsystems is that between integration and adaptation (I-A).

Yet a certain irony that seems to be lost on Parsons: while the scientific standpoint of AGIL may or even must detach itself from the anthropocentric perspective in order to gain the level of abstraction that we demand from scientific theories, the kind of concerns that are being raised in the piece on the human condition is bound to remain existential or normative rather than purely cognitive. Differently put, the very interest of trying to make scientific sense of the question of the human condition is something that Parsons the scientist can only partly account for: the human 
motivation for the development of science is not itself scientific. Against Parsons's own self-understanding, my claim is that what makes this proposal particularly challenging is not whether it eventually succeeds in scientifically illuminating one or another aspect of the human condition. Its relevance has to do with its anthropocentric quest for locating science in general, and the social sciences in particular, within wider normative, existential, interests. However sophisticated scientifically, the significance of asking about the human condition is not primarily scientific: it is rather to do with the meaning of life as experienced by human beings themselves.

\section{II}

The argument on our shared anthropological properties that we have reviewed so far bears little resemblance to any notion of oversocialised, role-conforming behaviour. Indeed, after having spent nearly three decades developing a strictly sociological theory of social systems, Parsons is now much more interested in the definitions of the action system and the human condition itself. The idea of system has been dramatically downplayed to the status of a methodology, while references to the social increasingly fade into the background. In fact, the argument can be made that a strictly sociological perspective is absent from his argument on the human condition: the anthropological emphasis seems to have taken over the strictly social one. To be sure, the social has not disappeared altogether and finds its location within the action system of the human condition: questions of meaning and symbolisation are indeed fundamentally social. But it is worthy it attention that, when looking at the human condition, Parsons goes from the position of the individual as a unique organism to the general reference of human species as a whole: the strictly social dimension of human life is not theorised with a similar degree of detail.

The argument can of course be made that, as sociality (i.e. the social system) has been displaced to the position of an internal environment of the system of action, this in fact demonstrates that, at the level of theory construction, society remains emergent vis-à-vis human action. But the move also has a more problematic side because the symbolic dimensions of action had already been defined as fundamentally social. Parsons runs into trouble because he cannot really explain where does action end and society begin; it looks as though that Parsons has effectively conflated the two. As he now speaks more consistently of 'action theory' and 'the system of action', reality as such needs to include explicitly the world as seen and experienced by human beings. The cybernetic modulation of his argument moves between information ( $\mathrm{L}$ - the cultural system) and 
energy (A - the physical environment). In Parsons's idea of human action, the human dimension refers precisely to the cybernetics limits of (A) and (L), while its action component refers to the organic side of the personality (G) and the symbolic aspect of the social (I).

This renewed interest in action may be interpreted as a partial return to his own earlier insights on the importance of the subjective point of view as discussed in Structure of Social Action. First published in 1937, Structure makes for an interesting comparison in relation to the later volumes on action theory $(1977,1978)$. Crucially, there are no explicit ideas of system or function in Structure, so there can be no straightforward 'return' to the subjectivist standpoint of his early work. The question now for Parsons is rather to explicitly justify why such a return is needed given that AGIL had already proved scientifically successful; he will have to find a way of going back to 'action' without undermining the abstraction and generality that has been gained thanks to a systemic point of view. We have said that this is indeed the point: the development of a scientific perspective - this is what it means that AGIL is not construed from an anthropocentric point of view - that allows for a completely new understanding of the problem of the human condition. But this, in order to be consistent, must be both scientifically meaningful and able to make sense from the 'internal' standpoint of humans themselves.

Comparing Parsons's late work with Structure is also instructive in terms of style. Although the interest in systematic theory building is present throughout his oeuvre, 80 percent of Structure's nearly 900 pages are devoted to a detailed interpretative reconstruction of works by Marshall, Pareto, Durkheim and Weber. Even as Structure can be criticised for a certain lack of hermeneutical acuity - there is something rather naive in the way in which Parsons claims to be reading these texts correctly (1937: 12-15) - the interpretative sensibility of this early work is alien to Parsons's later writings. These are of course full of canonical references but textual support for his interpretation of particular writers is almost non-existent. Parsons consistently adopted an approach to scientific knowledge and theory construction that centred on ideas of a unified conceptual framework that builds through accumulation. ${ }^{14} \mathrm{He}$ clearly sees his own work as belonging within this fantastic pantheon of Western science and philosophy that includes the names that we mentioned above - from Kant to Freud and Einstein. And he makes this proposition in two

${ }^{14}$ For all his sustained criticism of positivism as a form of reductionism, Parsons's own approach to the advancement of science finds here its own positivist bent. But because positivism argues that 'facts' alone drive scientific knowledge forward, and it therefore fundamentally undervalues the role of theoretical work, Parsons remains ultimately a critic of positivism (1978: 354). 
different capacities. As a sociologist, first, he is to sit alongside Weber in having made the idea of action central to our understanding of social life; second, and more generally, he is also to share a pride of place with Kant as the one who was able to generalise action theory and turn it into the paradigm that is able to include in an integrated way the advancements of all scientific disciplines. This we may see as Parsons's 'Comtean' view of the contribution of sociology to scientific development: the physical sciences were at the intellectual forefront during the seventeenth century, the biological sciences took up the baton in the eighteenth century, but now in the nineteenth and twentieth centuries the turn has now arrived for action sciences:

All students of human action have long been aware of the importance to human beings of the physical world, the organic world, and, though its status has been more controversial, the "transempirical" (telic) world, besides that of action itself in our technical sense. What is new in the present venture is the attempt to put their relations to action and to each other into a more systematic framework. (1978: 361, my italics $)^{15}$

Interpreting Kant is a thread that runs through several chapters of this book, so it may be worth considering in greater detail Parsons's rendition of Kant. Parsons contends that to Kant we owe our more refined insights into how to conceptualise the duality of human nature (1978: 334-5). As he was interested both in our empirical impulses and psychological motivations and in our transcendental sense of moral duty, Kant sought to offer a definitive break from both physical and metaphysical dogmatism a philosophical rejection of any kind of reductionism. Parsons's argument on the interrelations between the physical (A) and the telic (L) is explicitly built on Kant's own differentiation between the empirical and the transcendental, so for him it is wrong to read Kant as having taken sides in the debate between idealism and materialism. The two realms of reality remain symmetrical in Kant, he argues, and Parsons translates this insight into the cybernetic idea of having to conceptualise their interrelationships. As mentioned above, the physico-chemical system is superior to the nonempirical one with regard to adaptation and energy, but the opposite is the case as values and transcendental ideas possess infinitely higher information content: all components of the human condition ought to be included within this cybernetic hierarchy (1978: 326-7).

${ }^{15}$ See also (1978: 346). It is worth noting here that, with regard to religion and the difficulties of defining the 'transempirical', Parsons contends that 'with full recognition of the philosophical difficulties of defining the nature of that reality [i.e. religion] we wish to affirm our sharing the age old belief in its existence' (1978: 356). Parsons's methodological atheism is however more successful than Jonas's (Chapter 4) or Taylor's (Chapter 6). 
Parsons describes Kant's epistemological position as 'skepticism' (1978: 342) - he even speaks of 'Kant's relativism' (1978: 340) - and justifies this in terms of Kant's clear sense about the limits of what human knowledge can achieve. Kant's rejection of the possibility of a rational metaphysics is central to this characterisation: absolute knowledge is impossible for human beings because we have no access to any definitive 'conception like that of the ontological essence of nature, the idea of God, or the notion of the eternal life of the human soul', they are just not 'demonstrable by rational cognitive procedures' (1978: 347). Kant was then right in affirming the transcendental character of the categories of nature, god and the soul with which humans organise their knowledge of these three realms. This Kantian influence justifies Parsons's claim that the 'human orientation' that is central to the paradigm of the human condition cannot be 'treated as dogmatically fixed in the nature of things' (1978: 347). But this is only half of the story, because Kant serves Parsons above all to emphasise 'the continuing subjection of human life to the constraints of the transcendental aspects of the human condition' (1978: 347). What mattered to Kant, Parsons contends, is that telic or normative problems do not exist in isolation from our organic adaptation to the world. Transcendental questions are independent from but do not exist above or beyond our material and organic existence. It was above all in Critique of Fudgment, says Parsons, where Kant made the claim on the mediating role 'from the human point of view, between the necessities of the empirical world and the freedom of the world of morality' (1978: 339, my italics). Human life properly called always and necessarily takes place within this tension between the freedom of not being determined by the exterior nature of things in the world and the constraints of human beings' internal transcendence. ${ }^{16}$

In relation to the self-reflective project of humans achieving definitive knowledge about the human condition itself, we have mentioned that Kant postulated the ultimate impossibility of philosophical anthropology as rational metaphysics. This is different, however, from giving up on the possibility of rational knowledge of human affairs. Rather the opposite, Kant connected it firmly to the procedural core that underpins the categorical imperative of morality (1978: 344). But Parsons's rendition of Kant is vexed by the same difficulties that had troubled Kant himself: while their cognitive projects pushed them to use the more neutral tone of systematic formulations, the existential impulse behind the very raising of these questions

${ }^{16}$ I have elsewhere argued that this tension between the empirical and the transcendental, the particular and the universal, is central to Kant's theory of morality as apparent, for instance, in his notion of unsocial sociability. See Chernilo (2012a, 2013a : 121-31). 
ends up imposing itself as they are applied to the human condition: humans do philosophical anthropology because, in the organic adaptation to the world, they have the natural tendency to speculate on the meaning of life.

This more existential dimension of Parsons's work is not always easy to find. But in his essay on Death in the Western World, Parsons does offer some hints; for instance, as he describes human life as 'a challenging undertaking that in some respects may be treated as an adventure' (1978: 345). Not only that, he also contends that 'the meaning of death for individual human beings must be approached in the framework of the human condition as a whole' (1978: 346). While this can and maybe have to be understood as a perfectly legitimate formulation in the context of Parsons's scientific approach, it seems equally clear that the reasons why these arguments resonate more generally have also to do with their wider implications: the quest for the meaning of death lies in the interconnections between the individual and subjective, between the general and collective, between the transcendental and the organic, and between the continuities and discontinuities of historical time. It is as though Parsons is trying hard to make his scientific rationalism work also as a way of giving shape to the existential uncertainties that are built into our most fundamental human experiences: 'the positive acceptance of being human, with all its uncertainties and limitations, is not in the least incompatible with acceptance of both cognitive and attitudinal openness, which in one aspect is uncertainty, about many of the most essential features of the state of being human' (1978: 345). ${ }^{17}$

It is therefore no accident that questions dealing with life and above all death become normatively crucial for the sociologist: 'birth and death have constituted primary foci for every known human religion. Such problems seem to be at the very centre of the ethical problem of the human condition' (1978: 67, my italics). In the contemporary context, moreover, Parsons explicitly raises questions of abortion and brain death as among the most challenging ones to be faced by societies from a normative standpoint. $\mathrm{He}$ rejects essentialist positions that reduce human life to either its organic base or its spiritual content and instead takes seriously the dynamic duality of human beings that underpins AGIL. Fundamentalist claims that deny any legitimacy to abortion will become increasingly untenable, he says, because they reduce human life to one side alone. And the same

${ }^{17}$ Philosophically speaking, this tension between scientific and existential concerns seems to contaminate all forms of neo-Kantianism as apparent, paradigmatically, in Ernst Cassirer's work: while science is the most advanced way of achieving knowledge about everything in the world, the difficulty that remains is that, to the extent that the original human motivation to carry out science is existential and not in itself scientific, then science's highest position in the human spirit becomes something science itself cannot explain. See Cassirer (1972: 389-472; 2000) and also the discussion in Chapter 4. 
applies to brain death because, if 'an organism that continues to "live" at only the metabolic level [, it] may be said to be dead as a person' (1978: 349 , my italics). In other words, while the organic death of a living creature is not altogether unproblematic, ' $[\mathrm{t}] \mathrm{he}$ fate of the personality is, philosophically and theologically, far more problematical' (1978: 326). Scientific rulings over the organic continuation of life, however 'definitive' from their point of view, say little about its wider philosophical, normative or existential implications. Moreover, given the systematic expansion of life expectancy that we witness in modern societies for the first time in human history 'a greatly increased proportion of modern humans live out a full life course' (1978: 348). Again in this case, this matters both from the subjective perspective of individuals themselves and, in terms of evolutionary and demographic implications, from the standpoint of the species as a whole $(1978: 346,332) .{ }^{18}$

\section{III}

The concern with death and the general problem of the physical adaptation of the human organism to the natural environments lead us to what is arguably the field of empirical study to which Parsons devoted most consistent attention throughout his career. In an autobiographical essay that was first published in the early 1970s, Parsons comments that when, in the 1940s, he first decided to explore empirically questions of medicine, health and illness, this seemed to him the somewhat natural continuation of his early university studies in biology (1977: 33-40). He mentions Freud as a major discovery that then helped him in his subsequent conceptualisation of the psychological and organic aspects of human action. From a strictly sociological standpoint, it was the study of the work of health professionals, and what eventually became known as 'the sick role', that gave him the opportunity of gaining a deeper understanding of modern professions and bureaucratic institutions as a major dimension in the overall organisation of modern societies. In their functional specificity vis-à-vis other societal domains, in the particular kind of trust and normative commitments that are built into their professional roles, and also in the fact that their work is carried out within large and increasingly complex institutional settings, modern medicine offered itself as an ideal sociological laboratory for the study of modern societies (1964b). As he looked back on these early studies, Parsons's reflections

18 We will come back to abortion in Chapter 8, while in Chapter 4 we will also discuss how questions of intergenerational justice are vexatious because of the need to include an anthropocentric perspective at the same time that we have to move beyond it in order to accommodate those, possibly human, beings who have not yet been born. 
come ever closer to our interests in this book. He contends that health and illness are strongly connected to our definitions of human action; they are indeed 'paramount concerns at the action level' (1978: 72). He thus speaks of the vis medicatrix as that property of all living systems by virtue of which they 'have the capacity to cope, often without intervention, with disturbances to health or cases of illness' (1978: 66-7). What is unique about human beings is, therefore, the collective construction of roles and institutions that are directly oriented towards the adaptive handling of health and illnesses.

Sociologically, illness is defined as an institutionalised role that is characterised by three main properties: (1) being sick is not the patient's fault; (2) the sick are exempt from the duties of normal, everyday life; (3) collective measures ought to be taken for the sick to recover (1978: 21). On the one hand, this model is built upon the normative consensus that health is universally valued as positive, whereas illness is, equally universally, valued as negative: the patient and medical professionals are similarly interested in the ill getting back to a healthy state (1978: 74). On the other hand, the social roles thus constituted are built on the asymmetric power differentials between the sick person and health professionals (1978: 23-7). ${ }^{19}$ In these roles, moreover, doctor and patient are clearly distinguished from the other functions these individuals perform in other settings (1978: 75). Indeed, Parsons argues that looking at questions of health and illness underlies, again, the theoretical importance of the general relationships between integration and adaptation: for the case of humans, being alive is always and necessarily a dual natural and sociocultural challenge (1978: 20). Questions of health and illness have particular significance because they always and necessarily keep connected to both the organic and the normative aspects of social life:

The "dialectic," if one uses this term, of the relation between health and illness is, of course, bracketed within the still deeper set of dilemmas of the human condition concerning life, coming to the individual through human organic birth, and that channel alone, and the inevitable, though in timing and circumstances very uncertain, fate of individual death ... Health concerns the underlying conditions of the organic life of human beings, their biological births, their ultimate deaths, and the levels of functioning in between, but at the same time it concerns the problem of the meaning of this life and its vicissitudes. To squeeze out either aspect would be to vitiate the significance of the concept as a whole. $(1978: 79,81)^{20}$

19 This continues to be a contentious argument in the literature. See, for instance, Bissell et al. (2002), Burnham (2014), Frank (2013), Schilling (2002), Timmermans and Haas (2008), Varul (2010) and Williams (2005). For a historical account of the sociology of health and illness, and the role of Parsons's arguments in that development, see Gerhardt (1989).

${ }^{20}$ One consistently disappointing feature of Parsons's writing is the little understanding that he showed of the work of Marx (as apparent in the use of inverted commas in dialectic at 
The commitment to cooperation between the sick and health professionals is to be necessarily matched by the presumption of functional competence of the part of the latter with regards to prevention, care, mitigation and cure. But arguably more salient for us here is the fact that the particular fiduciary responsibility of health professionals is placed overtly and directly on concerns over life and death (1978: 25-6): the most basic of all adaptive requirements, the very continuation of life, is fundamentally connected to a set of normative expectations that in modernity have become fully institutionalised. The normative relationships thus constituted are not the moral attribute of a particular individual but something that occurs within a social context: this fiduciary responsibility is a fundamentally social property that emerges out of the highly regulated interactions that take place, within institutions, between the sick and health professionals. But however important this social side ultimately is, Parsons does not lose sight of the obvious here: illness, pain and suffering do have an 'organic reference' even if the organic cannot be automatically equated with the physical (1978: 68). Quite crucially, the organic includes the personality as well: '[j] ust as man himself is both living organism and human actor, who is a personality and social and cultural being at the same time, so health and illness are conceived, as human phenomena, to be both organic and socio-cultural' (1978: 81). The theoretical challenge is that of conceptualising health and illness as a social relation - they are roles that take place within specific institutional settings - while simultaneously allowing for the inclusion of their fundamentally organic dimensions. The theoretical solution to this challenge Parsons found it in what is arguably his most salient contribution to theoretical sociology sensu stricto: the theory of generalised symbolic media. ${ }^{21}$

Parsons's original idea for the theory of media comes from his early collaboration with Neil Smelser as they studied the relationships between society and the economy (Parsons and Smelser 1956). There, Parsons and Smelser developed a model of mutual interchanges between these systems that, a decade or so later, was developed in more systematic fashion. In several monographic papers that were first published in the 1960s, Parsons

the opening of this quotation). It is as though the ideological context of mid-twentieth century US sociology got the better of him, as he systematically refused to accept any insight from Marx. Apart from a single article, which is equally critical, Parsons mostly offered passing negative remarks on Marx's work (1967a). Yet the centrality of adaptation in his work, and indeed the special status he gave to the relationships between Adaptation and Integration, are in fact rather close to Marx's notion of the need of human beings to remain alive for society to exist.

${ }^{21}$ See Chernilo (2002). The next few paragraphs on the four media of the social system draw heavily on this article. 
(1967d, 1967e, 1969b) elaborated further on both the general framework of the theory of generalised symbolic media and the first definitions of each of the media for the case of the social system: money for the economy, power for politics, influence for the societal community and value commitments for the fiduciary system. It is worth remembering here that the theory of media has two sources: it draws, first, from the role of money in economic processes and, secondly, from the symbolic properties of human language. Although Parsons himself says that the theory was mostly developed as a generalisation from the properties of money (1977: 198-208), it is also the case that its wider applicability to the social system as a whole depends arguably to a greater extent on the properties of language. Indeed, the very name of the theory shows this basic tension: the idea of interchange refers to money; the ideas of generalisation and symbolisation are related to language. Let us briefly look at each media in the social system.

A. The function of adaptation belongs to the economic system, whose operations are ruled by the medium 'money'. This was the first modern subsystem to differentiate because the economy was historically first to achieve a high level of structural and institutional autonomy in relation to the other subsystems of society. As a generalised symbolic media, therefore, money is the standard that establishes the values that are assigned to all goods and services. The major institutions that ground monetarised economies are property, labour and contract. The value principle on which money operates is utility, that is, the specific rationality of the economic subsystem (1977: 188-9).

G. The function of goal attainment is fulfilled primarily by the political system, whose medium is 'political power'. Institutionalised authority is to politics what property is to the economy, and the value principle of power is effectivity, which refers to the amount of power that collectivities have at their disposal. The Parsonian concept of political power also includes 'legitimacy' as the binding character of the decisions done by power holders, but the conceptualisation of power as a medium presents the problem that there is not a clear measure with which to quantify the amount of power involved in any interaction. Physical force is the extreme case of use of power (1961: 53-4; 1977: 190).

I. The function of integration has its locus on the societal community and its medium is defined as 'influence'. Influence encourages the development of intersubjectively shared norms, and the production and renewal of social solidarity. Parsons says explicitly that the communicative strategy of influence is, unlike money, of a non-instrumental nature. Prestige and trust (say, in an opinion leader or the mass media) are the bases for social interactions mediated by influence and they are not necessarily subject to systematic rational justification (1977: 199). 
Table 3.3 Generalised media for the human condition, the action system and the social system

\begin{tabular}{llll}
\hline \hline Function & $\begin{array}{l}\text { Media in the human } \\
\text { condition }\end{array}$ & $\begin{array}{l}\text { Media in the action } \\
\text { system }\end{array}$ & $\begin{array}{l}\text { Media in the social } \\
\text { system }\end{array}$ \\
\hline A & $\begin{array}{c}\text { Empirical ordering (for the } \\
\text { physico-chemical system) }\end{array}$ & $\begin{array}{c}\text { Intelligence (for the } \\
\text { behavioural system) } \\
\text { Performance-capacity (for } \\
\text { the personality system) } \\
\text { organic system) }\end{array}$ & $\begin{array}{c}\text { Money (for the } \\
\text { economy) } \\
\text { Power (for } \\
\text { politics) }\end{array}$ \\
I & $\begin{array}{c}\text { Symbolic meaning (for the } \\
\text { action system) }\end{array}$ & $\begin{array}{c}\text { Affect (for the social } \\
\text { system) }\end{array}$ & $\begin{array}{c}\text { Influence (for the } \\
\text { societal } \\
\text { community) }\end{array}$ \\
L & $\begin{array}{c}\text { Transcendental ordering } \\
\text { (for the telic system) }\end{array}$ & $\begin{array}{c}\text { Definition of the situation } \\
\text { (for the cultural system) }\end{array}$ & $\begin{array}{c}\text { Value-commitments } \\
\text { (for fiduciary } \\
\text { institutions) }\end{array}$ \\
\hline \hline
\end{tabular}

Influence, then, should be anchored in feelings, values and traditions that are widespread among members of a group. ${ }^{22}$

L. The function of latency, finally, resides in the fiduciary system. Its medium of 'value-commitments' concentrates on the specification of values that can function as normative standards in different contexts of interaction within the system. Parsons talks of value-commitments, in plural, because there are different values that can be expressed in society, and the medium helps to give priority to some values over others. Valuecommitments provide legitimacy to the functions of the remaining media of the social system (1969b: 456). Table 3.3 summarises the key media for each of Parsons's major levels of analysis: the human condition, the action system and the social system.

In relation to the theoretical evolution of the theory of media, Niklas Luhmann is usually credited with having made an explicit argument on the need to conceptualise not only their symbolic but also their symbiotic dimension. Because Ego and Alter share a physical world, Luhmann contends that at least part of the evolutionary success of some media, that is, their thorough institutionalisation, depends on the compatibility between the symbolic and the organic dimension of each media: the higher the capacity of utilisation of the symbiotic mechanism, the better the performance of the subsystem (Luhmann 1977, 1995: 244-54). Thus,

${ }^{22}$ In this sense, the medium influence can be seen as a partial instantiation of the kind of communicative rationality that is necessary in a democratic public sphere and civil society. See Cohen and Arato (1992: 118-42), and Habermas (1987: 179-97, 256-82; 1996: 329-87). See also Chapter 5. 
for instance, physical force is the symbiotic mechanism that underpins politics, the satisfaction of basic material needs offers the organic basis for the economy, visual perception operates as the basis of science and sexual desire underpins the differentiation of family life and the private sphere. One of Luhmann's key contributions is therefore that of having paid explicit attention to those particular mechanisms that are neither strictly social nor exclusively organic; rather, they have the ability to connect the two in the human body.

To Luhmann, the inclusion of symbiotic mechanisms not only safeguards but actually reinforces his key contention that only communications belong in the social system: his theory of media is one of communicative media. But what is interesting for us here is that Parsons argues in precisely the opposite way. In his writings on both medicine and the human condition, Parsons states that health and illness cannot be seen as exclusively social media; on the contrary, they are to be treated as media because they are not purely symbolic (1978: 328-9). It is precisely because they are both social and organic that health and illness are defined as a generalised media of 'interchange' (1978: 71). Health and illness are directly and simultaneously connected to the physical, organic, psychological and sociocultural worlds (1978: 69). Even more relevant from a theoretical point of view, the claim is now put forward that it is the absence of a symbolic dimension that allows for their translation into the various codes of the different subsystems. Parsons presents his argument thus:

health may be conceived as circulating, within the organism, within the personality, and between the personality and the organism. From this point of view, good health is an "endowment" of the individual that can be used to mobilize and acquire essential resources for satisfactory functioning as organism and personality. Health, in this meaning, would function only if it is "used" and not "hoarded."

When conceived as such a medium, health stands midway between the action level media such as money, power, and language and the intra-organic media such as hormones and enzymes. (1978: 80)

As he moved forward in the development of an explicit 'philosophical anthropology', Parsons became increasingly aware that three critical dimensions of his 'sociology' were in need of revision. These are also the key contributions that we take from him for the project of a philosophical sociology:

- However sophisticated or comprehensive, a purely scientific approach is inadequate for the purposes of understanding the human condition, which requires also that we pay attention to the more normative or 
existential motivations that lead human beings to raise these questions at all.

- The anthropocentric perspective that had been systematically described as an obstacle for the development of the modern scientific imagination is now treated as condition of possibility for the successful conceptualisation of the human condition itself.

- While the symbolic aspect of social relations remain a fundamental dimension of the human condition, any adequate understanding of it requires the explicit inclusion of the physical and organic dimensions of human life.

Methodologically, the main challenge for Parsons was to develop an approach for the study of the human condition that was able, simultaneously, to retain the level of abstraction of AGIL and look at it from an anthropocentric point of view. The need for this dual external and internal accreditation is a unique challenge in the study of the human predicament: we inhabit a world that we have not created, but we can only attempt to make sense of it from the inside out.

Parson's idea of adaptation matters to the project of a philosophical sociology because, while it focuses on the relationships between our organic constitution and the natural environment, it does not do so from a reductionist point of view. This is precisely what medicine, and his concomitant conceptualisations of health and illness, offered Parsons: a way of looking at the various ways in which our bodily constitution works as a focal point for the complex web of personal, social and cultural domains that constitute our human existence. Parson's multi-layered idea of adaptation works because it systematically includes all those domains. 
The discussion of the philosophical work of Hans Jonas has the apparent shortcoming that there is little in his work that we can describe as fundamentally social or explicitly sociological. To the extent that social relations figure in his writings, they remain subordinated to his primary philosophical concerns with ideas of 'being' and 'nature' - not least human nature. The strictly 'intersubjective' dimension of human life, as it emerges in his writing through such questions as reflexivity, science and obligation, are always dependent on arguments that go back to humanity's biological grounding in the natural environment. And when social relations do figure in his argument, they do so in the context of the political side of his thinking on technology and democracy; namely, how are we to create the social conditions that make possible the imperative of responsibility that current citizens of world society have towards future generations. But these issues are explicitly introduced as part of his applied ethics, whose philosophical status is secondary vis-à-vis the foundational questions he addressed more systematically. Jonas thought that his main philosophical contribution lay in the development of a philosophical biology as a chapter in the development of a new metaphysics rather than in the potential practical contribution of any such philosophy: 'any discussion of my philosophy should begin ... with my efforts to establish a philosophical biology' (Jonas 2008: 65). To that extent, his work is unique among those I am using in this book to develop a philosophical sociology: instead of having a more or less fully developed theory of society that depends on a fairly unarticulated idea of the human, Jonas's work focuses mostly on the latter and pays little attention to the former. ${ }^{1}$

This apparent lack of interest in the question of 'what is the social' is relevant for my project of a philosophical sociology because Jonas

${ }^{1}$ Jonas even complained, although half-heartedly, that the public success of his Imperative of Responsibility (1984) had more to do with circumstances and context-global warming and the rise of Green politics in Germany in the 1970s - than with any serious consideration of what he thought was his most original contribution; namely, the ontological arguments that give rise to his ethical naturalism (2008: 205). 
contends that, in order to understand the normative we must explore the non-social foundations of social life. One way of looking at his work would be to claim that he turned the relationships between sociology and philosophy upside down: while from a conventional sociological perspective the social is an explicit concern and human nature is treated as a residual category that is defined mostly negatively, the opposite is the case for Jonas: the human now takes centre stage and the social becomes the 'transcendental' background within which ideas of human nature become explicitly articulated. He is interested in humanity's relationship to nature and these reflections are made without explicitly conceptualising society as the medium through which humanity interacts with nature. Society remains that unnamed space that makes possible the realisation of human nature, including the human ability to reflect on human nature, but its key features are not subject to formal conceptualisation. It is this counterintuitive aspect of Jonas's work that warrants his inclusion in this book.

While ethical naturalism would be a straightforward way of characterising Jonas's position, his work has also been described as seeking to offer an existential interpretation of biological facts (Vogel 2001: xi). As we mentioned in Chapter 1, much of Jonas's philosophical arguments are explicitly informed by a critique of his mentor, Martin Heidegger. At a personal level, Jonas was deeply disappointed and never forgave Heidegger's endorsement of Nazism; indeed, it is the continuous lack of remorse that troubled him the most. But it is philosophically, however, that Heidegger's political failures to understand the true colours of Nazism become more consequential. Jonas contends that this radically challenges the purpose of philosophy as a whole: what is really the point of philosophical knowledge, personal genius and intellectual originality when the most basic moral and political intuitions abandon the philosopher as a person? (2001: 247-9). ${ }^{2}$ There is then one normative sense in which Jonas's work is not only critical but directly opposed to the historicist, irrationalist and indeed elitist implications of the 'existential philosophy' as advanced by Heidegger. As it comes out of his own historical-philosophical research on the origins of Gnosticism since the fourth century BC, Jonas (1963) contends that the gravest category mistake of twentieth-century existential philosophy lies in the centrality it gives to 'nothingness'; that is, in how it relishes in the notion that life

${ }^{2}$ See Wiese (2010: 87-98) and Wolin (2001: 101-33) for further discussion of the relationships between Jonas and Heidegger. 
has no ultimate purpose or meaning. ${ }^{3}$ The main consequence of this distorted view of the cosmos, Jonas contends, lies in human beings' belief that they themselves lack any significant relation with the world that surrounds them. Jonas sees this insistence in nothingness as little more than a dogmatic presupposition that 'springs from the denial of "essence" which blocked the recourse to an ideal "nature" of man, once offered in his classical definition by reason ... or in the Biblical one by creation in the image of God' (2001: 47). By denying the possibility of making meaningful connections between personal existence and the world around us, between humanity and nature; indeed, by dogmatically asserting that any philosophy that entertains this as a possibility has already discredited itself as a viable philosophy, Heidegger's existentialism shows above all its own reductionism and lack of genuine philosophical openness.

Existentialism is not however exhausted in Heidegger's version and we have seen that, in his polemics with Sartre, Heidegger disowns the term altogether. Existentialism can be retained however if we allow for an interpretation that focuses instead on the possibility of establishing a positive relationship between human and other forms of life. Jonas's existentialism then focuses on the ways in which the particularity of our human experiences of the world is grounded in our organic belonging in nature. This organic constitution is something that we share with other human beings but also, and more generally, with all other forms of life. Nature and life then become the fundamental categories that name both existence in general and our particularly human relationships with the world. Nature means life and life is the common form of being that humans share with all other creatures: nature is the transcendental framework within which all creatures experience the world.

Jonas's ontological starting point is that, however incipiently, all living organisms have an identity that results from their active 'self-integration'. Regardless of their degree of complexity, as long as they remain alive, and because they are alive, organisms look after themselves and pursue the maintenance of their existence as their own 'continuous achievement' (2001: 80). Organic life is thus understood as 'the first form of freedom' and it is this freedom that strives for continuous existence, the one Jonas

${ }^{3}$ Hans Blumenberg (1987: 25-6) captures this as, following Jonas, he perceptively defines Gnosticism as a 'radical anthropocentrism combined with a negative characterization of man's position in the cosmos' (my italics). Eric Voegelin (2000) offers a comprehensive discussion of Gnosticism as the defining feature of modern times: the treatment of all transcendental speculation as illegitimate because the existence of the transcendental itself is negated. Further discussion of Gnosticism is available in Chernilo (2013a: 59-69) and Lazier (2003). 
defines as the essential form of identity that constitutes life itself (2001: 3). In an inversion of the conventional Kantian proposition that freedom and necessity oppose one another, Jonas contends that freedom requires necessity and only as we see the two in their relationships are we also able to appreciate what it means for an organism to $b e$ alive. Life is then defined as that active principle that 'stands in a dialectical relation of needful freedom to matter'; life comprises freedom as the organism's capacity 'to change its matter' while, at the same time, it includes 'the irresistible necessity for it to do so' (2001: 80 and 83).

This quasi-transcendental position of nature and life in Jonas's philosophy finds further expression in the paradox that lies at the centre of the metabolic constitution of all creatures: organisms employ various means to remain alive, but living creatures modify their ends because the means themselves become central to the continuation of life as their own ultimate goal (2001: 106). At its most basic level, therefore, human nature is not qualitatively different from any other type of organic life - however simple. Indeed, even human 'sociality', the fact that the realisation of the organic potentials of some species requires the company of and association with others, is not specifically human. The actualisation of an organic potential may well require that certain species live within a collective environment, and this sociality remains something that organisms ought to do because it is in their nature: even as they have a natural impulse to sociality and their inner impulses are forcefully directed to sociality - as in the case of bees and ants - the source of these tendencies are previous to it.

Through this emphasis on the self-organisation of life, the reciprocity between freedom and necessity, and also the pre-social sources of all forms of sociality, some family resemblance seems to emerge between Jonas's ethical naturalism and such approaches as cybernetics and functionalism (see Chapter 3). At one level, this may be inevitable because Jonas is explicit in his contention that, for his philosophical thinking on nature to be plausible, it must remain up to date with the most recent developments in the natural sciences and its epistemological debates. But the similarities end there, because Jonas is highly critical of how modern cybernetics understands nature as an inert order and explicitly extracts out of it all possible metaphysical or existential implications (2001: 108-34).

According to Jonas, modern science is based on two major intellectual traditions that, quite rightly, ground human existence in nature in a way that is analogous to other living species. Materialism and evolutionism both share a number of features in how they understand nature; they see it as self-contained (only nature creates nature), lifeless (organic matter produces life but matter itself is inert) and purposeless (nature responds to no 
teleological plan). There is no question that materialism and evolutionism are here to stay and that there will be no regression to 'pre-scientific' forms of treating nature. Nature is a valuable resource, it has no ultimate purpose and all forms of life possess some degree of organic continuity. But Jonas also contends that the success of this general ontology of nature is pragmatic rather than philosophical; that is, modern societies hold onto it above all because of the technological success of modern science. But together with praising science's practical strength, Jonas contends that, as a form of metaphysics, the scientific representation of nature bears a fundamental contradiction. Another implication of Jonas's existential understanding of biological facts becomes fully apparent now: what makes materialism and evolutionism metaphysically deficient is the claim that the cosmos is wholly inert; rather, we need to understand nature as populated by beings whose continued existence is valuable for themselves. This does not mean that we need a discernible cosmic plan for nature, but his argument does reject any notion that nature as a whole, and different forms of life within nature, are there for humanity's sake. To the extent that self-preservation is an end for each individual living being, they are all ends in themselves. Indeed, Jonas treats all living organisms as individuals in this strong sense (1980b: 187). Because they exist and in so far as they continue to exist, all forms of organic life are open to a principle of individuation and identity that takes itself as its own foundation and thus becomes its own value. The continuation of life has a subjective value because it is the primary concern for living beings themselves (2001: 61). This is a type of subjective relevance that is independent from human subjectivity and it is this very independence that makes it truly general. Because it is general, this subjectivity becomes objective and the continuation of life is now to be seen as a self-positing objective value. At the most general level of his philosophical project, therefore, Jonas has positioned himself against any version of anthropocentrism.

As a different ontological understanding of nature, and of organic life within nature, begins to emerge, this alters also our normative understanding of nature. If the pragmatic grounds for modern science to have adopted the interpretation of inert nature are understandable in terms of instrumental success, this interpretation has already proved philosophically unsound. As self-preservation is key to all living creatures, and their continued existence is what they themselves prefer, the question we now need to raise is the purposiveness of life itself; in other words, we ought to seriously reconsider the 'capacity to have any purposes at all as a good-initself'. But unless we want to affirm 'the paradox of a purpose-denying purpose, $[\ldots w e . .$.$] must concur with the proposition that purpose as such$ is its own accreditation within being, and must postulate this as an 
ontological axiom'. This view, Jonas contends, is 'infinitely superior to any purposelessness of being' (1984: 80). Philosophically, this offers a more consistent approach to nature because it acknowledges that nature is populated by all kinds of living organisms; normatively, this allows for a standard that can be used to critically assess the anthropocentric belief that we humans have an unrestrained right to use nature as if it were wholly devoid of value and even life itself.

Jonas speaks of self-preservation as a natural feature that applies to all living creatures but qualifies this by claiming that, for most living species, self-preservation has other members of their species as a primary and even exclusive locus. In the case of humans, grasping the uniqueness of our own life in the form of self-preservation requires the human ability to transcend a self-centred perspective; more precisely, humans are themselves organically pre-programmed so that they are able to adopt the perspectives of others - both within and outside our own species. Life's concern with its own continuation means that it 'is facing forward as well as outward and extends "beyond" its own immediacy in both directions at once' (2001: 85). A theme that we have seen appear also in Chapter 2, Jonas contends that the immanence of human life is constituted through its continuous attempts, indeed the need, to transcend the here and now of biological grounding. The organic basis of metabolic existence, its terminus a quo, has always and necessarily to do with basic needs - e.g. the postponement of immediate gratification and the ability to plan for their long-term procurement - but its goal, its terminus ad quem, has much more to do with the co-presence of various other beings with whom we share a physical environment. But if humans share with most living creatures this tension between a self-centred organism and their need for the presence of other members of their own species, Jonas contends that only humans have the ability to turn organic 'self-centrism' into a systematic ability for decentring. From the family to the state, from law to science, social institutions develop as a way to protect and foster life as a whole. As we will see below, moreover, it is this ability that requires humans to take a particular kind of responsibility. ${ }^{4}$ Not dissimilar to Karl

${ }^{4}$ Richard Wolin's (2001: 115-16) remarks that Jonas's focus on self-preservation turns his work into a form of neo-Hobbesianism is therefore wholly off the mark. First, because here self-preservation has a fundamental existential justification that is alien to Hobbes's mechanistic individual psychology; second, because Jonas's notion of self-preservation does not translate into competition or domination and, depending on the specificities of various living creatures, it may equally centre on collaboration and cooperation and, third, because it is wrong to claim that Hobbes's own metaphysics centre only on selfpreservation (Chernilo 2013a: 97-107). In fact, because the ultimate orientation of his work depends on the co-constitution between being and purpose, it is more adequate to locate Jonas's philosophy within an Aristotelian tradition. Indeed, references to Aristotle 
Löwith's (1964) thesis on the religious roots of most secular and scientific concepts, Jonas critically remarks on the ideas of the human that we moderns have inherited. But in Jonas's case he emphasises the implicit anthropocentrism that characterises the normative underpinnings of modern societies: '[ $\mathrm{t}$ ] he deus absconditus [hidden god], of whom nothing but will and power can be predicated, leaves behind as his legacy, upon departing the scene, the homo absconditus, a concept of man characterized solely by will and power - the will for power, the will to will' (2001:216). Indeed, not only man's relation to nature is conceived of as one of power but, as we have seen, 'nature herself is conceived in terms of power' (2001: 193). Homo faber, modernity's most prodigal son, seeks to take control of the world - including control over human nature. The instrumental aspect of modern technology has then been wrongly turned into the key anthropological feature that characterises our relationship with both external nature and other humans $(1984: 9,168) .^{5}$

The pragmatic strength of modern science on the basis of its predictive capacity and the instrumental success of technology have completely taken over questions of epistemological and indeed ontological consistency, which were of exclusive philosophical resort up to Hegel's time (Schnädelbach 1984). Jonas confronts this diminished status of philosophical knowledge by returning ever more decidedly to metaphysical questions; his is an attempt at the renovation of a first philosophy that redefines our very conceptions of nature and humanity. There is a sense in which, while traditional and modern images of the human being have dissimilar ontological groundings, they are equally faced by the challenge of having to become compatible with the wider ontologies that frame all realms of human experience: the natural, the social, the individual and even the divine or transcendental. Indeed, the clashes between these metaphysical presuppositions at various levels have been a major mover in both philosophical and scientific innovations - the development of a new 'metaphysical point of view is not only the effect but also the cause of a scientific development' (2001: 70). In Jonas's argument, the required revisions to ontologies of inert nature will allow us to see nature, instead, as a source of value in its own right because living creatures themselves prefer their own continuation. If this is the case, we are now also able to recast the relationships between ontology and axiology - which are the old terms for what we, in the social sciences, discuss under the banner of 'facts' and 'values' or 'description' and 'normativity'.

are constantly found in his work $(1984: 69,204 ; 2001: 2,86)$ even if, in fairness, Jonas did object to his work being depicted as neo-Aristotelian (2008: 204).

${ }^{5}$ See, in the Introduction and Chapter 8, a similar critique for the case of Pierre Bourdieu. See also (Chernilo 2014). 


\section{II}

Jonas claims that there are objective grounds (i.e. ontological reasons) for normatively preferring being over non-being: 'existence per se, no matter of what kind, "ought" to be in preference to nothingness'; there is both 'preeminence' and 'obligation in favor of being' (1984: 46). If this is the case, we can break the modernist taboo that radically separates the is from the ought as the cornerstones of modern philosophy: 'the good or valuable ... is by its very concept a thing whose being possible entails the demand for its being or becoming actual and thus turns into an "ought"' (1984: 79). Values exist both objectively - they derive from the autonomous existence of beings who are, that is, whose ontology is a fact of nature - as well as subjectively - these are beings for whom their very existence requires them to treat their own lives as a value. Because they exist, and their existence is a value for themselves, living organisms ought also to exist: a normative principle does follow from a primary statement of fact. Jonas changes the way in which we connect description and normativity so that the normative is now pursued on the basis of a reconsideration of the objectivity that is founded in our organic belonging in nature. Not only this, Jonas contends that, after various critiques of ideas of historical progress, revealed religion and even racial purity, this naturalistic argument remains the only available option for thinking about binding normative propositions. What started as a general enquiry into the relationships between ontology and ethics has now a direct bearing in the way we redefine the normative underpinnings of any possible principle of humanity: 'our ethical-metaphysical query about an ought-to-be of man himself in a world that ought to be, turns into the more specific and much less speculative question of the logical and ontological status of values as such' (1984: 50).

We can see here that Jonas's ontology stands in opposition to the nihilism that in his view underpins Heidegger's philosophy. In Heidegger, human worthiness is fundamentally passive and derivative, as it is fundamentally a response to the external and indeed superior calls of being, whereas any kind of anthropology is inadequate because it bases a claim to knowledge on humanity's organic features. Jonas has effectively turned Heidegger on his head. There is nothing mysterious or elitist in his idea of being, which is on the contrary based on the radical egalitarianism of organic life. Jonas reclaims a value for nature and, in so doing, explicitly seeks to close the gap between subjective and objective axiological claims. Nature is a source of objective normative value that can help us transcend both the subjectivity of values as mere preferences and an instrumental conception of value as means to an end. To Jonas, this form of ethical naturalism becomes the only normative position that remains available in modernity because it is 
based on the objective self-positing of organic life that is also credited subjectively. Organic life is the only fact of nature we know with certainty; it is, therefore, the only one that we can posit in terms of an unconditional normative obligation because we are equally aware of it from the inside and the outside. Even if it has not been fully justified yet, Jonas's fundamental argument has at least been made: his project of a philosophical biology is designed to help us reconnect facts and values because nature has unique authority in sanctioning values objectively as well as subjectively:

Ontology may yet to relocate the foundation of "ought" from the ego of man, to which it has been relegated, to the nature of being in general. It may have been premature despair which denied the doctrine of being the power to yield a ground of obligation - for beings, of course, that are previous to obligations, and who must be there so that obligation can find its respondent. (2001:283)

We have said that no return to a pre-scientific metaphysics of nature is acceptable for Jonas, so his challenge to the ontological commitments of modern science must itself remain scientifically current: whatever else philosophy may be able to criticise science for, scientific developments will not stand still or wait for philosophy's authorisation (2001: 209). The development of this new outlook requires a dual move. First, modern social scientists need to accept the centrality of an idea of nature that radically questions the proposition that social and cultural reality is only socially and culturally construed. For obligatoriness to be truly obligatory, contends Jonas, it cannot be just socially constituted: '[t] hat which has no nature has no norm' (2001:228). As traditional forms of authority have been eroded, and because not everyone has subjective access to divine authority, then only nature remains available to take that normative place. Second, natural science will have to be accommodated within a wider philosophical perspective that, among other things, is able to explain science itself: 'as an occurrence within the universe which undertakes to explain, [science] is forever excluded from what $i t$ can explain. Its own existence is indeed its own best corrective' (1984: 72). ${ }^{6}$ What is missing in the scientific account of nature, and indeed from a scientific understanding of scientific knowledge itself, is for Jonas the subjective impulse that makes science a human project: the motivation that leads individual scientists to pursue science, the inner drive that pushes human beings to pursue projects that are purposeless vis-à-vis their physical adaptation to the world and are also endless vis-à-vis any sense of definitive accomplishment. For scientists, the very rationality of their pursuits requires them to accept that there is some autonomy in their

\footnotetext{
${ }^{6}$ See also Habermas's discussion in Chapter 5.
} 
thinking so that they are able to discern between competing theories or contradictory empirical evidence (1984: 70). The price we pay in denying this possibility is that reason itself becomes an 'irrational entity' and 'intelligence' becomes 'entirely unintelligible within the intellectual scheme of the scientifically knowable' (2001: 73-4). The commitments to freedom, truth or beauty that are an essential component of the modern scientific imagination are themselves extra-scientific; they cannot be apprehended by reducing them to causal relations between, or the organic properties of, inert nature.

This concern with the position and main features of modern science in society was of course central to Jonas's own philosophical education. On the one hand, the positive assessment of science as the model to which a true objective philosophy must duly aspire - a position that, all their differences notwithstanding, was shared in the first part of the last century by Husserl's (1970) phenomenology and the neo-Kantian movement that was represented, for instance, in Ernst Cassirer's (1972) work. On the other hand, there is the philosophical rejection of science on the grounds of its blockage to the authenticity of existence (Heidegger) and also because of the selfdestructive potential of its technological application in terms of instrumental rationality (as in the critical tradition of Adorno, Fromm, Horkheimer or Marcuse). While highly critical of the shortcomings of scientific metaphysics and of the excesses of scientific civilisation itself, Jonas remains equally distant from these two opposite views about contemporary science. Also important is his scepticism concerning the idea that the human and social sciences are to be modelled upon the natural ones:

For a scientific theory of him to be possible, man, including his habits of valuation, has to be taken as determined by causal laws, as an instance and part of nature. The scientist does take him so - but not himself while he assumes and exercises his freedom of inquiry and his openness to reason, evidence and truth. Thus man-theknower apprehends man-qua-lower-than-himself and in doing so achieves knowledge of man-qua-lower-than-himself-man, since all scientific theory is of things lower than man the knower ... man-lower-than-man explained by the human sciences - man reified - can by the instructions of these sciences be controlled (and even "engineered") and thus used. (2001: 196)

The inconsistency Jonas points out in this quotation is central to my idea of philosophical sociology: as autonomy and creativity are being granted to the scientists as they pursue their work as scientists, they are however denied to the human beings who are the subjects of these scientific studies. Far from being objective, the kind of knowledge thus produced is then inferior vis-à- vis science's own scientific standards: it appears to be adequate or even complete only because they are being assessed against too narrowa conception of what counts as genuinely human behaviour. 
Similar to the criticism of homo sociologicus we discussed in the Introduction, Jonas's point here illustrates one additional dimension: the very scientists that produce these reductionist accounts of human action are, in their work as scientists, a refutation of the principles that they espouse. In terms of his critique of the social sciences, human originality is being eroded as part of the homogenising trends of mass society - again, the very trends that are being studied by 'positivistic' social science. In terms of his critique of the natural sciences, human originality cannot be accounted for as part of a mechanistic conception of nature.

Given its reductionist understanding of what may count as human in our lives, a purely scientific, pragmatic or hypothetical attitude is insufficient. A key part of the problem lies in the fact that the success of their theoretical models as sciences are based on the rejection of transcendence as a meaningful domain of intellectual enquiry; the possibility of 'objective transcendence lies today outside theory by its rules of evidence, whereas formerly it was the very life of theory' (2001: 185). Partly building on Kant, Jonas comments that transcendence 'implies objects higher than man, and about such was classical theory'; on the contrary, 'modern theory is about objects lower than man' (2001: 195). But then Jonas takes issue with the Kantian defeatism of rejecting the possibility of a rational metaphysics. In order to reascertain the possibility of metaphysics, however, we need to reconnect a principle of humanity with the ontological demands of naturalism as they emerge out of Jonas's position. The rationality of metaphysics, Jonas contends, can be reinstated on two grounds that we have already encountered in this discussion: on the one side, the anti-Heideggerian motif that the existence of 'anything at all' is in itself a reason to argue 'why a particular something ought to be' (1984: 43). On the other side, a theme that is equally constitutive of the whole tradition of philosophical anthropology: the problematic centrality of anthropocentrism in ethical thinking: '[o]nly the idea of Man, by telling us why there should be men, tells us also how they should be' (1984: 43). It is then one thing to contend, as materialism and evolutionism do, that human beings are simply yet another kind of living creature and quite another, Jonas suggests, that several of our human accomplishments represent a real upgrade on nature. A question that remains, however, is the extent to which Jonas's criticism of the modern scientific attitude takes his own ethical naturalism as an exception. Jonas's argument is that, because his philosophy of nature redefines life, no mechanicism is to be found within his work. But something rather naive, indeed troubling, remains in his direct appeal to the normative forces of nature. 


\section{III}

The starting point of Jonas's critique of anthropocentrism is that human beings cannot be conceived anthropomorphically because they are little other than an accident of nature. It is the greatest paradox of that accident, however, that humans have developed the skills and institutions that make them able to reflect on their position in nature and, given these special features, also take responsibility over nature (2001: 233). In so far as his critique of anthropocentrism is concerned, Jonas is interested less in a conception of human being as a key object of concern for itself - we have seen that this is in fact the way in which all forms of life organise themselves - and more in the rejection of a conception of nature whose only value resides in its instrumental availability for human being: humans are an object of nature rather than their master. Humans are not the measure of all things but our particular species-centred perspective has the unique ability to understand the workings of nature. Consciousness is a specifically human accomplishment as humans make images and are then able to distinguish them from the real thing; humans have the 'ability to perceive likeness' and 'whoever can perceive a pictorial representation as such is the kind of being to whose nature the representational faculty belongs' (2001: 165). A key feature of the specific relationship between humans and nature lies in the former's ability to name things in the world; humans move beyond the animal kingdom by making things and then representing them symbolically (2001: 173).

These are the skills that delimit the specificity of the ethical imperative of human existence: only humans can take responsibility for the rest of nature because they have the power to do so. It is 'the scope and kind' of human powers that 'determine' the kind of responsibility they have on their shoulders and this remains a responsibility that falls only on humans (1984: $98,128)$. Jonas's critique of anthropocentrism, the self-centred concern of our species only with ourselves, has to be made compatible with our equally unique anthropological capacity for transcendence. There is, however, a tension in this argument. We must, first, be prepared for 'a hesitant emergence of transcendence from the opaqueness of immanence' (2001: 275): the overcoming of narrow anthropocentrism is available to humans insofar as they raise general existential question. The relationships between ability and responsibility are now to take centre stage in Jonas's thinking, and we have seen that his redefinition of nature was expected to do the philosophical work in that direction. And yet, second, he himself raises doubts as to whether claims to fully transcend anthropocentrism are to remain an ideal at best: '[p]erhaps, rightly understood, man is after all the measure of all things - not indeed through the legislation 
of his reason but through the exemplar of his psychophysical totality which represents the maximum of concrete ontological completeness known to us' (2001: 23).

Normative intuitions that refer to what we treat as intrinsically valuable, good, true, beautiful or just are central to how humans imagine, justify, assess and criticise the variety of ideas, practices and institutions that they themselves create even as they confront them as external. Stated positively, the claim is that the ontological grounding of ethics refers back to images of the human (1984: $\mathrm{x}$ ) but, stated negatively, it becomes the methodological suggestion that by anticipating the 'distortions' in our conceptions of the human we can detect the normative challenges we are about to face: 'we need the threat to the image of man - and rather specific kinds of threat - to assure ourselves of his true image by the very recoil from these threats' (1984: 26-7). The normative strength of various normative ideas derives from their answers to the question of what makes human beings human:

Man models, experiences, and judges his own inner state and outward conduct after the image of what is man's. Willingly or not he lives the idea of man - in agreement or in conflict, in acceptance or in defiance, in compliance or in repudiation, with good or with bad consciousness. The image of man never leaves him, however much he may wish at times to revert to the bliss of animality. To be created in the image of God means to have to live with the image of man. That image is worked out and entertained in the verbal communication of society. (2001: 185-6, my italics) ${ }^{7}$

At one fundamental level, all modern sciences are in a similar position to previous (religious, mystical) forms of human thought in terms of their being sustained upon implicit, inconsistent and even reductionist images of the human being. In science, these are now referred to as ideas of 'human nature' and the full development of the different implications of a new metaphysics of nature and man is the ultimate goal of Jonas's philosophical biology. The very notion philosophical biology is surely inspired by that of philosophical anthropology: first, because of the way in which Jonas engages with both the organic and spiritual aspects of human life; second, as a rejoinder to Heidegger's rejection of the idea of looking at the human from the standpoint of their organic dimensions. But we have seen that Jonas also tries to break free from one of philosophical anthropology's key presuppositions; namely, the reductionist aspects of modern anthropocentrism. Philosophical biology picks up the problems philosophical anthropology has left for us by taking seriously

${ }^{7}$ Through this reference to the idea of 'the image of god', the extent to which Jonas's philosophy emphatically presupposes a conception of the divine becomes apparent. I come back to this at the end of the chapter. 
the centrality of humans for humans themselves but, at the same time, it turns that centrality into an ontological or indeed normative principle. Neither philosophy nor science can, on its own, give a full account of the human being, not least because we are at pains to understand how exactly we are going to be able to combine their different knowledge-claims: it is just futile, argues Jonas, that we merely have 'a philosophy of man on the one hand and a philosophy of nature on the other' (2001: 92). Philosophical biology seeks the ontological reintegration of an idea of nature that is consistent with developments in natural science and can thus aspire to account for both continuities and discontinuities between human life and life in general: '[i]t is the task of a philosophical biology to follow the unfolding of this germinal freedom in the ascending levels of organic evolution' (2001: 83). Philosophical biology is expected to 'deal with the organic facts of life, and also with the self-interpretation of life in man' (2001: 6, my italics). All his arguments for organic egalitarianism notwithstanding, humans remain the most accomplished living creatures. ${ }^{8}$

Building on his previous argument on the ontological and normative priority of being over non-being, Jonas will now claim that the continuation of human existence in the planet, alongside the continuation of a planet in which human life remains itself possible, are ethical questions that need to be treated together. Now it is human life rather than life in general that is at stake, and here Jonas has moved, from general axiology and first philosophy, to the narrower field of applied ethics. The argument is that human beings have normative challenges not because of anything particular that they do in the world, nor on the grounds of an external (e.g. divine) imposition: normative questions are an immanent result of their human existence in the world. More concretely, he argues that although for much of human history nature's continuous life could be taken as 'unquestionable given' we now live in an age in which its continuation has 'become an object of obligation' (1984: 10). If existence is the selfimposed normative goal of all living creatures in relation to themselves, for humans this now applies to their responsibility towards the planet as $a$ whole. We have seen that the sources of this obligatoriness are not intrinsically modern; they are a metaphysical demand that derives from human existence itself. But given the scale of technological innovations and environmental challenges that are a direct result of human intervention, this responsibility has now dramatically intensified and become the major social question of our times. ${ }^{9}$ The impact of technological changes

${ }^{8}$ Further critical discussion of Jonas's idea of philosophical biology is available in Mitcham (2010) and Wolters (2001).

${ }^{9}$ I have applied Jonas's arguments to recent debates on the Anthropocene in Chernilo (2017). 
has reached the whole globe and their consequences are to be felt for the foreseeable future; indeed, they are to be felt well beyond the lifespan of those currently alive (1984: 6-8). There is now a clear possibility that we are ruining the natural environment not only in relation to other species in the present but also for future humanity: at stake here is the question of the continuation of all forms of life on earth. But if the temporal extension of the effects of modern technology has changed our way of inhabiting the world, our ethical thinking is yet to change accordingly (1980a). For all his effort in trying to justify the philosophical foundations of his position, Jonas contends that it is above all the pragmatic urgency of environmental challenges that makes them relevant. Even if we fail to agree on such foundational questions as a common conception of the human, nature or life, these polemics are secondary to the practical and political demands of the world we live in:

we find ourselves thrown back from the ever-open question, what man ought to be (the answer to which is changeable), to the first commandment tacitly always underlying it, but never before in need of enunciation: that he should be - indeed, as a human being ... what now matters most is not to perpetuate or bring about a particular image of man but first of all to keep open the horizon of possibilities which in the case of man is given with the existence of the species as such and [which] will always offer a new chance to the human essence. (1984: 139-40)

Jonas's imperative of responsibility then states that our actions in the present ought to secure the continuation of human life in the future. We have the duty to leave the planet in a state that is worthy of human habitation, a planet that allows future human beings to lead a fully human life. More precisely, we owe future generations the conditions that make possible human life as a self-legislating experience: conventional ideas of self-preservation now need to be widened in order to include the future existence of human beings. Jonas's argument seems to go back to the same kind of anthropocentrism that he had rejected, but it is important to remember that he is no longer arguing at an ontological or axiological level. As an argument of applied ethics, his position is that the better we are able to look after the future of humanity, the better will humans also be able to look after nature itself. Formulated as a moral law, Jonas introduces his imperative of responsibility thus: 'there ought to be through all future time such a world fit for human habitation, and ... it ought on all future time to be inhabited by a mankind worthy of the human name' (Jonas 1984: 10). ${ }^{10}$

${ }^{10}$ An alternative formulation is 'that no condition of future descendants of humankind should be permitted to arise which contradicts the reason why the existence of mankind is mandatory at all. The imperative that there be a mankind is the first one, as far as man alone is concerned' (1984: 43). Jonas is not alone in using the idea of responsibility to connect ethics and ontology. Emmanuel Levinas (2006: 55), for instance, argues thus: 'the responsibility that owes nothing to my freedom is my responsibility for the freedom of others'. But 
Herein lies a first aspect of the universalistic orientation in Jonas's ethical theory, one that I think remains central to our own normative imagination: humans can be appealed to as moral agents. In this case, moreover, the appeal builds on rather than stands in opposition to how we experience our relationships with nature. This argument, contends Jonas, undermines the notion of progress as a central normative tenet of modern societies - not least the utopianism that is apparent in the idea of emancipation from nature (1984: 188-92); what we need instead is to 'unhook the demands of justice, charity, and reason from the bait of utopia' (1984: 201). ${ }^{11}$ For all its scepticism towards teleological conceptions of nature, modern science does depend on the most teleological of modern ideas: the accumulative betterment of social life through sustained technological improvements. Kicking contemporary challenges into the long grass under the expectation that, because science and technology will continue to thrive, the future will look after itself, is no longer an option. On the contrary, argues Jonas, taking responsibility for one's actions now in the present offers the only possible foundation for a sound ethical position.

The obligatory force of the imperative of responsibility is not derived from its claim to logical consistency, nor can it be seen in a Kantian way as the pure act of a self-legislating will. Rather, what makes the imperative of responsibility binding is its ontological claim; we are now confronted with the requirement that humans continue to exist. The greatest contribution of Kant's moral theory, Jonas continues, was the idea that moral commandments need to be rationally justified. But this has proved also its greatest shortcoming because reason has not proved rational enough to canvass people's support for actual changes in behaviour. Jonas suggests that we change track, and so his ethical command is now introduced as an ontological statement: the continuous existence of humanity is commanded on the basis that humanity already exists and this is a fact that requires no additional justification:

Levinas and Jonas's positions stand apart on two grounds: first, Levinas (2006: 7) describes this responsibility as traumatic and even anarchic, whereas we have seen that Jonas's formulation still resonates with Kant's proceduralism. Second, Levinas sees this responsibility as defined in a fundamentally anthropological manner as it focuses on the reciprocal relationships between human beings $(2006: 33,55,72-4)$. As we are about to see, Jonas's idea of responsibility is a command of nature that is built on the lack of reciprocity.

${ }^{11}$ Utopianism comes as a major theme critiqued in Jonas's work on the basis that utopian thinking depicts the future as an excuse to neglect the present. Jonas uses Ernst Bloch's principle of hope as paradigmatic of that position and contrasts it with his own principle of responsibility. It is worthy of note that although the German editions of both books speak of a Prinzip (of hope and of responsibility), in the English edition, whose translation Jonas supervised, the principle of responsibility is turned into an imperative. 
Groundless itself (for there could be no commandment to invent such creatures [as humans, DC] in the first place), brought about with all the opaque contingency of brute fact, the ontological imperative institutes on its own authority the primordial "cause in the world" to which a mankind once in existence, even if initially by blind chance, is henceforth committed. (1984: 100)

We are in the presence of two different but intimately related propositions: there is the first, empirical, claim that humanity actually exists and this requires no further proof. It is a fact which, in its very transparency, remains 'normally unexpressed' even if it is 'implicit in all further imperatives' (1984: 100). ${ }^{12}$ The second, ethical proposition, commands that humanity continues to exist according to the self-legislating powers that it currently enjoys. We have seen that Jonas is at pains to emphasise the fact that its binding character as an imperative does not derive from practical reason but is justified in ontological terms. Indeed, the ontological weight of Jonas's imperative does not undermine the equally fundamental fact that humans remain free and are able to turn away from their duties; they can say no to a reasonable request, change their mind and default on their promises. But Jonas is aware of this and he is not committed to the kind of moral ontology of the good for which we will criticise Charles Taylor's argument in Chapter 6: evil is an objective aspect of human existence. As the sources of ethical dissent can indeed be of various kinds, the key point for Jonas is that, as we search for legitimacy, the only authority that remains available for us lies in the ontological presence of humanity, which is ultimately a fact of nature (1984: 76-7). The fact that a human being 'can have responsibility means also that he must have it ... Here the mere capacity is the sufficient condition for the actuality' (1984: 99). Humans must care about the environment because they can do something about it. In so far as this commanding 'ought' is ontological, the imperative of responsibility does not belong to conventional ethics as a doctrine of rational motivations.

We now arrive at what I think is the most radical argument in the whole of Jonas's philosophy: our ability to base ethical commands on firm ground is to be based on nature rather than on principles. As an ethical idea, responsibility can work in a way that no previous moral theory has before because it is modelled on what in his view is the most basic fact of nature: 'the care of progeny, so spontaneous that it needs no invoking the moral law, is the primordial human case of the coincidence of objective responsibility and the subjective feeling of the same' (1984: 90, my italics). Responsibility offers a unique form of ethical command because it is not based on reciprocity and comes to us instead from what is unique and

${ }^{12}$ A similar ontological command to continuous existence underpins, it seems to me, Marx's early materialist position. See Chernilo (2013: 149-59). 
particular in a being who has been placed under our custody. Responsibility towards one's children is the archetype of responsibility as such, Jonas contends, because it 'is the only class of fully selfless behavior supplied by nature ... the archetype of all responsible action ... fortunately requires no deduction from a principle, because it is powerfully implanted in us by nature' (1984: 39, my italics). ${ }^{13}$

The gap between the is and the ought that is central to all moral theories, continues Jonas, has so far only been bridged by divine or human fiat: if the former, the solution depends on whether the source of divine authority is open to challenge on the grounds of its existence being contested; if the latter, the problem lies in the fact that human authority alone does not carry enough binding power. Only the ontology of the continuation of existence can solve this problem and create a new kind of ontological ought: 'when asked for a single instance (one is enough to break the ontological dogma) where that coincidence of "is" and "ought" occurs, we can point at the most familiar sight: the newborn, whose mere breathing uncontradictably addresses an ought to the world around, namely, to take care of him' (1984: 131). Jonas's ethical naturalism bases its obligatoriness on a responsibility that is grounded biologically in our feelings of duty and care towards others who cannot fend for themselves. It is the fact that duty and care become genuinely intertwined that allows Jonas to contend that the ethical commands that are thus derived are grounded in nature even if they cannot be justified rationally: the 'right of the object is prior to the duty of the subject ... all proofs of validity for moral prescriptions are ultimately reduced to obtaining evidence of an "ontological" ought' (1984: 130). It is this amalgamation of duty and care that, allegedly at least, allows Jonas to contend that he has overcome the motivational deficits of Kantianism; here, instead, there can be no gap between what I want and what I ought to do. Nature offers the ontological grounding for normative authority because it exists objectively, because purposive self-conservation is a value for life itself, because humans have the ability to take responsibility for nature and because human beings are part of nature.

In sum, Jonas's idea of responsibility matters to us because it emphasises two critical dimensions: First, responsibility is an idea that, as an anthropological capacity, precedes its social actualisation. Even if we want to eschew the contentious implications of its being grounded in us by nature, the substantive point that remains is that responsibility can and needs to be seen as a general anthropological feature that defines our

${ }^{13}$ Compare this with what we will discuss in Chapter 8. There, Luc Boltanski argues that the idea of a just action lies in the fact that it is to be based on reciprocity, whereas interpersonal relations that are based on power or love do not follow this pattern. 
humanity independent of society. Second, Jonas's idea of responsibility also allows us to reflect normatively on what is arguably one of the most important dimensions of social existence: social inequality. Human responsibility is conceptualised as that special kind of accountability that comes from the fact that we can do certain things: and we must because we can. Rather than reducing a sociological account of inequality to questions of power, Jonas creates a normative framework that helps us rethink the extent to which inequality leads to normative assessments and practical commitments.

\section{IV}

A connection can now be made between Jonas's arguments above and the principle of natality that we have seen is central to Arendt's conceptualisation of the human condition: both thinkers equally locate humanity's self-renewal at the centre of their normative insights. The open-ended condition of human life depends on the change and renovation that 'automatically' comes with every new generation. Indeed, as I mentioned briefly in Chapter 2, this interest in natality may have to be explored further vis-à-vis Heidegger's emphasis on death in Being and Time - it is a philosophy of those who had, quite literally, survived a destiny that called for their death and, in so doing, were able to forge a new life for themselves. But if in Arendt the principle of natality is fundamentally tied to ideas of creativity and originality, Jonas's organic conception of natality needs to restrict these in the present in order to make room for the humans of the future. This is an idea of natality that needs to respond to the, somewhat conservative, call of nature.

Jonas is critical of several aspects of Kantian ethics: the defeatism of its claim on the impossibility of a rational metaphysics, the excessive emphasis on logical consistence, the inability to account for the irrational outcomes of rational decisions and, last but not least, the fact that it cannot adequately motivate individuals to follow moral commands. But some of these charges seem exaggerated - or at least they apply also to Jonas himself: with regard to motivational deficits, for instance, Jonas's imperative cannot be said to be on much stronger grounds than Kantian morality. Nature's existence is in danger because of human action and the call of nature is yet to become truly audible. Crucially, the form of Jonas's imperative is procedural in a way that is indeed modelled on Kant's, and Jonas's substantive argument retains the need for individual human beings, and these now include future humans, to see themselves as a self-legislating body: our duty towards future generations is based on our duty to affording them the chance to become self-legislating beings. Similar to Kant's 
argument, this self-legislating dimension is both subjective - only individuals can decide for themselves - and objective - it shall provide sound reasons for action. Even if not based on a teleological idea of progress, Jonas's imperative of responsibility appeals as much to future consequences as several other ethical theories (see also Chapter 6). The rule of 'general inclusion' that lies at the centre of the imperative of responsibility is something we have also grown familiar with throughout the twentieth century. The underlying principle that no one can be forced to accept decisions that would go against their best interests is also paramount for Jürgen Habermas (1990a) and John Rawls's (1999a) ethical theories. This commonality is yet another expression of the fact that Jonas's moral theory is closer to Kantianism than he would like to admit. ${ }^{14}$

Under this logic of inclusivity, the key test of sound moral reasoning is precisely that we give voice to all those who may potentially be affected. The same counterfactual logic that applies to Rawls's veil of ignorance and to Habermas's discourse principle is here given a new specificity by making an explicit argument for its temporal dimension: the right of future generations to exist under conditions that are at least no worse than our own. In principle at least, Kant's original formulation of the categorical imperative of morality allows for moral reasoning to be pursued in private but this is not the case for Habermas, Rawls and Jonas: for all three, the inclusion of those who may be potentially affected requires an act of political engagement of a whole range of perspectives that makes public discussion necessary. Collective deliberation plays a central role in modern democracies; therefore, the organisation of public discourse and political life more generally are of key importance. ${ }^{15}$ This clause is arguably more onerous in Habermas's formulation because for him that public disposition is by definition open-ended, while for Rawls it is essential that the fictional acceptability of the original position is limited to those who are to live within those institutions that are now being designed - for instance, a modern nationstate. To Jonas, the 'public' whose assent we must seek is axiomatically

${ }^{14}$ According to Kant, no moral theory can work without an explicit consideration of the opportunities we afford to future generations: 'it is a crime against human nature' to prevent future generations from making their own decisions about substantive issues through their public use of reason (1999: 57). Assessed against that standard, it seems to me that Habermas does not have a consistent argument about the future, whereas Rawls's (1995) emphasis on the stability of social orders looks openly eschewed against a meaningful inclusion of the future in the original position. See Loewe (2015) for further discussion on the limitations of Rawls's temporal argument. See also Chapter 6 for Charles Taylor's argument on the commonalities between naturalism and modern proceduralism.

15 I have discussed some further implications of the public aspect of moral and political deliberations in relation to Habermas in Chernilo (2013b). See also the discussion in Chapter 5. 
indeterminate and, given the scale of technological change and its impact over the environment, it may potentially include future humanity as a whole (1996: 99-112).

We should not, however, overstate the extent to which Kant would have been contented with purely private deliberation. For instance, Arendt (1992: 20,40) made the point that public deliberation is in fact central for Kant on the grounds that his idea of freedom presupposes human plurality; otherwise, we may contend, there would be no need at all for the strictly deliberative dimension of the categorical imperative. In fact, it is Jonas who seems to be walking on thinner ice here. If we put their differences to one side, public and ultimately democratic debate is ultimately an expression of the rationality of our decisions for Kant, Rawls and Habermas. Jonas, however, vocally sides with technocracy and central planning when it comes to the task of making collectively binding decisions over the future. Jonas is very sceptical of liberal democracies being able to afford the level of self-restraint that would be required to secure continuous human existence on the planet - on this he has perhaps been proved right. And while empirical support may be found for this scepticism, Jonas was positively though with hindsight also wrongly - impressed by the success of central planning in former socialist countries as a way of making a more efficient use of scarce resources. Jonas is committed to a mild form of public debate that does not lead to democratic deliberation as the best form of achieving rational decisions: opposed as he was to openly authoritarian regimes, he favoured what we may describe as a benevolent technocracy of those who, although they may not know so much better than the rest of us, may at least have the incentives to coordinate the use of resources more rationally. His argument is that a technocratic way out of the contemporary ecological crisis may have to be accepted as a lesser evil because the short-termism of capitalism and the partisan politics of Western democracy do not offer incentives to take the future as seriously as it is required (1984: 147-51). Somewhat paradoxically, his proposal becomes that of a technocratic way out of the crises of modern technology: technocratic domination (in politics) may prove the best way to achieve technocratic liberation (in science).

We have said that at least part of Jonas's motivation to revise Kant's categorical imperative was that he considered it too demanding, but if now his argument depends on technocratic decisions having to pre-empt democratic mistakes, it is not at all clear that his own appeal to nature is as strong as we would require it to be. Indeed, things do not get any easier for him when he spells out the implications of his position for such difficult cases as suicide:

No consent to their nonexistence or dehumanization is obtainable from the humanity of the future, nor can it be assumed; and were it nevertheless imputed 
to them (an almost insane imputation), it would have to be rejected. For there is ... an unconditional duty for mankind to exist, and it must not be confounded with the conditional duty of each and every man to exist. The right of the individual to commit suicide is morally arguable and must at least for particular circumstances be conceded: under no circumstances has mankind that right. $(1984: 37 \text {, underlining mine })^{16}$

However dramatic, personal suicide remains an option that cannot be condemned morally. Collective self-annihilation poses a different dilemma, however, because it is the continuation of the human enterprise as such that comes under threat. Jonas's insistence that collective existence is an unconditional duty should not be confounded with the conditionality of individual existence - or indeed the unconditionality of the existence of this or that human collectivity: the principle of responsibility is not committed 'to the future of human individuals but to the idea of Man' (1984: 43). But the possible slippage from the duty for humanity to exist to the right of a person to commit suicide is anything but straightforward.

These illiberal tendencies in Jonas's thinking are sometimes hard to make sense of - indeed, they are difficult to reconcile vis-à-vis his personal account of the impact of the loss of civil freedoms for Jews in Nazi Germany (which was the main reason for his emigration to Palestine before the war). At the same time, these comments may have something to do with the ontological status of the self-preservation of human life: the continuation of life itself was arguably the only hope that remained available to concentration camp inmates or those who were forced to live under increasingly inhumane conditions. But even at a strictly conceptual level, a major problem remains: if the 'sacrifice' of future humans is morally unacceptable, how are we to determine what constitutes 'tolerable' sacrifice among our own contemporaries? Even if the rich of today would freely decide to restrain themselves in order to grant future generations true self-legislative opportunities, the question remains open about the responsibility of those who cannot lead a human life now in the present and for whom that very possibility may depend on, say, the destruction of the natural resources that may then restrict the resources or opportunities to be afforded to future generations: what is the threshold that may make the current restriction to our self-legislative powers acceptable in order to allow these opportunities to future human beings? At one level, the universalistic orientation in Jonas's thinking points to a cosmopolitan vision of human solidarity that allows only for the whole of humanity - both present and

16 There is in fact an anthropological specificity in this freedom to choose suicide as a course of action: 'Suicide, this unique privilege of man, shows the ultimate manner in which man can become the object himself' (2001: 187, my italics). 
future. But without social and political cleavages, this universalism unduly flattens the very differences that are to remain central for thinking normatively about these issues. ${ }^{17}$ However unwittingly, Jonas's anti-utopian vision of the future ends up eroding all legitimacy regarding the present: it is an inverted teleology that, for all its criticism of progress, it nonetheless favours the future over the present. Furthermore, if the self-legislating aspect of human life is the highest value that is worth protecting in what constitutes a human life worthy of its name, then we should not be so harsh in our indictments of democratic decision making.

Our being alive as human beings is a mundane though somewhat implicit fact for both sociology and philosophy - but these disciplines are not directly concerned with the fact that humans are alive but that they live well (1984: 99-100). That is, sociological knowledge depends on the fact that we are alive in exactly the same way as all other species who adapt themselves organically to their physical environment. But we are also alive in a completely unique way vis-à-vis all other species: we are conscious of ourselves, can imagine different ways of leading our lives and can take responsibility for our actions. Both conditions are equally inscribed in human nature and, if Jonas's naturalism is to have any purchase at all, it can only do so by taking the specificities of human nature into account. Human reason offers a claim to knowledge that knows no boundaries, but we should not hypostatise this for a principle of general authorship. Modern social science, on the other hand, seems to have inverted this principle as it suggests that we can only adequately understand those regions of the world that we ourselves have construed. For sociology, and the social sciences more broadly, this means that the perennial tension between facts and values, between description and normativity, is itself ontologically grounded because the normative itself depends on ideas of human nature. As we describe the social world, those very descriptions that speak about social institutions cannot help being assessed in normative terms; that is, whether they favour or undermine the development of those properties on which human life thrives.

${ }^{17}$ See Chernilo (2012a, 2012b) for an idea of cosmopolitanism that rejects this flat conception of humanity. 
Of all the writers we are looking at in this book, Jürgen Habermas is the only one who arguably belongs, equally comfortably, in philosophy and sociology. Habermas may be said to represent the most genuine effort to develop the kind of philosophical sociology in which I am interested: the relevance of keeping both traditions together because of their potential to offer a claim to knowledge that is not only empirically sound and theoretically consistent but also normatively relevant. ${ }^{1}$

Indeed, the question of the relationships of philosophical and scientific knowledge-claims is one of those themes that has accompanied Habermas throughout his intellectual career. This was one of the original motifs behind Habermas's (1974) early work Theory and Practice, which focused on the implications of the transition from a 'classical' (i.e. philosophical) to a 'modern' (i.e. scientific) conception of politics. A change that is conventionally marked by the publication of Thomas Hobbes's Leviathan in the middle of the seventeenth century, Habermas reconstructs this change as a move away from a traditional idea of politics based on prudence and virtue to a modern one based on lawlike or instrumental knowledge about human nature and society. The task of a critical theory of society was then to rethink the relationships between science and politics by finding a new standpoint that is neither restorative nor merely technocratic (2003a: 277-92). Habermas's (1972) first systematic project for the renewal of critical theory, as outlined in Knowledge and Human Interest, focuses explicitly on the possibility of getting the best of both traditions: the empirical/ theoretical knowledge claims that we associate with the modern sciences

\footnotetext{
${ }^{1}$ It is in this spirit that I have published on various aspects of Jürgen Habermas's work: nationalism and the postnational constellation, cosmopolitanism and the EU, his theory of generalised symbolic media, and the philosophical foundations of his critical theory - in particular with regard to modern natural law (Chernilo 2002, 2007a, 2007b, 2013b). As this chapter looks at the question of language and, in particular, to his idea of a communicative competence, my argument here focuses for the first time on the 'core' of Habermas's contribution to contemporary social theory. On the sociological and philosophical foundations of Habermas's project, see McCarthy (1985) and Schnädelbach (1991).
} 
and the reflective/normative stance that we associate with modern philosophy after Kant. Fast-forward two decades, and a similar sensibility still runs through Habermas's (1992a) writing on the postmetaphysical constellation: as science continues to develop and, through technological innovations, continuously transforms the world we live in, we must consider the roles, if any, that remain open to philosophy - not least in terms of raising the kind of existential questions that trouble human beings as human beings. Even his more recent work on naturalism and religion bear the mark of the constant attempt to bring together their different claims to knowledge (2008).

There is a second sense in which Habermas's work is fundamentally informative for my project of a philosophical sociology. Over the past five decades or so, as most mainstream social and political thought has grown increasingly sceptical of universalistic arguments, Habermas is still committed to universalism as an intellectual orientation. In the wake of the humanism debate that we reconstructed in Chapter 1, Habermas has remained unimpressed by the influence of Heideggerian tropes in writers such as Derrida, Foucault and Gadamer. Rightly in my view, Habermas takes issue with two of the propositions that have since become mainstream in the social sciences. On the one hand, there is the irrationalism that can be easily derived from ideas of deconstruction or archaeology. As they emphasise the contingency, exclusions and power differentials that underpin modern claims to knowledge, Habermas queries Derrida and Foucault for having dramatically undermined the very possibility of making normative claims. Ideas such as responsibility and autonomy, let alone fairness and democracy, can hardly be maintained if we are serious about the deep sources of modern irrationalism. Through his polemical style, Habermas did not always appreciate the extent to which Foucault and Derrida themselves tried to avoid these pitfalls and sought to rekindle some kind of rational core within their works; not least with regard to the progressive side of their politics. ${ }^{2}$ But Habermas does have a point when he highlights their performative contradiction: they seek to reclaim the normative implications of their arguments by appealing to the very kind of normative/communicative rationality whose validity they have just negated. ${ }^{3}$ As their ideas have 'trickled down' and become mainstream in

${ }^{2}$ I touched on Habermas's early critique of Heidegger in Chapter 1, but see (1990b: 131-60) for his 'mature' assessment. A more cautious account about the relationships between Heidegger's philosophy and his politics can be found (Habermas 1992b). Habermas's critique of Foucault and Derrida is available (Habermas 1990b: 161-84 237-66), but see also Habermas's more engaging attitude towards Derrida's politics (Borradori 2003).

${ }^{3}$ See Matustik (1989) on Habermas's idea of performative contradiction. 
the humanities and social sciences of the past fifty years, we are above all left with the key irrationalist implication that knowledge is power: indeed, that it is only power. On the other hand, Habermas criticises the relativism that in his view is built into Gadamer's hermeneutical project (1988). Habermas is here troubled by both the epistemological and normative implications of the historicist claim that, because linguistic and cultural traditions are seen as self-contained, they cannot genuinely communicate and understand each other: epistemologically, he rejects the idea that there is such a thing as a close tradition and defends the notion that all human languages can be reconstructed through a formal or universal pragmatics; normatively, this is deeply problematic as reminiscent, for instance, of conservative ideas of authenticity or indeed ethnic conceptions of the nation. We can in fact read Habermas's critique of Gadamer as a wider critique of the excesses of social constructionism; that is, as a rejection of the point of view that the world exists only to the extent it exists for us within our own particular linguistic universe. Habermas's resolute rejection of all these positions - irrationalism, constructionism and conservative notions of authenticity - is also central to my project of a philosophical sociology. ${ }^{4}$

There is, finally, a third tenet of my project of a philosophical sociology where Habermas's arguments do not seem to fit quite so well - at least not at first sight. It is a key contention of this book that we still need a fuller articulation of the main anthropological dimensions that can sustain a universalistic principle of humanity in the social sciences. In order to do this, I have argued that we ought to be able to isolate, as it were, the irreducibly human core that transpires from our various understandings of social life. Through the importance he has given to ideas of linguistic understanding and communicative action - and indeed by his commitment to the so-called linguistic turn - Habermas does not appear to be particularly interested in the delimitation of those uniquely anthropological capacities that makes us human. ${ }^{5}$ Closer to the mark, it seems to me, is the view that Habermas's theory of communicative action still needs to confront explicitly the way in which its own emphasis on social action does depend on implicit ideas of human nature (Joas 1991). An argument that applies also to most of the other writers I am surveying in this book, the anthropological question is not central to Habermas's concern. But in this case it is the very idea of a linguistic turn, which in Habermas's version

${ }^{4}$ See Kelly (1988), Mendelson (1979) and Misgeld (1977) for the context and implications of the debate between Gadamer and Habermas.

5 The standard position in the literature remains that Habermas explicitly eschews all notions of human nature (e.g. Moon 1995: 143), while his emphasis on linguistic communication has led to the criticism that he neglects the bodily dimension of our shared humanity (Schlossberger 2014). See also Alvear (forthcoming) and Papastephanou (1997). 
is construed as a rejection of the so-called paradigm of consciousness, seems to speak in favour of what Margaret Archer has referred to as sociological imperialism: an idea of the human that is seen as society's gift. ${ }^{6}$

The original idea of the linguistic turn can be traced back to the reception of Kant's first critique on pure reason. There, Johan Hamman criticised Kant for not having paid significant attention to the very medium that makes thinking at all possible: reason and language cannot be looked at as two different things (Lafont 1999). By the time Habermas used the term in the early 1970s, he was already building on the insight that the medium of language was anything but neutral with regard to thinking but, equally importantly, to action itself. The centrality of the relationships between action and speech - as expressed in J. L. Austin's motto of 'Doing things in saying something' (1976: 156) - is based on Habermas's adoption of speech act theory as developed in Anglo-Saxon analytic philosophy. Habermas's version of the linguistic turn then combines insights that come from both analytic philosophy and the 'German' hermeneutical tradition (2003a: 51-81). But such umbrella notions as the 'linguistic turn' arguably hide as much as they illuminate, and in Habermas's case there are several different claims being pursued at the same time:

1. the claim that intersubjectivity is to be preferred over consciousness as a starting point for a general anthropology;

2. the claim that communication is the best starting point for a general social theory;

3. the claim that the interiority of consciousness cannot be accessed but through language (and even then only imperfectly);

4. the claim that discursive performance works better than intentionality for symbolic meanings to be studied empirically;

5. the claim that a consensual theory of truth is to be preferred over representational or ontological theories of truth;

6. the claim that an adequate concept of human communication must include both its cognitive and its communicative use;

7. the claim that Kant's transcendental presuppositions are to be redefined as counterfactual idealisations of language itself;

8. the claim that, because it looks at the way in which actions become coordinated, the idea of communicative action is more general than that of strategic action;

${ }^{6}$ Archer's critique centres precisely on those arguments that concede too much to the linguistic dimensions of our humanity. Archer uses Richard Rorty as a paradigmatic case but the criticism applies to all those who have embraced the linguistic turn. See Archer (2000) and Chapter 7. 
9. the claim of the relative normative primacy of the public over the private;

10. the claim that human language's immanent orientation to understanding works also as a general normative goal in democratic decision making.

Similar to our reconstruction in other chapters, the task here is also to trace back Habermas's 'anthropological argument' and reassess it in relation to his own understanding of human language and communication. For this purpose, the key texts we will look at were originally published in the 1970s, which may be seen as the transitional decade in which his ideas of communicative action and communicative rationality took shape. More precisely, we are interested in a period that began with the first delimitation of the idea of communicative action - his 1968 article Science and Technology as Ideology - and culminates in 1981 with the publication of the two volumes of Theory of Communicative Action (Habermas 1971, 1984a, 1987). We will be paying close attention to how these arguments were introduced in his Christian Gauss lectures at Princeton University in 1971 (2001) and also in his piece 'What is universal pragmatics?' of 1976 (1979). Taken together, they offer Habermas's most systematic account of the philosophical foundations of his theory of language. But what also transpires from these texts, and this is an argument that Habermas has not explicitly pursued afterwards, is that the study of language and communicative action is to be construed around the idea of a universal 'communicative' or 'interactive' competence that does define us as members of the human species.

\section{I}

As we discussed in Chapters 3 and 4, philosophy and the social sciences in the 1970s were fundamentally influenced by cybernetics as a general scientific model with which to study all forms of communication. In Norbert Wiener's (1954) original formulation, this new science of communication turned conventional wisdom upside down: instead of highlighting our species's uniqueness on the grounds of its linguistic prowess, human communication was a special case that needed to be studied as part of a general science of communication that applied to other forms of life as well as to increasingly 'intelligent' machines. Inside sociology, this insight was fully taken up by Parsons and Luhmann's interest in communicative and symbolic processes (see Chapter 3). Habermas's famous discussion with Luhmann in 1971 (Habermas and Luhmann 1971), as much as his adoption of the linguistic turn itself, can then be seen as his own reception of the cybernetic predicament: on the 
one hand, he accepts the importance of communication as a core concept for philosophy and the social sciences but, on the other hand, he rejects the idea that the specificity of human communication is derivative vis-àvis more general, non-human, forms of communication. On the contrary, his argument is that our understanding of language and communication must proceed from the standpoint that their human features are precisely the ones to which we must pay special attention because they are a form of action. We may even see this as a particular rendition of the question of anthropocentrism that has accompanied us throughout: whether human language is to be seen as the model for other forms of communication or, conversely, whether we will only be able to fully understand human language as we radically decentre it and focus on our understanding of communication as such. ${ }^{7}$

Habermas opens his 1971 lecture series with the proposition that meaning is to be taken as sociology's central category (2001: 3). Not altogether different from Weber's idea that social action is always oriented towards the symbolic meanings that others may attach to it, Habermas now contends that intentional meanings are never fully dissociated from linguistic ones (1984a: 102-8, 116). But it is only through language that we get empirical access to meaning: even if we still do not fully understand how this connection between language, meaning and intentions ultimately works, the fact remains that, methodologically speaking, intentions and motivations are never decoupled from the contents of linguistic utterances. The argument is not only methodological, however, because the role of the notion of meaning is itself dual: at one level, meaning refers to the semantic content of linguistic symbols; that is, it requires understanding the substantive issues that are associated with a particular symbolic content. But there is an underlying level to which more attention now needs to be devoted: meaning refers also to the explanation of the rules according to which an expression has been made and thanks to which it becomes meaningful (1979: 11-12). The delimitation of this new approach to the study of language Habermas connects it to Noam Chomsky's idea of a generative grammar and John Austin and John Searle's speech act theory: rather than concentrating only on 'the content of a symbolic expression or what specific authors meant by it in specific situations', what Chomsky in particular made clear is the need for paying systematic attention to 'the intuitive rule consciousness that a

${ }^{7}$ Habermas traces back the anti-anthropocentric understanding of language that cybernetics advances to Charles Morris's work on semiotics in the late 1930s. Morris's behaviouralism also justifies his argument that the study of communication in general allowed us to understand human language as a fact of nature (1979: 6-7). On the contributions that cybernetics make to current posthumanism, see Hayles (1999). 
competent speaker has of its own language' (1979: 12, my italics). ${ }^{8}$ Habermas then contends that, to the extent that meaning is now to play such a key methodological role in the social sciences, we have also raised the conceptual bar: we face the fundamental 'metatheoretical decision as to whether linguistic communication is to be regarded as a constitutive feature of the object domain of the social sciences' (2001: 4, my italics). ${ }^{9}$

Habermas then adopts what he calls an 'essentialist' (he will later on use 'realist', 2003a: 1-49) approach that commits to an ontological definition of its object of study. This essentialist strategy is put to work through the notion of 'rational reconstructions'. As a methodological strategy, rational reconstructions are meant to challenge the ways in which contemporary science deals with the problem of the constitution of its object of study, on the one hand, and the relationships between expert and lay knowledge, on the other: 'reconstructive procedures are not characteristic of sciences that develop nomological hypotheses about domains of observable events; rather, these procedures are characteristic of sciences that systematically reconstruct the intuitive knowledge of competent subjects' (1979: 9). In a stronger formulation of this argument, Habermas then contends that for rational reconstructions to prove adequate, 'they have to correspond precisely to the rules that are operatively effective in the object domain - that is, to the rules that actually determine the production of surface structures' (1979: 16, my italics). ${ }^{10}$

This is an approach that, in various forms, Habermas has continued to uphold ever since. By the mid 1980s, for instance, it remained the guiding intuition behind his reassessment of developmental psychology. Through an engagement with Lawrence Kohlberg's theory of moral development, Habermas then sought to account for the processes that explain the rise and main features of an individual's moral consciousness; that is, to 'rationally reconstruct the pretheoretical knowledge of competently judging subjects' (1990a: 118). Starting with a discussion of G. H. Mead's notion of ideal role taking, the argument is that the development of the capacity for moral judgement is to be seen as invariant, irreversible and consecutive so that a 'hierarchy' is being formed in which 'structures of a higher stage dialectically sublate those of the lower one' (1990a: 127). But the key to Habermas's argument, and here he departs from both Kohlberg and Piaget, is that we can only fully understand the way in which adults engage in moral reasoning if we are prepared to treat them

${ }^{8}$ See also Habermas (1991b).

${ }^{9}$ Indeed, with a different terminology this is also a key argument in Theory of Communicative Action: because linguistic meaning refers to justification and validity, which in turn raise questions of justice, autonomy and responsibility, the definition of an idea of rationality imposes itself from within to any theory of society (1984a: 1-7, 136).

${ }^{10}$ See Pedersen (2008) for further discussion of the idea of rational reconstructions. 
both as participants in psychological experiments - thus reproducing the subject-object logic of the natural sciences - and as participants in reciprocal forms of interactions in which subjects encounter one another as euqals. The possibility of establishing the adequacy of our explanations of moral reasoning depends also on how expert statements resonate with the lay knowledge of people themselves: '[p]rincipled moral judgments are not possible without the first step in the reconstruction of underlying moral intuitions. Thus principled moral judgements already represent moral-theoretical judgments in nuce' (1990a: 175).

As he elaborates this further in Theory of Communicative Action, Habermas accepts that the perspectives of participants and observers are to remain different and cannot be conflated (1984a: 113-17): while participants orient their actions towards specific goals, the observer must suspend all pragmatic aims other than understanding other people's actions. But this cannot be turned into the arguments that observers have a superior understanding of lay actions. Habermas contends that the kind of 'virtual participation' that define social scientists in their expert roles does not fully liberate us from the need to understand reasons as reasons; rather the opposite, 'on this point, which is decisive for the objectivity of understanding, the same kind of interpretive accomplishment is required of both the social-scientific observer and the layman' (1984a: 116). In other words, for the social scientific observer to genuinely understand an action or linguistic utterance, she cannot but have recourse to the same lifeworld traditions as participants themselves. Thus seen, the scientific observer:

must already belong in a certain way to the lifeworld whose elements he wishes to describe. In order to describe them, he must understand them; in order to understand them, he must be able in principle to participate in their production; and this participation presupposes that one belongs ... this circumstance prohibits the interpreter from separating questions of meaning and questions of validity in such a way as to secure for the understanding of meaning a purely descriptive character. (1984a: 108, my italics)

The key point here is that the very idea of validity requires observers to be able to grasp the reasons that are being offered in support or rejection of a particular situation. But this perspective is only methodologically available in their role as participants: 'reasons are of such a nature that they cannot be described in the attitude of a third person, that is, without reactions of affirmation or negation or abstention. The interpreter would have understood what a "reason" is if he did not reconstruct it with its claim to provide grounds; that is, if he did not give it a rational interpretation in Max Weber's sense' (1984a: 115-16). 
It is thus worthy of mention that Habermas concedes that his project is based on a 'naturalistic ring' that highlights those general properties or abilities that define the species as a whole; what we are genuinely talking about here is the 'ontogenesis' of a very unique human 'capacity for speech and action' (1990a: 130). ${ }^{11}$ But arguably more salient is one normative implication that becomes immediately apparent: there's an egalitarianism of perspectives that necessarily underpins the study of human linguistic interactions: as competent speakers of particular linguistic communities, scientists and philosophers do not have a position of privilege vis-à-vis lay actors. An argument to which we will return below, we can see that symmetry and reciprocity are central to Habermas's normative preference for an ideal speech situation: 'the counterfactual conditions of the ideal speech situation can also be conceived of as necessary conditions of an emancipated form of life' (2001: 99). On the one hand, this egalitarianism accounts for the fact that human communication has an immanent connection not only to an idea of truth but also to notions of freedom, autonomy and responsibility - all of which refer to the accountability of one's actions (2001: 99-101). On the other hand, this egalitarianism has also wider implications vis-à-vis the emancipatory tasks of critical theory in general, and democratic decision making in particular: ' $[\mathrm{t}] \mathrm{he}$ formal anticipation of idealized conversation (perhaps as a form of life to be realized in the future?) guarantees the "ultimate" underlying counterfactual mutual agreement, which does not first have to be created, but which must connect potential speaker-hearers a priori' (2001: 102). ${ }^{12}$ The intrinsic normative dimension of social life depends on the fact that our linguistic interactions are oriented towards understanding and that the idea of 'reaching a mutual understanding is a normative concept'. Habermas then concludes that ' $[\mathrm{o}] \mathrm{n}$ this inevitable fiction rests the humanity of social intercourse among people who are still human, that is, who have not yet become completely alienated from themselves in their self-objectifications' (2001: 102, my italics).

This notion of idealisation plays a major role in Habermas's argument: there is not only an ideal speech situation but also an ideal speakerlistener-actor whose own 'ideal rule-competence' becomes the anthropological feature that makes human communication possible. This again

${ }^{11}$ As we discussed in Chapter 4, naturalism is of course a problematic term and, through his interest in communicative action and symbolic processes, Habermas's position is arguably best depicted as anti-naturalist (Hayim 1992). Habermas's more recent position against a reductionist form of naturalism is best articulated in his essays on eugenics (2003b). See also Taylor's critique of naturalism in Chapter 6.

12 Ingram (1993) gives a thorough account of the democratic implications and difficulties faced by Habermas's discourse on ethics theory. 
builds on Chomsky's idea of an 'innate linguistic capacity' that is available to 'all normally socialized members of a speech community': to the extent that they 'have learned to speak at all', they must have a 'complete mastery of the system of abstract rules' (2001: 71). While the actual performance of this competence can be more or less accomplished, as a general competence it is universally available and 'cannot be distributed differentially' (2001: 71): differently put, this communicative competence is general and universal but its performance is empirically differentiated and allows for degrees of skilfulness. Habermas speaks of the need to uphold a weak transcendentalism which, rather than thinking about the a priori conditions of all possible experiences (as in Kant's traditional version of this argument), takes a fallibilist approach whereby its claim to generality is sustained equally seriously though always provisionally: '[a]s long as the assertion of its necessity and universality has not been refuted, we term transcendental the conceptual structure recurring in all coherent experiences ... the claim that that structure can be demonstrated a priori is dropped' (1979: 21-2). Habermas then transforms 'Kant's "ideas" of pure reason into "idealising" presuppositions of communicative action', whereby the idea of reason is transformed from 'the highest court of appeal' into 'rational discourse as the unavoidable forum of possible justification' (2003a: 85, 87). This de-transcendentalisation aims to leave the problems of Kant's philosophy behind, and Habermas claims that this is central to the paradigmatic shift that the linguistic turn effectuates: ' $[\mathrm{t}]$ he rigid "ideal" that was elevated to an otherworldly realm is set aflow in thisworldly operations; it is transposed from a transcendent state into a process of "immanent transcendence." (2003a: 92-3). ${ }^{13}$

A line of critique that we first encountered in the Introduction when we discussed Ralf Dahrendorf's idea of homo sociologicus, Habermas also contends that role theories in sociology bring some of these issues into view: yet as they pay excessive attention to passivity and conformity, role theories are ultimately underpinned by an oversocialised conception of the human in which personality structures are deemed to merely reflect institutionalised values. While he does not use the language of human nature, Habermas's claim is effectively that sociological theories of role have an insufficient understanding of the underlying human attributes that make role acquisition at all possible. These theories concentrate only on their application to specific contents and cultural traditions and do not theorise the very competence that allows for roles to be developed: as they tend to work as a middle-range approach, they lack philosophical depth

${ }^{13}$ See Chernilo (2013a: 34-8, 203-21) for further discussion of this idea of immanent transcendence. 
(1984a: 76-82). It is however the idea of the general capabilities of the human agent that is at stake here, so the challenge is to make clear the possible correspondence between psychological or personality traits and social structures: 'I am convinced that the ontogenesis of speaker and world perspectives that leads to a decentered understanding of the world can be explained only in connection with the development of the corresponding structures of interaction' (1990a: 138, underlining mine). ${ }^{14}$

The full implications of these arguments will be unpacked below, but we can already highlight three of them: First, because the conditions of possible linguistic communication are not derived a priori (as in Kant), they themselves must be susceptible of empirical study. This justifies the need for the rational reconstruction of those general attributes that make human communication possible. Second, because human experiences do not refer only to events in the natural world that can be reconstructed vis-à-vis causal laws, we need also to conceptualise how interactive and communicative events are apprehended through interpretations. ${ }^{15}$ Third, because we are speaking of human communication, we must be able to reconstruct the general set of anthropological capabilities that make communication possible both in terms of properties that develop within the lifecycle of any individual member of the species (ontogenesis) and as properties that mark the evolution of the species as a whole (phylogenesis).

\section{II}

Human language and interaction are of course 'external' events in the world, but we only have access to them through the 'internal' medium that is linguistic communication. For us to be able to account for this peculiarly internal and external condition of language, we first have to be able to grasp the human competences that make it possible. This, Habermas contends, is to be achieved by unpacking the underlying system of rules - historical and invariable - within which these processes take place (2001: 11). Because of this duality of external and internal tasks, moreover, the meaning of linguistic utterances needs ultimately to refer back to the particular subject who had offered the emission (even if she may not be aware of the rules that made it possible). It is in this context that Habermas will openly argue that a monological model - that is, a conception of language that starts from an isolated individual - is fundamentally inadequate because the idea of symbolic meanings points to something that is

${ }^{14}$ See McCarthy (1979: xix) and Taylor (1991a: 29) for further discussion.

${ }^{15}$ According to Habermas, Charles Pierce made this argument with regard to instrumental action, while Wilhelm Dilthey made it in relation to communicative action (1979:22-5). 
already trans- or inter-individual. In terms of the philosophical tradition, Habermas rejects those approaches that, most famously in Kant, Husserl and Simmel, take the isolated individual as their initial building block and then look at meanings as a reflection of the internal states of an autonomous consciousness. Equally forcefully, he rejects the idea of human communication that is offered in so-called 'externalist' models, as espoused by system theory and structuralism: while they do not make meaning dependent on allegedly autonomous states of consciousness, these approaches fail because they cannot be traced back to the subjects' own selfunderstanding: neither individualists nor collectivists are able to give 'an accurate account of how intersubjectively binding meaning structures are generated' (2001: 16-17).

One main idea for this chapter has now revealed itself: the version of the linguistic turn that Habermas has adopted is one that, contrary to its more radical versions, cannot do away with a general anthropology. It requires him instead to redefine the terms within which it is to remain feasible. The challenge then becomes that of reconstructing the intrinsic capabilities that underpin the use of all human languages: '[i]n principle, anyone who masters a natural language can, by virtue of communicative competence, understand an infinite number of expressions, if they are at all meaningful, and make them intelligible to others' (2001: 7, my italics). We need to be able to construe a general procedure that can explain how are these skills possible at all; in other words, 'a theory of ordinarylanguage communication that did not merely guide and discipline the natural faculty of communicative competence, as hermeneutics does, but could also explain it' (2001: 8, my italics). It is this idea of a communicative competence that we now have to reconstruct in detail.

An argument that we have encountered before, the first property of the idea of a communicative competence is that its very conception 'must be derivable from the self-understanding of the very subjects who produce these structures'; we need to reconstruct 'the implicit know-how of competent subjects capable of judgement. What is to be explicated by these reconstructions are the operationally effective rules themselves' (2001: 10, my italics). A human subject is able to acquire and then perform roles efficiently because she is a person who is capable of knowledge, language and action. This, it seems to me, is key to Habermas's project of studying the human: the reconstruction of the possibility of congruence in the differentiated developments between cognitive, linguistic and interactive skills. These competences are of course interconnected but they develop independently from one another because we engage differently with external nature, language and society as the main objectual domains which, as they define human life, are to be seen as quasi-transcendental (1984b: 188-92). 
Habermas published in 1974 a piece where he offers a relatively short though systematic attempt to further delineate this quest. Possibly in order to emphasise the pragmatic side of his argument, Habermas speaks there of an interactive rather than of a communicative competence: at stake here are not only our linguistic skills but our more general abilities to interact competently with each other and the world. Although it is a piece that Habermas partly disowned afterwards (1979: 210), what matters to us here is how it explicitly defines the terms of the enquiry as the need for a general anthropology that looks at those competences that constitute us as members of the species: " $[\mathrm{t}]$ he use of the expression "interactive competence" points to the fundamental presupposition that we can investigate a subject's capacities for social action from the point of view of a universal competence that is independent from any particular culture and in a way that is similar to their normal capacities for speech and knowledge' (1984b: 187). ${ }^{16}$

Conventionally, discussions on Habermas's universal pragmatics have centred on two sets of issues (McCarthy 1985: 272-91). First, there is the question of the methodological status of rational reconstructions as the procedure that is to give us access to these general capacities. Here, one line of criticisms mirrors those that have been made against Chomsky's notion of a general competence and also against Piaget's idea of necessary evolutionary stages; namely, whether the idea of such a general competence can be credited at all. Secondly, Habermas builds on the distinction between know how and know that; that is, the difference between being successful in applying a rule and the ability to logically reconstruct and explain the rule itself (2001: 67-8). Usual examples here include the relations with those technological devices that we are able to manipulate efficiently regardless of how little we know how or why they behave in the way that they do. When it comes to language and interactions - and their basic units of analysis, sentences and utterances - Habermas's argument does seem straightforward: our ability to speak our mother tongue as much as the ability to efficiently interact in everyday social contexts are indeed independent from our ability to reconstruct the underlying grammar and sociocultural traditions that make these interventions appropriate. ${ }^{17}$ Genuine skilfulness requires a level of improvisation and 'feel for the game' that resists formalisation: F1 car mechanics and designers are not the fastest drivers of the

${ }^{16}$ This text is translated only in in part in Habermas (1976) and the sections that did not make the English version are precisely those in which he makes the stronger anthropological claims. In working through the unabridged version, I have also consulted the Spanish translation (1989).

17 Differently put, Habermas's idea of a generic competence can be seen as a refutation of the Turing test: the fact that we are able to work out how certain rules work and then apply them successfully still does not fully account for our position as competent users. 
cars they build; the mastery of the sociology of a particular set of social conventions does not secure that one's actions will be received as expected.

But here I would like to concentrate on a different dimension of Habermas's idea of a communicative or interactive competence. The notion of a universal pragmatics is itself ambivalently defined as being concerned with two, rather different, objects of study: universal pragmatics is meant to look into: (a) speech acts as the minimal units of language as they take place in contexts of interaction; and (b) a communicative or interactive competence as the general ability to generate and then follow the rules that account for successful linguistic interactions. My argument is that there is a constant tension in Habermas's argument so that he focuses, rather inconsistently, on both: the delineation of that general human capacity that is the communicative competence and the linguistic events in the world that represent the successful manifestation of this capacity. In one of the first definitions of universal pragmatics, in 1971, Habermas explicitly mentions both dimensions:

A theory of communicative competence must explain what speakers or hearers accomplish by means of pragmatic universals when they use sentences (or non verbal expressions) in utterances ... Universal pragmatics aims at the reconstruction of the rule system that a competent speaker must know if she is to be able to fulfil this postulate of the simultaneity of communication and metacommunication. I should like to reserve the term communicative competence for this qualification. (2001: 73-4, underlining mine) ${ }^{18}$

In his 1976 text on universal pragmatics, the general orientation of his project has not changed dramatically but the emphasis is now on the 'intuitive evaluations' that will allow for the reconstruction of a 'pretheoretical knowledge of a general sort' (1979: 14). Habermas focuses on the genuinely universal capabilities that define us as members of the species, but as soon as he has made this the task of a universal pragmatics he runs again into the same duality of tasks: ' $[w]$ hen the pretheoretical knowledge to be reconstructed expresses a universal capability, a general cognitive, linguistic, or interactive competence (or subcompetence), then what begins as an explication of meaning aims at the reconstruction of species competences' (1979: 14, my italics). The object of study is defined as the ability of human speakers to connect speech and reality, but we can also see that there is a whole range of empirical tasks that, as pragmatic accomplishments, cannot be reduced to the reconstruction of a general capability; instead, they can

${ }^{18}$ See also '[s]ituated utterances in general that are not specific to a given context are the object of universal pragmatics: it takes the form of a theory of communicative competence. Its task is reconstructing the rule system according to which competent speakers transpose linguistic expressions into utterances' (2001: 75, my italics). 
only be studied as empirical events in the outside world because they are successful with regard to social or linguistic expectations. Habermas thus speaks of the need to 'reconstruct the ability of adult speakers to embed sentences in relations to reality in such a way that they can take on the general pragmatic functions of representation, expression and establishing legitimate interpersonal relations' (1979: 32-3, my italics). Here, he is talking about practical accomplishments such as artistic expressions, the paraphrasing of utterances that are seen as an individual's social skills, and indeed the ability to contextually translate from and into different languages.

To be sure, some of these ambivalences can be explained away on the grounds that these are all transitional texts that do not represent definitive formulations. But, as Habermas himself contends as he discusses other authors, early difficulties in theory construction may offer also a window into more substantive challenges. In this case, Habermas seems to have been at least partly aware of this difficulty when he warns against the risk of the notion of a communicative competence becoming merely a 'hybrid concept' (1979: 26-7); that is, a category that fails to have substantive purchase. But this reinforces rather than overcomes the tension of crediting universal pragmatics with the task of reconstructing both: (1) the successful social performance of, (2) a particular anthropological competence. ${ }^{19}$ This does make Habermas's argument look like a case of central conflation (Archer 1995): rather than the interplay between two clearly distinct ontological levels - a general anthropology that is autonomous vis-à-vis social settings - Habermas seems to be eliding the human (i.e. the competence) and the social (i.e. the success of the utterances themselves). ${ }^{20}$

But it has been my argument so far that the most consistent version of Habermas's argument depends on holding on to the autonomous properties of humans as the beings who are defined by an autonomous capability whose success is however ultimately social. By the time of the publication of Theory of Communicative Action Habermas seems to have acknowledged this difficulty and narrowed down his argument in two significant ways. First, he now argues that recent developments in ethnomethodology and philosophical hermeneutics do show that we have to presuppose the idea of a universal interactive competence (for the case of ethnomethodology)

${ }^{19}$ Habermas (2003b) arguably returned to this theme later on as he built on Helmuth Plessner's distinction between being a body (as a subjective experience) and having a body (as a material thing in the world). See Alvear (forthcoming) and Schlossberger (2014) for further discussion.

20 See Krüger (1991) and Mouzelis (1992) for assessments of Habermas's argument in relation to the distinction between these two levels understood as 'action' and 'system' integration. 
and of an equally universal interpretative competence (for the case of hermeneutics, 1984a: 130). ${ }^{21}$ This demonstrates, Habermas contends, that even competing scientific programmes in the social sciences have to presuppose a similar universal human competence of this kind. Yet Habermas is also forced to concede that he is 'no longer confident that a rigorous transcendental-pragmatic programme', as the one offered by universal pragmatics, can be successfully 'carried out' (1984a: 137). In other words, the strong programme for the rational reconstruction of communicative competence remains elusive vis-à-vis the cognitive standards of modern science. Habermas even accepts that the very decision to structure Theory of Communicative Action as a theory of the rationalisation of modern society is based on the fact that such a reconstruction is 'less demanding' than the original project of a universal pragmatics (1984a: 139). The second argument refers to Habermas's early intuition with regard to the role of a theory of communicative competence for the purposes of the renewal of critical theory. In the original formulation, this revitalisation was in fact central for the justification of universal pragmatics:

for every possible communication, the anticipation of the ideal speech situation has the significance of a constitutive illusion that is at the same time the prefiguration of a form of life ... From this point of view the fundamental norms of possible speech that are built into universal pragmatics contain a practical hypothesis. This hypothesis, which must first be developed and justified in a theory of communicative competence, is the point of departure for a critical theory of society. (2001: 103, my italics $)^{22}$

As Habermas engages again with this claim in Theory of Communicative Action, doubts as to whether universal pragmatics can be put to work as an empirical research programme do not make him question its overall relevance within his project:

Linking up with formal semantics, speech-act theory, and other approaches to the pragmatics of language, this is an attempt at rationally reconstructing universal rules and necessary presuppositions of speech actions oriented to reaching an understanding. Such a program aims at hypothetical reconstructions of that pretheoretical knowledge that competent speakers bring to bear when they employ sentences in actions oriented to reaching understanding. This program holds out no prospect of an equivalent for a transcendental deduction of the communicative universals described. The hypothetical reconstructions must, however, be capable of being checked against speakers' intuitions, scattered

${ }^{21}$ See Beemer (2006) for further discussion of Habermas's account of ethnomethodology.

22 See also: a universalistic 'moral reference point must be derived from the structure in which all participants in interaction always already find themselves in so far as they act communicatively. As discourse ethics shows, a point of reference of this kind is contained in the general pragmatic presuppositions or argumentation as such' (1990a: 162-3). 
across as broad a sociocultural spectrum as possible. While the universalistic claim of formal pragmatics cannot be conclusively redeemed (in the sense of transcendental philosophy) by way of rationally reconstructing natural intuitions, it can be rendered plausible in this way. $(1984 \mathrm{a}: 138)^{23}$

We have to remember that this definition is introduced just before he begins the long march in the study of modern rationalisation processes from traditional societies to contemporary capitalist legitimisation crises. Speakers continue to be depicted as competent but the research programme itself is to be dedicated exclusively to the reconstruction of events in the world that must also be made compatible with lay actors' self-descriptions. In other words, we are still confronted with the idea that only humans (as opposed to animals) and symbolic expressions (as opposed to natural events) can be depicted as rational in a strong sense. And the reference to rule-following has now been explicitly transferred into an enquiry of how they can be reconstructed as linguistic expressions in the world. But if Habermas has watered down the idea of a general competence for the more moderate enquiry into the competent deployment of various expressions and utterances, it is then difficult to see how exactly is this interpreter different from the shallower role-bearer of conventional functionalist sociology.

\section{III}

Habermas's idea of the lifeworld is built on a tensional relationship with Husserl. At the same time as he criticises Husserl's reliance on consciousness as an obstacle for the development of a fully-fledged linguistic turn, Habermas turns to Husserl in order to reclaim the idea that, because the natural sciences are a cultural construction, they are themselves to be studied within particular lifeworlds. This does not necessarily undermine the truth-value of the natural sciences, but we need to be able to include them within a wider enquiry into the workings of the lifeworld itself. A rejection of a positivistic self-understanding of science, while remaining

${ }^{23}$ Additional proof that his trust in this programme remains intact is that Habermas's engagement with Piaget and Kohlberg takes place after the publication of Theory of Communicative Action. There, he justifies its importance not only in terms of its possible relevance for a discourse ethics but in relation to formal pragmatics itself (and including, once again, the idea of competence): 'the universalistic claims of formal pragmatics can be examined in the light of the material that developmental psychology presents in regard to the acquisition of communicative and interactive capabilities. The reconstruction of action oriented to reaching understanding would have to be suitable for describing competences whose ontogenesis has already been investigated from universalistic points of view in the Piagetian tradition' (1984a: 139, my italics). Empirical research has continued to be inspired by the Habermasian appropriation of the idea of a communicative competence. See, for instance, Abbas and McLean (2003). 
committed to their claim to validity, now requires a new theory of the constitution of the lifeworld itself; a general theory of knowledge is always more complex and general than the theory of science that arises within it. Indeed, one of Habermas's (1972) main argument in Knowledge and Human Interest was precisely that a theory of science depends on a theory of knowledge, which in turn depends on a general theory of society.

The lifeworld is then defined as a complex sociocultural web that encompasses all dimensions of everyday life. There is no single or unifying experience inside the lifeworld and this variety of modes of experiences is yet another expression of the fact that an externalist attitude that focuses, for instance, on the laws of causality that we use to describe events in the natural world, has no primacy in our everyday life. If anything, Habermas contends, it is the experience of linguistic socialisation that is truly universal: we encounter 'others' as socialised individuals with whom we establish interpersonal rather than instrumental relations. An argument that is also apparent in Hans Blumenberg's (2011) reconstruction of Husserl's phenomenology, Habermas contends that Husserl accepts the centrality of intersubjectivity in a way that Kant did not, but that the concept of intersubjectivity that he offers remains problematic. We need to go beyond Husserl if we are to explain how people experience the presence of others as persons; that is, the connections we make between the experience of a human body as a physical event in the world and the interpersonal relations we establish with fellow human beings. We owe to our communicative competence the possibility to decide when and how to exchange positions in social interaction: ego and alter see each other as identical (as humans) and distinct (in their bodily constitution, personality and sociocultural standpoints). If, on the minus side, Husserl was unable to articulate a consistent concept of intersubjectivity, on the plus side his idea of the lifeworld points Habermas in the direction of the immanent relationship between truth and society:

Every society that we conceive of as a meaningfully structured system has an immanent relation to truth. For the reality of meaning structures is based on the peculiar facticity of claims to validity: In general, these claims are naively accepted - that is, they are presumed to be fulfilled. But validity claims can, of course, be called into question. They raise a claim to legitimacy, and this legitimacy can be problematized ... We can speak of "truth" here only in the broad sense of the legitimacy of a claim that can be fulfilled or disappointed. (2001: 26, my italics)

This is a fundamental proposition for Habermas: when we make a statement, we assert it as true. Being linguistically articulated, the claims to validity of our utterances depend on our intentions and on the features of 
Table 5.1. Habermas's theory of truth and main validity claims ${ }^{1}$

\begin{tabular}{|c|c|c|c|c|}
\hline $\begin{array}{l}\text { Validity } \\
\text { claim }\end{array}$ & $\begin{array}{l}\text { Reference to the } \\
\text { world }\end{array}$ & $\begin{array}{l}\text { Paradigmatic } \\
\text { speech act }\end{array}$ & $\begin{array}{l}\text { Type of } \\
\text { discourse }\end{array}$ & $\begin{array}{l}\text { Pragmatic } \\
\text { function }\end{array}$ \\
\hline Intelligibility & Language & - & $\begin{array}{l}\text { Meta-communication } \\
\text { of grammatical and } \\
\text { pragmatic adequacy } \\
\text { of sentences and } \\
\text { utterances }\end{array}$ & Comprehensibility \\
\hline Truth & $\begin{array}{l}\text { External world } \\
\text { (nature) }\end{array}$ & Constatative & Scientific discourse & Representation \\
\hline $\begin{array}{l}\text { Normative } \\
\text { rightness }\end{array}$ & $\begin{array}{l}\text { Norms in the } \\
\text { social world } \\
\text { (interpersonal } \\
\text { relations) }\end{array}$ & Regulative & Moral discourse & Social bonds \\
\hline Truthfulness & $\begin{array}{l}\text { Internal world } \\
\quad \text { (intentions) }\end{array}$ & Avowals & $\begin{array}{l}\text { Truthfulness cannot } \\
\text { be ascertained } \\
\text { discursively but } \\
\text { through additional } \\
\text { actions }\end{array}$ & Expression \\
\hline
\end{tabular}

${ }^{1}$ Habermas's presentation of this argument can be found in (1979: 28; 1984a: 23-42; 1990a: 136-7, 2001: 63-4, 90-1). The two main modifications to the theory are: (1) intelligibility is not strictly speaking a validity claim but a precondition of communication itself and (2) truthfulness cannot be fully actualised in rational discourse but only in social contexts: '[c]laims to sincerity can be redeemed only through social life itself' (2001: 93).

the sociocultural lifeworld that we inhabit. Thus conceived, truth can no longer refer only to objective states in the world (as in the natural sciences) but must also include one's own subjectivity, as well as the justification of social norms themselves. In redefining a theory of truth in this way, Habermas no longer accepts those theories that conceive truth in terms of adequacy with the external world; he focuses instead on the rules of discourse itself. Habermas's well-known notion of validity claims that are redeemed not through intuition, intention or even interaction, but discursively, belongs here: the 'legitimacy' of validity claims 'can be established only in discourse. What is anticipated in these positings ... is not the possibility of the intuitive fulfilment of an intention, but justifiability: that is the possibility of a consensus, obtained without force, about the legitimacy of the claim in question' (2001: 34-5, my italics). There is no need here to go into the details of Habermas's argument about validity claims; for our purposes, it is enough that we summarise their main contours (see Table 5.1).

Habermas's distinction between communicative action, as the type of social action that is oriented towards reaching an understanding, and 
discourse, as the argumentative practice that focuses on the linguistic redemption of validity claims that have become problematic, is the core of his consensual theory of truth (2001: 99-100). In its original version, the argument is that, when validity claims are redeemed in rational argumentations, they refer to the adequacy of other arguments and the conditions of validity of arguments, but they do not refer directly to external evidence. In turn, this means that, for the purposes of a theory of society, we need a conception of language that not only has cognitive use (i.e. a use of language that refers to things in the world) but also has communicative use (i.e. that dimension of human communication that focuses explicitly on intersubjective relations). This is the case, moreover, because agreement over the semantic qualities of an utterance (i.e. cognitive use of language) is itself only available intersubjectively (i.e. communicative use of language):

Communicative language use presupposes cognitive use, whereby we acquire propositional contents, just as, inversely, cognitive use presupposes communicative use, since assertions can only be made by means of constatative speech acts. Although a communicative theory of society is immediately concerned with the sedimentations and products of communicative language use, it must also do justice to the double, cognitive-communicative structure of speech. Therefore, in developing a theory of speech acts, I shall at least refer to the constitutive problems that arise in connection with cognitive language use. $(2001: 64)^{24}$

It is through this dual use of language that Habermas breaks also with too narrow a model of linguistic games. The idea of language games is appealing because it accounts for the fact that rules are obligatory due to their intersubjective validity. At the same time, language games are not mere games because language constitutes us as the beings who we actually are (2001: 57). In society, following a rule implies the possibility of metacommunication over the rule itself: there has to be a human being who is able to say 'no' (1990a: 137, White and Farr 2012). But while games stop when we meta-communicate over their rules, the grammatical rules of natural languages cannot be changed or renegotiated to a similar extent: the kind of reflexivity that is involved in linguistic communication is itself linguistically articulated. In social interaction, communication always presupposes the possibility of meta-communication, but in some formulations Habermas's argument is even more demanding; he claims that the two are in fact simultaneous: 'communication through meaning is possibly only on condition of simultaneous metacommunication. Communication by means of shared meanings requires reaching an understanding about something

${ }^{24}$ Later on, Habermas will add also an expressive use of language (1990a: 137-8). 
and simultaneously reaching an understanding about the intersubjective validity of what is being communicated' (2001: 60, my italics).

If not outright problematic, this clause on simultaneity requires at least some further clarification. There is of course one sense in which Habermas is right, as human language has reflexivity and metacommunication built into it: '[b]ecause of the reflexive character of natural languages, speaking about what has been spoken, direct or indirect mention of speech components, belongs to the normal process of reaching an understanding' (1979: 18, my italics). Indeed, it is this reflexive character of language that is central to Habermas's translation of Kant's categorical imperative of morality into a discursive principle. The reflexivity of the discourse principle is as central as its inclusivity and universality: democratic discourse is one of the conditions that secures the rationality of a decision. ${ }^{25}$ At this level, the condition of simultaneity does not seem particularly problematic: if linguistic utterances are a form of action, then speech acts refer both to something in the world and to an interpersonal relation. But the argument does not really work in the first use of simultaneous above: meta-communication is always presupposed in communication, and is surely its implicit background, but this is precisely why it cannot be simultaneous with it. Habermas himself seems to recognise this much when he distinguishses between communicative action as a form of interaction that seeks to reach a rational consensus and discourse as the type of linguistic performance in which speakers have to justify validity claims that have become problematic: discourse is a form of meta-communication that is only possible when communicative action is suspended. Crucially, Habermas contends that there is no such thing as a meta-discourse (2001: 179).

There is still one further question that is worth mentioning in relation to Habermas's linguistic theory of truth. ${ }^{26}$ After twenty years in which he systematically defended the idea of a strictly consensual theory of truth that was based on the possibility of redeeming claims to validity, Habermas now contends that an adequate theory of truth cannot rely only on discursive performance. Instead, truth claims must ultimately make a reference to things in the world: 'no matter how carefully a consensus about a proposition is established and no matter how well the proposition is justified, it may nevertheless turn out to be false in light of new evidence. It is precisely this difference between truth and ideal warranted assertability that is

${ }^{25}$ Habermas's formulation of the discourse principle reads: '[o]nly those norms can claim to be valid that meet (or could meet) with the approval of all affected in their capacity as participants in a practical discourse' (Habermas 1990a: 66).

26 On Habermas's theory of truth, see chronologically: McCarthy (1973), Ferrara (1987), and Seemann (2004). 
blurred with respect to moral claims to validity' (2003a: 257, my italics). Claims to truth become more neatly differentiated from claims to normative rightness because the latter do remain wholly within the linguistic parameters of justifiability: 'assertability is what we mean by moral validity ... A norm's ideal warranted assertability ... does not refer beyond the boundaries of discourse to something that "exist" independently of having been determined to be worthy of recognition. The justification-immanence of "rightness" is based on a semantic agreement' (2003a: 258). Habermas then speaks of realism in cognitive theory - truth validity claims do ultimately refer to things in the (natural) world that exist independently of our ability to recognise them - and constructivism in moral theory - claims to normative rightness do not possess such an external locus and are wholly the result of human interaction itself (2003a: 266, Lafont 2004). ${ }^{27}$

For our purposes, the main purchase of this argument is that it further checks the potentially relativistic implication of an idea of truth that can wholly do without a reference to the outside world and is reduced to whatever statements we are able to agree on. Also, it reinforces Habermas's longstanding claim of the radical differentiation between the external standpoint of the observer that makes statements about the natural world and the internal or realisative position of participants in interactive processes: while the former allows for hierarchical forms of communication, the latter necessarily involves symmetry and reciprocity. And this is in fact consistent with a main difference between Habermas's position and those of Kohlberg and Piaget: while the latter two contend that the evolution of moral and cognitive structures follow the same pattern, Habermas contends that this is not the case and they need to be differentiated (2003a: 243-9).

But I also see two difficulties in this reworking of Habermas's theory of truth: by reasserting the need to connect consensual discourse and 'external reality', truth is now implicitly equated with technical efficiency; that is, events in the world that we can claim to have actually taken place even if we do not know how or why this is the case. Conversely, if normative rightness now needs to make no reference whatever to the world outside discourse - then

${ }^{27}$ In John Rawls's (1999b: 307) definition, moral constructivism 'holds that moral objectivity is to be understood in terms of a suitably constructed social point of view that all can accept' (note however that this 'all' explicitly refers to the members of a particular sociocultural community rather than to a universalistic conception of human beings). Moral constructivism is then based on three main pillars: (1) there can be no adequate idea of justice without an adequate idea of the person (Rawls 1999b: 345); (2) persons alone construe moral arguments because they are the source of valid claims (Rawls 1999b: 330); and (3) persons are conceived as having their own egoistic motives for action (they are 'rational') but they equally accept that cooperation is essential for these private goals to be achieved within a social order (they are 'reasonable', Rawls 1999b: 319). 
the physical, emotional and indeed moral integrity of human beings runs the risk of being dramatically undermined as a mere sociocultural construct. Yet this is not how Habermas articulates his position explicitly, for instance, in terms of the inclusivity of his principle of discourse ethics:

the unconditional nature of moral validity claims can be accounted for in terms of the universality of a normative domain that is to be brought about: Only those judgements and norms are valid that could be accepted for good reasons by everyone affected from the inclusive perspective of equally taking into consideration the evident claims of all persons. (2003a: 261, underlining mine)

A stronger theory of truth in relation to the external world cannot simply be bought at the expense of a weakened theory of normative rightness that may fall for the performative contradiction of favouring anything that may be achieved through a rational argument. And this is indeed Habermas's position as he spells out his support for universalistic ideas of human rights and dignity (2003a, 2010). It is our constitution as human beings, as beings who are simultaneously a physical event in the world and a normative source of mutual recognition, that creates a real problem. In the language of philosophical anthropology, to treat human beings as persons requires also a clear commitment to the external locus that makes possible our continuous organic existence.

This question reappears as part of a standard criticism that is against Habermas's argument: the aporias of a universalistic morality in the context of pluralist societies (Dux 1991, Taylor 1991a. See also Chapter 6). The core of this critique is well known: given that universalistic positions have originated from and are articulated within a particular sociocultural traditions, their purported universality is little else than the hypostatisation of a particular. Habermas's replies to this critique have taken several forms, but the one that matters the most once again resorts to his idea of a communicative competence: ' $[t]$ he question of the context-specific application of universal norms should not be confused with question of their justification. Since moral norms do not contain their own rules of application, acting on the basis of moral insight requires the additional competence of hermeneutic prudence, or in Kantian terminology, reflective judgment' (1990a: $179-80$, my italics). ${ }^{28}$ The point that this critique misses, and here Habermas's position is to be upheld, is that the general orientation towards neutrality, reciprocity and inclusivity that we demand of normatively legitimate social institutions is built into the very nature of human communication itself. Differently put,

${ }^{28}$ Divergence on this argument - how exactly are moral norms to be used in concrete situations - seems to be at the centre of the dispute between Habermas (1995) and Rawls (1995). 
it is one thing to contend that Habermas's position is not wholly unproblematic with regard to the justification of its own distinction between the universality of morality and the particularity of ethical life, and something different to reject the principle of universality that makes possible our ideas of autonomy, solidarity and justice.

There is, however, one key proposition that has arguably remained the same from the very start of Habermas's project: there has to be some correspondence between truth, freedom and justice, on the one hand, and the centrality of the theory of a communicative or interactive competence, on the other hand. This convergence is based precisely on the fact that it specifies the anthropological features that offer the independent justification for the social realisation of these universal values: 'justice can be gleaned only from the idealized form of reciprocity that underlies discourse' (1990a: 165). This argument on autonomy and responsibility figures centrally at the beginning of Theory of Communicative Action (1984a: 14-16), and the implications that ultimately matter to us are twofold: first, Habermas's implicit idea of human nature remains that of a 'morally neutral agent' (Papastephanou 1997: 59). While a certain 'idealism' may be found in the centrality Habermas gives to linguistic utterances, we should not lose sight of the fact that these are precisely utterances in the pragmatic sense that they can only be reconstructed vis-à-vis the wider contexts within which they are made. Not only that, Habermas's differentiated concept of truth, problematic as it ultimately is, remains committed to a differentiated account of the relationships humans establish with the external environments of the natural and sociocultural worlds, on the one hand, and their internal psychological states, on the other. Second, ideas of critique and justification remain central to Habermas's project and cannot be seen only as a property of linguistic communication. They refer also to the most fundamental anthropological capacities that we possess as human beings. ${ }^{29}$ In Habermas's version at least, the linguistic turn that made it possible to uncover the fundamentally linguistic nature of critique and justification does not change the fact they are exercised by competent subjects who have the ability to do so: justification, as the ability to give reasons becomes the counterpoint of critique, the ability to demand them.

Habermas's adoption of the linguistic turn in the early 1970s left a lasting legacy in his intellectual development. Not without its problems, the centrality of language in terms of its dual anthropological and social dimensions is a major contribution to my project of a philosophical

${ }^{29}$ See Cordero (2014b) for a full account of Habermas's idea of critique and Warren (1995) for a discussion of Habermas's idea of autonomy. we return to the questions of justification and critique in Chapter 8. 
sociology. As he thinks through the main dimensions of human language, Habermas looks for the articulation between science and philosophy, ontogenesis and phylogenesis, the cognitive and the moral, the public and the private, the internal perspective of actors and the external perspective of observers, the democratic and the technocratic, and even between different types of validity claims and rationalisation processes. Habermas's idea of a communicative or interactive competence works as the anthropological core of a universalistic principle of humanity with the help of which we bring together the different knowledge-claims of science and philosophy as necessary components of an adequate understanding of the normative dimensions of social life. 


\section{Charles Taylor}

First published in 1989, Charles Taylor's Sources of the Self makes for genuinely impressive reading. Its ambition is apparent in that it can equally be read as philosophical history of Western society and culture, a critical assessment of mainstream modern social and political thought, and an account of the various intellectual trends and traditions that have contributed to the rise of the modern idea of the self. But Sources is also the articulation of an original philosophical and normative position about the relationships between self, identity and morality in modernity. This last plane is the one on which I should like to concentrate in this Chapter: Taylor's discussion of the rise and main features of the modern self makes it possible to read this book as a significant milestone in the twentiethcentury tradition of philosophical anthropology.

Apart from its possible contribution to modern notions of the human and humanity, reading Sources as a work in philosophical anthropology can be justified on two grounds. In terms of content, first, there is an ambivalence in Taylor's usage of ideas of 'the human' that is highly instructive for the challenges faced by my project of philosophical sociology: does one retain the notion of 'the human' as a generic term with the help of which we refer to the broadest features of our species, or should one rather adopt modern, more technical, social scientific notions such as 'identity' and 'self'? Either option comes with costs: ideas of the human seem ill-prepared to handle not only their own original religious roots but they also seem to betray the thick cultural and ethical descriptions that Taylor's arguments demand. For their part, concepts of the self are, more often than not, built precisely on the kind of epistemological assumptions that Taylor criticises; above all, they presuppose the 'punctual' or disengaged individual that is arguably the major mythical construction of modern philosophy that Taylor seeks to undermine. Second, Sources can also be interpreted as a work in philosophical anthropology in terms of style, as it seeks to integrate current developments in various intellectual fields - metaphysics, epistemology, social theory, social psychology, moral philosophy and cultural and literary theory - in order to account for 
the constitutive experiences of modern life. His is not a technical book in any of these fields and yet it seeks to uphold their various standards of justification and up-to-date knowledge: this 'eclecticism' in seeking to combine philosophical and scientific traditions, in order to jointly offer descriptive and normative arguments, is again a trademark of philosophical anthropology as an intellectual tradition. Whether we agree with his general approach or not, therefore, Taylor's reconstruction of the rise of the modern self is explicitly connected to the kind of presuppositions about the human that are central to my idea of philosophical sociology: the relationships between the individual and the collective, between particularity and universality and the normative articulation of ideas of the good. ${ }^{1}$ I will not discuss Taylor's overall intellectual project in these pages. Rather, as I unpack the various components of Taylor's philosophical anthropology, I shall pay special attention to his understanding of universalism and his critique of modern proceduralism as they play a special role in what I take to be his major contribution to our purposes the idea of strong evaluations. These are constituted in the intersections between self, identity and morality itself.

I

Taylor defines strong evaluations as the 'background of distinctions between things which are recognised as of categoric or unconditioned or higher importance or worth, and things which lack this or are of lesser value' (1985a: 3). Strong evaluations are the constitutive anthropological feature that allows Taylor to delineate 'normal human agency ... what is distinctively human is the power to evaluate our desires' (1985a: 3, 15-16). Strong evaluations give shape to who we are as human beings as generic members of a species: 'the human beings we are and live with are all strong evaluators' (1985a: 28). But strong evaluations are equally relevant in our constitution as unique individuals whose particular sense of self is defined by the content of those evaluations: 'our identity is defined by our fundamental evaluations ... the concept of identity is bound up with that of certain strong evaluations which are inseparable from myself' (1985a: 34). Strong evaluations require, indeed help create, the very language with which persons express what they regard as 'higher and lower, noble and base, courageous and cowardly, integrated and fragmented' (1985a: 24).

${ }^{1}$ Earlier on, Taylor (1985a: 1) himself used the idea of philosophical anthropology as a way of describing his reflections on human nature. In Sources, however, Taylor (1989: 7) opens with a reservation against the naturalistic bias of traditional conceptions of human nature in philosophical anthropology. See Laitinen (2008) for a detailed account of Taylor's arguments from the standpoint of philosophical anthropology. 
At the same time, the very notion of a strong evaluation points to the need for distinguishing it from the interests and desires of the 'simple weigher' (1985a: 25). These weak preferences lack the reflexivity, articulacy and depth that allow strong evaluations to define 'the kind of beings we are or want to be' (1985a: 26). Taylor does not mince his words here:

the strong evaluator has articulacy and depth which the simpler weigher lacks. $\mathrm{He}$ has, one might say, articulacy about depth ... Strong evaluation is not just a condition of articulacy of preferences, but also about the quality of life, the kind of beings we are or want to be. It is in this sense deeper. (1985a: 26)

A central proposition in Taylor's work is, therefore, that the modern self is constituted through strong normative evaluations. Our sense of who we are not only depends on but is primarily articulated around those issues that deeply matter to us; and they matter not as a result of whimsical preference or the satisfaction of hedonistic desire as it would be the case with homo oeconomicus. The accreditation of how central moral motifs are for modern identity is based on the proposition that these evaluations, although they are not 'objective' in the conventional, scientific, sense of the word, they do have 'an independent existence' in the world (1989: 20). Moral evaluations have to be recognised as such by subjects themselves, but they do not emerge from subjective valuations; indeed, they are conceived precisely in contradistinction to the 'colourless subjectivistic talk of "values" that is prevalent in modern societies' (1989: 507). Taylor contends that modern ideas of normativity involve values as a way of conveying our subjective or particular experiences of the good: it is difficult to talk about morality or the normative without a reference to values. But to speak only of subjective values has become a contradiction in terms because objects of value do not depend only on subjective preferences; instead, they refer also to things in the world that are prior to, and exist independently from, subjective identification. Against its own selfconception, therefore, the modern self becomes only possible because of a pre-existing external world of moral goods. ${ }^{2}$

As we will discuss below, Taylor's position is critical of modern rationalism without being irrationalist; it is a form of ethical realism that however does not depend on a purely cognitivist approach to the

${ }^{2}$ We have also discussed these arguments in Chapters 2 and 4 and we are reminded here of Leo Strauss's critique of Max Weber's thesis that the problem of normative uncertainty in modernity is a question of the polytheism of values. In Strauss's critique, the aporia of Weber's thinking lies in the fact that he had to simultaneously presuppose the rationality of knowledge and the irrationality of normative values. But this only holds if we stick to a narrow, subjectivist view of values themselves. See Strauss (1974: 35-80) and Chernilo (2013a: 51-9) for further discussion. See Kerr (2004) for further discussion of Taylor's notion of the good. 
moral universe. ${ }^{3}$ It is also the case that, as it happens with most realist positions, Taylor equally has to face the charge of possible reification. In particular, the challenge is whether and how his position can avoid a return to metaphysical conceptions of the good. But instead of going on the defensive, Taylor's work boldly advances his own critique of modern philosophy on the grounds that it lacks a consistent moral ontology (1989: 10). We require a redefinition of the modern cosmos so that we are again, though in a different form, able to acknowledge the presence of normative considerations as an autonomous domain. In other words, we ought to grasp the specific place of notions of 'the good' in our ideas of self, morality and social life itself. Rather than being constituted from the inside out - that is, values as subjective preferences - the modern self emerges out of the reflexive articulation of objectively available ideas of the good that have a direct connection to the self's own biography. The self possesses an irreducible moral texture and, even as our identities and biographies are by no means exclusively focused on moral questions, they are fundamentally constituted by the moral dimension of strong evaluations (1989: 33-4, 42-7, 91). The key way in which this moral texture makes itself felt is through a plurality of goods that give rise to competing claims to rightness. The content of these competing claims is not wholly contingent but neither are they fixed: they change over time, are deeply personal and appeal to the world as things whose intrinsic worthiness is secured externally: 'our normal understanding of self-realization presupposes that some things are important beyond the self, that there are some goods or purposes the furthering of which has significance for us and which hence can provide the significance a fulfilling life needs' (1989: 507, my italics). Claims to rightness are therefore a key part of the dense moral narratives within which we live our lives. These actually make our moral claims intelligible as moral claims: a decision on the right course of action, a moral dilemma, an ethical controversy, they all need to be understood within the context within which they have emerged because therein lie the contents that make them such. ${ }^{4}$

${ }^{3}$ To that extent, his position is compatible with a critical realist perspective. See, for instance, my discussion of how Margaret Archer engages with Taylor's work in Chapter 7. But as we will discuss there, Taylor's approach is too restrictive from a sociological view point: empirically, the things that matter to people are of various kinds, not all of them moral or normative. But for now the argument to keep in mind is that because the normative is ultimately constituted by implicit references to what is a human being, Taylor's preference for strong moral evaluations may be justified philosophically.

${ }^{4}$ Not surprising for a Hegel expert, Taylor's (1995b) position here echoes Hegel's (1975: 75-85) own critique of Kant's ethical formalism. As we will discuss below, however, the cost of this critique seems to be a fundamentally narrow misunderstanding of the role of 
Against purely metaphysical conceptions of the good that treat these as given, Taylor claims that the moral narratives within which the modern self is articulated are socially constructed, culturally specific and dialogical in character. Because they are highly general, they can also give rise simultaneously to various normative claims and tend to remain articulated only imperfectly. Taylor (2007) calls these the background assumptions, the framework or indeed the 'social imaginaries' within which human life unfolds. These imaginaries belong to the quasi-transcendental equipment that make human life possible and any moral claim understandable: 'I want to defend the strong thesis that doing without frameworks is utterly impossible for us ... living within such strongly qualified horizons is constitutive of human agency ... stepping outside these limits would be tantamount to stepping outside what we would recognize as integral, that is, undamaged, human personhood' (1989: 27). As we have seen before, nothing short of a fundamental anthropology is at stake here because, without such explicit moral articulation, '[w]e would cease to be human' (1989: 97). These frameworks can be seen as quasi-transcendental, first, because they are the ones that allow for the configuration of actual moral positions or challenges and, second, because we cannot just turn them into the object of explicit debate (1989:31-9). What is interesting for our purposes here is that the relationships between self and the good life hinge precisely on what it means to lead a life worth calling human. ${ }^{5}$

Another feature of this soft transcendentalism is the fact that it is always and necessarily lived in the immanence of the particular: it belongs to concrete individual and socio-historical circumstances. Moral ideas are central to our personal and collective self-identity and human agency is critically defined by how these identities respond to 'some orientation to the good' (1989: 33). Things in the world become significant for the self and this is the main reason why conceptions of the good life remain key in Taylor's definition of both the self and morality (1989: 14-15, 68-76). This can of course be seen as another way of rehearsing his idea that humans are 'self-interpreting animals' who become strong evaluators (1985a: 45-75). We may call this argument the co-constitution of strong evaluations and moral goods, where the former refer to the autonomous powers of human agency and the latter describe the objective moral nature of the world itself. Strong evaluations are genuinely adequate for a moral universe that is itself autonomous.

proceduralism in modern ethical life. See Chapters 4 and 5, above, and Chernilo (2013a: 135-8) for further discussion.

${ }^{5}$ Further justification for the role of transcendental arguments can be found in Taylor (1991b: 31-41, 1995a: 20-33). 
In a formulation that reminds us of Hans-Georg Gadamer's (1989) idea of an hermeneutic circle, the status of these background assumptions depends also on their linguistic articulation. ${ }^{6}$ The relationship between self and identity is what we usually refer to as personal life and Taylor contends that this always takes place in a narrative form (1989: 47-52). It is this particular and linguistically dense context that explains Taylor's at least partial scepticism towards generic ideas of the human being; in his view, notions of the human tend to remain empty vis-à-vis our unique identities and unspecific vis-à-vis the particular locations of self. But this is only half of the story, as we have seen that Taylor is not prepared to fully abandon ideas of the human. He acknowledges that the moral sources that constitute our identities and sense of selfhood are indeed ultimately reliant on ideas of the human being: 'our moral reactions ... involve claims, implicit or explicit, about the nature and status of human beings ... a moral reaction is an assent to, an affirmation of, a given ontology of the human' (1989: 5, my italics). In other words, what makes the connection between self and good a specifically moral one is the way in which it is built on an implicit principle of humanity. The things that matter to the self create, or at least articulate, a moral outlook because they ultimately offer an image of the human; those strong evaluations are those that make a human life worth living. Even as I am taking Taylor's argument in a direction that is different from his own, this is another key intuition for my project of a philosophical sociology: strong normative orientations are based, and therefore ought to be reconstructed, around our ideas of the human. Taylor's unique contribution to unpacking what I described in the Introduction as a universalistic principle of humanity lies in his account of the relationships between a sense of self and external goods: this is precisely why it makes sense to treat people as strong evaluators who care about moral goods. As they give specific content to our lives, moral goods play a primordial role in telling us why our life is worth living: family and the nation, personal vocations and advocacy causes all belong here. We care about things whose moral texture is valuable in itself.

We now know that strong evaluations are key to human life because our sense of self is constituted primarily through the goods we value. And we have also said that, in principle at least, people are not moral fundamentalists because, while moral goods are in fact central to the constitution of the modern self, the self itself is not exclusively a moral one. While we necessarily value some goods more than others, we neither require nor

\footnotetext{
${ }^{6}$ On Taylor's relationship with modern hermeneutics, see Smith (2004). In this interpretation, the uniqueness of Taylor's position in the tradition of modern hermeneutics is the importance he gives to moral self-interpretation.
} 
operate with a single 'hypergood' that always and necessarily trumps all other possible things we care about. Taylor contends that herein lies a major gap between modern moral philosophy and sociocultural experiences of the self. On the one hand, moral philosophers tend to operate with conceptions of the good that turn themselves into 'the standpoint from which [all other moral goods, DC] must be weighed, judged, and decided upon'; yet, on the other hand, people develop a much more nuanced, tolerant and ultimately fluid relationship to what counts as an adequate moral good: humans are strong evaluators in a world of multiple moral goods (1989: 63). People are moral pluralist in a way that academic moral philosophy finds problematic - both logically and normatively. Hypergood is then Taylor's term of choice for the presupposition he thinks underpins all the meta-ethical positions that he rejects in modern philosophy; most saliently, naturalism and the various forms of ethical proceduralism from Kant in the late eighteenth century to Habermas and Rawls in the late twentieth century.

In fact, the gap between people's multiple evaluations of various goods and pretentious hypergoods that locate themselves at the pinnacle of human morality makes matters ever more difficult for people in their everyday life because our self-interpretations are not available through meta-languages (1985a: 40). Taylor's Hegelian credentials are again visible here: moral hierarchies thus constituted are unrealistic in their expectations as much as they are unhelpful in solving particular problems. Taylor accepts that hypergoods are genuinely inspired by 'the strongest moral ideas, such as freedom, altruism and universalism' but this does not change the fact that, in his view, thinkers that uphold modern proceduralism are 'caught in a strange pragmatic contradiction, whereby the very goods which move them push them to deny or denature all such goods. They are constitutionally incapable of coming clean about the deeper sources of their own thinking. Their thought is inescapably cramped' (1989: 88, my italics). The fundamental value that proceduralism promotes, but is unable to acknowledge explicitly, is a sense of 'universal benevolence' as the unrestricted possibility of good for all (1989: 260). This, in turn, is central to the egalitarian convictions of the modern age. Taylor contends that there is nothing wrong per se with benevolence and egalitarianism, nor does he see them as an ideological mask that is used to cover ulterior material interests. The problem arises when they are treated as hypergoods because then they get in the way of the more fundamental process of moral articulation between the competing goods that actually make up the modern self.

Taylor contends that this problem is largely self-inflicted by philosophers themselves because the very notion of a hypergood is a spurious 
philosophical creation: its status above other goods can never be adequately construed, let alone rationally justified. It is only the belief that hypergoods must actually exist that turns ethical and moral reasoning into a problem of obligation - whether and how we ought to follow their commands under all circumstances - and it is only on these grounds that we are led to believe that value conflicts are ultimately irresolvable. If we abandon the idea of hypergoods, with them goes also the centrality of obligation in moral theory. In turn, we may then start concentrating on the articulation of our various conceptions of the good as it actually take place in our lives. The full implications of Taylor's critique of procedural universalism will be assessed in the last section of this chapter, but we can highlight three main ideas here. First, modern proceduralism is in his view based on the wrong presupposition that one single value, or conception of the good, can adequately and definitively organise the full range of normative experiences of a modern self who lives in a complex context of multiple moral demands. Second, proceduralism concentrates on the will and obligation of an isolated individual rather than on the sociocultural traditions and attachments that constitute the modern self. A conception of the good life is always the successful articulation of competing, though not necessarily opposing, culturally dense moral narratives. Third, proponents of ethical proceduralism remain silent about how their own articulation has come about; modern proceduralism cannot explicitly justify the goods it promotes, let alone account for why it must become a hypergood. Without these three arguments, we can recast Weber's problem of values as we no longer presuppose that value conflicts are unsolvable: gods are not always at war with each other - they do not demand absolute loyalty and their demands are not necessarily incompatible.

Modern proceduralism is of course not the only available position in modern moral philosophy, but alternative moral theories are equally if not more problematic, Taylor contends. Power theories, as they transpire in Nietzsche's transvaluation of values and Foucault's genealogy, are right in unpacking the underlying motifs that remain hidden in ethical proceduralism and also in showing the substantive contents on which they are based but cannot openly declare. Indeed, the major impact of Nietzsche's thesis on the transvaluation of values lies precisely in having uncovered the aporia that comes with any notion of the hypergood: all claims to offer an ultimate standard are negated in practice by the various conflicts that arise between standards; the claim of being able to orient all value decisions is negated by the very moral conflicts that they actually trigger (1989: 65, 99). But in Taylor's view, Nietzsche and Foucault's critiques are flawed even in their own terms because all they are able to see is a conflict between moral claims which are all equally unwarranted as moral claims. 
For them, normative conflicts do not exist because there is no independent normative realm at all: their rejection of modern proceduralism as an inadequate moral ontology leads them to abandon altogether the possibility of a consistent moral ontology. In turn, this makes their normative stances simply unintelligible: where does the relevance of laying bare unwarranted moral claims lie if there are no genuine normative motifs in the first place? As they rightly uncover that power claims can underpin moral arguments, they wrongly conclude that all moral claims are power claims in disguise - in effect, that there is no such thing as moral claims. As they reject any possible idea of an objective good, they turn out to be as reductionist as the proceduralism they criticise. ${ }^{7}$

In addition to proceduralism and theories of power, Taylor also discusses a third position in contemporary moral theory. Best articulated in modern epistemology than in moral philosophy itself, he uses the term naturalism to describe an attitude that sees ethical questions as exempt from the need for further articulation. ${ }^{8}$ Utilitarian positions are the main representative of this strand because the 'good' and the 'bad' to which they make reference seem to be traced back, unproblematically, to both our own personal preferences and the 'universal benevolence' of the greater numbers (1989: 260-84). Their ideas of the moral good fall short of Taylor's position because what counts as moral here is wholly dependent on the subjective point of view of the simple weigher: strong evaluations become impossible because there is neither sociocultural or biographical articulation nor an objective moral universe. In their suppression of substantive moral goods, contends Taylor, naturalism and proceduralism complement rather than oppose one another: 'freedom and epistemological suspicion of strong goods bind together utilitarians and naturalists of all sorts, as well as Kantians' (1989: 84). Ethical naturalism shares with modern proceduralism a concern with human dignity and the avoidance of suffering, and these otherwise different positions also share the fact that, rather than being neutral, the values they promote depend on the moral vocabularies within which they have been articulated $(1989: 8,57) .{ }^{9}$

${ }^{7}$ Taylor concludes that the postmodern position in ethics is 'delusionary' (1989:504). This is a similar argument to the one that I offered in the Introduction against the inconsistencies of contemporary posthumanism: if the human is little else than a fiction, where does the normative motivation to 'put things right' come from? Postmodernity's normative claims are, Taylor contends, ultimately self-destructive (1985a: 7).

${ }^{8}$ As we will see, Taylor uses naturalism as a key term to emphasise all that is wrong with modern human and social sciences. This somewhat reductive use of the term has not gone unnoticed by critics (Dreyfus 2004), and indeed Taylor accepts that his use of the term may be somewhat unfair (1989: 332). Against this reductionism, see my arguments in Chapters 3 and 4.

${ }^{9}$ In relation to the problem of anthropocentrism, Taylor contends that a consistent naturalist position has the additional feature of being anti-anthropocentric. In this case, the argument 
Moral evaluations become meaningful because they appeal to conceptions of the good rather than because they follow abstract procedural rules or meta-ethical principles; they are relevant because they allow for the articulation of real dilemmas rather than because they make it possible to reduce all moral conflicts into one. Moral decisions motivate rather than push the individual to act in a particular way and, because of that, they construe justifications for the course of action that has been chosen. Moral articulation needs to remain meaningful for the self in its own context and symmetrical vis-à-vis other normative positions because moral knowledge allows for no position of privilege. Thus conceived, Taylor's conception of the good life avoids being turned into a hypergood because, rather than the triumph of a particular conception of the good which is then used to organise social life as a whole, it primarily consists in the satisfactory articulation of the various moral demands that are present in one's biography. Individuals constitute themselves through the evaluations that they make. A soft version of a hypergood seems to re-emerge within Taylor's own position, however. He gives pride of place to those 'constitutive' goods that are not only able to orient action but render further goods worthy of pursuit. He defines these constitutive goods as 'something the love of which empowers us to do and be good. And hence also loving it is part of what it is to be a good human being' (1989: 93). Constitutive goods are different from hypergoods because they are not abstract rules; instead, they need always to be articulated within particular lifeworlds and through personal motives. Constitutive goods are unique because of their transitive quality: they elicit our attachment to further goods and thus provide a more sensible way of ranking various goods. Whether Taylor is partly backtracking on his previous critique of proceduralism will be assessed more fully below. But for now we still need to get a more complete picture of the, to my mind problematic, ontological underpinnings of his argument:

because we cannot but orient ourselves to the good, and thus determine our place relative to it and hence determine the direction of our lives, we must inescapably understand our lives as a "quest". But one could perhaps start from another point: because we have to determine our place in relation to the good, therefore we cannot be without an orientation to it, and hence must see our life in story. $(1989: 51-2, \text { my italics })^{10}$

is that naturalism need not be rejected but fundamentally regrounded (1985a: 2-3, 7). See Chapter 1 and the Epilogue.

${ }^{10}$ Interestingly, Richard Rorty (1994:20) remains unconvinced and contends that Taylor is committed to his own theory of moral 'hypergoods', not least because Taylor's constant recourse to a language of moral absolutes may be construed as a form of fundamentalism. Conversely, one may show that John Rawls (1999b: 312-15), for instance, also speaks of primary goods that are not hypergoods because they allow for the further organisation of personal interests in society. 
Taylor emphasises here one side of his argument that we have encountered already: because all ideas of the good actually take historical and narrative form, we can only form our identities through the dense moral narratives thus constituted. This is what makes our moral orientation a quest in the strong sense of the term - not least in terms of the theological and teleological implications of seeing it as a project where the subjective and the objective are expected to come together. But in this last quotation I have highlighted an additional argument that, although it does not get systematic treatment in Taylor's own account, for my purposes is at least equally important: why does the self 'have to' orient itself necessarily to the good? How does the self attain certainty that a good is indeed such? Can our strong evaluations be fundamentally wrong? How do we deal with opposite visions about whether a particular moral good is indeed a good? There seem to be at least two sets of issues at stake here: first, there is the question of Taylor's critical position towards universalism and his narrow conception of naturalism. ${ }^{11}$ Second, we need to consider whether Taylor's claim of an automatic congruence between self, good and morality leads him back to the kind of metaphysics he had sought to leave behind through his argument about the social, cultural and historical articulation of moral goods.

\section{II}

For all its philosophical depth and sophistication, Taylor's account of the socioeconomic trends that have given rise to modern societies is remarkably conventional. Taking the 1800 s as the key transition point that marks the rise of modernity, Taylor argues that 'Western', 'liberal' or 'bourgeois' modernity is fundamentally marked by 'the slow spreading outward and downward of the new modes of thought and sensibility to new nations and classes, with the transfer in each case involving some kind of adapting and transformation of the ideas themselves' (1989: 394). These major ideas that spread all over the world (outwards) and to lower social classes inside Western nations (downward), are the three themes that organise the bulk of the historical exposition in Sources. First, a sense of inwardness that is constitutive of modern notions of the individual. This notion of an inner depth is what allows mechanistic separations between subject and object, mind and body,

${ }^{11}$ We will come back to these questions at the end of the chapter, but think, for instance, whether Taylor's critique of Habermas fails to engage with Habermas's own conception of the lifeworld. Whatever one may think of Habermas's substantive argument about the constitution of the lifeworld, his main point remains: all universalistic positions now take place within particular sociocultural lifeworlds. For a more nuanced critique of Habermas, see Taylor (1991a). 
or consciousness and the world. Second, a new valorisation of ordinary life so that traditional ideas of the good life - participation in public life, honour in the battlefield or the philosopher's contemplative life - become replaced by those domains that are more salient in modernity: economic life, technological success and the spheres of intimacy and family life. Third, a rediscovery of expressive nature, in the dual sense that 'pristine' nature becomes a major source of inspiration and that the inner life of the individual must find a way out to the world through aesthetic expression.

A more or less coherent picture of the modern world obtains from the combination of these three trends: an objectified vision of the outside world that is open to unrestricted human manipulation, a flattening of all social domains as being of equal value for individual as well as for collective life (modern societies have no single sphere that acts as its 'centre'), and an equally one-sided representation of the autonomous individual who is selfsufficient and for whom finding her inner voice may become a major purpose in life. The modern world develops an anthropocentric selfconception through an ultimately inconsistent combination of naturalistic objectivism and radical subjectivism. ${ }^{12}$ Given that Taylor's primary concern is to explain the rise and main features of modern notions of the self, the route towards radical subjectivism is the one he explores at greater length. The modern ideal is that of a subjective will that is fully independent from the external world in its constitution and is equally autonomous from it for the fulfilment of its projects. The modern, 'punctual self' that Taylor reconstructs entails self-control and self-love (Locke's utilitarianism), self-reflection (Descartes's cogito), self-sufficiency (Leibniz's monads), self-determination and freedom (Kant's categorical imperative of morality and Rousseau's general will) and self-esteem and self-expression (Montaigne's interiority and Bacon's practical sense). Taylor (1989: 175-6) summarises his object of critique thus:

The philosophy of disengagement and objectification has helped to create a picture of the human being, at its most extreme in certain forms of materialism, from which the last vestiges of subjectivity seem to have been expelled. It is a picture of the human being from a completely third-person perspective. The paradox is that this severe outlook is connected with, indeed, based on, according a central place to the first-person stance. Radical objectivity is only intelligible and accessible through radical subjectivity.

The individualism that is central to the rise of modern culture and institutions seems to have been first articulated in the modern tradition of natural law which, since the seventeenth century, has changed the ways in

12 See Rosa (1998) for further discussion of how Taylor's critique of naturalism and emotivism mirror one another. 
which new social and political commitments are framed as subjective rights (1989: 305). A later source for this radical subjectivism is the expressive view of human life whereby artistic epiphany - primarily for the creator but eventually also for the spectator - becomes 'genuinely mysterious, and it possibly contains the key - or a key - to what is to be human' (1989: 481). But the importance of the artist and of the work of art in modernity go beyond the aesthetic as a self-contained domain and becomes deeply spiritual; it also accounts for the modern obsession with originality as central to expressivism and its idea of the inner voice (1989: 375-6, 1991b). To locate, as Taylor does, seventeenth-century natural law theory at the centre of the intellectual transformations that gave rise to modern social and political thought is now relatively unproblematic in the philosophical literature (Hochstrasser 2000, Schneewind 1998). ${ }^{13}$ But the same cannot be said in relation to social scientific literature for which the rise of sociology and modern social science in general is seen as a result of the French and American Revolutions (Giddens 2003). The more conventional view here remains that the emergence of sociology as empirical political philosophy meant the rise of a scientific programme that was openly opposed to modern natural law theory from Grotius and Puffendorf to Hobbes, Rousseau and Kant (Wagner 2006). The argument here is really twofold: first, against the social scientific mainstream, Taylor rightly contends that seventeenthcentury natural law theory is or at least was central to the rise of the modern normative imagination. In reading this tradition as a form of radical individualism that seeks to foster a wholly detached sense of individual autonomy, Taylor explicitly echoes the mainstream position that its key feature lies in its possessive individualism (Macpherson 1964). Second, however, the counterargument can be made that one main reason that explains why seventeenth-century natural law theory is in fact central to the rise of modern sociology is precisely because it does not offer a wholly individualistic argument; rather, it is itself an attempt to explain the rise of modernity as the articulation of the descriptive and normative claims, individual and collective life, natural and social domains. Even if there is no space to address this debate in full here, I would briefly like to make one comment in this regard. In relation to Kant, for example, Taylor contends that Kant's formalism is based on a complete rejection of the idea of human nature as having any empirical determination (1989: 83, 363, 1985b: 318-37). The strictures of the categorical imperative of morality are there precisely to make it stand not only above but also against individual desires and particular inclinations. But the argument can be made that this is not Kant's position at all, and that the categorical imperative was in fact a way

${ }^{13}$ See Taylor (1989: 11-12, 82-6, 106, 193-5 and 2007: 3-22). 
to mediate between our particular inclinations and the necessary decentring of the same individual perspective which then allows for its generalisation (see Chapter 2). Even if Kant did not fully succeed in this attempt, the point is precisely that he tried to break away from previous natural law because he sought to construe moral arguments through the mediation of the things that matter to me as an individual and those that matter to everyone as members of the same species (Chernilo 2012a). ${ }^{14}$

The Enlightenment plays a particularly salient role in Taylor's assessment of modernist thinking and he contends that, through its emphasis on naturalistic epistemology, one of the Enlightenment's main insights is that the cosmos has been wholly depopulated of ideas (1989: 382-3). From the standpoint of normative thinking, this means the creation of a humanist position that contradicts itself because it is based on a purely naturalistic account of human beings themselves. This is a form of reductionism because it adequately accounts for neither the human soul within the natural universe nor human beings' own worthiness within society. While the idea of pristine and autonomous nature was more or less consensually seen 'as the source of right impulse or sentiment' (1989: 284), the substantive determination of that source remained a deeply divisive issue: it might reside in the self's interior life (and thus be based on reason or sentiment), but it can also come from the outside and be grounded on providential design or indeed the artificial environment that is society itself: ' $[\mathrm{n}]$ aturalism neutralizes nature, both without us, and in ourselves' (1989: 383; see also: 175, 336-40).

We have said already that the critique of ethical proceduralism figures highly in Taylor's argument and we can now see that its relevance lies deep as one of modernity's constitutive moral insights. Rather than being opposed to modern naturalism, Taylor contends that moral proceduralism builds on its contentious premises. More precisely, proceduralism adopts the key naturalistic proposition that all aspects of human life can be accounted for in the same mechanistic way that best applies to the natural sciences; namely, the idea that some descriptions are objectively better than others on the basis of an external criterion on which everyone must agree. The very achievement of such criteria - the argument is directed explicitly to both the scientific method and Kant's categorical

14 Incidentally, C. B. Macpherson's depiction of seventeenth-century natural law theory as 'possessive individualism' is also shared by writers in the tradition of critical theory. Here, Hegel and Marx are the ones that seem to offer the much-needed but always elusive rupture with modern natural law (Marcuse 1973, Rose 2009). Indeed, Taylor's sympathies also lie with Hegel on this: 'The Hegelian battle is never between good and bad, but between two requirements of the good; and it issues in synthesis, not total victory' (1989: 388). This is undoubtedly correct, but in my view Hegel here builds on rather than breaks away from Kant (Chernilo 2013a: 121-45). 
imperative - is itself seen as part of a rational learning process that makes it necessary to abandon previous beliefs that have now become demonstrably false: '[e]pistemology and moral fervour are mutually supporting' (1989: 405). A key tension upon which all modern moral theories have to dwell is, Taylor contends, the dual affirmation of ordinary life, on the one hand, and the strong assertions about the things we deeply care about, on the other: '[w]e sympathize with both the hero and the anti-hero; and we dream of a world in which one could be in the same act both' (1989: 24). The ordinary of everyday life and the extraordinary of exceptional actions both make normative assessment very difficult for modern moral theory.

In ethics, proceduralism works on the presupposition that we can determine moral goods with independence from how the rest of our evaluations appear and are articulated in everyday life; proceduralism is said to focus only on purity and consistency as it contends that only one answer can be right at any single time. Proceduralism grows available in all realms of life because reason is not allowed to discover or uphold any substantive conception of the good - it depends exclusively on formal reason (1989: 67-74, 243). The metaphysical certainties that we have lost in terms of old moral truths are to be compensated by epistemic gains: we now have the whole universe at our disposal for human exploration and can openly discuss those different sources of the good which will eventually be arranged in a solid manner through the organising prowess of the procedure itself. We mentioned that Taylor echoes here the common trope that the values that make modern proceduralism possible cannot be accounted for procedurally. $\mathrm{He}$, however, traces these criticisms back to its substantive historical roots in the Enlightenment: disengaged reason, creative imagination, individual freedom, human dignity, subjective rights, expressive selffulfilment and natural benevolence and justice (1989: 503). In a different language, Taylor's argument shows one particular form that the interconnections between description and normativity have taken in modern societies: it is as though the 'scientific' laws of nature have necessarily to coincide with those 'moral' natural laws of humanity.

Ultimately, if these different factors appear to be self-accommodating vis-à-vis the alleged neutrality of ethical proceduralism, this is because we uncritically uphold the idea that individual and collective interests can be harmoniously accommodated within society and indeed worldwide. More dramatically, and following the post-Heideggerian tropes that we have encountered several times before, Taylor contends that this fanaticism lies at the roots of modern experiences of terror $(1989: 330,387) .{ }^{15}$

${ }^{15}$ It is interesting that Nicholas Smith (2002: 1) resorts to similar existentialist motifs when he describes Taylor's general approach as one that seeks to grasp the fact that human 
We live under the 'moral imperative to reduce suffering', but we now need to do this after we have lost our innocence in the possibilities of accommodating individual and collective interests (1989: 394-7). Even as we accept that modern bureaucracies create their own injustices, Western societies still see themselves as morally exceptional vis-à-vis other cultures and previous times: ' $[\mathrm{h}]$ owever unsuccessful mankind has been in attaining "the blessings and security of self-government", no other aspiration ultimately incompatible with this is now available' (1989: 396). Having made an important contribution to the debate on multiculturalism, it is noteworthy that Taylor argues that the perennial moral dilemmas of modern times are not so much a result of the increase of normative pluralism but actually result from the growing inability to articulate moral ontologies adequately (1994). It is questionable however whether we can actually separate these two arguments: at the very least, consistent moral ontologies have become more challenging to articulate because of the extent to which they are exposed to normative pluralism. We move, Taylor argues, between universalistic platitudes - a rather bland obligation to others, avoidance of suffering, universal benevolence and dignity - and a sense of individuality that effectively undermines any possible attachment. The moral perplexities thus constituted appear then to give credence to several moral positions in modernity - not least because they are mutually incompatible. The highly incoherent coexistence of utilitarian naturalism, Kantian formalism and postmodern relativism demonstrates that they cannot orient the modern self. Taylor is decidedly committed to the idea of an objective moral universe that humans are able to grasp through their anthropological capacity of strong evaluations. Yet he rejects the idea that these moral intuitions can be translated into some impartial or neutral account of that world. Even if the charge of relativism does not really apply to Taylor's position, there is something deeply troubling in the fact that his critique of naturalism goes against ideas of objectivity and external reality and yet, simultaneously, the universe we inhabit is unequivocally described as oriented towards moral goods. ${ }^{16}$

\section{III}

If we now turn to a more critical assessment of Taylor's key arguments, a first line of enquiry has been raised by Hans Joas (2000: 141): it is hard to see how Taylor's own philosophical project emerges out of the same philosophical tradition he has critically reconstructed. Indeed, this can be

beings are 'condemned to meaning'. See, however, Taylor's critique of existentialist morality, and of Sartre in particular (1985a: 29-35).

${ }^{16}$ See Taylor (1985a: 45-56) and Rosa (1995) for further discussion. 
addressed as a methodological question - how is Taylor's philosophical history of modernity being construed? - but it is also a substantive one: having been so critical of the modern philosophical tradition, the intellectual sources for his own project still require further elucidation. ${ }^{17}$ Taylor is to be praised for avoiding the kind of claims to originality that are so pervasive in contemporary debates and yet he offers little in terms of an actual self-positioning of his philosophical project. Taylor's explicit assessment of modern Western philosophy is extremely critical and his narrative becomes a teleological one that leads to the regressive reductionisms of naturalism and emotivism. The argument in Sources is arguably best read as a critique of the unilateral and ultimately excessive importance that inwardness, expressiveness, naturalism and the everyday have had in modern moral philosophy rather than as a thorough rejection of them. Taylor does not fall for a sense of philosophical culmination so that the trajectory of modern philosophy reaches its pinnacle in his own work. But this lack offers a strange sense of a 'punctual' philosopher who does not really engage with the positive sources of his own moral ontology. Differently put, Taylor's theory of the self as a strong evaluator of objective moral goods has had to emerge, at least partly, out of the same sources that he criticises: Taylor's self is one who can see the world for what it is, whose moral compass is based on everyday life experiences, for whom the natural world exists without reifying it and yet it is also a self who above all is able to organise all these through infallible strong evaluations. Whether this criticism goes to the heart of Taylor's argument, or it rather remains a methodological one, can be said to depend on whether he is ultimately able to offer a clear account of the thick cultural traditions within which this cosmology has emerged and, quite crucially, how they connect to the prevailing consensus he has just deconstructed. ${ }^{18}$

An additional question has to do with the universalistic underpinnings of the idea of strong evaluations. To the extent that Taylor treats strong evaluations as that species-capacity that defines normal human agency, and that the very possibility of talking about a human identity is based on people being in possession of strong evaluations that refer to substantive moral goods, there can be no question that he does see it as a general anthropological property. But given that strong evaluations are also defined in opposition to the weak preferences and dispositions of the

${ }^{17}$ A similar critique has been made against Karl Löwith's (1964) argument Meaning in History: if his historical reconstruction describes a process of increasing secularisation, it is not altogether clear what are the intellectual resources Löwith can actually draw from so that he $i$ able to step outside of the very historical trends that he is describing. See Barash (1998).

18 Taylor's (1995b) extensive discussion of Hegel as his intellectual hero remains only partly useful in this case. While a Hegelian assessment of the philosophical tradition is of course available to Taylor the scholar, this is the same 'Hegelianism' that Taylor's Sources shows to have been defeated for the purposes of significant sociocultural articulation. 
simple weigher, the door is not wholly shut to some form of elitism whereby greater humanness is attached to those who commit, say, to altruistic causes. Taylor's argument that the simple weigher lacks the depth, reflexivity and articulacy that can only come with strong evaluations is unsatisfactory - both descriptively and normatively.

At the beginning of this chapter, I commented on Taylor's argument of a moral cosmos that is populated by autonomous conceptions of the good and of a self whose very humanity depends on its ability to recognise these goods as goods (and thus becoming attached to some or indeed several of them). Cosmos and self encounter one another through the intersubjective articulation of these goods in the thick cultural backgrounds within which people construe their strong evaluations. No argument has been given, however, on how or why the self's strong evaluations and objective moral goods attract one another. Taylor's argument that I quoted above that 'we cannot but orient ourselves to the good' does not work sociologically. As mentioned, the philosophical foundation of this argument is that no social order can be established outside a moral ontology, that all moral ontologies uphold a plurality of goods and that, at this collective level, goods do prevail over evils. As individuals make these traditions their own, they recognise that they are preceded by them and grow up within them. But after the experiences of modernity this is deeply problematic: how are we to account for socialisation under Nazi Germany or the apartheid regime? Obviously, Taylor is not going to conceive extreme forms of racism as a moral good, but then he must explain how is it possible that racism can reach a position in which it is treated as one; he ought to explain how, in his own language, evil may also hold together self and the moral order. It looks as though Taylor still has two other options - although neither leaves him in a better position. A first option is to secure the virtuous connection between self and world on theological grounds. This may be acceptable to Taylor on the basis of his personal religious beliefs, but cannot be justified on sociological, historical or even philosophical arguments. ${ }^{19}$ Interestingly, these religious commitments may go also to explain the philosophical sources that remain partly unaccounted for within his work. ${ }^{20}$ A second option would be for Taylor to argue, or at least accept, that connections between self and cosmos are pre-programmed biologically, but this is of course an

${ }^{19}$ On Taylor's reliance on religious arguments, see $(1989: 317,352,506)$. The difficulty with arguments that imply religious commitments is that their justifications for the position of values remain speculative rather than strictly philosophical. At times, we are even left with the impression that Taylor cannot really transcend the modern emotivism he quite rightly criticises: we are 'moved', he says, by certain goods 'as something infinitely valuable' (1989: 74) See also Joas (2013).

${ }^{20}$ See, for instance, Paul Tillich (1964). 
argument that runs against Taylor's own critique of modern naturalism. It is then worthy of mention that Taylor's critique of naturalism as a possible source for moral thinking is in fact not far apart from two key arguments that we found in Hans Jonas's own ethical naturalism: on the one hand, the modern idea of a normative-less cosmos is inconsistent and, on the other, moral arguments that create obligations are ultimately based on existence and not on rational justifications. Taylor's (1989: 77) proposition that 'articulating a vision of the good is not offering a basic reason' may be seen as compatible with the first part of Jonas's (1984: 39) imperative of responsibility that 'requires no deduction from a principle'. We have seen that Jonas's answer is problematic in its own right. Yet it does have the advantage that it poses the problem more radically because Jonas explicitly states that we can only dispense of reason as the foundation of morality because a sense of the good 'is powerfully implanted in us by nature' (Jonas 1984: 39). While still amenable to hermeneutical appropriation within one's own cultural traditions, this conception of moral goods is altogether different from the cultural narratives that Taylor speaks about. Perhaps counterintuitively, Jonas and Taylor share the dogmatic infallibility that is constitutive of any argument for which the self cannot but orient itself to the good. But whereas Jonas offers the imperative of responsibility as a formal criterion with the help of which we can assess moral questions, we have seen that Taylor rejects ethical formalism altogether. ${ }^{21} \mathrm{~A}$ form of essentialism seems to take over Taylor's phenomenology of morality (Joas 2000: 143).

Taylor sides with Arendt's criticism that Kant's categorical imperative of morality reproduces the premises of the utilitarianism that it seeks to overcome. In Taylor, however, this is presented through a reading of Kant whereby the categorical imperative is seen as articulating exclusively a concept of negative liberty. To an extent, this was of course Hegel's critique of Kant: 'Kant's moral autonomy has been purchased at the price of vacuity' (1995b: 371, my italics). ${ }^{22}$ Taylor rightly defends Hegel's ideas of spirit, Volksgeist, state and community against the charge of totalitarian implications, but if this is in fact the case, then these same atrocities of the twentieth century show that Hegel's original critique of Kant's formalism has itself missed the point: the radical humanism of Kant's categorical imperative cannot be made responsible for the cruelties that may (or may

${ }^{21}$ Interestingly, Jonas's rejection of Kantian morality while adopting a procedural formalism of his own speaks in favour of Taylor's argument that moral Kantianism and naturalistic epistemology reinforce one another. This is another dimension in which Jonas misses how much his argument mirrors Kantian ones. See Chapter 4.

22 The idea of vacuity to describe Kant's moral theory appears four times in the following pages (1995b: 373 and 375). 
not) have been committed on its behalf. Taylor's assessment of Hegel shows the constant themes of the communitarian critique: rampant individualism and modern bureaucracy turn everything into means and ends. But he then becomes unable to find any positive normative content within modern institutions because of the reductionist understanding of Kantianism itself (1995b: 365-88, 537-46). Pace Hegel and Taylor, the normative force of Kant's proceduralism is anything but vacuous: belonging as it does to the realm of pure practical reason, the normative purchase of modern ideas of autonomy and self-determination are to do with the possibility of individuals developing a moral compass and not with logical integrity. Taylor is too quick in his dismissal of the normative content of universal ideas of humanity.

Somewhat ironically, I suppose, at the beginning of Sources Taylor contends that, with regard to questions of the dignity and integrity of life, 'we are all universalists now' (1989: 6). To an extent, this seems to mean that several of our modern institutions - free speech, political self-determination, equality before the law and negative liberties - are indeed built around ideas of human dignity and universal benevolence. Yet they are also described as the rather empty universalism of 'post-Enlightenment banalities' (Taylor, cited in Joas 2000: 123). I wholeheartedly disagree: Taylor's philosophical critique of this form of universalism is possible, indeed presupposes in a fundamental sense, that there are some universalistic principles that he can take for granted as they have become institutionally secured in 'the West'. I do not want to raise the criticism that Taylor's arguments are Eurocentric, not least because rights to freedom of expression and privacy remain highly important and are being contested everywhere in the world. But these universalistic ideas suddenly become far less banal if we accept that, twenty-five years after the original publication of Sources, some of these values themselves just cannot be taken for granted - in 'the West' as much as everywhere else in the world. From detentions without charges to practices of sexual mutilation, from equal marriage to institutional racism, from the legal duties towards refugees to the threats of global warming, universalistic arguments that are based on our common anthropological features as human beings are neither banal nor can they be taken for granted.

Taylor is not taken aback by the modern challenges of normative pluralism and transcultural visions of the good. There is no single or allencompassing moral framework that is universally accepted and Taylor rightly points out that this does not lead automatically to value incommensurability:

we can, in principle, understand and recognise the goods of another society as goods-for-everyone (and hence for ourselves). That these are not combinable 
with our own home-grown goods-for-everyone may indeed be tragic but is no different in principle from any of the other dilemmas we may be in through facing incombinable goods, even within our own way of life. (1989: 61)

\section{It is therefore acceptable to speak of these goods-for-everyone}

provided we afford the same status to those of other societies we are trying to understand. This does not mean of course that all our, or all their, supposed goods will turn out at the end of the day to be defensible as such; just that we don't start with a preshrunk moral universe in which we take as given that their goods have nothing to say to us or perhaps ours to them. (1989:62)

It is not only possible but actually essential that, as we come to recognise and then assess different normative positions, we see some of the goods on display as actually goods-for-everyone. Normative conflicts or misunderstandings are as possible within a cultural tradition as they are among them. To the same extent that we fully appreciate that there may be conflicts between values, we do not have to anticipate as a conclusion that values will necessarily refute one another. This is precisely the argument in the conclusion to Sources:

What emerges from the picture of modern identity as it develops over time is not only the central place of constitutive goods in moral life . . . but also the diversity of goods for which a valid claim can be made. The goods may be in conflict, but for all that they don't refute each other... Close and patient articulation of the goods which underpin different spiritual families in our times tends, I believe, to make their claims more palatable. (1989: 502, my italics)

But if this is ultimately the case, then we are not far from the type of regulative role of universalistic ideas that I am advocating in this book. Indeed, in order to turn these values into moral goods, we need honest critical examination of our own position and increased self-awareness of each other's blind spots. Taylor's normative optimism on this count, which I share, depends not only on the possibilities of intercultural dialogue (Chernilo 2012b). But I should think that it also requires, against Taylor's position, some form of proceduralism; otherwise it is not clear how this good-spirited reflexivity will work - let alone be seen as enough for the progressive widening of our moral compass. If, as Taylor contends, possibilities for normative understanding are to remain open - and the fact that they are is an empirical claim rather than a normative one - then we also need a bolder proposition about how this is going to work. And for us to do this proceduralism remains key.

It may be argued that Taylor's normative optimism is skewed because of his commitment to a positive relationship between self and the good. Even if we put to one side the quasi-theological objection of whether evil is 
indeed real, a sociological challenge remains: normative pluralism and the logic of unintended consequences still leave us with the dilemma that genuine commitments to moral goods translate into perverse or even evil consequences. As he reflects on the various sources of fanaticism in modern times where evil prevails over good, the grounds on which Taylor can justify his opposition to, say, totalitarian or anti-democratic regimes, are hard to pin down if we remain confined to a rejection of universalism and the opportunities for self-clarification that are afforded by modern proceduralism. Thus, after referring to the lost normative opportunities during the Nuremberg trials - the cynical use of power even in the face of the worst possible atrocities - Taylor's reflections express a clear tension: because we can delude ourselves about our good motives,

[t]here are good reasons to remain silent. But they cannot be valid across the board. Without any articulation at all, we would lose all contact with the good, however conceived. We would cease to be human. The severest injunctions to silence can only be directed to certain classes of articulation, and must spare others. The issue is to define which ones. (1989: 97, my italics) ${ }^{23}$

That no form of universalistic proceduralism is allowed in even after admissions of this kind remains a form of dogmatism on Taylor's part. Given that at stake is a form of permanent and open-ended dialogue whose output can be nothing but the tentative and temporary articulation between various goods, then there is no definitive objection to the proposition that the type of procedure involved will itself be a matter to be agreed on. Democratic deliberation in the public sphere (Habermas), universalisation of personal preferences (Kant), counterfactual anticipation of an egalitarian starting point (Rawls) or restraint in the use of natural resources in order to allow for the future continuation of human life (Jonas), all asymptotically point towards an idea of goods-foreveryone that is not based on homogeneity but on human plurality itself. Because some strong evaluations are better than others, no definitive rejection of proceduralism is needed.

${ }^{23}$ Taylor's need for silence has also been interpreted as being religiously inspired: a sense of transcendence that is beyond linguistic, let alone conceptual, articulation (Connolly 2004: 169). It is interesting, however, that Taylor uses the religious sources of modern proceduralism as an argument against it: '[w]e make the link between procedure and truth with the proof that we are the creatures of a veracious God ... Rationality is now an internal property of subjective thinking, rather than consisting in its vision of reality' (1989: 156). 


\section{$7 \quad$ Reflexivity \\ Margaret Archer}

A defining feature of Margaret Archer's sociological project since the late 1980 s has been the centrality she gives to the relationships between 'structure' and 'agency'. While this is not in itself an original claim, only Archer has arguably devoted a trilogy to advance a systematic understanding of 'culture' (Archer 1988), 'social structures' (Archer 1995) and 'agency' (Archer 2000). In these books, she offers not only a positive account of each of these domains in its own right but also, and equally importantly, she discusses their interrelationships.

When contemporary sociologists emphasise the importance of structure and agency as the discipline's key dichotomy, the argument is usually made on cognitive grounds. They are all more or less agreed on the idea that at stake here are the conceptual, epistemological, methodological and even ontological implications that this tension poses to social theorising and to empirical research (Elder-Vass 2010, Mascareño 2008, Mouzelis 1995). The problem of structure and agency then becomes one particular way in which contemporary sociological theorists refer to the tensional relationships between, say, sociology's older debate on action and system theory (Parsons 1961), social and system integration (Habermas 1984a, Lockwood 1992) or indeed micro vs macro (Alexander et al. 1987). ${ }^{1}$ None of these debates coincides exactly with the one between structure and agency, but the main reason that explains why it resonates within the discipline, it seems to me, is because it simultaneously touches on such perennial dilemmas as objectivism and subjectivism, positivism and historicism or hermeneutics, and indeed the 'external' perspective of the scientific observer and the 'internal' perspective of lay actors themselves (see also Chapters 5 and 8).

In her well-known discussion of 'upward', 'downward' and 'central' conflation, Archer (1995) also unpacks some of these issues. As she reasons on the imitations of approaches that favour one side of this

${ }^{1}$ On the various implications and ramifications of this debate, see Mouzelis $(1974,1992)$ and Chernilo (2012c). 
dualism over the other, a key point for Archer is to reject the offers of recent approaches in social theory which, rather than emphasising one side in detriment of the other, suggest that the solution is to be found at that 'middle ground' or 'intersection' between structure and agency. Theories that thus emphasise the 'co-constitution' of structure and agency can claim to have transcended previous dichotomies but are instead found guilty of committing to a theoretical strategy that is unable to account for the emergence, i.e. the autonomy and causal efficaciousness, of agency, social structures and culture. Thus, individualist positions which are committed to upward conflation range from J. S. Mills's nineteenth-century utilitarianism to the rational choice theorists via modern 'scientific' psychology; collectivist standpoints that favour downward conflation are represented by a variety of writers that range from Rom Harré to Richard Rorty via Michael Foucault and several variants of structuralism and, finally, central conflationist include such figures as G. H. Mead, Anthony Giddens and Pierre Bourdieu. ${ }^{2}$

It is not my intention to revise here the various arguments and counterarguments on the structure and agency debate, but I should like to step back and revisit some of the reasons that make it such a central topic of discussion. For the purposes of the project of a philosophical sociology that is interested in looking at our preconceptions of the human, there are two arguments in Archer's work that have proved key. First, conflationist solutions are to be avoided because they by definition reject the autonomy of the human I am interrogating here. Second, behind all the work that has been done on theoretical critique, Archer contends, there is a main justification for the relevance of structure and agency in sociology that is not of conceptual nature: the sociological centrality of structure and agency is sustained by the fact that it is constitutive of the human condition itself. Structure and agency matter because this is a way in which sociology is able to capture one of the most fundamentally human way of experiencing life in society. Partly free, autonomous and enabled by structural circumstances, but also partly restricted, constrained and even conditioned by them, this tension mirrors the ways in which human beings themselves experience most aspects of their everyday lives. Thus, in the opening chapter of Realist Social Theory, Archer contends that this is a key phenomenological dimension of human existence and speaks of the undeniable 'authenticity' in 'the human experience that we are both free

${ }^{2}$ Archer's critique is available in (1988: $1-100$ and 2000: 17-117), while her positive argument on the morphogenetic cycle is possibly most clearly articulated in (1995: 65-92, 135-61). The secondary literature on this is extensive but see, for instance Archer et al. (1998) and Vandenberghe (2005). From a more critical perspective, see Depeltau (2008), King (1999) and Stones (2005). 
and constrained'; an experience, moreover, that derives 'from what we are as people and how we tacitly understand our social context' (1995: 29). In seeking to come to grips with this challenge, the sociologist has no immediate cognitive privilege over what lay members of society may be able to claim on how society works. What makes sociological explanations adequate is to be assessed not only by such scientific criteria as conceptual integrity and empirical purchase but also by the way in which they resonate with this ultimate ambivalence that makes up most of our human experiences. It is above all the ability to offer causal explanations that also makes sense to people that becomes the ultimate 'touchstone of adequate social theorizing' (1995: 29). The argument is in effect that the fundamental theoretical predicament of the sociologist is directly dependent on the fundamentally human experience of society:

The vexatious task of understanding the linkage between 'structure and agency' will always retain this centrality because it derives from what society intrinsically is. Nor is the problem confined to those explicitly studying society, for each human being is confronted by it every day of their social life ... such ambivalence in the daily experience of ordinary people is fully authentic. (1995: 1-2, my italics)

A similar argument is also introduced as one of the key conclusions to her following volume Being Human. Given that the focus in that book is precisely on unpacking a conception of agency, it is fitting that the argument is now explicitly introduced in terms that speak of a universalistic principle of humanity:

[T] hree of our major problems in social theory are in fact interrelated. These are the "problem of structure and agency", the "problem of subjectivism and objectivism", and the "problem of agency". All hinge, in various ways, upon the causal powers of people, their nature, emergence and efficacy ... it will only be the re-emergence of humanity, meaning that due acknowledgement is given to the properties and powers of real people forged in the real world, which overcomes the present poverty of social theory. (2000: 306, my italics)

This offer of an explicit articulation of a universalistic principle of humanity remains extremely rare in contemporary sociology and social theory (see, however, Chapter 8). Indeed, following our discussion on humanism in the Introduction, the argument can be made that it has taken sociology nearly half a century to re-engage with this problem. Archer is interested in making explicit a principle of humanity because this is a necessary step if we are going to succeed in raising the fundamental sociological questions about the relationships between structure and agency. A principle of humanity effectively makes social life possiblein her own formulation 'no people: no society' - and she also contends that our humanity remains autonomous from and is therefore irreducible 
to social and cultural forces. In turn, this has led her to explore, both empirically and theoretically, our human powers of reflexivity and internal conversation as they become the unique and specific contributions of our humanity to life in society $(2003,2007,2012)$. Building on Archer, we can say that an explicit argument about the human is an integral part of a sociological understanding of social life.

There will be two main arguments in this chapter. The first seeks to explain and then assess the reasons - theoretical, methodological and indeed normative - that led Archer to contend that the unpacking of a universalistic principle of humanity is a necessary task for sociological research. While this is not a task that sociology can fulfil on its own, she equally contends that understanding humanity's specific contribution to social life is not a marginal philosophical question that is to be added onto proper sociological enquiry; rather, it is integral to sociology itself. ${ }^{3}$ My second task shall be to explore in some detail what are the main substantive elements that define Archer's principle of humanity. Here, we will encounter such issues as a universal and continuous sense of self, human beings' pre-social powers whose actualisation is only efficacious in society, and our human relationships with the practical order. Her more recent work on reflexivity and the internal conversation shall then emerge as the leading dimensions that account for what is unique about human beings.

\section{I}

The full elaboration of a principle of humanity in Archer's work will make use of developments in various scientific disciplines and philosophical traditions - from qualitative interviews to neuroscience via, among others, Merleau-Ponty's phenomenology and Charles Pierce's pragmatism. But we can start with an argument that works mostly within sociology. In Realist Social Theory, one main reason she offers for this project is methodological: a universalistic principle of humanity is the condition of possibility of what is arguably one of the most traditional areas of sociological investigation: historical-comparative sociology. The need for a principle of humanity arises out of sociology's interest in 'understanding those of other times and places who live by other institutions'. Without such a sense of continuity in what makes us humans, Archer contends, the very possibility of keeping some 'thread of intelligibility' will simply fall

\footnotetext{
${ }^{3}$ Interestingly, John Rawls (1999b) makes a similar claim with regard to philosophy: in determining ideas of human nature, he says, philosophy needs both empirical psychology and social theory.
} 
apart (1995: 281). The argument is that the very possibility of understanding other historical and cultural contexts as historically and culturally different from our own depends on the fact that those who lived and experienced them are the same kind of beings as we are: humans who create cultural artefacts and then experience and handle them in the ways that only humans do. A different but related methodological argument is that a universalistic principle of humanity alone can provide us with stable and continuous parameters so that sociology can go out and explore cultural variability and social change: '[h]umanity, as a natural kind, defies transmutation into another and different kind. It is this which sustains the thread of intelligibility between people of different times and places, and without it the thread would break' (2000: 17).

In other words, the successful study of events in other times, places and cultural contexts is predicated on the fact that all members of the human species share some autonomous properties so that past, present and indeed future humans may develop a sense of transhistorical empathy that overrides, or rather underpins, their enormous sociocultural differences. ${ }^{4}$ Sociological research devotes its primary attention to those collectives we call social agents and actors, but the projects that they hold dear and the ways in which they go about carrying them out cannot be dissociated from implicit notions of humanity: on the contrary, they remain the 'a prioristic anchorage for the understanding of both ... The human being thus remains the alpha and omega of Agents and Actors (whose genesis can never lead to exodus from humankind)' (1995: 281). However thin and tentative, and regardless of whatever may get lost in the process, as social scientists we act as if human experiences can be understood, shared and then communicated. Our empirical propositions in the social sciences require us to presuppose that the subjects of our studies, and us researchers, share some attributes as part of the same species. We seek to understand experiences of change, variability and conflict by looking at the different ways in which social life can be organised. But we only recognise different social forms because we are able to trace them back to our shared human belonging: in any of the stories sociology tells, the subjects out there could well have been us. ${ }^{5}$

Up to now, this methodological justification for a principle of humanity has focused on the requirements of historical-comparative research. But an additional argument is now added; one that does not operate in the long-term coordinates of macro historical processes but on the much shorter time-span of an individual's biography. Archer contends that

\footnotetext{
${ }^{4}$ Arguably, it is this future empathy that becomes broken by posthumanists and transhumanists that emphasise discontinuity between a new generation of natural-born cyborgs and 'traditional' humans. See Introduction and Chapter 4.

${ }^{5}$ See a similar argument also in Chapter 2.
} 
any sense of personal identity and degree of continuity about experiencing my life as my own becomes impossible 'unless there is self-awareness that it is the same self who has interests upon which constraints and enablements impinge and that how they react today will affect what interests they will have tomorrow' (1995: 282). From such practical skills as swimming or roller-skating to the specifics of our professional roles, from learning how to speak a new language to our irrational allegiance to a particular football team, human action is built on this self who knows about its own past and is able to devise fallible projects for the future: 'processes like self and social monitoring, goal formation and articulation, or strategic reflection on means-ends relations ... are themselves dependent upon more primitive properties of person's (1995: 281). The sense of self we are talking about here is 'prior to, and primitive to, our sociality' (1995: 284). ${ }^{6}$ At this methodological level, then, the key argument is the need for an ultimate human grounding of all sociological explanations: 'the arguments presented here about what kinds of social beings people become are all anchored in the fact that it is human beings who do the becoming' (1995: 281). The social sciences operate within a strict immanent framework - human behaviour is to be explained exclusively by recourse to items that are themselves understandable by humans - and this notion is implicitly built on a universalistic principle of humanity.

But Archer's interest in the positive articulation of a universalistic principle of humanity does not end with the methodological quest for the production of social knowledge that can be used in various sociohistorical contexts. Indeed, a major insight of the realist tradition is that methodological arguments are neither self-contained nor do they stand in a substantive vacuum; rather, they are fundamentally intertwined with conceptual and ultimately ontological propositions (1995: 1-30). There is a specifically theoretical need for the positive determination of those substantive properties of human beings that allow for the creation of recreation of social life. Below we will comment on the role of human reflexivity in that context, but before we do so we need to discuss the fundamental philosophical underpinning of that argument on

\footnotetext{
${ }^{6}$ In more conventional sociological language, Archer argues that, while notions of 'roletaking' only require a rather thin conception of humanity, stronger notions of 'rolemaking' need a much more robust notion of it (2000: 314). See, similarly, Habermas's discussion of sociological theories of role in Chapter 5. As it will become apparent below, I reject Gronow's (2008: 45) argument that, by emphasising this autonomy of the human, Archer's notion of the self is 'undersocialised'. The key here is the distinction between self and person where the former is pre-social but the latter is not. See also Piiroinen (2014: 85-6) for an account of Archer's position on the autonomy of the human vis-à-vis society that nonetheless criticises her analytical dualism.
} 
reflexivity: human beings are emergent, i.e. independent, autonomous and causally efficacious, in relation to cultural and social forces.

Archer's argument here is that human beings possess uninterrupted consciousness so that a continuous 'sense of self' becomes 'the indispensable contribution which our humanity makes to our social life' (1995: 282). As she expands on this argument, Archer takes up Marcel Mauss's distinction between a concept of the self, which is socially construed and thus historically and culturally variable, and a sense of self that is pre-social and universal: all human beings in all cultures have a sense of 'I' (1995: 283). ${ }^{7}$ If this partial withdrawal of social conditioning sounds counterintuitive for a sociological audience, she contends that this results from the 'persistent tendency ... to absorb the sense into the concept, and thus to credit a human universal to the effects of culture' (2000: 125). This sense of self will require conceptual articulation but, as we shall also see below, its main feature is the fact that it is embodied and private rather than discursive and public (2000: 125). Indeed, her very idea of continuity of consciousness is predicated on the twin facts of our bodily constitution and its natural needs: 'the bodies of the members of the human species and the genetic characteristics of this "species being" [...] are necessarily presocial at any given point in time’ (1995: 286). The transhistorical character of these human properties speaks for their independence from society: they are of course exercised in pre-structured social and cultural contexts, but as properties they remain fundamentally independent from social life.

Because both arguments are fundamentally intertwined - bodily constitution and continuous sense of self - Archer can now pre-empt the charge of being found guilty of physicalist reductionism. The continuity of consciousness in a human body is central for the constitution of full personhood so that, although the body 'does not constitute the person, it defines who can be persons and also constrains what such people can do ... human beings must have a particular physical constitution for them to be consistently socially influenced' (1995: 287-8). In other words, our ability to have concepts of the self and of the social is already dependent upon the fact that we are 'the kind of (human) being who can master social concepts ... the distinguishing of social objects cannot be a predicate but only a derivative of a general human capacity to make distinctions' (1995: 286). However central social life is in the ultimate actualisation of our human potentials, society is neither the only source of these potentials nor the only domain with which humans interact:

${ }^{7}$ In Being Human, Archer again cites Mauss approvingly: 'there has never been a human being who has not been aware, not only of his body but also of his individuality, both spiritual and physical' (Mauss, cited in Archer 2000: 109; see also 87, 97). 
it is precisely because of our interaction with the natural, practical and transcendental orders that humanity has prior, autonomous and efficacious powers which it brings to society itself - and which intertwine with those properties of society which make us social beings, without which, it is true, we would certainly not be recognisably human. (Archer 2000: 17-18) ${ }^{8}$

At this conceptual level, Archer's understanding of the human has so far included continuity of consciousness and bodily constitution as core to the human ability to distinguish and interact with different orders of reality (more on this below). The final dimension that needs to be mentioned also connects the pre-social features of homo sapiens as a unique species with the fact that these potentials are fundamentally (though never exclusively) realised in society. Archer describes it as the ability to imagine new social forms:

homo sapiens has an imagination which can succeed in over-reaching their animal status ... human beings have the unique potential to conceive of new social forms. Because of this, society can never be held to shape them entirely since the very shaping of society itself is due to them being the kind of beings who can envisage their own social forms. (1995: 289)

Archer's formulation of the principle of humanity comes to completion, then, as she includes the ability to imagine and devise new social forms. This is a critical agential mechanism of social change, what she refers to as morphogenesis, because new social situations also change the conditions within which autonomous human powers are to be exercised. This is the basis for the key process of dual morphogenesis: it is not only the fact that agents can (imperfectly and only to a degree) modify social structures but that agents themselves change as part of that same morphogenetic process (2000: 258-67, 283-7).

If this is the case, we can now unpack the normative consequences that are built into these conceptual and methodological arguments for a universalistic principle of humanity. This is of course not new; it has been my contention throughout this book that a universalistic principle of humanity is not only a cognitive requirement for sociology to work but that it also has normative implications. To be sure, whether and how we decide to unpack these, and then integrate them into our social scientific work, is an open question that can only be answered by practitioners themselves. Depending on how social scientists understand their tasks

\footnotetext{
${ }^{8}$ Not for the first time in this book, we encounter the fact that references to the transcendental raise questions of their own kind (see Chapters 3, 4 and 6). In Realist Social Theory, Archer accepted that 'the transcendental as an autonomous field is not open to selfverification' but the point that remains key for her argument on a principle of humanity is 'the possibility of authentic inner experience' (1995: 291-2).
} 
as social scientists, they may or may not seek to spell out the normative consequences of their work. But this does not change the fact that, to the extent that social scientific propositions operate within an implicit principle of humanity, there are normative implications that do follow from our conceptual and methodological commitments: these planes need to be clearly distinguished but we cannot, I contend, fully or definitively separate them out. Even if we decide not to engage with them, there are normative implications that simply do not go away. Archer does spell out the normative implications of her methodological and conceptual commitments and, given that she seeks to establish the autonomy of humanity vis-à-vis society, this normative dimension is an integral part of her sociological programme:

since it is our membership of human species which endows us with various potentials, whose development is indeed socially contingent, it is therefore their very pre-existence which allows us to judge whether social conditions are dehumanizing or not. Without this reference point in basic human needs ... then justification could be found for any and all political arrangements, including ones which place some groups beyond the pale of "humanity". Instead, what is distinctively human about our potentialities impose certain constraints on what we can become in society, that is, without detriment to our personhood. (1995: 288-9, my italics)

The task of promoting or indeed working politically towards the realisation of institutions that favour this type principle is not one that is only or indeed specifically incumbent on the sociologist on her expert role: its appeal surely falls outside of what defines the practices of the social scientist as a social scientist. And yet the argument that I am making through Archer's reflections is that there are direct normative implications of carrying out sociological work. On the grounds of its universalistic principle of humanity, sociology $i s$ in a position to explain the rise of various social institutions and then unpack its humanising or dehumanising effects on the development of integral human personhood. The normative grounds on which judgements are being made depend directly on whether or not the pre-social contributions of our shared humanity to social life are being protected, promoted, affected or irreparably damaged. ${ }^{9}$

Archer rehearses a similar argument in different ways, but one that is particularly illustrative focuses on the consequences of withdrawing all autonomy to humanity and conceiving it instead as a gift of society. The main problem with this position, which is shared by a wide range of

9 This explains, it seems to me, that a prevailing normative sensibility in the critical realist literature emphasises eudemonistic ideas of 'human flourishing' where some notion of human potentials is being empowered or constrained by society. See, for instance, Sayer (2011). 
sociological imperialists, postmodernists and indeed social constructionists, is that it leaves us with no solid ground on which to defend or criticise different social institutions: ' $[t]$ here can be no inalienable rights to human status where humanity is held to be a derivative social gift' (2000: 124). This is not altogether different from the argument that, in the Introduction, I raised against some versions of posthumanism: they cannot develop a critical theory that cares deeply about social injustices but then makes that caring creature fully dependent on society itself: 'if resistance is to have a locus, then it needs to be predicated upon a self which has been violated, knows it and can do something about it' (2000: 32). In a formulation that may partly resonate with those of Boltanski in Chapter 8, the consequences of being unable to capture conceptually the autonomy of our humanity vis-à-vis sociality may be felt most clearly at a normative level; that is, it is expressed in the ways we justify the obligations towards those who, for whatever reason, are in weaker or more vulnerable positions in society:

there is something very worrying about a social approach to personhood which serves to withhold the title until later in life by making it dependent upon the acquisition of social skills. This fundamentally throws into question our moral obligations towards those who never achieve speech (or lose it) or who can never relate socially, because, having failed to qualify as persons, what precludes the presumption that they lack consciousness of how they are treated (thus justifying the nullification of our obligations towards them)? (1995: 291)

Archer's universalistic principle of humanity works as the key counterfactual that makes possible our understanding of life in society: social life presupposes the fundamental equality of human beings, who are all equally equipped for the creation and recreation of social life. It is this fundamental equality that gives normative purchase to the claim that it matters so much that we do not choose, nor can we alter at will, the highly unequal social conditions under which we exercise our human capabilities. But for this argument to work, it remains central that we see how this universalistic orientation works simultaneously in three planes: conceptually, all human beings are equally able to create and recreate social life; methodologically, social scientific knowledge is susceptible of translation across different cultural and historical contexts, and; normatively, we are able to assess different social and institutional practices as either favouring or undermining those fundamental qualities that are constitutive of our shared humanity. The principle of humanity is the condition of possibility of sociological knowledge - it is sociology's own regulative idea (Chernilo 2007a). 


\section{II}

Archer's opening claim in Being Human is precisely the defensive statement that we ought to 'reclaim Humanity which is indeed at risk' (2000: 2). Building on her critique of upward, downward and central conflation, a primary goal of that project was to resist equally wholly individualistic definitions that reduce our humanity to hedonistic motives and constructivist positions that define humanity exclusively through our symbolic interactions with the social world. Her positive starting point is, as we have seen, the claim on the bodily grounding of our continuous sense of self as this offers a pre-social justification for the autonomy of our humanity. We also briefly mentioned that she sees humans as living in a world that is differentiated in three main orders: the natural, the practical and the social orders. If we now briefly explain each one of them, we see that our physical well-being depends on our relationships with the natural order; our performative achievements depend on our mastery of objects in the practical order and our notions of self-worth are constituted through interactions in the social order (2000: 9) ${ }^{10}$ Archer contends that, as humans, we require all three orders and, crucially, that there is no automatic or necessary harmony in the ways in which we interact with them. The predicament of the human condition requires us to pay attention to all orders simultaneously, to realise that there is continuous intercommunication between them, but also to accept that there can be no guarantee that they shall 'dovetail harmoniously' (2000: 220). The notion of modus vivendi on which our personal identity coheres refers to our simultaneous yet complicated relationships with all three orders. ${ }^{11}$

In relation to the natural world, the key human challenge lies of course in our physical adaptation to it, which includes also our human attempts at its modification. Archer connects this dimension to Marx's critical insight of the human need for 'continuous practical activity in a material world' (2000: 122). ${ }^{12}$ Crucially, the partial independence between human powers and social structures is another expression of the fact that meeting our physical and organic requirements in our relations with the natural world may well depend on society's institutions but is not something for society alone: physical 'survival cannot delay practical

10 The notion of recognition as self-worth has of course been reintegrated into critical social theory by Axel Honneth (2005).

${ }^{11}$ As part of her critique of Bourdieu, Archer contends that he does not allow for continuity or possible translation between these orders because they are all subordinated to an economic logic of capitals (2000: 179-80). We will come back to this below.

12 As we saw in Chapter 3, this is also key to Parsons's understanding of the function of adaptation as part of the paradigm of the human condition. See also Archer (2000: 133). 
action in the environment until the linguistic concept of the self (as "I") has been acquired' (2000: 123).

The second domain of practice is in fact the central in Archer's argument. Here, the primary dimension is that of our interactions with objects that then constitute the platform for our performative achievements. Thus understood, practice is primarily non-discursive and, even more importantly, she contends that practice has 'primacy' and is indeed 'pivotal to all our knowledge' (2000: 152). As members of the human species, practical accomplishments in our relations with objects and non-human creatures are the ones that fundamentally shape who we become: 'our human relations with things (animate and inanimate, natural and artificial), help us to make us what we are as persons' (2000: 161). In this domain, moreover, our human uniqueness vis-à-vis animals remains more a matter of degree than of quality, and this includes also 'our tendency to enhance or extend our embodied knowledge by the invention and use of artefacts' (2000: 161). Not only that, the critical dimension that humans share with animals is that of being able to anticipate the impact that external facts may have on our bodies (2000: 202). One of Archer's most fundamental arguments is also found here, as she contends that these accomplishments in the practical order are intrinsically nonlinguistic' (2000: 160). Recurrent usage of such expressions as the need to develop 'a feel for the game' is, in her view, a way of accepting the fact that practical accomplishments cannot be 'easily or fully expressed in words' (2000: 160). Practical consciousness and above all performative accomplishments in our bodily relationships with the elements (swimming in the case of water, jumping in the case of gravitational pull), with objects (aptly using a sharp knife, driving a car at speed) and with nonhuman beings (our relationships with animals and indeed technology) all fall within this category. The fact that most of them can only be performed within a wholly social setting does not for her alter the fact that these are non-discursive practices and accomplishments: 'practical consciousness represents that inarticulate but fundamental attunement to things, which is our being-in-the-world' (2000: 132). To affirm the primacy of practice over language is another argument against the notion that the latter offers an adequate definition of the human. In turn, this offers additional grounds to her rejection of the conventional proposition that, in modern science, epistemology is prior to ontology. Archer reverses this relationship precisely on the grounds of the primacy of practice over the social bonds of language:

the argument that "practice is pivotal" has, as its basic implication, that what is central to human beings are not "meanings" but "doings" ... it is in and through 
practice that many of our human potentia are realised, potentials whose realisation are themselves indispensable to the subsequent emergence of those "higher" strata, the individual with strict personal identity ... it has been argued here that a human being who is capable of hermeneutics has first to learn a good deal about himself, about the world, and about the relations between them, all of which is accomplished through praxis. In short, the human being is both logically and ontologically prior to the social being, whose subsequent properties and powers need to be built upon human ones. (2000: 189-90)

Archer's argument on the final domain, the social world, includes human interactions between people, people's ability to create and interpret various cultural artefacts, and the results of aggregated action that give rise to social agents and actors (1995: 247-93; 2012: 173). It is on this basis that Archer makes the case that our personal identity is wider than our strictly social identity, on the one hand, and that the positions we occupy as social actors involve an active commitment to the achievement of certain goals, on the other. This kind of active interest is lacking in the more passive social positions we occupy as agents (2000: 253-4). ${ }^{13}$

Although they are never mentioned explicitly, we recognise here some of the foundational themes of early philosophical anthropology; crucially, the notion that the human body is both a physical presence in the world and the condition of possibility of our experiencing the world: '[o]bjects are before me in the world, but the body is constantly with me, and it is my self-manipulation, through mobility and change of point of view, which can disclose more of the object world to me' (2000: 130). The natural and the practical orders are therefore both fundamentally related to the bodily constitution of our humanity: the satisfaction of our needs, on the one hand, and our mastery of various subject/object relations, on the other. These two may of course overlap, but need to be distinguished. This is again an argument in support of the claim that our ability to treat other humans as members of our species, and then understand social facts as ultimately the result of human interaction, is already built into our shared humanity: 'our practical work in the world does not and cannot await social instruction, but depends upon a learning process through which the continuous sense of self emerges' (2000: 122). Human fundamentals such as the intuitive grasp of causal action and the basic laws of logic are dependent upon this same universal sense of embodiment: '[t]he basic

${ }^{13}$ One additional argument is the need to uphold an analytical dualism between social interactions that lead to the creation of a particular cultural product (the composition of an opera) and the emergent, cultural properties of the opera itself, whose autonomous existence does not need social actualisation in the present (1988: 1-21). This also resembles Parsons's distinction between the fiduciary system (churches and schools as social institutions interested in symbolic and cultural reproduction) and the cultural system proper that refers to values and meanings in their own right. 
laws of logic are learned through relations with natural objects: they cannot be taught in social relations, since the linguistic medium of socialisation presupposes them' (2000: 126, my italics). The fundamental distinction between social and non-social objects is in itself one contribution of our humanity to society:

Each one of us has to follow the same personal trajectory of discovering, through private practice and by virtue of our common human embodiment, the distinction between self and otherness and then that between subject and object, before finally arriving at the distinction between the self and other people - which only then can begin to be expressed in language. These discoveries are made by each and every human being and their disclosure is independent of our sociality: on the contrary, our becoming social beings depends upon these discoveries having been made. (2000: 136$, my italics $)^{14}$

Archer is advancing what she calls a 'stratified view of humanity', where the different strata are emergent and irreducible to one another. Thus seen, she says, it is not only that social structures, culture and humans are strata, but human beings themselves are 'constituted by a variety of strata ... schematically, mind is emergent from neurological matter, consciousness from mind, selfhood from consciousness, personal identity from selfhood, and social agency from personal identity' (2000: 87). For our purposes, there are four main strata that matter the most: self, person, agent and actor. The argument again reinforces her proposition that an idea of the self is the key dimensions of our humanity that remain presocial: '[a]s adult human beings, we are three-in-one - persons, agents and actors - but we never lose our genesis in the continuous sense of self which is formed non-discursively through our practical action in the world' (2000: 153). Personal identity is complete in adulthood because only then have people developed a fuller and more stable set of relations with the three orders of reality we have discussed so far: the natural, the practical, and the social. It thus follows that these will determine where our 'ultimate concerns lay and how others were to be accommodated to them' (2000: 257). The emergence of full personal identity is a social accomplishment in a way that our sense of self is not. Yet because it entails the simultaneous incorporation of the three orders, personal identity remains wider and deeper than any notion of social identity: '[S]ocial identity is only assumed in society: personal identity regulates the subject's relations with reality as a whole. Therefore, of the two emergent human properties, the self stands as the alpha of social life, whilst the person is its omega' (2000: 257). Agents and actors are then exclusively social in

${ }^{14}$ Indeed, the very distinction between self and other derives 'from our embodiment in the world' (2000: 129). 
a way that the self and the person are not and, because of that, agents and actors are themselves dependent on self and personhood. Agents and actors are collective instantiations of our humanity, but their main difference is that the former connotes the passive position people occupy in society (gender, age, nationality, for instance), whereas the latter involves active engagement and setting of goals to be achieved (we are students, football fans, union members, etc.).

A major theoretical implication is to be drawn from our discussion thus far: for all her concerns with what is specific about our humanity, Archer's argument is explicitly built as a critique of anthropocentrism. Let me unpack this argument in the following three steps:

1. The human reliance on the body for the realm of practice brings us closer to rather than further away from animals: this basic domain of human experience is not specifically human and thus allows the whole argument to take a critical distance from anthropocentrism. As we saw already, animal species cannot enhance their experience through the use of tools to the extent that humans do, but this is ultimately a matter of degree (2000: 111).

2. Ontogenetically, we have seen that the ability to distinguish the social world as an autonomous domain, and to manipulate social objects within it, is not concomitant with birth; it instead only appears in early childhood. As we learn, for instance, that the laws of nature apply in general and are not subject to our control, we also learn that an adequate understanding of the social world equally implies the rejection of an anthropocentric outlook: neither everything that occurs in society centres on my needs, desires and feelings nor can I fully control the actions of others. This, Archer calls the very 'foundations of nonanthropocentric thought' (2000: 146). She expands on it as follows:

it is only as embodied human beings that we experience the world and ourselves ... and thus can never be set apart from the way the world is and the way we are ... Those who only accentuate $u$ in our necessarily limited, because embodied, nature then endorse anthropocentrism - a world made in our image and thus bounded by our human limitations, as in pragmatism or critical empiricism .... Yet, the affordances of human experience describe our point of contact with reality; but they neither exhaust reality itself, nor what can be discovered about it. Our "Copernican" discoveries exceed and often run counter to the information supplied by our embodied senses. (2000: 145) ${ }^{15}$

3. Through its critique of both religion and traditional metaphysics, the modern scientific and philosophical imagination gives a new lease of

${ }^{15}$ We touched on this Copernican turn in Chapter 1 on the basis of Gaston Bachelard's notion of epistemological obstacle and will come back to it in the Epilogue. 
life to an anthropocentric perspective: anthropocentrism reappears 'with a vengeance' when humans replace god in its self-determining and apparently omniscient powers (2000: 21-3). Archer then contends that little has in fact been gained here because what started as a critique of foundationalism ends up in an unacceptable kind of perspectivism: it all depends on how humans claim things to be (2000: 45). The 'charitable humanism' that underpins this position is mistaken because what the world is does not depend on how humans think it to be (2000: 21). ${ }^{16}$ An additional normative consequence of this inflated anthropocentrism is that it creates the condition for social constructionism and its view that humanity is a social product and it is, above all, linguistically formed. As we have seen, Archer rejects any anthropology that builds on the idea of homo significans because no autonomous idea of humanity can be built on its premises. (2000: 24-5)

Archer's rejection of anthropocentrism then offers two different lines of argument. In the first, her ideas on the importance of the natural and practical orders are referred back to the development of the natural sciences in the modern world. It is true that modern science affords humans with a sense of wonder about our own omnipotence - we can play god if we so wish - but the more salient implication in her view is that, because human life depends on domains that it neither produces nor fully controls, the scientific imagination remains, first and foremost, a rejection of any strong anthropocentrism. ${ }^{17}$ The second argument against anthropocentrism also goes back to the ontological fallacy of mistaking our representations of the world for what the world actually is: '[c] onflating worth with being can only result in anthropocentrism because it elevates our epistemic judgements over the ontological worth of their objects' (2000: 225). Archer's realism is a critique of anthropocentrism because the latter, instead of actually helping in making a persuasive claim on the fact that 'people matter', ultimately depends on the 'strident doctrine that nothing matters at all except in so far as it matters to man' (2000: 23). In its ultimate subjectivism, we may even say that nothing matters at all unless it matters to me. The wider implications of her critique are worth looking at in detail. In Archer's own words:

${ }^{16}$ See also the discussion of Sartre's subjectivism in Chapter 1 and Jonas's critique of anthropocentrism in Chapter 4 .

${ }^{17}$ Incidentally, this may be one reason that explains why scientists find it difficult to understand people's ethical concerns with the results of research: there is a sense of entitlement that follows, in their view, from their ability to 'do' things. This practical applicability then overrides possible concerns with the ethical implications of what they do. 
Anthropocentrism binds us intransigently to indexicals even though it wants these to be as big as the human race. But often it is not the case that humanity shares a universal language which is accepted as necessary in order to make sense of experience, and even if we do we might be wrong because the game we are playing might be that of global actualism. Thus knowledge from a universal human perspective may only represent globalised fallibility. After all this is what Enlightenment thinkers held the pervasive religious language of the antecedent period to be: it is also how postmodernism reflects upon the generalisation of the Enlightenment project itself in the language of Modernity. (2000: 49)

While I follow Archer in her commitment to the universalistic underpinnings of a principle of humanity, I take a more positive stance towards the possibilities that are opened by this 'global actualism': this is precisely what current globalisation processes open up with the possibilities of a more cosmopolitan outlook (Chernilo 2012b). Here, however, it is important to make it clear that this is not to do with possible Eurocentric implications or presuppositions of her argument. ${ }^{18}$ In fact, Archer (1991) had early on made a convincing programmatic statement on these questions in the context of her presidential address to the International Sociological Association. On the one hand, and this is a statement whose strictly empirical validity is surely a matter of contention, she has recently argued that the conditions of accelerated social change that she described as the rise of the morphogenetic society have not fully reached 'the south' (2012: 17). The argument is plausible, it seems to me, if it means that there are pockets of people who feel the effects but are not in a position to actively engage with the contemporary conditions of global modernity: otherwise, in terms of the sheer number of people being affected by globalisation, poorer parts of the world have arguably witnessed more rather than less changes than wealthier regions. More importantly, on the other hand, Archer herself had offered a more nuanced account of the relationships between a universalistic principle of humanity and current global modernity: '[f] or the first time ever, there are pressures upon everyone to become increasingly reflexive, to deliberate about themselves in relation to their circumstances; not freely, because unequal resource distribution, life chances and access to information have intensified dramatically on a world scale, but nevertheless self-consciously, given the demise of collective agencies shouldering the burden for them' (2007: 53).

We need to ask, however, whether the strong rejection of anthropocentrism that has been put forward - as condition of possibility of our practical occupancy in the world - comes with a concession to a soft version of it: human embodiment as a restriction to the ability of self-transcendence that

${ }^{18}$ Her rejection of Eurocentrism is also explicitly articulated in her preface to the Spanish edition of Realist Social Theory (Archer 2009). 
we discussed in Chapter 2. To a large extent, some of the main themes in the posthumanist literature depend on some version of this argument: humanism and anthropocentricism are built on the pretence that humans can never step outside their embodiment. But this is a chain of thought that Archer explicitly rejects because for posthumanists human embodiment is all that there is. The more pressing question then becomes whether we are able to use this embodiment as a resource that also works towards its transcendence. Archer's argument on human reflexivity, it seems to me, allows her precisely to do this.

\section{III}

The proposition that reflexivity defines how humans exercise their autonomous powers in society was first introduced in Being Human; for instance in reference to Marcel Mauss's argument on the concept of the self. More recently, in The Reflexive Imperative in Late Modernity, Archer looks back at this initial interest in reflexivity as something that was not intrinsically related to the study of 'human subjectivity', but which rather 'began from seeking to answer the theoretical question about how structure and culture got in our personal acts' (2012: 294). Understanding reflexivity has then to do with the delimitation of those defining powers of agency that are irreducible to cultural and structural properties. Thus conceived, reflexivity becomes 'a personal property of human subjects, which is prior to, relatively autonomous from and possesses causal efficacy in relation to structural or cultural properties ... "reflexivity" is put forward as the answer to how "the causal power of social forms is mediated through human agency"' (2007: 15).

Self-sufficient, autonomous and causally efficacious, reflexivity is expressed in our internal conversations: '[r] eflexivity is exercised through people holding internal conversations' (2007: 63). Reflexivity is fundamentally exploratory and transforms, reorients and prioritises our personal concerns into the projects that we seek to realise in society. Reflexivity usually adopts the form of question and answers that take place inside our heads and, because it is oriented to objects (including our own physical embodiment) it has a fundamentally practical intent: 'reflexivity is the regular exercise of the mental ability, shared by all normal people, to consider themselves in relation to their (social) contexts and vice versa' (2007: 4). Reflexivity is internal but refers to things that take place in the world; only external objects and events can trigger the autonomous exercise of human reflexivity. This connection with the world also allows Archer to contend that the internal conversation is not a form of solipsism or mere introspection: 'human interaction with the world constitutes the 
transcendental condition of human development' (2000: 17; see also 2000: 315 ; 2012: 11). Language plays a major role in the way this is actually achieved as language becomes the interface between 'the inner' and 'the outer':

the private and innovative use made of the public linguistic medium is just as significant as the fact that natural language is an indispensable tool for the emergence of the private inner world in the first place. As the home of the internal conversation, the inner world is a domain of privacy fabricated from public materials; as a "plastic theatre" of inner drama, it is dependent upon my imaginative construction and use and is thus a first-person world; as the bearer of causal powers, its exercise can modify both us ourselves and our social environment. (2007: 70)

For reflexivity to be treated as a genuine emergent property, it can be determined by neither our personality structure nor social class (2012: 16; 2007: 96-7). If not an idea of human nature as such, Archer accepts that at stake here is the definition of our major anthropological markers as a species: reflexivity is to be found throughout all human cultures (2012: 2) and she goes as far as to define it the 'transcendental condition of the possibility of any society and one for which empirical evidence can be adduced' (2007: 29). Equally importantly, from the point of view of its practical purchase for social research, Archer contends that our human abilities and skills work through the medium of reflexivity: it is through the practical deployment of various kinds of reflexivity that humans make their way through the world. Reflexivity matters because none of the big 'questions about the nature of human action in society is answerable without serious reference being made to people's reflexivity ... Human beings are distinctive not as the bearer of projects, which is a characteristic people share with every animal, but because of their reflexive ability to design (and redesign) many of the projects they pursue' (2007: 5 and 7, my italics).

Sociologists have so far not paid enough attention to the workings of reflexivity and yet, when they have, they mistake it for a property of social systems. Sociology, Archer contends, has failed to give an account of one of the most fundamental mechanisms through which life in society takes place: 'no reflexivity: no society' $(2007: 15 ; 2012: 2)$. In the case of contemporary sociology, the two main writers against which she makes this case of the neglect of reflexivity are Pierre Bourdieu and Ulrich Beck. In relation to Bourdieu, Archer argues that the idea of habitus is a paradigmatic case of central conflation; that is, structure and agency are elided rather than remain analytically distinct. At the same time, as habitus emphasises our pre-conscious and habitual routines of action, it remains fundamentally at odds with the ability of people to take control over their 
own actions. This static feature of habitus makes Bourdieu unable to explain social change and this goes against the general morphogenetic impetus of Archer's work (2007: 38-55). ${ }^{19}$ In relation to Beck, Archer accepts his thesis that there is a decline in traditional actions and routines but she then criticises him on two different grounds. First, because Beck sees reflexivity only as a societal process rather than as the property of agents; even Beck's notion of individualisation is something that occurs, to a large extent, at the back of individuals themselves. Second, Archer's reflexivity involves the reconfiguration rather than the weakening of social structures (2007: 3-4, 29-37, 55). Increasingly, however, reflexivity has become itself an epochal diagnosis in Archer's work. Modern societies as such are marked by contextual discontinuity; structural changes and lack of synchronicity between structural and cultural transformations make for enhanced reflexivity a key marker of modernity itself (2012: 23-6). What we witness over the past three or so decades is, therefore, that 'the extensiveness with which reflexivity is practised by social subjects increases proportionate to the degree to which both structural and cultural morphogenesis (as opposed to morphostasis) impinge upon them' (2012: 7). As we see in Table 7.1, in contexts of accelerated social change autonomous reflexivity becomes the most distinctive one in global modernity. The key fact that social scientists are missing here is that human reflexivity is not applied homogeneously throughout society. There is no one single way of being reflexive but, on the contrary, different modes 'that are differently dependent upon internal conversation being shared in external conversation' (2007: 84). Archer develops a fourfold typology of communicative, autonomous, meta- and fractured reflexivity, which obtains from the qualitative and quantitative empirical studies that make up the bulk of her writing of the past fifteen years (2003, 2007, 2012).

This differentiated exercise of reflexivity matters because it is constitutive of who we are as unique individuals. Moreover, while human relations to the natural and the practical environments may not be primarily reflexive, their continuation as a project, as a concern whose accomplishment matters to us, is informed by socially mediated reflexivity. ${ }^{20}$

19 Dave Elder-Vass (2007) has made a strong case for the convergence of both projects, but Archer has remained unmoved: even if the 'reconciliation' between their approaches may be 'formally feasible', she contends, that it still remains 'empty in practice' (2012: 76). The key point for me, as explained in the Introduction, is the reductionist anthropology that underpins Bourdieu's sociology.

${ }^{20}$ In reference to the classical Turing imitation game, Archer formulates this argument thus: 'Even if some invented a mind-reading machine, they would be unable to understand another's inner dialogue, without having access to that person's whole life, and thus their code, and hence becoming another "him"' (2007: 80). 
Table 7.1 Reflexivity, social mobility and the internal conversation

\begin{tabular}{|c|c|c|c|c|}
\hline Mode of reflexivity & Type of internal conversation & $\begin{array}{l}\text { Prevalent form of social } \\
\text { mobility }\end{array}$ & $\begin{array}{l}\text { Relation to natal context (e.g. } \\
\text { home friends) }\end{array}$ & $\begin{array}{l}\text { Relation to new contexts } \\
\text { (e.g. new friends) }\end{array}$ \\
\hline Communicative & $\begin{array}{l}\text { To be confirmed and } \\
\text { completed by others before it } \\
\text { can lead to action }\end{array}$ & $\begin{array}{l}\text { Social immobility or } \\
\text { downward social mobility. } \\
\text { People remain close to } \\
\text { natal contexts }\end{array}$ & $\begin{array}{l}\text { Retention. There is contextual } \\
\text { continuity and prevalence of } \\
\text { social conformity }\end{array}$ & Created commonalities \\
\hline Autonomous & $\begin{array}{l}\text { Self-contained and leading } \\
\text { directly to action }\end{array}$ & Upward social mobility & $\begin{array}{l}\text { Selection. Contextual } \\
\text { discontinuity. Instrumental } \\
\text { rationality and personal } \\
\text { success reproduce social } \\
\text { structures }\end{array}$ & Interest-based \\
\hline Meta & $\begin{array}{l}\text { Critical evaluation of previous } \\
\text { inner dialogues. They are } \\
\text { also critical about society }\end{array}$ & $\begin{array}{l}\text { Costs of downward social } \\
\text { mobility are expected and } \\
\text { regarded as acceptable }\end{array}$ & $\begin{array}{l}\text { Rejection and social volatility. } \\
\text { Value-rationality and social } \\
\text { concerns favour social change }\end{array}$ & Value-based \\
\hline Fractured & $\begin{array}{l}\text { Cannot lead to purposeful } \\
\text { courses of action. Intensifies } \\
\text { distress and disorientation }\end{array}$ & Undetermined & Absence & Dependency \\
\hline
\end{tabular}

Source: Personal elaboration based on (2007: 93-9; 2012: 13, 148). See also Caetano (2015) for further discussion. 
As elaborate commentary, emotions fundamentally regulate our relations with the world (2000: 204). Archer then expands on the idea of emotions in order to emphasise how humans relate to the the social, the practical and the social worlds. It is thanks to the internal conversation that 'our first-order emotionality is reflexively transformed into second-order emotional commentary' (2000: 221). As we mentioned them above, the key emotion for the natural world is that of physical well-being, for the practical order it refers to such experiences of frustration, boredom, satisfaction or even euphoria in the ways we accomplish things and, with regard to society, self-worth is our prime concern (2000: 212-15). If emotions have traditionally been seen as irrational, this is not because of some intrinsic feature that precludes them from systematic consideration but because they refer to things that concern us deeply: emotions are linguistically articulated and passionate accounts about what is going on in the world - and, to that extent, they are anthropocentric. But because we are fallible beings, this same anthropocentrism may backfire and become wholly counter-functional (2000: 207-8). Emotions refer to all domains of reality, so Archer rejects the idea that there is any such thing as a basic emotion: emotions come in clusters that require prioritisation and this is an active task that is only performed by humans themselves through their internal conversations (2000: 199-200).

Because it is conceptualised as independent vis-à-vis social and cultural structures, it is not always clear whether reflexivity applies only to human relationships to the social world or, instead, it applies also to human interactions with the natural and practical world. If the former, the argument emphasises the fact that no form of human activity takes place wholly outside a social environment: culture and society are the artificial environment that surrounds everything human. If the latter, however, the argument would have to be that even those activities that deal, for instance, with organic adaptation (breathing) may become the object of reflexive monitoring whether or not they have primary social causes (catching a cold). Our actions to change that organic state are indeed social (visiting a doctor, taking medicine, etc.) but need to have an adequate correlate with the intransitive properties of nature herself. Archer argues that emotions work through commentary about our concerns in the internal conversation and also that reflexivity refers primarily, indeed almost exclusively, to our relations with the social world. The methodological purchase of both arguments is clear, as it allows for greater precision in looking at emotions and reflexivity in a manner that is susceptible of empirical sociological research. This move appears to create complications for her argument on the autonomy and emergence of our humanity vis-àvis society, however: if emotions are to be seen, fundamentally, as linguistic 
articulations of our concerns, then we can hardly have emotions that have not gone through some form of social shaping. Similarly, if reflexivity refers primarily to our concerns in the social world, then it is not clear how or why can reflexivity remain immune from social influences throughout one's life and does not become derivative, say, from class socialisation or liminal experiences of success or failure. This matters because at stake here is the claim that reflexivity is the defining anthropological features of an autonomous idea of the human.

Archer's idea of ultimate concerns is another way of advancing a critique of utilitarianism and instrumental rationality as the only or at least major drive of individual psychology (Archer and Tritter 2000). Rather than being primarily selfish, hedonistic or self-centred, humans have, on the contrary, a fundamental 'capacity to transcend instrumental rationality and to have "ultimate concerns"" (2000: 4). And it is through this focus on ultimate concerns that she elaborates further the positive content of her anthropology in terms of a substantive definition of what makes us human beings: 'we are who we are because of what we care about: in delineating our ultimate concerns and accommodating our subordinate ones, we also define ourselves' (2000: 10). For emotions to emerge, we have to care about the evaluations that are at stake: '[i]t is we human beings who determine our priorities and define our personal identities in terms of what we care about. Therefore we are quintessentially evaluative beings ... the natural attitude of being human in the world is fundamentally evaluative' (2000: $318-19)$. A human is a being who cares. ${ }^{21}$

There is indeed a resemblance here to some of the ideas we discussed in Chapter 6 on Charles Taylor's conception of strong evaluations and moral goods. Taylor's argument on 'transvaluation' is of relevance to Archer because it makes clear that emotional complexity is in fact normal occurrence: we learn to deal with a constellation of emotions that only become apparent through our internally running commentaries: emotions are plural because ultimate concerns are themselves plural (2000: 226). Prioritisation and then accommodation of concerns gives rise to one's modus vivendi that is, again, personal. This is what the internal conversation does: 'the goal of defining and ordering our concerns, through what is effectively a life-long internal conversation, is to arrive at a satisfying and sustainable modus vivendi' (2007: 87). But at the same time that she offers a similar argument to Taylor's, Archer is too much of a sociologist to accept the normativism of Taylor's position. She then speaks of relational

${ }^{21}$ See also: 'people have ultimate concerns which are expressive of who they are, and therefore not a means to some further end' (2000: 83, underlining mine). 
goods and relational evils in a way that directly contravenes Taylor's insistence on our attachment to the good: people engage in harmful and indeed self-destructive behaviour that becomes constitutive to what they are - there is not automatic association between self and good (2012: 99, 257-8). ${ }^{22}$ A personal modus vivendi does offer a sense of unity and, to that extent at least, it may operate as the kind of hypergood that Taylor rejects although in this case this is a practical accomplishment of people themselves rather than the imposition of professional philosophers. It is the fact that we become able to deal with the various and simultaneous challenges of life in a way that is satisfactory for us that constitutes the condition of possibility of the good life. This is, to be sure, too weak a normative argument for Taylor, for whom ultimate concerns are necessarily high and lofty rather than, say, looking after one's allotment. ${ }^{23}$

Archer sides with Taylor against the Kantian notion that proceduralism is the right approach to deal with normative questions. Modern proceduralism fails because it presupposes two notions that she rejects: first, that there is a unity or at least clearly a hierarchy of goods that can be univocally preferred and be turned into a meta-rule; second, sound moral reasoning is not dispassionate but emotional in relation to things we care deeply about (2012:112-13). I have already argued that I give greater importance to moral proceduralism as a way of trying to make sense about the complexities of social life. Archer is surely right when she says that we experience conflicts among our various concerns in a way that does not accommodate to a standard model of trying to generalise one's own maxims of action. But the fact that moral proceduralism is unable to solve all normative conflicts does not mean that it can be of little or no use as we make decisions about various domains of life - including, above all our fundamental moral intuitions about justice and fairness in society. I have argued above that, ever since Kant's formulation of the categorical imperative of morality, there is a limitation in this mode of reasoning because it does not lend itself to making decisions among competing general claims: e.g., justice versus liberty. But, at the same time, it is this kind of categorical imperative that opens itself to the claim to universalism that underpins Archer's

22 This is exactly what fractured reflexivity represents: the inability to articulate a functional modus vivendi.

${ }^{23}$ Archer summarises her critique thus: '[b] ecause concerns are not reducible to emotions, then it is important not to turn the commentary into some sort of moral direction finder, which was the tendency found unacceptable in Taylor' (2000: 232). On Archer's engagement with Taylor, see also (2000: 130, 195, 216, 224). Following what we have discussed in these two chapters, Taylor's emphasis on the linguistic articulation of our normative evaluations in a cosmos that is objectively composed of moral goods may lead him also towards a form of central conflation. 
own principle of humanity. Differently put, there can be no ultimate idea of relational goods and evils without the possibility of us linking our personal decisions and concerns to that which may be the right course of action for the species as a whole. Will this always and unequivocally offer sound moral guidance? Surely not, but even in this weakened sense it remains a key dimension of our normative imagination. 


\title{
$8 \quad$ Reproduction of Life
}

\author{
Luc Boltanski
}

The wide array of theoretical and substantive questions that are currently being discussed in connection to Luc Boltanski's work speaks for itself about its growing status in current sociology and social theory. We seem to have crossed, or at the very least about to cross, that always ambiguous threshold that marks a writer's status as a 'contemporary classics'. ${ }^{1}$ As we have done in previous chapters, here I offer an assessment of neither Boltanski's whole body of work nor his overall theoretical perspective. I am interested instead in the particular contributions that his sociology makes to our threefold quest: first, the relationships between sociological and philosophical knowledge-claims; second, the conceptualisation of the normative in society; and third, the notions of the human and humanity that are effectively at work, indeed underpin, his sociology. In so doing, I shall be drawing from a variety of written sources but will pay special attention to his work on reproduction and abortion.

\section{I}

The normative complexities of debates on abortion make it a particularly salient subject through which to explore, for instance, the interconnections between 'lay' and 'expert' grounds for justification and critique that are central to Boltanski's sociological approach. Questions to do with abortion, and the argument applies also to euthanasia, also illustrate particularly vividly the substantive purchase of the definition of the normative that I defend in this book; namely, ideas of value that ultimately refer back to such questions as 'what is a human being' or what makes human life human. ${ }^{2}$ Boltanski is right when he argues that understanding abortion

${ }^{1}$ For a general overview, including several interviews and materials previously unavailable in English, see Susen and Turner (2015). See also the special issue of Thesis Eleven on Boltanski that was edited by Craig Browne and came out in October 2014.

${ }^{2}$ See, towards the end of Chapter 3, Parsons's comment that abortion makes it clear the importance of distinguishing between an organism and a person. Indeed, Parsons explicitly connects abortion to questions of 'brain death'. 
does not consist in trying to answer the question when does a human life actually start, because this gives the wrong impression that science can answer these kinds of issues unequivocally, while in fact they remain fundamentally open as philosophical questions. At stake here is not something that can be settled empirically but a whole set of complicated issues that require a wider approach: what is, and how do we acknowledge socially, a life that is indeed human. This is a challenging question for the social sciences because our disciplines have a major deficit when approaching these kinds of philosophical concerns: 'the social sciences have failed ... to pay sufficient attention to the creation of human beings' (2013: 24, my italics).

From a social scientific standpoint, a major feature of abortion is the fact that it is a universal practice that can be found across history and cultures. At the same time, the legalisation of abortion in most Western countries, plus our contemporary ability to technologically manipulate embryos and foetuses as a type of 'being' that is simultaneously treated as human and non-human, creates a whole new array of normative difficulties. One major part of the problem lies in how abortion and engendering techniques are similar in design but lead to opposite results with regard to the foetus; indeed, they are underpinned by the same ontological predicament that the foetus is an object of legitimate instrumental manipulation. These remain open as normative dilemmas because the fast-growing range of medical procedures that have become available for the manipulation of foetuses actually increases the difficulties in adjudicating on the key question of their human status. As technological advancements enhance the possibilities of both engendering and abortion, the strictly human status of these beings cannot be unproblematically ascertained; differently put, they have become the latest expression of key challenges posed by the historicisation of humanity's defining anthropological features.

The contemporary predicament stands between the Scylla of constructivism - a pure notion of the creation of human beings continues to remains troublesome - and the Charybdis of essentialism - human beings' constitutive properties should be subject to no instrumental manipulation whatsoever. While they point in opposite directions with regard to the continuation of a life that may eventually be deemed human, abortion and engendering techniques are equally hard-pressed to suspend the human status of the foetus they are about to manipulate: 'we have to deal with a humanity that is no longer self-evident, that is no longer simply given; nevertheless, we have not brought ourselves to think that humanity can be deliberately and methodically fabricated' (2013: 248). ${ }^{3}$ Boltanski

${ }^{3}$ Both the French and English editions of Boltanski's book bear as subtitle 'A sociology of engendering and abortion' and although this dual focus is to some extent reflected in the 
approaches the study of abortion by making apparent the duality that is constitutive of the human predicament: humans live through ineluctable tensions between the organic and the cultural, the biological and the social, the individual and the collective, the general and the singular. Below I will explore in some detail the different levels in which this duality of the human condition finds expression within Boltanski's work on abortion - the ontological status of the foetus, the epistemological construction of abortion and the tension between normative and descriptive claims - but before I do this I should briefly like to situate these reflections within his wider sociological outlook.

Indeed, twice in The Foetal Condition Boltanski makes the point that the theoretical results of this investigation, which was first published in 2004, challenge the 'principle of common humanity' that he had previously elaborated in the early 1990s (2013: 56-7, 234-7). In this previous work On fustification, Boltanski and Laurent Thévenot took up explicitly questions of justice and normative justifications as central for the sociology study of modern societies. ${ }^{4}$ On the one hand, they built their argument on the conventionally sociological idea of the differentiation of modern societies in various, semi-autonomous, functional spheres that have their own logic. But while sociological approaches have tended to emphasise the strictly functional dynamics of differentiation, Boltanski and Thévenot make their case on normative grounds: there is an internal differentiation of various spheres of justice and these spheres are themselves connected to key anthropological competences that make human beings capable of justification. ${ }^{5}$ It is on the basis of a sociological account of the centrality of justice in the functional organisation of modern societies that a philosophical argument on the salience of a principle of common humanity becomes apparent. Justice as a social institution mirrors justification as a human capability as they are equally dependent on a universalistic principle of humanity: on the one hand, institutions are in principle open to everyone but in practice they create hierarchies that allow for the uneven distribution of resources inside them; on the other hand, all individual human beings are equally endowed with the competences to appeal to general principles but in practice they are unequally positioned to make effective use of these competences.

book's main arguments, both theoretically and empirically it centres more on abortion. Engendering techniques play instead the counterfactual role of helping bring out the normative consequences of various lines of argument.

${ }^{4}$ See Peter Wagner (1999) for a general assessment of this book's main arguments and its critical reception.

${ }^{5}$ In addition to Parsons and Luhmann in the functionalist tradition, Weber's value spheres and Bourdieu's fields also define differentiation in functional fashion. In political philosophy, Michael Walzer's (1984) Spheres of Fustice offers a convergent argument where differentiation is seen in normative terms. 
On fustification is in fact built around a combination of descriptive and normative arguments; sociological observation and philosophical reflection are equally present and in permanent interaction. The very need to articulate a universalistic principle of humanity comes out of an engagement with the key predicament of the Western tradition of political philosophy: 'human beings are sharply distinguished from other entities and are brought together among themselves, furthermore, by their fundamental equality' (Boltanski and Thévenot 2006: 13). The sociological argument depends, therefore, on the anthropological capacities that make this idea of common humanity operative for the purposes of the constitution of a social order. A 'political metaphysics' then ensues that ought to be able to articulate more fully a 'higher common principle', which in turn depends on the 'imperative to justify that underlies the possibility of coordinating human behaviour' (Boltanski and Thévenot 2006: 37). Far from being mere idealistic talk, this imperative to justify becomes a fundamental aspect of how social actors construe stable social arrangements whose very legitimacy depends on the normative grounds on which social institutions are construed and publicly justified. Rather than an insurmountable contradiction between lay morality, on the one hand, and the technical arguments of sociology or moral philosophy, on the other, Boltanski and Thévenot contend that the solutions they have found in the ways in which people actually try to reach agreement 'on the practical level' are indeed in correspondence with 'the abstract models' that philosophers have been envisaging over centuries (2006: 65). Far from being built on opposite or conflicting epistemic grounds, sociologists are here subject to ontological requirements that mirror those of social actors themselves: whether and how they articulate a 'higher common principle' that may serve as justification for what people do in society. ${ }^{6}$

For our purposes, the justification of the universality of this principle of humanity is twofold. There is, first, the requirement of transcending one's

${ }^{6}$ We have also discussed the relationships between lay and experts' knowledge-claims in Chapter 5. In his highly critical review of On fustification, Axel Honneth (2010) questions all these decisions: the selection of moral philosophical texts is untenable as it misses alternative philosophical traditions (such as republicanism), the equalisation of lay and expert justification is inadequate because it makes strong normative assessments effectively impossible, and the alleged centrality of normative justifications underestimates the resilience and externality of power relations. To Honneth, this leads to two fundamental difficulties in Boltanski and Thévenot's project: there is first the epistemological flaw of idealism as the social is conceived as only made out of normative considerations that are always at hand for actors to use; second, there is the normative flaw that, as they blur any epistemic separation between description and normativity, immanent critique (as the key task for critical theory) becomes impossible. The relationships between critical theory and Boltanski's pragmatic sociology of critique have attracted much attention, see Basaure (2011), Browne (2014a, 2014b) Celikates (2006) and Diken (2015). 
own interests because justifications imply that we are able to adopt a more general standpoint which, if not fully impartial, is at least able to include a wide range of social positions. Thus, in a formulation that resonates with the cosmopolitan language of the Enlightenment, and indeed with some of the arguments we discussed in Chapter 2 on Arendt, Boltanski and Thévenot (2006: 39) claim that 'if one takes to heart the "general interests of humanity," worries about them, speaks in their name, one is transforming a private desire associated with an embodied attachment (to a member of one's family) into a disembodied generic relation that can no longer be the object of individual bodily satisfaction'. The human ability to think beyond one's needs, desires or interests implies the possibility of selftranscendence that, however imperfect, is built into our conceptions of impartiality and justice. Second, a universalistic principle of humanity cannot work if flat and undifferentiated; it requires that 'personal particularities' are indeed 'preserved' (Boltanski and Thévenot 2006: 75). In modern societies, people do have different interests, needs, abilities and concerns and it is because they do that we need to learn to live with others. We then become able to overcome contextual constraints at particular junctures and assess various situations from different standpoints.

While their emphasis is more on the normative underpinnings than on the functional performance of social institutions, On Fustification accepts that social orders are organised around different values that will in due course inevitably enter into conflict. Against Weber's metaphor of warring gods that are only content with absolute submission to their own particular value sphere, this model of justice is explicitly geared towards the avoidance of normative breakdown; the authors are ultimately interested in 'an account of humanity that is confronted with unequal worths and that manages nonetheless to avoid civil war' (Boltanski and Thévenot 2006: 76). In their case, the core argument lies in the identification of what exactly we mean by justice in each of their six modern polities or worlds: the 'inspired polity' that centres on grace and creative transcendence, the 'domestic polity' that focuses on authority and communal bonds, the 'polity of fame' that highlights various forms of social recognition, the 'civic polity' that deals with the collective organisation interests, 'the market polity' that trades on competition and the satisfaction of needs, and finally the 'industrial polity' that organises production and professional life (2012: 285-6). ${ }^{7}$

A key argument in On Fustification is, therefore, that at the same time as the unequal distribution of worth across society is common occurrence in modernity - it is part and parcel of the functional requirements of modern

${ }^{7}$ See also Boltanski and Thévenot (1999) where these 'polities' or orders of 'worth' are referred to as 'worlds' and the various components of each is slightly different. 
society - the universalistic underpinning of a principle of humanity requires that no one is completely left out at least of some area of worth. While there are bound to be clashes and conflicts between these different polities, and all sorts of constraints will make a difference to our ability to access and enjoy their rewards, universal accessibility and avoidance of total exclusion remain a major normative principle. ${ }^{8}$ Ideas of common dignity, common good, and justice as equality offer a threshold below which no human being can or ought to fall within any domain of worth. Over time, modern societies have developed institutions and regulations that try to prevent that certain particular individuals or groups fall completely outside a certain area of worth: the politics of inclusion of civil rights movements, for instance, as those which pushed for the end of slavery and the widening of the franchise. But Boltanski and Thévenot also contend that in modern societies worth is primarily attributed to domains rather than to individuals: modern societies develop mechanisms, procedures and institutions that seek to safeguard the integrity of one arena if and when it is being threatened by others: the autonomy and worth of education and the arts suffer as they are encroached by politics or the economy.

Abortion is in that sense unique because it challenges the notion that an inviolable threshold underpins all areas of worth, and Boltanski explicitly expands on this point at the very end of The Foetal Condition. There, he argues that his earlier elaboration of the principle of humanity did not account fully for the tension between the need to rank 'human beings in situations where they interact as function of their respective worths' and the opposite need 'of respecting their fundamental equality by virtue of their participation in a common humanity' (2013: 249). It is however this very tension that now needs unpacking. A better understanding of the actual operation of the principle of humanity still needs to be able to account for the fact that, with abortion, results cannot be undone. What makes abortion such a key case is the fact that it targets 'applicants for entrance into humanity' and is therefore 'irreversible' (Boltanski 2013: 236). Abortion challenges a traditional understanding of the universalistic principle of humanity because that very humanity is an explicit object of contestation. ${ }^{9}$ But before we can fully appreciate what is at stake here, and

${ }^{8}$ This possibility of full inclusion is also central to Parsons and Luhmann's 'standard' arguments on functional differentiation (Stichweh 2008). See also, in Chapter 3, Parsons's argument on the evolutionary importance of cultural universalism.

${ }^{9}$ To be sure, in such extreme situations as those of inmates of concentration camps we speak of a complete denegation of human dignity - and the case can also be made for extreme cases of destitution whereby people's right to make these claims remain formally open but the substantive exercise of such rights is impossible in practice. As he recounts his experience as a camp inmate, Emmanuel Levinas (1990b: 151-3) makes the point that 
indeed how we should finally assess Boltanski's position on abortion, we still need to take a detour through his ideas of society and sociological knowledge. This is how he defines the social in this context:

[a] being is social ... or is part of society when the human members of a collective ... or at least some of them, deem that the relationship maintained with that being concerns and engages the collective as a whole... I shall call a being a social being only when these associative claims are activated, that is, when the relation the beings maintain with others is apt to cause a problem for the persons that are in the relationship with them. (Boltanski 2013: 151, my italics)

There are several aspects of this definition that are worth paying attention to. Society is here seen as relational: it involves active participation, requires that beings invoke the totality of collective life and also that the relationships thus construed cause a problem for at least some people. Society is not defined as fundamentally normative, but references to the collective as a whole, participation and problems do speak to the normative side of social life. Boltanski refers positively to Bruno Latour's work in this context and, with Latour, he understands that the idea of society must include relations to beings other than humans. Material objects not least among them the physical presence of the human body - are surely central to our views of what society is. Sociality depends on the materiality of objects because, as we will see below, human justice centres on a principle of equivalence that requires the transitivity of objects. But very much against Latour's proposition on the need to abolish or at least soften the distinction between humans and non-humans, Boltanski not only separates the two; he actually reinforces their dissociation at a deeper level. Methodologically, this difference is important because it is only the experience of human beings that gives credence to society; normatively, it matters because our main object of concern lies in the consequences of social life for human beings themselves. Crucially for his work on abortion, it is the indeterminacy of the human status of the foetus that allows for its treatment as an 'actant'. But this again goes against Latour's ontological insight, because for Boltanski the key to our conceptualisation of foetuses is that it lacks of agency $(2013: 126-7,151) .{ }^{10}$ Indeed, already

this sense of human dignity can be simultaneously denied by other human beings while afforded, paradoxically, by animals who reminded inmates that they still are human beings: Bobby the dog became, for Levinas, 'the last Kantian in Nazi Germany'. See the fascinating discussion of this insight in Calarco (2008: 55-77). See also Clark (2007), Finkielkraut (2001: 3-4), Haraway (2008: 22-4).

${ }^{10}$ It is a generic of sense agency that moderate posthumanists seek to widen in order to move beyond an anthropocentric view of humanity (Connolly 2011: 35). See Guggenheim and Potthast (2012) for further discussion of the relationships between Latour and Boltanski's approaches. 
a decade earlier Boltanski (2012: 14) had similarly argued that an idea of society included not only those 'incorporated bodies known as persons ... but also the conventions that define the humanity of persons and qualify their value' (my italics). In other definitions, however, the emphasis was on the ways in which the humanity of human beings defined their position in terms of different valuations. That these are referred to as conventions is just what we would expect from a sociologist - normative ideas change and are indeed a social construct. But because they touch on the humanity of human beings, the way these normative ideas change, the permissions they grant and above all the limits they set, are of key importance in that they define what is deemed fair or acceptable in society. The bodily constitution of human beings is indeed subject to much social and historical change and variation, but it also has limits, and the social experiences we are confronted with can only be construed in so many ways: experiences of physical abuse and psychological degradation can be variously construed, but they can hardly be turned into positive events in their own right. Values are relative and socially construed but their consequences are not necessarily so; the status of what is a human being may change and be deemed relative and problematic and yet the implications of these changes can become dramatic and have consequences that are indeed irreversible.

Boltanski argues that one of our key anthropological capacities is our ability to ponder over equivalences and assess equality or comparability between things. It is on the grounds of this anthropological skill that 'justice is ensured in a political order when the distribution of what has value among persons is carried out according to a principle of equality' (2012: 14). ${ }^{11}$ The actualisation of these principles is of course highly diverse and can become a source of individual or even collective anxiety: justice and injustice are key to most of what humans do in society. It is on the grounds of claims to justice and against injustice that we become able to make explicit the principles 'of what constitutes the value of things and people' (2012: 26). Justice is then understood both as a property of social relations and as a human intuition; it refers to the relations between persons and things. Far from being a purely ideal notion that works in the abstract, Boltanski contends the importance of justice has precisely to do with its relevance for construing equivalences between objects in society.

The sociological centrality of justice is also warranted on the grounds that most of our social life takes place within a variety of social

${ }^{11}$ Injustice is conversely defined as 'a division of material or immaterial goods that does not respect the legitimate order of worth among persons' (2012: 14). See Chapter 4, on Hans Jonas, for a principle of justice that is construed not on the grounds of equality (in his case, reciprocity) but of unequal responsibility. 
institutions, all of which are ultimately dependent for their functioning on some conception of equality. While the successful functional outputs of modern institutions have to do with their material performance, their normative orientation has to do with the consequences of these actions and objects in the lives of human beings. The main thrust of On fustification is, correctly in my view, that the modernity of modern societies centres on the increasing salience of several institutions that are constituted around this principle of dual functional (material) and normative (ideal) operation (Chernilo 2014). Justice as equality operates in differentiated fashion because different functional and normative performances are expected from different fields, because people's 'worth' in one field does not automatically translate into others and, last but not least, because this internal differentiation widens the perspectives that then allow for our various attempts at impartiality. On all grounds, I should like to contend, justice is ultimately underpinned by the universality of a principle of common humanity.

There are additional historical reasons that explain the centrality of justice for the sociologist. To Boltanski, the nascent sociological imagination of the second half of the nineteenth century had two primary objects of concern: religion and poverty. The importance of the former explains sociology's interest in the problem of illusions, beliefs and truths, while the salience of the latter accounts for its observations about inequality, class and power. Sociology has then faced from the start the ultimately unsolvable problem of trying to account empirically for situations that are based on contradictions: conceptions of right and wrong that follow from mistaken beliefs; material distributions that create injustice rather than fairness. Confronted with these challenges from its inception, Boltanski argues that sociology has advanced two equally unsatisfactory answers. One first option has been to appeal to some transcendental principle that is able to rationally explain the irrational. In this case, history, progress, providence all betray sociology's commitment to immanence by falling back to principles that lie not only outside society but ultimately cannot be comprehended sociologically. The second alternative has been for sociology to abandon its own interest in critique, in which case it not only condemns itself to practical irrelevance but also accepts that the world is in fact beyond rational comprehension and incapable of improvement. By taking either option, sociology has only been able to reveal the inequalities it observes without however 'clarifying the position of justice on the basis of which they can be defined as such' (2012: 26). The unsuccessful resolution of this challenge has been for sociology to endow social actors 'with means of calculation of which they themselves are unaware' - that is, with a set of anthropological qualities that only 
work because they operate behind people's backs (2012: 83). Contemporary sociology not only works with an exaggerated heuristics of evil and suspicion but also fails to notice the extent to which lay accounts are already experienced and described in the language of the social sciences. Boltanski's critique of the mainstream sociological imagination is that the constructionist predicament that attributes social causes to all phenomena results ultimately in two equally flawed propositions: either everything is related to everything else or everything can be reduced to the same social causes $(2012: 280, \mathrm{n}$. 36). In a way that echoes the criticism I raised in the Introduction against a certain reductionism that has become the trademark of contemporary sociology, Boltanski assesses thus the work of his former teacher Pierre Bourdieu:

one can interpret the behaviour of anyone at all, when one has understood that these behaviours are always oriented towards the search for satisfaction of personal interests, the most widespread being the interest in gaining power ("here is everything about power") and, consequently, that relations among persons can always be reduced to "power relations" between those who have power and those who do not. This universal key makes it possible not only to deprecate all claims made by others that they are acting for the common good by revealing the underlying interests, but also, in extreme cases, to claim for oneself, in the name of realism, the right to perform actions that abandon the aim of justice in favour of the quest for power. (Boltanski 2012: 24-5) ${ }^{12}$

If seen as socially construed and subject to the strategic logic of power relations, normative considerations remain epiphenomenal at best. And at worst they obtain from more or less conscious attempt to improve one's own bargaining position; they are thus conceived as instrumental rather than normative claims. To move beyond this self-imposed normative restriction within sociology results in the need to reconsider two of its crucial arguments. First, there are pre-social aspects in the actors' capacities for judgement, critique and justice and these are to be treated as relatively independent vis-à-vis social factors and influences - these are precisely the kind of anthropological features that we have been looking at throughout this book. Second, social life does not centre on claims to justice but, to the extent that claims to justice are bound to emerge in all structural settings, they are to be treated as independent vis-à-vis actors' interests and strategic positions. Taken together, these propositions make it necessary that we reject the idea that domination and power, strategic self-presentation and instrumental rationality define both our anthropological capacities and the key elements of social life itself: without a notion

${ }^{12}$ For a systematic comparison between Boltanski and Bourdieu's approaches, see Susen (2015). 
that there are autonomous anthropological properties, we will not succeed in conceptualising the normative in society.

The argument that now emerges is that the social sciences do in fact operate with an implicit 'metaphysical capacity' that is universally available to all human beings (2012: 43); there is a general competence that makes possible for humans to understand the connections they enter into as a social bond. This also allows humans to connect what happens to them in their relations to other human beings and objects in the world: humans are able to make reference 'to something other than persons, something that transcends persons' $(2012: 44)$. To the same extent that we make connections between objects, persons and situations in the world, we are then also able to transcend our physical engagement with the world in order to pass judgement on whether these situations are fair or not. The fact that this property cannot be exercised outside society does not fundamentally alter the fact that its ultimate constitution is just not itself social: '[i]t is precisely the imputation of an unknowable power, a power never exhausted by the acts that reveal it, that qualifies the person as a person' (2012: 65). Sociology cannot fulfil its descriptive tasks without the philosophical analytical tools that will then help it unpack the properties humans have 'as persons, prior to any qualification' (2012: 57).

This ability to transcend one's own position as a singular person, and to make claims to justice that are based on a general principle of equivalence, are a key anthropological contribution to social life that the social sciences will be able to fully understand only to the extent that they allow in philosophical arguments. In Chapter 2 we saw that the human ability for self-transcendence lies at the centre of Hannah Arendt's contribution to this same problem, and Boltanski's sociological insight matters here because he is not only prepared to accept, but openly advocates for, what he refers to as 'metaphysical arguments'. Sociological and philosophical knowledge-claims are not to be conflated; indeed, from a strictly sociological perspective these questions of principle may never be regarded as of fundamental importance. Yet they are required:

[w] e do not regard this underlying metaphysics as a failing in the social sciences. It is precisely by having recourse to conceptualizations that can be viewed as metaphysical that the social sciences recognize the role played by the human capacity to conclude justifiable agreements in the construction of society. (2012:44)

Society's very sociality is constituted through pre- and non-social forms, and in order to account for the social we need to give room to these metaphysical capacities that, in so far as they are not social, may be best captured philosophically.

Boltanski's sociological work also pays attention to those aspects of human existence that are not exclusively social. To be sure, questions of 
justice have indeed grown increasingly central to modern society, but not all domains of social life are ruled or organised by principles of justice; this is what makes his work on reproduction and abortion, but also his writing on love, of particular interest. We have seen that Boltanski's definition of the social requires that persons and objects interact and that this is what warrants the centrality of justice in his argument: 'the person-thing relation undoubtedly constitutes a central node in the ordinary metaphysics of members of our society' (2012: 69). But there are also two alternative regimes of human relations whose operations differ from those of regimes of justice: there are regimes of violence, whereby people are not treated as persons but only as objects, and there are also regimes of love or agape, where the social world is populated only by persons and without any reference at all to objects. ${ }^{13}$

Boltanski's work on agape - an idea of love for another human being that is fully devoid of instrumental gain, moral justification and even satisfaction of emotional needs - focuses on those aspects of social life that are not based on the principle of the equivalence of objects that is central to ideas of justice. A sociology of agape does not take the equivalence of justice as its fundamental observation but rather concentrates on gratuitous devotion and selflessness (2012: 146-8). Theological in origin, ideas of justice as equivalence and love as gratuitousness are now extensively applied in social life: justice is interested in the general to the same extent that agape is in the particular, and agape transcends justice because neither discursive articulation nor impartiality is ultimately adequate to grasp our experiences of it (2012: 111). Agape is explicitly defined as 'not an interactionist model' and as such it remains untouched by the fundamental principle that 'persons incorporate anticipation of the responses of others into their own behaviour' (2012: 149). The metaphysical understanding of our anthropological capacities is also central to agape: there is, Boltanski contends, an 'intuitive understanding of agape that I believe all of us share' (2012: 101, my italics). We may construe the structural transformations that mark the rise of modernity as a transition from the predominance of agape as an interpersonal bond to the predominance of justice as a social relation. But this does not mean, of course, that there was no justice in

13 Violence, says Boltanski, 'ignores persons, and, as many have observed, by concentrating on things it opens up the possibility of treating human beings as things' (2012: 72). For its part, '[a]gape exempts itself from equivalence - that is, from the existence of a stabilized relation between things and persons - in order to endow itself with persons considered as such' (2012: 75). Even if violence has not in itself been a major theme for sociological research, arguably one of sociology's most basic observations - say, in Weber's discussion of legitimacy - is the fact that naked force alone provides no stability to social orders. What is discussed here as 'agape' has also been rendered in English as 'affective regimes' (Boltanski and Thévenot 1999: 362). 
premodern times or that there is no agape in modern institutions; it is their prevalence that is different in different historical constellations. In turn, we may reframe the critique of proceduralism that has accompanied throughout as another way of saying that not all forms of social relations are to be reduced to a formula of justice as equivalence: unequal treatment may also be morally acceptable and even desirable. ${ }^{14}$

We can summarise three main results from our discussion so far. First, the inclusion of agape is challenging for contemporary sociology because of its insight that not all actions in society are social in the sense of having an ulterior motive that is to be translated into power, influence or material gain. We have repeatedly maintained that there is something deeply flawed in the sociological reductionism that claims to be able to anticipate all motives with reference to the actors' social background (class, gender, ethnicity, etc.). This critique we may call that of the imperialism of reciprocity. ${ }^{15}$ Second, there is also the argument that an adequate definition of society does not comprise only social elements. The materiality of objects and the humanity of persons are irreducible to one another, and indeed to society itself, but they are fundamental to the regimes that are organised under the formula 'justice as equality'. Justice is the most fundamental principle for the functioning of modern societies, both in its performative and normative registers, but does not exhaust social life. Third, there is finally the metaphysical reference to our general anthropological capacities. They are referred to as metaphysical because their status challenges sociological conventions about social construction, on the one hand, and the subordination ideal factors (i.e. normative ideas) to material ones (strategy, domination, etc.), on the other. The existence of these capacities is thought to be previous and independent vis-à-vis society (persons exist as persons, agape and justice are universal intuitions) and their study lies at the level of presuppositions and normative implications rather than being subject to the empirical/theoretical rules of scientific discourse.

II

If we now go back to his study on abortion and reproduction, we have mentioned that Boltanski himself suggests that this work poses

${ }^{14}$ To that extent, these claims are compatible with Hans Jonas's argument that responsibility as a human phenomenon does not depend on the justifications given about it in society but is founded in our 'natural' or 'anthropological' capabilities. See Chapter 4.

${ }^{15}$ I will not be pursuing this here, but agape is challenging also at a methodological level because it can only be experienced in the first-person perspective of the actor. The required sociological move to the external perspective of the observer, which implies reflexive critical distance and discursive tools, marks precisely a move out of agape and towards a fully social domain where justice must prevail (2012: 150-5). 
challenges to the universality of the principle of common humanity that was key to On fustification. The core issue he raises in this regard is referred to as the 'ontological manipulation of the foetus': because it is potentially subject to abortion but also to techniques of artificial insemination, the foetus can be defined in theory, but also treated in practice, in openly contradictory ways (2013: 103). Before the twentieth century, abortion belonged to a relatively rare set of practices that had been universally practised, often tolerated, but in all cases they remained hidden from the public eye. Even as it is now decriminalised in most Western countries, its explicit normative justification remains problematic because its construction as a right, as something we can unproblematically treat as a value, remains highly controversial. More often than not, abortion is seen as a form of lesser evil rather than as a good in itself (2013: 236-7). As he makes this argument, Boltanski contends that this is not to do with his own moral position on abortion but with the fact that women themselves experience it as a tragic event (2013: 59). Because it touches on the definition of what is a human being, and the agents who have the power to make decisions over the humanity of human beings, abortion is a prime example of the difficulties modern societies face in culturally dealing with normative contradictions that are not only about social and cultural practices (2012: 155). ${ }^{16}$

The book on abortion is organised around the distinction between 'flesh' and 'speech'; that is, the fact that organic (flesh) and social (speech) factors need both to be included into our understandings of the human. For the status of human to be granted on a particular being, that which has been 'engendered through flesh' needs also 'confirm [ation] through speech': the constitutive duality of human nature is explicitly taken up (2013: 45). The physical entity that becomes implanted inside a women's body is demarcated from the one that, through speech, may or may not be brought onto existence as a full member of the sociocultural world. It is only when both planes are being reconciled that a human life proper can be said to have started: the humanity of human beings is marked neither at the moment of conception nor is it associated with any particular stage of organic development. It is rather defined through a highly variable moment in which consecration through flesh and speech

\footnotetext{
16 To that extent, I disagree with Bridget Fowler's (2015: 75) interpretation that 'in contrast with the stance opposing abortion practices on moral grounds, he [Boltanski] makes a powerful case for the moral nature of abortion itself'. On the contrary, I think that Boltanksi remains consciously vague with regard to whether his position is for or against abortion. But given that his argument is eventually that abortion is to be accepted and made legal but cannot be positively promoted, I would argue that his normative position cannot be depicted as pro-abortion (even if, openly, he is not against it either). See also the last section of this chapter.
} 
coalesce. An 'authentic foetus' is then referred to, and indeed treated, as a 'real' human being whereas, conversely, this status is systematically negated for a 'tumoral foetus', which is conceived as a passive, inert being. Ultimate acceptance in society is what marks the difference between authentic and tumoral foetuses, and as soon as this takes place a clear border between the two must be erected: it lies upon states to 'inscribe them in legal or quasi-legal categories so as to solidify them and make the lines difficult to cross' (2013: 130). The sociocultural dimension of our humanity is granted to beings as they become part of a world that is symbolically prearranged for them. Their singularity as unique human beings takes place through this process of sociocultural confirmation (2013: 47-9).

Both tumoral and authentic foetuses are located inside a woman's body and while the ultimate social confirmation of the humanity of a being belongs to some kind of supra-individual agent, women do retain ultimate power over the organic continuity of the foetus. The gender dimension of political power is thus brought into the open: while traditionally men have had control over political society, only women have retained control over life itself (2013: 53). Because the creation of human beings requires that both forms of confirmation come together, abortion can be seen as the ultimate countercultural form of feminine power:

While engendering through flesh manifests the concretization of a woman's power in the first place ... confirmation through speech is embedded in a relation of authority. It cannot be otherwise, given the role that this confirmation plays in the establishment of human difference, whose structure is itself the institutional order ... It follows that no human being can possess in and of herself the authority necessary to create a new human being and deposit it in the world. This authority is received from another, who must be credited if the recipient is to act. (2013: 63)

If in the past the act of public confirmation 'through speech' took as reference point a divine connection, the clan or even the state, in contemporary society this is the role of the 'parental project', which refers to the anticipated normative framework within which the future existence of this human-to-be can be securely placed. In modern societies, parental projects are of course highly varied and do not respond only to traditional ideas of the nuclear family. But parental projects remain normative in the sense that they are ultimately concerned with whether the new being is to be offered conditions that can lead to developing a fulfilling human life. The asymmetry in the situation of women is again apparent, however, because while the decision to complete a pregnancy is construed as a parental project, the decision to abort lies ultimately on the woman herself. 
At the same time that a process of ontological manipulation of the foetus makes this separation between authentic and tumoral foetus possible, further questions are constantly raised by the emergence of a third type of foetus, the 'techno foetus', that is a direct result of modern insemination techniques. While 'successful' insemination turns techno foetuses into authentic ones, failures are common occurrence in insemination procedures. Boltanksi then argues that differences in treatment between tumoral and techno foetuses are difficult to explain normatively; the central dilemma being the different ways in which both types of beings belong in their natural and social environments. The state - that is, the laws and institutions that regulate abortion and insemination - registers in a very different way the treatment of those beings whose human status remains in limbo. The techno-foetus resides in the highly complex institutional environment that is provided by state institutions, but decisions on abortion remain necessarily private in a way that the disposal of failed techno foetuses is not. In the latter case, the claim to legitimate management and disposal belongs to the collective authority of state and it is because no 'singular person' may or may not confirm it within a parental project that the techno foetus takes 'on a higher level of generality, and make[s] it the focus of debates concerning not cases associated with particular situations but rather the question of "the human" in the broadest sense of the term, the question of the origins, contours and future of "humanity"' (2013: 143).

Technology bears particularly intensely on our definitions of the human because of its intricate connections to our anthropological capacities; organic life and social institutions create a space within which the most general questions about the status of our shared humanity can be raised and attract wider public interest - this is, as we have indicated repeatedly, a major feature of debates on (post)humanism. Technological questions about available treatments and normative questions about the status of the foetus come together, Boltanski argues, as medical practitioners have to decide whether, under particular circumstances, the woman or the foetus is the patient to whom they have a fiduciary responsibility (2013: 139). The threshold of time elapsed for abortion to be considered legal seems to reflect, among other issues, the uneasiness about how to justify the difference in treatment between an abortable foetus and a premature infant (2013: 137). In turn, this is compatible with the proviso that allows medical practitioners to withdraw from the practice of abortion. If justified by the state, abortion is legal and ought to be carried out safely under medical supervision; yet no individual can be forced to practise it. Because they problematise our human status, technological interventions have implications on how we understand subjective individual rights as well as the 'holistic ... rights of the human species' (2013: 143-4). 
One of Boltanski's most original arguments lies arguably in how he traces back these normative and ontological questions to epistemological debates within the social sciences. He looks at the trajectory of these debates vis-à-vis social struggles over abortion by assessing the chain of arguments through which we have reached the current situation.

1. Starting in the mid-nineteenth century, a first essentialist conceptualisation of abortion expressed the conviction that, as soon as a being is implanted inside a woman's body, we are always already in the presence of a human being. The very possibility of socially construing this being as a foetus, and therefore of raising the question of its human status, was not available yet. Mostly religious in inspiration and based on an unquestioned connection between humanness and a divine creator, the properties of this new being were treated as transcendental and timeless (2013: 67-73).

2. The first wave of decriminalisation of abortion in the West, which started in the early 1970s, was able to gain traction because of the deconstruction of this essentialist view of human life: the creation of a new embryonic being that was not necessarily, automatically or immediately, seen as the emergence of a human being. By making visible the historicity of what had been treated as essentially timeless and the contingency of what had been regarded as necessary, deconstruction carries a particular ability for 'disqualifying the conventions that are still in force' (2013: 190). This is reinforced by the growing visibility of new social actors (i.e. the women's movement) for whom the old status quo was no longer legitimate. The key feature that makes deconstructionism such a powerful tool for critique lies precisely in the way in which it captures tendencies towards social change that are already under way.

3. The exercise in disassembling that is core to deconstructionism can only be sustained over time, however, if it abandons its purely critical mode; proponents of the new order must now embrace some form of social constructionism. Critique remains successful and may continue to evolve only to the extent that it is also able to explain what exactly are the mechanisms and resources through which new social phenomenain our case, engendering and abortion - are now to be treated as social facts; that is, how they have become ingrained in the social fabric through legislations, institutions and social policies. In Durkheimian fashion, Boltanski contends that engendering and abortion are indeed social facts to the extent that they reflect collective morality (inter alia, the growing equality of women in society that is reflected in the separation between sexuality and procreation). They are to be explained by other social facts (the pill allows for much greater control over engendering, and abortion was to be administered under state 
regulation) and they can be studied more objectively than ever before (for instance, as demographical trends that correlate women's education and number of children). There is now a whole array of technological equipments that make 'life in the womb' visible for the first time in human history. It is only in the last third of the twentieth century, and thanks to technological improvements, that the foetus has become a major ontological innovation: humans have created a type of being whose main feature lies in its contested status as a human being (2013: 103).

4. But the limitations of social constructionism become themselves apparent soon enough, and a new form of realism becomes necessary on three grounds. A first and somewhat paradoxical challenge faced by social constructionism is that it tends to rely on the rather naive acceptance of the truth-value of scientific facts: the authority of science becomes the incontestable source from which previous forms of patriarchal, religious or even political authority are to be continuously challenged. Yet the problem remains that the natural sciences themselves work on the assumption that our beliefs in current evidence must themselves remain provisional and open to contestation (2013: 188). Second, as mentioned, legalisation on abortion has in fact taken the form of 'decriminalisation': to the extent that it is practised within the law, abortion is no longer an offence. But the question of whether it can be justified with reference to positive normative claims remains contentious and requires of a more realist position: whether and under which circumstances can abortion be seen as a value. Third, realism is needed because the ontological being whose existence is at stake does bear some resemblance to human life. It is becoming increasingly hard to claim that a foetus is only a socially constructed being: abortion cannot be trivialised in this way.

It is this duality of human nature that explains these tensions and transitions: essentialism $\Rightarrow$ deconstructionism $\Rightarrow$ social constructionism $\Rightarrow$ realism in terms of the cognitive treatment of abortion. But it is my contention also that Boltanski's inability to make a positive case for it - for instance, his lack of treatment of the role of reproductive rights in the positive legitimisation of abortion - is sustained on an implicit primacy of the organic continuity between the foetus and the human over and against the sociocultural discontinuity between the two. Boltanski the sociologist seeks to unpack the intractability of these dilemmas as they are predicated on the ontological duality of human nature: social and cultural plasticity, on the one hand, and organic continuity and limitations, on the other. And yet citoyen Boltanski does not warrant equal weight to both and sides, albeit implicitly, with a notion on the ultimate primacy of the organic continuity of life. 


\section{III}

The final argument that I would like to make in this chapter has precisely to do with the relevance of critique as a social institution and the strict demarcation between description and normativity in sociology (2011). Boltanski argues that sociology ought to take seriously people's views about their own lifeworlds and that the differentiation between description and normativity is an essential but complicated task (2013: 234). He again resorts to the Durkheimian theme that his goal as empirical sociologist is to develop a sociology of moral facts rather than a moralising approach to sociology. This insight may be described as positivist in the same, soft, sense that Durkheim meant it; namely, a philosophical stance on the possibility and importance of successfully separating facts and norms, on the one hand, and the relative weight of empirical evidence, on the other. But as we look deeper into Boltanski's work, the actual justification of this argument is problematic - it is as if Boltanski offers only a halfhearted commitment to it and that he himself has become aware that it cannot be fully accomplished. Thus, for instance, he opens his book on abortion with the general statement that, because this is a new field of study for sociology, his work shall remain neutral vis-à-vis a normative view of it (2013: 2) - indeed, this is a proviso that he had also made before in relation to the development of a sociology of 'disputes' (2012: 4). This can be interpreted as if to suggest that a strict separation between the two registers is only justified provisionally, as if a lift of this temporary restriction on normative assessments is to be decided in relation to the advancements in sociological research: if cognitive maturity, empirical exhaustiveness and conceptual sophistication are to be regarded as the main criteria for scientific development, then the argument is that we need to wait until we have learned enough about the social facts we are interested in before we are allowed to venture into normative disquisitions. Two options may be said to follow here: either the 'Comtean' proposition that true sociological knowledge will eventually become sophisticated enough so as to bridge the gap between description and normativity, or else the 'Weberian' path that personal commitments are indeed allowed but must remain separate from our actual scientific practice. Boltanski compares several times his own position as a sociologist to that of a judge who must remain impartial as she listens to everyone and ponders not only what the evidence may tell her about a particular case but also about the meta-rules of whether some forms of evidence are more reliable than others - or indeed whether they are reliable at all (2012: 30,47). Interestingly, however, Boltanksi says nothing about what is surely the judge's most critical role: at the end of the trial, the judge commits to a certain version of events and reaches 
a reasoned conclusion that will take sides and apportion blame or responsibility. The whole point of a judge's impartiality during a trial is to allow the time and reflection so that she can reach a normative stance at the end of it. ${ }^{17}$

In terms of his own position within contemporary sociology, we know that at least part of Boltanski's reservations against connecting too closely description and normativity are based on the shortcomings of the mainstream 'critical' sociology that is inspired by Pierre Bourdieu. We have seen that his criticism of Bourdieu was twofold: first, that the anthropological competences that make normative critique possible for the social scientist are however regarded as unaccountable for actors themselves. Second, that in Bourdieu the motifs for normative critique are not at all normative: they are strategic and depend on the chances of success in the advancement of particular courses of action within a field of struggle, rather than being based on the grounds for critique and justification. While I agree with Boltanski's critique, it remains unclear to me why he refuses to make a more definitive move that rejects equally the radical separation of description of normativity and its conflation. Differently put, Boltanski is right in taking people's grounds for critique seriously, but then he shies away from the most significant consequence that follows: human beings' descriptions contain various forms of normative assessments and, conversely, most of our normative assessments are in turn construed around empirical descriptions. If Boltanski aims to retain the ultimate equivalence between lay and expert claims in so far as they provide grounds for critique, then we should focus on how the two tend to become connected, more or less carefully in different instances, rather than sticking to a somewhat dogmatic argument for their separation. Adequate sociological work requires that we pay special attention to the interplay between descriptive and normative propositions and this is in fact what makes so interesting the study of moral controversies to which Boltanski pays attention: describing the social world requires that we grasp fully what is normatively at stake. The goal is to be able to account for the autonomy of the normative in social life: the normative is not the centre of social life, but nor can it be reduced to power relations, material interests, performativity or identity politics (see Introduction).

Through the explicit articulation of the principle of common humanity - both in terms of its anthropological abilities and its social

${ }^{17}$ This, unless Boltanski's interpretation of the role of the judge follows an unreconstructed version of legal positivism: the judge's personal stance does not matter at all because everything is to remain subordinated to legal procedures and a strict separation between legality and morality. See Dworkin's (2008) Fustice in Robes for a different account of juridical impartiality. See also Habermas (2003b: 264) on the limitations of a judge model of justice in modern societies. 
actualisation - Boltanski has already made a major contribution to philosophical sociology as I am trying to delineate it in this book - even if he appears reluctant to acknowledge its implications in full. There are in fact several instances where Boltanski not only acknowledges that conventional understandings of the normative are insufficient but also criticises sociologists' unwillingness to move beyond formulaic conventions:

the very fact of giving full scope to the normative dimension of human behaviours or, on the contrary, the fact of claiming to absorb this dimension in arrangements of a different type, is what constitutes the chief dividing line among the various tendencies of the social sciences. (2013: 235)

Indeed, Boltanski's own sociological practies show a complicated and not fully reflexive relationship between description and normative.

The following statement, for instance, can hardly be construed as neutral in the sense that, in his book on abortion, his position leans towards its normative rejection: abortion is 'both necessary to conceptualize human difference and also, through the arbitrary violence that it exercises, unjustifiable' (2013: 6, my italics). As he expands on this point later on in the book, the argument is elaborated on as follows:

the fact that abortion was an act of violence committed on a being that had some relation to 'humanness', however difficult it might be to qualify, could not be completely set aside with a sweep of the hand, even if countered by the violence patently obvious in this case - done to women when abortion was practised under clandestine conditions. (2013: 166, my italics)

These are instances where Boltanski makes apparent his own struggles in bringing together his scientific commitment to neutrality and his personal uneasiness with the practice of abortion: does this wholly contaminate the results of his work? Not necessarily, but it does make difficult reading in relation to the opening statements about the neutrality and a sociology of moral facts rather than a moralising view of sociology. Boltanski argues that an adequate conception of the human is both social and organic at the same time, but his normative hesitations on abortion ultimately depend on his resort to a mild form of ethical naturalism: abortion is to be accepted but cannot be justified because the claim that foetus and human being share an organic continuity is more fundamental than the differences in the sociocultural space they occupy. It is only on this ground that a tension can be construed as to whether, for medical practitioners, the patient is the woman or the foetus. Because it presupposes the at least partial humanity of the foetus, an imputation of fiduciary responsibility from medical practitioners towards the foetus is built into his sociological description of abortion. In fact, the book on 
abortion shows with particular lucidity the methodological dimension of my idea of philosophical sociology: our normative choices in society are fundamentally informed by (pre)conceptions of the human, and the more we take questions about the human status of the foetus into consideration, the harder it remains for sociology to uphold only to its scientific dimension. Because at stake is the possibility of social manipulation of a being whose very human status is the object of controversy, this challenge cannot be resolved in cognitive terms alone: it requires threading also, and very carefully, in normative terms.

The criticism against too strict a separation between description and normativity can also be construed differently. If the reflexive capabilities of lay actors and social scientists are only to be distinguished as a matter of degree, we then ought to accept that we all get our orientations in the social world in the midst of a highly complex composite of descriptive puzzles and normative challenges. We may remain unable to make definitive normative arguments - accepting the legitimacy of a practice still does not amount to being able to justify it as a value - but then capturing this normative complexity is itself central to understanding how people's lives are actually experienced in their own lifeworlds. It is not so much whether we can or are able to clearly distinguish between the two but that, in the most important moments of our lives, this is not what we want to do nor, indeed, what we should do; too neat a separation between them becomes neither feasible nor desirable. Differently put: if justifications are central to what lay actors do in their own lifeworld and sociology has no epistemic privilege - why should sociologists not be putting normative arguments forward? Once again, the pervasiveness of normativity in society mirrors its pervasiveness in our own conceptual and descriptive propositions in the social sciences.

To an extent, Boltanski's $(2013: 58,194)$ own recourse to a phenomenology of moral categories here is exemplary (though far from unproblematic): he treats people's experiences seriously and reconstructs them first in their own terms and only then in a language that allows for greater theoretical articulation. But then he stops precisely at the point of having to do what actors do in their own lifeworlds: people do not stand back and refrain from normative assessments but rather thread, more or less successfully, more or less skilfully, over the complexities that connect both stances. This is again where our professional expertise in reflexivity does not grant any form of epistemological privilege but may become particularly useful. A sociologist's training may help her clarify the presuppositions and implications of competing approaches, how the tensions between individual and social goods are articulated and, crucially for my argument in this book, the implicit conceptions of the human being 
from which different arguments draw support. The kind of sociological descriptions that we are after are meant to be able to grasp those issues that people experience as sensitive, emotional and ultimately difficult to resolve in their very complexity: we need to develop a clearer sense of what normative descriptions may actually look like (see Chapter 2). What Boltanski's study on abortion makes particularly apparent is that we respond to issues related to our shared humanity in its dual organic and ideational side: from intimate to state-sanctioned violence, from religious beliefs to the organic continuities between different forms of beings, they ultimately make visible the tensional relationship between our anthropological constitution and the social and historical forces within which they find instantiation. 


\section{Epilogue}

From our contemporary standpoint, the idea of philosophical anthropology is bound to look abstract and remote: speculative reflections on ideas of the human that remain unconnected to specific sets of problems or particular contexts. But it is worth remembering that, as it started life in the early part of the twentieth century, philosophical anthropology was widely regarded as a second-class intellectual project. All original representatives of this tradition - Max Scheler, Ernst Cassirer, Helmuth Plessner - had to contend with the criticism that the field they were trying to establish was a 'mere' anthropology: it was poor science because its general approach was too philosophical, and it was poor philosophy because its themes were too empirical. Sympathetic as I am to this fascinating literature, it has not been my intention to resurrect it. My purpose was never to offer a complete or exhaustive set of anthropological features with which to define the human in human beings: possible omissions are so many that they hardly require further elaboration. My goal was instead to focus on those anthropological features that are of key importance at two levels: first, because they are autonomous vis-à-vis society even if their actualisation is itself social; second, because they allow us to articulate more explicitly the grounds on which normative claims are made in society: self-transcendence, adaptation, responsibility, language, strong evaluations, reflexivity and the reproduction of life all meet these two requirements. I sought to recover those sources with the help of which we may then rearticulate a universalistic idea of humanity as something that human beings have themselves created. Only an idea of humanity that results from humans' own properties, and then allows humans to reflect further on themselves as the creators of their own ideas and institutions, can then turned into a normative one: a human is a being who does philosophical anthropology.

To conclude, I just would like to highlight, in more systematic fashion, some of the themes that have accompanied us throughout. 


\section{The Idea of 'Normative Descriptions'}

The tension between descriptive and normative claims has proved central in the development of the social sciences of the past 150 years. Few would deny that their interrelations pose real challenges, but little agreement remains as to what are the best way to tackle them. Given this genuine complexity, positions have tended to privilege or indeed sacrifice one over the other. As part of a programme that seeks to explore key dimensions of the human, the idea of a philosophical sociology offers in this regard the notion of normative descriptions. This was raised most explicitly in Chapters 2, 5, 7 and 8, and is possibly best captured in Hannah Arendt's idea that concentration camps are, literally, 'hell on earth'. Arendt's argument is that there are a number of social phenomena whose adequate description depends upon our ability to grasp its normative dimension. Thus seen, the idea of a normative description coheres around three basic commitments: First, a universalistic principle of humanity that treats all individual human beings as members of the same species on the grounds of the anthropological capacities that they share. Second, a definition of normativity that is explicitly based on the ways in which different practices and institutions promote or indeed undermine the development of our generic human potentials. Third, an approach where the explanatory register of the social sciences reconnects with the normative questions that we commonly associate with the philosophical tradition. Philosophical sociology does not claim that normativity is the centre of social life but contends that social life cannot be fully accounted for without this kind of explicit normative orientation.

\section{The 'Scandal' of the Human Need for an Anthropology}

A notion that we take from Kant, the idea of the scandal of reason has been used to mark a central dilemma in Kant's general anthropology (Chapters 2, 3 and 4). On the one hand, the logical integrity of the categories of understanding, as well as of the categorical imperative of morality itself, points to a claim to universality that is not specifically human. Kant used the idea of pure rational beings in order to highlight the fact that, if reason is to genuinely be able to provide a firm basis for science and morality, then reason cannot be seen as a purely human feature; reason cannot rely on a mere anthropology. On the other hand, Kant was equally aware of the fact that it is human knowledge and action that are in need in orientation; indeed, that the existential need for philosophy is particularly human: for philosophical arguments to work, they have to do so primarily for humans and, to a large extent also, be tailored anthropocentically to human needs. 
But the idea of the scandal of reason refers to an additional challenge in Kant's thought: humans have proved unable to achieve firm, rational knowledge of precisely those areas of life that matter the most to us: transcendental questions about the existence of god and the possibility of life after death and immanent ones about how I am to handle my own free will. Kant thought that although humans do not ask themselves 'what is a human being' with the same intensity that they raise questions about god, immortality and freedom, raising the question about our human properties was just the logical consequence of interrogating about freedom and immortality: the human being then becomes reason's popular edition (Blumenberg 2011: 374). One variant of this argument is that, while the 'what is a human being' question may not often be posed by individuals themselves (with the exception of professional intellectuals who do so in their 'expert' capacity), questions about god, freedom and immortality are key existential questions about the 'meaning of life' in both its transcendental and immanent dimensions. This internal opacity and intractability of human beings for themselves is not restricted to any particular intellectual or even religious tradition. Humans are never satisfied with their own answers to the question what is a human being. But this dissatisfaction is not so much cognitive as it is normative. The urgency of the anthropological question is indeed normative: human beings are a key theme and cause of concern only for humans themselves.

\section{The Relationships between Science and Philosophy}

An argument that was discussed most extensively in Chapters 3, 4, 5 and 8 , the project of a philosophical sociology works within a contemporary context in which philosophical concerns are no longer independent from scientific ones; instead, as posthumanist debates make very clear, they are themselves shaped by the practical and technological success of the natural sciences. This does not mean that philosophical questions are now inevitably of secondary relevance: an important philosophical task that remains is to ask what is the price humans pay for having granted science such a level of cognitive authority and autonomy. More radically, the argument has been made that it is not enough for philosophy to accept that it has indeed lost its position of privilege vis-à-vis scientific knowledge; philosophy must still explain philosophically how the debacle of its own claims to knowledge has actually come about (Blumenberg 2011: 172, 358-71). Indeed, this is at least a partial inversion of a dictum that we find in various versions within the tradition of critical theory: philosophy is to create the conditions for its own dissolution (Marx 
1975), or philosophy is set to carry on while and indeed because it has proved unable to bring about the good society (Adorno 1981).

It is interesting, however, that as the scope of this enquire about the human widened in order to accommodate the different knowledge-claims that orient sociology and philosophy, it also became more apparent that this was itself dependent upon the previous reduction of the legitimacy of theological questions as a legitimate domain of enquiry: all their problems notwithstanding, science and philosophy remain rational and immanent in a way that theology is not (Chapters 4 and 6). But even if we were to leave its dogmatic dimension out of the equation, my reconstruction in this book demonstrates that there is a strictly speculative side of our reflections on the humanity of human: they require us to create, imagine and indeed anticipate ideal notions of the human for which no adequate empirical evidence may ever be given.

At the same time, the very historicity of this quest about our human status in the cosmos has itself proved a transcultural and transhistorical constant (Voegelin 1962): all anthropology is historical in at least this sense. The rise of philosophical anthropology as an attempt to bring together scientific and philosophical knowledge-claims about our shared humanity can then be treated as an epochal marker: human beings have at last become aware of their own normative standing. Its emergence as a legitimate intellectual field is a historical accomplishment that must be renewed and defended because our shared humanity has become increasingly important (but also challenging) for humans themselves. More than a particular discipline or intellectual tradition, philosophical anthropology may then be seen as the constant human project through which humans try to know themselves. The paradigmatic philosophical reference to ideas of reflexivity of this kind is of course that of the oracle of Delphi: know thyself. As a command, self-knowledge is an anthropological theme that arises only when appeals to a divinity have given way to human reason. ${ }^{1}$ It is human reason that triggers a process of objectivation of the world that must lead also to humans' own self-objectivation (Blumenberg 2011: 636). To know oneself means to learn the ways in which culture is able to look after the organic weaknesses of our species: self-knowledge is a fundamental tool in the project of stabilising organic adaptation. But there is also a critical ambivalence that runs through it: self-knowledge as a cognitive proposition does not necessarily lead to self-legislation as a normative claim. But if selfknowledge and self-legislation may turn out to be contradictory, this

${ }^{1}$ If this is the case, then Tönnies (2005) may have been right when he made the point that Delphi's commandment only makes real sense if addressed from the standpoint of humanity as a whole and to humanity as a whole. 
human obsession with looking inwardly runs the risk of becoming selfdefeating or even harmful (Blumenberg 2015).

\section{The Intractability of Human Nature in the Social Sciences}

As we discussed them primarily in Chapters 3,5 and 7, ideas of the social need to be looked at in their own right rather than as a derivation of ideas of agency, the individual or consciousness. To recast the interrelationships between the social and the human has been a central motif of both the socalled linguistic turn and the structure and agency debate that, since the early 1970s, are available in a wide range of contemporary approaches. The proposition that humans are social beings is, to that extent, only another of way of restating the obvious: approaches such as sociobiology are insufficient because the claim that humans replicate, mirror or represent an upgrade on the intrinsically social condition of ants, bees, dolphins or chimpanzees does not even begin to raise the existential aspects of the question what is a human being (Wilson 1978). To the best of our knowledge, these species do not dwell on the scandal of reason.

Reflections on 'the human' are expected to prove their worth by being able to specify what exactly are the properties that define the uniqueness of our species-being. Yet we also know that a substantive definition of the human has proved highly vexatious and that there is no consensual definition of 'human nature' - let alone the human as such. These questions remain contentious because either too much is made of concepts of human nature, in which case the role of social scientific explanations that focus on historical or cultural causes is significantly reduced, or else too little is accepted in terms of the definition of stable anthropological features, in which case social, historical and cultural relativism can be reintroduced through the back door. It has been my contention in this book that ideas of the human are part and parcel of the theoretical tools in contemporary social science - both descriptively and normatively. In order to make this point, a foundational insight of philosophical anthropology remains key: we ought to pay equal attention to the organic and to the intellectual aspects of our humanity - indeed, we have seen in all chapters that they are closely interrelated.

More precisely, Chapter 1 set the scene for the rest of my enquiry as I argued there that the philosophical debate on humanism between Sartre and Heidegger has shaped the two main traditions within which we still engage with ideas of the human. One approach looks at the human from the standpoint of an active agent whose autonomous and efficacious powers define the scope of her contributions to the world, whereas a second strand adopts the view that the most fundamental human trait 
is the fact that we come into a world that, because it pre-exists us, is posed to us as a challenge. Other than Charles Taylor, whose position is indeed ambivalent in this respect and seems to lean towards the second hermeneutical/Heideggerian side, all the writers to whom I have devoted a whole chapter in this book can be seen as belonging to the first Kant/Sartre pole. This does not mean that Heidegger's influence is on the wane, however. Rather the opposite, we have seen in most chapters that writers themselves found the need to counteract, or at least to contend, Heidegger's negative anthropology. Differently put, a book could have been written by looking at the ways in which Heidegger's critique of humanism continues to influence how the humanities and social sciences approach questions about the human. Yet what is specific about this book - and what turns its argument into a critique against this Heideggerian influence - is precisely that it took the shape of an anthropological project. I sought to offer an explicit account of those human properties that allow humans to reflect on their own specificity and worthiness.

\section{The Problem of Anthropocentrism}

Niklas Luhmann (2012) used the idea of a 'humanist prejudice' in order to highlight a particularly sociological version of Gaston Bachelard's general idea of the modern sciences' epistemological obstacles: while positive knowledge of the world - both social and natural - is indeed a human accomplishment, one condition of its objectivity is the realisation that the world itself is not organised around our human needs. At the turn of the twentieth century, Edmund Husserl made a similar argument against those of his pupils who sought to advance philosophical anthropology. Husserl (1931) maintained that science and philosophy are not particularly concerned with the human being because their fundamental questions ought to focus on such general issues as the nature of organic life and the structure of the cosmos, on the scientific side, and reason and intentionality, on the philosophical side. It then ensues that, although both science and philosophy are themselves a particularly sophisticated outcome of human action, they are only possible thanks to a dual act of decentring we mentioned above: first, humans must stop putting themselves at the centre of their explanations about the functioning of the cosmos, culture and society and, second, they must equally accept that there is nothing necessary about their own existence.

Luhmann, Bachelard and Husserl all build here on a more general version of this argument that goes back to fifteenth-century astronomy and theology. The so-called 'Copernican turn' refers to one particular implication of Nicolaus Copernicus's demonstration that the sun rather than planet earth is at the centre of the solar system: the adequacy of 
Copernicus's scientific observations about the orbits of planets is seen as possible because Copernicus stopped worrying about the philosophical and theological implications of the idea that humans are not at the centre of the universe. In its 'scientific' reception, the morale of Copernicus's story is clear: indifference towards the human is the price we pay for the scientific, predictive and explanatory, success of our theories. A price, indeed, he thought it was worth paying for.

Hans Blumenberg offers a different, arguably more historical and philosophical, interpretation of the Copernican turn. In the previous Ptolemaic model, the centrality of the earth's position in the cosmos was never a question in its own right. Ptolemy took the earth's central proposition for granted and denied that our planet was at all an object for astronomy (Blumenberg 1987: 209-16). Copernicus's turn was then not so much to do with the displacement of the earth from the centre of the solar system to the peripheral status of another planet as it was to do with its explicit inclusion within a cosmos of celestial objects; Copernicus's success has to do with the fact that he was able to find a position for the earth within the solar system. Thus seen, far from a rejection of anthropocentrism, Copernicus's real turn entails rather a renewal of the possibility of the 'rational coordination' between man and the cosmos (1987: 224). What humans lose in terms of transcendental certainty they gain in terms of their cognitive ability to make sense of the world that surrounds them: 'the fact that the world was created for man does not guarantee primarily the security of his life, but rather the performance of his reason in relation to the whole ... The senses have lost their Paradise, not reason' (1987: 203). The renewal of the human trust in its own rational powers, that marks the rise of modern times, will now have to be able to compensate for the fact that god is no longer available for advice. The modern predicament is marked, therefore, by what Blumenberg calls the 'ambiguous effect of Copernicanism on human self-consciousness ... it could just as well be the humiliation of losing the central position as the triumph of the reason that penetrated the foreground of appearances' (1987: 81).

Throughout this book, these questions have appeared as the problems of anthropocentrism and humanism and we may once again attempt at their delimitation. Anthropocentrism refers primarily to the subjective perspective that humans cast on the world; it refers to the perspectivism that emerges out of the bodily constitution of the human condition and which then makes humans turn themselves into the standard with which to measure everything that takes place in the world:

Anthropocentrism is not a physical fact but more nearly a kind of juridical state of affairs that not only allows man to preserve his existence with the aid of nature but also certifies the undisputedness of this usufruct ... Above all, the idea of the unchallenged utilization of a pre-existing usefulness excludes an attitude that was 
evidently, if not detected, then suspected as an implication in the pagan formulas of anthropocentrism: the conversion of the right to self-preservation into a claim of right to the world. (1987: 188)

Anthropocentrism ultimately relies on a principle of human authorship whose purpose is to establish the following formula: the human origins of $\mathrm{X}$ equal a right over $\mathrm{X}$. For its part, humanism refers to the normative articulation of the human as a possessor of intrinsic qualities and, above all, dignity. The universalistic principle of humanity that is central to this book is then being pulled in two opposing directions: it must simultaneously affirm the general inclusion of all human beings (and thus favour some form of humanism and anthropocentrism) but then also accept that our very perspectivism as a species shows also the limitations, or at least the dangers, of humanism and anthropocentrism. Evolution does not lead to the human being as its final point and human beings are a contingent principle for everything but themselves. Yet the fact that human beings are not at the centre of the universe does not change the fact that they are at the centre of their own human life. The only consistent form of anthropocentrism is the one that gives an account of itself as a human accomplishment and, in so doing, it reinforces a sense of human dignity: 'the anthropocentrism that affirms and posits itself must be transparent to itself and should not be based on the illusions of the organization of our equipment for experiencing the world, if that anthropocentrism is meant to be constituted as a rational option of consciousness' (1987: 124). The deeper we try to justify social institutions in terms of their anthropological underpinnings - and this argument is present in one way or another in every single Chapter of my book - the less humans are able to reclaim their own centrality in the natural cosmos. At the same time, as the human capacity for instrumental action has expanded to almost no end, the normative implications of anthropocentrism grow ever more untenable. ${ }^{2}$ The more that humans get to know about the natural world, the less they are able to reclaim a strictly anthropological stake in the quest for the meaning of the cosmos: the natural world becomes in fact even more unpredictable, and even also dangerous, for human beings (Blumenberg 2011: 488).

Crises in contemporary society are surely related to the experiences of modernity in the conventional sense in which they are understood: between values and institutions, between good intentions and awful deeds. They are related to success and failures of progress, democracy and capitalism. But they also belong in our perennial inability to accept the difficulties that ensue when human beings gather courage and decide to reflect about themselves.

\footnotetext{
${ }^{2}$ Recent debates on the Anthropocene are a case in point. See Chernilo (2017).
} 


\section{References}

Abbas, A. and McLean, M. (2003) 'Communicative competence and the improvement of university teaching: Insights from the field', British fournal of Sociology of Education 24 (1): 69-82.

Adorno, T. (1981) Negative dialectics, London: Continuum.

(2000) Introduction to sociology, Cambridge: Polity.

(2003) The jargon of authenticity, London: Routledge.

Alexander, J. C. (1983) Theoretical logic in sociology volume 4. The modern reconstruction of classical thought: Talcott Parsons, Berkeley and Los Angeles: University of California Press.

Alexander, J. C., Giesen, B., Münch, R. and Smelser, J. (eds.) (1987) The micromacro link, Los Angeles: University of California Press.

Althusser, L. (1969) For Marx, London: Verso.

(2003) 'The humanist controversy', in Althusser, L. The humanist controversy and other writings, London: Verso.

Alvear, R. (forthcoming) Die Stellung des Menschen in der zeitgenössischen Soziologie. Umrisse zu einer Soziologischen Anthropologie, Ph.D. thesis Flensburg University.

Archer, M. S. (1988) Culture and agency: The place of culture in social theory, Cambridge University Press.

(1991) 'Presidential address. Sociology for one world: Unity and diversity', International Sociology 6 (2): 131-47.

(1995) Realist social theory: The morphogenetic approach, Cambridge University Press.

(2000) Being human: The problem of agency, Cambridge University Press.

(2003) Structure, agency and the internal conversation, Cambridge University Press.

(2007) Making our way through the world: Human reflexivity and social mobility, Cambridge University Press.

(2009) 'El eurocentrismo no muere fácilmente: La sociología más allá del centro y la periferia', in Archer, M. S. Teoría social realista. El enfoque morfogenético, Santiago: Ediciones Universidad Alberto Hurtado.

(2012) The reflexive imperative in late modernity, Cambridge University Press.

Archer, M. S., Bhaskar, R., Collier, A., Lawson, T. and Norrie, A. (eds.) (1998) Critical realism: Essential readings, London: Routledge.

Archer, M. S. and Tritter, J. (eds.) (2000) Rational choice theory: Resisting colonization, London: Routledge. 
Arendt, H. (1953) 'The origins of totalitarianism - A reply', Review of Politics 15 (1): 76-84.

(1976) The origins of totalitarianism, Orlando: Harcourt.

(1978) The life of the mind, New York: Harcourt.

(1992) Lectures on Kant's political philosophy, University of Chicago Press.

(1998) The human condition, University of Chicago Press.

(2005) The promise of politics, New York: Schocken.

(2006) Between past and future, New York: Penguin.

Aron, R. (1967) 18 Lectures on industrial society, London: Weidenfeld \& Nicolson. Aronson, R. (1980) Fean-Paul Sartre - Philosophy in the world, London: Verso.

Atwell, J. (1986) 'Sartre and action theory', in Silverman, H. and Elliston, F. (eds.), Fean-Paul Sartre: Contemporary approaches to his philosophy, Brighton: Harvester Press.

Ayer, A. J. (ed.) (1968) The humanist outlook, London: Pemberton.

Bachelard, G. (2002) The formation of the scientific mind, Manchester: Clinamen.

Badmington, N. (ed.) (2000) Posthumanism, Basingstoke: Palgrave.

Baehr, P. (2002) 'Identifying the unprecedented: Hannah Arendt, totalitarianism, and the critique of sociology', American Sociological Review 67 (6): 804-31.

(2010) Hannah Arendt, totalitarianism and the social sciences, California: Stanford University Press.

(2012) 'Debating totalitarianism: An exchange of letters between Hannah Arendt and Eric Voegelin', History and Theory 51 (3): 364-80.

Baert, P. (2015) The existentialist moment: The rise of Sartre as a public intellectual, Cambridge: Polity.

Barash, J. A. (1998) 'The sense of history: On the political implications of Karl Löwith's concept of secularization', History \& Theory 37 (1): 69-75.

Barber, B. and Gerhardt, U. (eds.) (1999) Agenda for sociology: Classic sources and current uses of Talcott Parsons's work, Baden-Baden: Nomos.

Basaure, M. (2011) 'In the epicenter of politics: Axel Honneth's theory of the struggles for recognition and Luc Boltanski and Laurent Thévenot's moral and political sociology', European fournal of Social Theory 14 (3): 263-81.

Baum, R. (1977) 'Introduction to part IV. Generalized media in action', in Loubser, J., Baum, R., Effrat, A. and Lidz, V. (eds.), Explorations in the general theory in social science: Essays in honour of Talcott Parsons, vol. II, New York: Free Press.

Beaufret, J. (1973a) Dialogue avec Heidegger. Volume 1: Philosophie grecque, Paris: Minuit.

(1973b) Dialogue avec Heidegger. Volume 2: Philosophie moderne, Paris: Minuit.

(1974) Dialogue avec Heidegger. Volume 3: Approche de Heidegger, Paris: Minuit.

(1985) Dialogue avec Heidegger. Volume 4: Le chemin de Heidegger, Paris: Minuit.

Beemer, J. (2006) 'Breaching the theoretical divide: Reassessing the ordinary and everyday in Habermas and Garfinkel', Sociological Theory 24 (1): 81-104.

Bendix, R. (1970) Embattled reason. Essays on social knowledge, New York: Oxford University Press.

Benhabib, S. (1996) The reluctant modernism of Hannah Arendt, London: Sage. 
(2004) 'Reclaiming universalism: Negotiating republican self-determination and cosmopolitan norms', The Tanner lectures on human values, www.tanner lectures.utah.edu/lectures/volume25/benhabib_2005.pdf (last accessed 20 August 2007).

Benton, T. (1977) Philosophical foundations of the three sociologies, London: Routledge \& Kegan Paul.

Birchall, I. (2004) Sartre against Stalinism, New York: Berghahn.

Bissell, O., Traulsen, J. M. and Haugbolle, L. S. (2002) 'An introduction to functionalist sociology: Talcott Parsons' concept of the "sick role", International Fournal of Pharmacy Practice 10 (1): 60-8.

Blackham, H. J. (1961) Six existentialist thinkers, London: Routledge \& Kegan Paul. (1968) Humanism, London: Penguin.

Blumenberg, H. (1983) The legitimacy of the modern age, Cambridge, MA: MIT Press.

(1987) The genesis of the Copernican world, Cambridge, MA: MIT Press.

(2011) Descripción del ser humano, Buenos Aires: FCE.

(2015) The laughter of the Thracian woman: A protohistory of theory, London: Bloomsbury.

Boden, M. A. (1977) Artificial intelligence and natural man, Sussex: Harvester Press.

(2005) 'Escaping from the Chinese room', in Boden M. A. (ed.), The philosophy of artificial intelligence, Oxford University Press.

Boltanski, L. (2011) On critique. A sociology of emancipation, Cambridge: Polity.

(2012) Love and justice and competences, Cambridge: Polity.

(2013) The foetal condition. A sociology of engendering and abortion, Cambridge: Polity.

Boltanski, L. and Thévenot, L. (1999) 'The sociology of critical capacity', European fournal of Social Theory 2 (3): 359-77.

(2006) On justification: Economies of worth, Princeton University Press.

Borradori, G. (ed.) (2003) Philosophy in a time of terror: Dialogues with fürgen Habermas and Facques Derrida, University of Chicago Press.

Borsari, A. (2009) 'Notes on "philosophical anthropology" in Germany". An introduction', Iris. European Fournal of Philosophy and Public Debate 1 (1): 113-29.

Bourdieu, P. (1991) The political ontology of Martin Heidegger, Cambridge: Polity. (1994) Sociology in question, London: Sage.

Braidotti, R. (2013) The posthuman, Cambridge: Polity.

Browne, C. (2014a) "'Experience is a mixture of violence and justification": Luc Boltanski in conversation with Craig Browne', Thesis Eleven 124 (1): 7-19.

(2014b) 'The institution of critique and the critique of institutions', Thesis Eleven 124 (1): 20-52.

Brunkhorst, H. (2014) 'Revolutionary constitutions: Arendt's inversions of Heidegger', European Fournal of Cultural and Political Sociology 1 (3): 283-98.

Burkle, H. (1971) 'Sartre's “ideal” of social unity', in Warnock. M. (ed.), Sartre, New York: Anchor.

Burnham, J. C. (2014) 'Why sociologists abandoned the sick role concept', History of the Human Sciences 27 (1): 70-87. 
Buxton, W. (1985) Talcott Parsons and the capitalist nation-state, University of Toronto Press.

Caetano, A. (2015) 'Defining personal reflexivity: A critical reading of Archer's approach', European fournal of Social Theory 18 (1): 60-75.

Calarco, M. (2008) Zoographies: The question of the animal from Heidegger to Derrida, New York: Columbia University Press.

Camic, C. (1991) 'Introduction: Talcott Parsons before The structure of social action', in Camic, C. (ed.), Talcott Parsons: The early essays, University of Chicago Press.

Caputo, J. (1992) 'Heidegger's scandal: Thinking and the essence of the victim', in Rockmore, T. and Margolis, J. (eds.), The Heidegger case: On philosophy and politics, Philadelphia: Temple University Press.

Cassirer, E. (1972) The philosophy of symbolic forms. Volume 3. The phenomenology of knowledge, New Haven: Yale University Press.

(1996) The philosophy of symbolic forms. Volume 4. The metaphysics of symbolic forms, New Haven: Yale University Press.

(2000) The logic of cultural sciences, New Haven: Yale University Press.

Celikates, R. (2006) 'From critical social theory to a social theory of critique: On the critique of ideology after the pragmatic turn', Constellations 13 (1):21-40.

Chernilo, D. (2002) 'The theorisation of social co-ordinations in differentiated societies. The theory of generalised symbolic media in Parsons, Luhmann and Habermas', British fournal of Sociology 53 (3): 431-49.

(2007a) A social theory of the nation-state: The political forms of modernity beyond methodological nationalism, London: Routledge.

(2007b) 'Universalismo y cosmopolitismo en la teoría de Jürgen Habermas', Estudios Públicos 106: 175-203.

(2009) 'Talcott Parsons' sociology of the nation-state', in Hart, C. (ed.), Collection of essays in honour of Talcott Parsons, Cheshire: Midrash.

(2012a) 'Cosmopolitanism and the question of universalism', in Delanty, G. (ed.), The Routledge handbook of cosmopolitan studies, Abingdon: Routledge.

(2012b) 'Cosmopolitanism in social theory: An ambivalent defence', in Krossa, A. and Robertson, R. (eds.), European cosmopolitanism in question, Basingstoke: Palgrave.

(2012c) 'Social and system integration: The philosophical foundations of a key distinction in (British) social theory', www.academia.edu/2654231/Social_ and_System_Integration_The_Philosophical_Foundations_of_a_Key_Disti nction_in_British_Social_Theory (last accessed August 2016).

(2012d) 'Historia de la sociología y teoría sistemática en Niklas Luhmann', in Cadenas, H., Mascareño, A., and Urquiza, A. (eds.), Niklas Luhmann y el legado universalista de su teoría. Aportes para el análisis de la complejidad social contemporánea, Santiago: RIL.

(2013a) The natural law foundations of modern social theory: A quest for universalism, Cambridge University Press.

(2013b) 'Jürgen Habermas: Modern social theory as postmetaphysical natural law', Fournal of Classical Sociology 13 (2): 254-73.

(2014) 'The idea of philosophical sociology', British fournal of Sociology 65 (2): 338-57. 
(2017) 'the question of the human in the Anthropocene debate', European fournal of Social Theory 20 (1): 44-60.

Clark, A. (2001) Mindware: An introduction to the philosophy of cognitive science, Oxford University Press.

(2003) Natural born cyborgs: Minds, technologies and the future of human intelligence, Oxford University Press.

(2008) Supersizing the mind: Embodiment, action and cognitive extension, Oxford University Press.

Clark, A. and Chalmers, D. (2008) 'The extended mind', in Clark, A. Supersizing the mind: Embodiment, action and cognitive extension, Oxford University Press.

Clark, D. (2007) 'On being "the last Kantian in Nazi Germany": Dwelling with animals after Levinas', in Ham, J. and Senior, M. (eds.), Animal Acts, New York: Routledge.

Cohen, J. and Arato, A. (1992) Civil society and political theory, Cambridge, MA: MIT Press.

Cohen, R. A. (2006) 'Introduction: Humanism and anti-humanism - Levinas, Cassirer, and Heidegger', in Levinas, E. Humanism of the other, Urbana and Chicago: University of Illinois Press.

Cohen-Solal, A. (1991) Sartre - A life, London: Minerva.

Connell, R. (2007) Southern theory, Cambridge: Polity.

Connolly, W. (2004) 'Catholicism and philosophy: A nontheistic appreciation', in Abbey, R. (ed.), Charles Taylor, Cambridge University Press.

(2011) A world of becoming, Durham, NC: Duke University Press.

Cooke, M. (1993) 'Habermas and consensus', European fournal of Philosophy 1 (3): $247-67$.

Cordero, R. (2014a) 'It happens in-between: On the spatial birth of politics in Arendt's On revolution', European fournal of Cultural and Political Sociology 1 (3): 249-65.

(2014b) 'Crisis and critique in Jürgen Habermas's social theory', European Fournal of Social Theory 17(4): 497-515.

Craib, I. (1976) Existentialism and sociology. A study of Fean-Paul Sartre, Cambridge University Press.

Cumming, R. D. (1988) 'This place of violence, obscurity and witchcraft', in Wilcocks, R. (ed.), Critical essays on Fean-Paul Sartre, Boston: G. K. Hall.

Dahrendorf, R. (1958) 'Out of utopia: Towards a reorientation of sociological analysis', American fournal of Sociology 64 (2): 115-27.

(1962) 'Sociology and human nature', in Essays in the theory of society, Stanford University Press.

(1973 [1957]) Homo sociologicus, London: Routledge \& Kegan Paul.

Davies, T. (1997) Humanism, London: Routledge.

de Mul, J. (ed.) (2014) Plessner's philosophical anthropology: Perspectives and prospects, Amsterdam: Amsterdam University Press.

Deleuze, G. and Guattari, F. (1995) What is philosophy?, New York: Columbia University Press.

Depeltau, F. (2008) 'Relational thinking: A critique of co-deterministic theories of structure and agency', Sociological Theory 26 (1): 51-73. 
Derrida, J. (1982) 'The ends of man', in Derrida, J. Margins of philosophy, University of Chicago Press.

(1991a) 'Philosopher's hell: An interview', in Wolin, R. (ed.), The Heidegger controversy: A critical reader, New York: Columbia University Press.

(1991b) Of spirit: Heidegger and the question, University of Chicago Press.

(1997) Cosmopolites de tous les pays, encore un effort!, Galilée: Paris.

(2002) 'Structure, sign and play in the discourse of the human sciences', in Derrida, J. Writing and difference, London: Routledge.

Diken, B. (2015) 'Critique as justification - and beyond', Sociological Review 63 (4): 922-39.

Dreyfus, H. L. (2004) 'Taylor's (anti-)epistemology', in Abbey, R. (ed.), Charles Taylor, Cambridge University Press.

Dreyfus, H. L. and Dreyfus, S. E. (2005) 'Making mind versus modelling the brain: Artificial intelligence back at a branch-point', in Boden, M. A. (ed.), The philosophy of artificial intelligence, Oxford University Press.

Durkheim, E. (1960) 'The dualism of human nature and its social conditions', in K. Wolf (ed.), Essays on sociology and philosophy, New York: Harper.

(1970) Montesquieu and Rousseau. Forerunners of sociology, Michigan: Ann Arbor.

(1982) The rules of sociological method, New York: Free Press.

(1992) Professional ethics and civic morals, London and New York: Routledge \& Kegan Paul.

Durkin, K. (2014) The radical humanism of Erich Fromm, Basingstoke: Palgrave Macmillan.

Dux, G. (1991) 'Communicative reason and interest: On the reconstruction of the normative order in societies structured by egalitarianism or domination', in Honneth, A. and Joas, H. (eds.), Essays on Fürgen Habermas's theory of communicative action, Cambridge, MA: MIT Press.

Dworkin, R. (2008) Fustice in robes, Boston: Harvard University Press.

Elder-Vass, D. (2007) 'Reconciling Archer and Bourdieu in an emergentist theory of action', Sociological Theory 25 (4): 325-46.

(2010) The causal powers of social structures: Emergence, structure and agency, Cambridge University Press.

Elkarïn-Sartre, A. (2007) 'Preface to the 1996 French edition', in Sartre, M. Existentialism is a humanism, New Haven: Yale University Press.

Eysenck, H. J. (1968) 'Humanism and the future', in Ayer, A. J. (ed.), The humanist outlook, London: Pemberton.

Farías, V. (1989) Heidegger and Nazism, Philadelphia: Temple University Press.

Faye, E. (2009) Heidegger. The introduction of Nazism into philosophy, New Haven: Yale University Press.

Feher, F. (1991a) 'Weber and the rationalization of music', in Heller, A. and Feher, F. The grandeur and twilight of radical universalism, New Jersey: Transaction.

(1991b) 'Between relativism and fundamentalism: Hermeneutics as Europe's mainstream political and moral tradition', in Heller, A. and Feher, F. The grandeur and twilight of radical universalism, New Jersey: Transaction.

Ferrara, A. (1987) 'A critique of Habermas's consensus theory of truth', Philosophy and Social Criticism 13 (1): 39-67. 
Fine, R. (2008) 'Judgment and the reification of the faculties. A reconstructive reading of Arendt's Life of the mind', Philosophy and Social Criticism 34 (1-2): 157-76.

(2014) 'Re-reading Arendt's On revolution: On the dialectics of the modern revolutionary tradition', European fournal of Cultural and Political Sociology 1 (3): 219-33.

Finkielkraut, A. (2001) In the name of humanity: Reflections on the twentieth century, London: Pimlico.

Fischer, J. (2009) 'Exploring the core identity of philosophical anthropology through the works of Max Scheler, Helmuth Plessner and Arnold Gehlen', Iris. European Fournal of Philosophy and Public Debate 1 (1): 153-70.

Flynn, T. R. (1988) 'L'imagination au pouvoir: The evolution of Sartre's political and social thought', in Wilcocks, R. (ed.), Boston: G. K. Hall.

Foucault, M. (1997) The order of things, London: Routledge.

Fowler, B. (2015) 'Figures of descent from classical sociological theory: Luc Boltanski', in Susen, S. and Turner, B. (eds.), The spirit of Luc Boltanski, London: Anthem.

Frank, A. (2013) 'From sick role to practices of health and illness', Medical Education 47: 18-25.

Fuller, S. (2011) Humanity 2.0: What it means to be human past, present and future, Basingstoke: Palgrave Macmillan.

Fuller, S. and Lipinska, V. (2014) The proactionary imperative. A foundation for transhumanism, Basingstoke: Palgrave Macmillan.

Gadamer, H.-G. (1989) Truth and method, London: Sheed and Ward.

(1992) 'The political incompetence of philosophy', in Rockmore, T. and Margolis, J. (eds.), The Heidegger case: On philosophy and politics, Philadelphia: Temple University Press.

Gangas, S. (2014) 'From alienation to capability deprivation: Reconstructing a sociological concept', Social Science Information 53 (1): 54-75.

(2016) 'From agency to capabilities: Sen and sociological theory', Current Sociology 64 (1): 22-40.

Gebauer, G. and Wulf, C. (2009) 'After the "death of man": From philosophical anthropology to historical anthropology', Iris. European fournal of Philosophy and Public Debate 1 (1): 171-86.

Gehlen, A. (1980) Man in the age of technology, New York: Columbia University Press.

(1988) Man: His nature and his place in the world, New York: Columbia University Press.

Gerhardt, U. (1989) Ideas about illness: An intellectual and political history of medical sociology, London: Macmillan.

(ed.) (1993) Talcott Parsons on National Socialism, New York: Aldine de Gruyter.

(1999) 'National Socialism and the politics of The structure of social action', in Barber, B. and Gerhardt, U. (eds.), Agenda for sociology: Classic sources and current uses of Talcott Parsons's work, Baden-Baden: Nomos.

(2002) Talcott Parsons. An intellectual biography, Cambridge University Press.

Giddens A. (2003) Capitalism and modern social theory, Cambridge: Polity. 
Ginsberg, M. (1968) Essays in sociology and social philosophy, London: Penguin.

Gordon, P. (2012) Continental divide. Heidegger, Cassirer, Davos, Cambridge, MA: Harvard University Press.

Gouldner, A. W. (1965) Enter Plato. Classical Greece and the origins of social theory, London: Routledge \& Kegan Paul.

(1973) The coming crisis of Western sociology, London: Heinemann.

Grassi, E. (1983) Heidegger and the question of Renaissance humanism, State University of New York Press.

(1988) 'The rehabilitation of rhetorical humanism regarding Heidegger's antihumanism', Diogenes 36 (142) 136-56.

Gronow, A. (2008) 'The over- or the undersocialized conception of man? Practice theory and the problem of intersubjectivity', Sociology 42 (2): 243-59.

Guggenheim, M. and Potthast, J. (2012) 'Symmetrical twins: On the relationship between actor-network theory and the sociology of critical capacities', European Fournal of Social Theory 15 (2): 157-78.

Haar, M. (1980) 'Sartre and Heidegger', in Silverman, H. and Elliston, F. (eds.), fean-Paul Sartre: Contemporary approaches to his philosophy, Brighton: Harvester Press.

(1993) Heidegger and the essence of man, State University of New York Press.

Habermas, J. (1971) 'Science and technology as ideology', in Habermas, J. Towards a rational society, Boston: Beacon Press.

(1972) Knowledge and human interest, London: Heinemann.

(1974) Theory and practice, London: Heinemann.

(1976) 'Some distinctions in universal pragmatics. A working paper', Theory and Society 3(2): 155-67.

(1979) 'What is universal pragmatics?', in Habermas, J. Communication and the evolution of society, Cambridge: Polity.

(1984a) The theory of communicative action. Volume 1: Reason and the rationalization of society, London: Heinemann.

(1984b) 'Notizen sur Entwicklung der Interaktionskompetenz', in Habermas, J. Vorstudien und Ergänzungen zur Theorie des kommunikativen Handelns, Frankfurt: Suhrkamp.

(1985) Philosophical-political profiles, Cambridge, MA: MIT Press.

(1987) The theory of communicative action. Volume 2: The critique of functionalist reason, Boston: Beacon Press.

(1988) On the logic of the social sciences, Cambridge, MA: MIT Press.

(1989) 'Notas sobre el desarrollo de la competencia interactiva', in Habermas, J. Teoría de la acción comunicativa: Complementos y estudios previos, Madrid: Cátedra.

(1990a) Moral consciousness and communicative action, Cambridge: Polity.

(1990b) The philosophical discourse of modernity, Cambridge: Polity.

(1991a) 'Martin Heidegger: On the publication of the lectures of 1935', in Wolin, R. (ed.), The Heidegger controversy. A critical reader, New York: Columbia University Press.

(1991b) 'Is intentionality more basic than linguistic meaning?', in Lepore, E. and van Gulick, R. (eds.), Fohn Searle and his critics, Oxford: Blackwell. (1992a) Postmetaphysical thinking, Cambridge: Polity. 
(1992b) 'Work and Weltanschauung: The Heidegger controversy from a German perspective', in Habermas, J. The new conservatism: Cultural criticism and the historians' debate, Cambridge, MA: MIT Press.

(1995) 'Reconciliation through the public use of reason: Remarks on John Rawls's political liberalism', fournal of Philosophy 92 (3): 109-31.

(1996) Between facts and norms, Cambridge, MA: MIT Press.

(2001) On the pragmatics of social interaction, Cambridge: Polity.

(2002) On the pragmatics of communication, Cambridge: Polity.

(2003a) Truth and justification, Cambridge, MA: MIT Press.

(2003b) The future of human nature, Cambridge: Polity.

(2008) Between naturalism and religion, Cambridge: Polity.

(2010) 'The concept of human dignity and the realistic utopia of human rights', Metaphilosophy 41 (4): 464-80.

Habermas, J. and Luhmann, N. (1971) Theorie der Gesellschaft oder Sozialtechnologie, Frankfurt: Suhrkamp.

Haraway, D. (1991) Simians, cyborgs and women: The reinvention of nature, London: Free Association Books.

(2008) When species meet, Minneapolis: University of Minnesota Press.

Hayim, G. (1992) 'Naturalism and the crisis of rationalism in Habermas', Social Theory and Practice 18 (2): 182-209.

Hayles, K. N. (1999) How we became posthuman: Virtual bodies, cybernetics, literature and informatics, University of Chicago Press.

Hayman, R. (1986) Writing against: A biography of Sartre, London: Weidenfeld \& Nicolson.

Hawkins, S. (2015) 'Afterword: Reading into the distance', in Blumenberg, H. The laughter of the Thracian woman: A protohistory of theory, London: Bloomsbury.

Hegel, G. (1975) Natural law, Philadelphia: University of Pennsylvania Press.

Heidegger, M. (1991a) 'The self-assertion of the German university', in Wolin, R. (ed.), The Heidegger controversy: A critical reader, New York: Columbia University Press.

(1991b) "“Only a god can save us": Der Spiegel's interview with Martin Heidegger', in Wolin, R. (ed.), The Heidegger controversy: A critical reader, New York: Columbia University Press.

(1993a) 'Letter on humanism', in Heidegger, M., Basic writings, London: Routledge.

(1993b) 'The question concerning technology', in Heidegger, M. Basic writings, London: Routledge.

(1997) Being and time, Oxford: Blackwell.

(2004) What is called thinking?, New York: Harper Collins.

(2005) The essence of human freedom, London: Continuum.

Heinze, M. (2009) 'Helmut Plessner's philosophical anthropology', Philosophy, Psychiatry, E Psychology, 16 (2): 117-28.

Heller, A. (1991a) 'Can poetry be written after the Holocaust?, in Heller, A. and Feher, F. The grandeur and twilight of radical universalism, New Jersey: Transaction.

(1991b) 'Hannah Arendt on the "vita contemplativa", in Heller, A. and Feher, F. The grandeur and twilight of radical universalism, New Jersey: Transaction. 
(1991c) 'With Castoriadis to Aristotle; from Aristotle to Kant; from Kant to us', in Heller, A. and Feher, F. The grandeur and twilight of radical universalism, New Jersey: Transaction.

Hochstrasser, T. (2000) Natural law theories in the early enlightenment, Cambridge University Press.

Höffe, O. (1995) 'Kantian scepticism toward transcendental ethics of communication', in Benhabib, S. and Dallmayr, F. (eds.), The communicative ethics controversy, Cambridge, MA: MIT Press.

Hollis, M. (1977) Models of man. Philosophical thoughts on human action, Cambridge University Press.

Honneth, A. (2005) The struggle for recognition. The moral grammar of social conficts, Cambridge: Polity.

(2009) 'Problems of ethical pluralism: Arnold Gehlen's anthropological ethics', Iris. European Fournal of Philosophy and Public Debate 1 (1): 187-94.

(2010) 'Dissolutions of the social: On the social theory of Luc Boltanski and Laurent Thévenot', Constellations 17 (3): 376-89.

Honneth, A. and Joas, H. (1988) Social action and human nature, Cambridge University Press.

Hughes, H. S. (1974) Consciousness and society, Frogmore: Paladin.

Husserl, E. (1931) 'Phenomenology and anthropology', http://religiousstudies.s tanford.edu/wp-content/uploads/15-1931-PHENOMENOLOGY-AND-A NTHROPOLOGY.pdf (last accessed 19 October 2016).

(1970) The crisis of European sciences and transcendental phenomenology, Evanston: Northwestern University Press.

Ingram, D. (1993) 'The limits and possibilities of communicative ethics for democratic theory', Political Theory 21 (2): 294-321.

Ishiguro, H. (1971) 'Imagination', in Warnock. M. (ed.), Sartre, New York: Anchor.

Janicaud, D. (1996) The shadow of that thought, Evanston: Northwestern University Press.

Jaspers, K. (2000) The question of German guilt, New York: Fordham University Press.

Joas, H. (1991) 'The unhappy marriage of hermeneutics and functionalism', in Honneth, A. and Joas, H. (eds.), Essays on Fürgen Habermas's theory of communicative action, Cambridge, MA: MIT Press.

(2000) The genesis of values, Cambridge: Polity.

(2013) The sacredness of the person: A new genealogy of human rights, Washington, DC: Georgetown University Press.

Jonas, H. (1963) The Gnostic religion: The message of the alien god and the beginnings of Christianity, Boston: Beacon Press.

(1980a) 'Technology and responsibility: Reflections on the new tasks of ethics', in Jonas, H. Philosophical essays: From ancient creed to technological man, University of Chicago Press.

(1980b) 'Biological foundations of individuality', in Jonas, H. Philosophical essays: From ancient creed to technological man, University of Chicago Press.

(1984) The imperative of responsibility: In search of an ethics for the technological age, University of Chicago Press. 
(1996) Mortality and morality: A search for the good after Auschwitz, Evanston: Northwestern University Press.

(2001) The phenomenon of life: Towards a philosophical biology, Evanston: Northwestern University Press.

(2008) Memoirs, Waltham, MA: Brandeis University Press.

Kant, I. (1999) Political writings, Cambridge University Press.

Keefe, T. (1988) 'Sartre's L'Existentialism est un humanisme', in Wilcocks, R. (ed.), Critical essays on Fean-Paul Sartre, Boston: G. K. Hall.

Kelly, M. (1988) 'The Gadamer/Habermas debate revisited: The question of ethics', Philosophy and Social Criticism 14 (3-4): 369-89.

Kerr, F. (2004) 'The self and the good: Taylor's moral ontology', in Abbey, R. (ed.), Charles Taylor, Cambridge University Press.

Kertész, I. (2006) Fateless, London: Vintage.

King, A. (1999) 'Against structure: A critique of morphogenetic social theory', Sociological Review 47 (2): 199-227.

Kisiel, T. (1992) 'Heidegger's apology: Biography as philosophy and ideology', in Rockmore, T. and Margolis, J. (eds.), The Heidegger case: On philosophy and politics, Philadelphia: Temple University Press.

Kleinberg, E. (2003) Generation existential: Heidegger's philosophy in France 19271961, Ithaca: Cornell University Press.

Klemperer, V. (2013) The language of the third Reich, London: Bloomsbury.

Krüger, H.-P. (1991) 'Communicative action or the mode of communication for society as a whole', in Honneth, A. and Joas, H. (eds.), Essays on fürgen Habermas's theory of communicative action, Cambridge, MA: MIT Press.

Kurtz, P. (ed.) (1973) The humanist alternative: Some definitions of humanism, London: Prometheus.

Lafarge, R. (1970) Fean-Paul Sartre: His philosophy, Dublin: Gill \& Macmillan.

Lafont, C. (1999) The linguistic turn in hermeneutic philosophy, Cambridge, MA: MIT Press.

(2004) 'Moral objectivity and reasonable agreement: Can realism be reconciled with constructivism?', Ratio furis 17 (1): 27-51.

Laitinen, A. (2008) Strong evaluations without moral sources: On Charles Taylor's philosophical anthropology and ethics, Berlin: Walter de Gruyter.

Latour, B. (1993) We have never been moderns, Cambridge, MA: Harvard University Press.

(2004) 'Whose cosmos, which cosmopolitics? Comments on the peace terms of Ulrich Beck', Common Knowledge 10 (3): 450-462.

(2013) An enquiry into modes of existence: An anthropology of the moderns, Cambridge, MA: Harvard University Press.

Lazier, B. (2003) 'Overcoming Gnosticism: Hans Jonas, Hans Blumenberg and the legitimacy of the natural world', Fournal of the History of Ideas 64 (4): 619-37.

Levinas, E. (1990a) 'Heidegger, Gagarin and us', in Levinas, E. Difficult freedom: Essays on Fudaism, Baltimore, MD: Johns Hopkins University Press.

(1990b) 'The name of a dog, or natural rights', in Levinas, E. Difficult freedom: Essays on Fudaism, Baltimore, MD: Johns Hopkins University Press. 
(2006) Humanism of the other, Urbana and Chicago: University of Illinois Press.

Levine, D. (1995) Visions of the sociological tradition, University of Chicago Press. Levi-Strauss, C. (1970) The savage mind, University of Chicago Press.

Levy, N. (2002) Sartre, Oxford: Oneworld.

Lockwood, D. (1992) 'Social integration and system integration', in Lockwood, D. Solidarity and schism: The problem of disorder in Durkheimian and Marxist sociology, Oxford: Clarendon Press.

Loewe, D. (2015) 'Justicia contractual y los seres del futuro', in Figueroa, M. (ed.), Liberalismo Político, Santiago: Ril.

Losurdo, D. (1992) 'Heidegger and Hitler's war', in Rockmore, T. and Margolis, J. (eds.), The Heidegger case: On philosophy and politics, Philadelphia: Temple University Press.

Löwith, K. (1964) Meaning in history, University of Chicago Press.

(1970) 'The nature of man and the world of nature for Heidegger's 80th birthday', Southern fournal of Philosophy, 8 (4): 309-18.

(1991) 'The political implications of Heidegger's existentialism', in Wolin, R. (ed.), The Heidegger controversy: A critical reader, New York: Columbia University Press.

(1993) Max Weber and Karl Marx, London: Routledge.

(1995) Heidegger and European nihilism, New York: Columbia University Press.

Luhmann, N. (1977) 'Generalized media and the problem of contingency', in Loubser, J., Baum, R., Effrat A., and Lidz, V. (eds.), Explorations in the general theory in social science: Essays in honor of Talcott Parsons, New York: Free Press.

(1994) "'What is the case?" and "what lies behind it?" The two sociologies and the theory of society', Sociological Theory 12(2): 126-39.

(1995) Social systems, Stanford University Press.

(2012) The society of society, volume 1, Stanford University Press.

Lyotard, J.-F. (1990) Heidegger and "the fews", Minneapolis: University of Minnesota Press.

(1993) The inhuman, Cambridge: Polity.

McCarthy, T. (1973) 'A theory of communicative competence', Philosophy of the Social Sciences 3 (1): 135-56.

(1979) 'Translator's introduction', in Habermas, J. Communication and the evolution of society, Boston: Beacon Press.

(1985) The critical theory of fürgen Habermas, Cambridge, MA: MIT Press.

MacIntyre, A. (2007) After Virtue, London: Duckworth.

Macpherson, C. B. (1964) The political theory of possessive individualism: Hobbes to Locke, Oxford University Press.

Mairet, P. (1979) 'Introduction', in Sartre, F.-P.: Existentialism and humanism, London: Methuen.

Manent, P. (1998) The city of man, Princeton University Press.

Marcuse, H. (1973) Reason and revolution: Hegel and the rise of social theory, London: Routledge \& Kegan Paul. 
Marino, G. (ed.) (2004) Basic writings of existentialism, New York: Modern Library.

Marquard, O. (1989) Farewell to matters of principle: Philosophical studies, Oxford University Press.

Marx, K. (1973) Grundrisse, London: Penguin.

(1975) Early writings, London: Penguin.

Mascareño, A. (2008) 'Acción, estructura y emergencia en la teoría sociológica', Revista de Sociología 22: 217-56.

(2012) 'Contingencia como unided la diferencia moderna', in Cadenas, H., Mascareño, A. and Urquiza, A. (eds.), Niklas Luhmann y el legado universalista de su teoría: Aportes para el análisis de la complejidad social contemporánea, Santiago: RIL.

Mascareño, A. and Chernilo, D. (2009) 'Obstacles and perspectives of Latin American sociology: Normative universalism and functional differentiation', Soziale Systeme 15 (1): 72-96.

Matustik, M. (1989) 'Habermas on communicative reason and performative contradiction', New German Critique 47 (spring-summer): 143-72.

Mehring, R. (2014) Carl Schmitt: A biography, Cambridge: Polity.

Mendelson, J. (1979) 'The Habermas-Gadamer debate', New German Critique 18 (autumn): 44-73.

Menzies, K. (1977) Talcott Parsons and the social image of man, London: Routledge \& Kegan Paul.

Merleau-Ponty, M. (1964) Sense and non-sense, Evanston: Northwestern University Press.

(1969) Humanism and terror: An essay on the communist problem, Boston: Beacon.

Merton, R. (1964) Social theory and social structure, New York: Free Press.

Mills, C. W. (1961) The sociological imagination, New York: Grove.

Miranda, P. (2012) La precompresión de lo humano en la sociología de Luhmann: Raíces antropológicas del antihumanismo teórico luhmanniano, Santiago: Ediciones Universidad Alberto Hurtado.

Misgeld, D. (1977) 'Discourse and conversation: The theory of communicative competence and hermeneutics in the light of the debate between Habermas and Gadamer', Philosophy and Social Criticism 4 (4): 321-44.

Mitcham, C. (2010) 'Philosophical biology and environmentalism', in TiroshSamuelson, H. and Wiese, C. (eds.), The legacy of Hans Fonas: Fudaism and the phenomenon of life, Leiden: Brill.

Moon, J. D. (1995) 'Practical discourse and communicative ethics', in White, S. K. (ed.), The Cambridge companion to Habermas, Cambridge University Press.

Mouzelis, N. (1974) 'Social and system integration: some reflections on a fundamental distinction', British fournal of Sociology 25 (4): 395-409.

(1992) 'Social and system integration: Habermas' view, British fournal of Sociology 43 (2): 267-88.

(1995) Sociological theory: What went wrong?, London: Routledge.

(1999) 'Modernity: A non-European conceptualization', British fournal of Sociology 50 (1): 141-59. 
Münch, R. (1987) Theory of action: Towards a new synthesis going beyond Parsons, London: Routledge \& Kegan Paul.

Murdoch, I. (1976) Sartre: Romantic rationalist, Glasgow: Fontana.

Nisbet, R. (1967) The sociological tradition, London: Heinemann.

Norris, C. (1987) Derrida, London: Fontana.

Nussbaum, M. (1992) 'Human functioning and social justice: In defense of Aristotelian essentialism', Political Theory 20 (2): 202-46.

(2006) Frontiers of justice: Disability, nationality, species membership, Cambridge, MA: Harvard University Press.

Owens, R. B. (2010) 'Producing Parsons' reputation: Early critiques of Talcott Parsons' social theory and the making of a caricature', Fournal of the History of Behavioral Sciences 46 (2): 165-88.

Papastephanou, M. (1997) 'Communicative action and philosophical foundationalism: Comments on the Apel-Habermas debate', Philosophy and Social Criticism 23 (4): 41-69.

Parsons, T. (1937) The structure of social action: A study in social theory with special reference to a group of recent European writers, New York: McGrawHill.

(1953) Working papers in the theory of action, New York: Free Press.

(1961) 'An outline of the social system', in Parsons, T., Shills, E., Naegele, K. and Pitts, J. (eds.), Theories of society, New York: Free Press.

(1964a) 'Evolutionary universals in society', American Sociological Review 29 (3): 339-57.

(1964b) Social structure and personality, New York: Free Press.

(1966) Societies: Evolutionary and comparative perspectives, Englewood Cliffs: Prentice-Hall.

(1967a) 'Some comments on the sociology of Karl Marx', in Parsons, T. Sociological theory and modern society, New York: Free Press.

(1967b) 'Full citizenship for the Negro American?', in Parsons, T. Sociological theory and modern society, New York: Free Press.

(1967c) 'Polarization of the world and international order', in Parsons, T. Sociological theory and modern society, New York: Free Press.

(1967d) 'On the concept of political power', in Parsons, T. Sociological theory and modern society, New York: Free Press.

(1967e) 'On the concept of influence', in Parsons, T. Sociological theory and modern society, New York: Free Press.

(1969a) 'Order and community in the international social system' in Parsons, T. Politics and social structure, New York: Free Press.

(1969b) 'On the concept of value-commitments' in Parsons, T. Politics and social structure, New York: Free Press.

(1970) The social system, London: Routledge \& Kegan Paul.

(1971) The system of modern societies, Englewood Cliffs: Prentice-Hall.

(1977) Social systems and the evolution of action theory, New York: Free Press.

(1978) Action theory and the human condition, New York: Free Press.

Parsons, T. and Platt, J. (1973) The American university, New York: Free Press. 
Parsons, T. and Smelser, N. (1956) Economy and society, London and New York: Routledge \& Kegan Paul/Free Press.

Pedersen, J. (2008) 'Habermas' method: Rational reconstruction', Philosophy of the social sciences 38 (4): 457-85.

Piiroinen, T. (2014) 'For "central conflation": A critique of Archerian dualism', Sociological Theory 32 (2): 79-99.

Plessner, H. (1970) Laughing and crying: A study of the limits of human behavior, Evanston: Northwestern University Press.

Pöggeler, O. (1991) 'Heidegger's political self-understanding', in Wolin, R. (ed.), The Heidegger controversy: A critical reader, New York: Columbia University Press.

Rabinbach, (2000) In the shadow of catastrophe. German intellectuals between apocalypse and enlightenment, Berkeley and Los Angeles: University of California Press.

Rawls, J. (1995) 'Political liberalism: A reply to Habermas', Fournal of Philosophy 92 (3): 132-80.

(1999a) A theory of justice, Oxford University Press.

(1999b) 'Kantian constructivism in moral theory', in Freeman, S. (ed.), Fohn Rawls: Collected papers, Cambridge, MA: Harvard University Press.

Rehberg, K.-S. (2009) 'Philosophical anthropology from the end of World War I to the 1940s and in a current perspective', Iris. European fournal of Philosophy and Public Debate 1 (1): 131-52.

Ritzer, G. (1988) 'Sociological metatheory: A defense of a subfield by a delineation of its parameters', Sociological Theory 6(2): 187-200.

Rocher, G. (1974) Talcott Parsons and American sociology, London: Thomas Nelson and Sons.

Rockmore, T. (1992) 'Heidegger's French connection and the emperor's new clothes', in Rockmore, T. and Margolis, J. (eds.), The Heidegger case: On philosophy and politics, Philadelphia: Temple University Press.

(1995) Heidegger and French philosophy: Humanism, antihumanism and being, London: Routledge.

(2009) 'Foreword to the English edition', in Faye, E. Heidegger: The introduction of Nazism into philosophy, New Haven: Yale University Press.

Rorty, R. (1994) 'Taylor on truth', in Tully, J. (ed.), Philosophy in the age of pluralism, Cambridge University Press.

Rose, H. (1995) 'Goods and life-forms. Relativism in Charles Taylor's political philosophy', Radical Philosophy 071 (May/June): 20-6.

(1998) 'On defining the good life: liberal freedom and capitalist necessity', Constellations 5 (2): 201-14.

Rosa, G. (1995) Love's work, London: Chatto \& Windus.

(2009) Hegel contra sociology, London: Verso.

Safranski, R. (1998) Martin Heidegger: Between good and evil, Cambridge, MA: Harvard University Press.

Sage, D. (2014) How outer space made America: Geography, organization and the cosmic sublime, Farnham: Ashgate.

Said, E. (2004) Humanism and democratic criticism, Basingstoke: Palgrave Macmillan. Sartre, J.-P. (1957) Being and nothingness, Methuen: London. 
(1968) 'Genocide', New Left Review 48: 13-25.

(1978) What is literature?, London: Methuen.

(1995) Anti-Semite and few, New York: Schocken.

(2007) Existentialism is a humanism, New Haven: Yale University Press.

Sayer, A. (2011) Why things matter to people: Social science, values and ethical life, Cambridge University Press.

Scheler, M. (2009) The human place in the cosmos, Evanston: Northwestern University Press.

Schelsky, H. (1967). El hombre en la civilización cientifica y otros ensayos. Buenos Aires: Sur.

Schilling, C. (2002) 'Culture, the "sick role" and the consumption of health', British Fournal of Sociology, 53 (4): 621-638.

Schlossberger, M. (2014) 'Habermas's new turn towards Plessner's philosophical anthropology', in de Mul, J. (ed.), Plessner's philosophical anthropology, Amsterdam University Press.

Schnädelbach, H. (1984) Philosophy in Germany 1831-1933, Cambridge University Press.

(1991) 'The transformation of critical theory', in Honneth, A. and Joas, H. (eds.), Essays on Fürgen Habermas's theory of communicative action, Cambridge, MA: MIT Press.

Schneewind, J. (1998) The invention of autonomy: A history of modern moral philosophy, Cambridge University Press.

Searle, J. R. (2005) 'Minds, brains and programs', in Boden, M. A. (ed.), The philosophy of artificial intelligence, Oxford University Press.

Seemann, A. (2004) 'Lifeworld, discourse and realism: On Jürgen Habermas's theory of truth', Philosophy and Social Criticism 30 (4): 503-14.

Sen, A. (1999) Development as freedom, Oxford University Press.

Sheehan, T. (1993) 'A normal Nazi', New York Review of Books 40 (1-2), www.nybooks.com/articles/1993/01/14/a-normal-nazi (last accessed August 2106).

Simmel, G. (1949) 'The sociology of sociability', American foumal of Sociology 55 (3): 254-61.

(1950) 'Fundamental problems of sociology (individual and society)', in Wolf, K. (ed.), The sociology of Georg Simmel, Glencoe, IL: Free Press.

Sloterdijk, P. (2009) 'Rules for the human zoo: A response to the letter on humanism', Environment and Planning D: Society and Space 27: 12-28.

Sluga, H. (1993) Heidegger's crisis. Philosophy and politics in Nazi Germany, Cambridge, Massachusetts: Harvard University Press.

Smith, A. (2009) The theory of moral sentiments, London: Penguin.

Smith, N. (2002) Charles Taylor: Meaning, morals and modernity, Cambridge: Polity.

(2004) 'Taylor and the hermeneutic tradition', in Abbey, R. (ed.), Charles Taylor, Cambridge University Press.

Soper, K. (1986) Humanism and anti-humanism, La Salle, IL: Open Court.

Stichweh, R. (2008) 'Strangers, inclusions and identities', Santiago. [lecture delivered on the doctoral programme at University Alberto Hurtado]

Stones, R. (2005) Structuration theory, Basingstoke: Palgrave.

Strauss, L. (1974) Natural right and history, University of Chicago Press. 
(2004) 'Restatement on Xenophon's Hiero', in Emberley, P. and Cooper, B. (eds.), Faith and political philosophy: The correspondence between Leo Strauss and Eric Voegelin, 1934-1964, Columbia: University of Missouri Press.

Susen, S. (2015) 'Towards a dialogue between Pierre Bourdieu's "critical sociology" and Luc Boltanski's "pragmatic sociology of critique"', in Susen, S. and Turner, B. (eds.), The spirit of Luc Boltanski, London: Anthem.

Susen, S. and Turner, B. (eds.) (2015) The spirit of Luc Boltanski, London: Anthem.

Taylor, C. (1985a) Human agency and language: Philosophical papers 1, Cambridge University Press.

(1985b) Philosophy and the human sciences: Philosophical papers 2, Cambridge University Press.

(1989) Sources of the self: The making of modern identity, Cambridge, MA: Harvard University Press.

(1991a) 'Language and society', in Honneth, A. and Joas, H. (eds.), Essays on fürgen Habermas's theory of communicative action, Cambridge, MA: MIT Press.

(1991b) The ethics of authenticity, Cambridge, MA: Harvard University Press. (1994) 'The politics of recognition', in Gutmann, A. (ed.), Multiculturalism: Examining the ethics of recognition, Princeton University Press.

(1995a) Philosophical arguments, Cambridge, MA: Harvard University Press.

(1995b) Hegel, Cambridge University Press.

(2007) Modern social imaginaries, Durham and London: Duke University Press.

Tchir, T. (2011) 'Daimon appearances and the Heideggerian influence in Arendt's account of political action', in Yeatman, A., Hansen, P., Zolkos, M. and Barbour, C. (eds.), Action and appearance: Ethics and the politics of writing in Hannah Arendt, London: Continuum.

Theunissen, M. (1985) The other: Studies in the social ontology of Husserl, Sartre, Heidegger and Buber, Cambridge, MA: MIT Press.

Thody, P. (1971) Sartre: A biographical introduction, London: Studio Vista.

Tillich, P. (1964) The courage to be, London: Fontana.

Timmermans, S. and Haas, S. (2008) 'Towards a sociology of disease', Sociology of Health and Illness 30 (5): 659-76.

Toby, J. (1977) 'Parsons' theory of societal evolution', in Parsons, T. The evolution of modern societies, New Jersey: Prentice-Hall.

Tönnies, F. (2005) 'Ways and goals of sociology', in Adair-Toteff, C. (ed.), Sociological beginnings: The first conference of the German society for sociology, Liverpool University Press.

Treviño, A. J. (ed.) (2001) Talcott Parsons today, New York: Rowman \& Littlefield.

Turing A. (2005) 'Computing machinery and intelligence', in Boden, M. A. (ed.), The philosophy of artificial intelligence, Oxford University Press.

Vandenberghe, F. (2005) 'The Archers. A tale of folk (final episode?)', European fournal of Social Theory 8 (2): 227-37.

Varul, M. Z. (2010) 'Talcott Parsons, the sick role and chronic illness', Body and Society 16 (2): 72-94.

Voegelin, E. (1962) 'World-empire and the unity of mankind', International Affairs 38 (2): 170-88. 
(1999) 'Hitler and the Germans', in The collected works of Eric Voegelin, volume 31, Columbia: University of Missouri Press.

(2000) 'The new science of politics', in The collected works of Eric Voegelin, volume 5, Columbia: University of Missouri Press.

Vogel, L. (2001) 'Foreword', in Jonas, J. The phenomenon of life. Towards a philosophical biology, Evanston: Northwestern University Press.

von Uexküll, J. (2010) A foray into the worlds of animals and humans, Minneapolis: University of Minnesota Press.

Wagner, P. (1999) 'After justification: Repertoires of evaluation and the sociology of modernity', European fournal of Social Theory 2 (3): 341-57.

(2006) 'Social theory and political philosophy', in Delanty, G. (ed.), Handbook of European social theory, London: Routledge.

Walby, S., Armstrong, J. and Stird, S. (2012) 'Intersectionality: Multiple inequalities in social theory', Sociology 46 (2): 224-40.

Walzer, M. (1984) Spheres of justice: A defense of pluralism and equality, New York: Basic Books.

(1995) 'Preface', in Sartre, J.-P. Anti-Semite and Few, New York: Schocken.

Warren, M. E. (1995) 'The self in discursive democracy', in White, S. K. (ed.), The Cambridge companion to Habermas, Cambridge University Press.

Weber, M. 1949 The methodology of the social sciences, New York: Free Press.

Weinstein M. and Weinstein D. (1971) 'Sartre and the humanist tradition of sociology', in Warnock. M. (ed.), Sartre, New York: Anchor.

White, S. K. and Farr, E. R. (2012) “No-saying” in Habermas', Political Theory 40 (1): 32-57.

Whitehead, A. N. (1997) Science and the modern world, New York: Free Press.

Wiener, N. (1954) The human use of human beings: Cybernetics and society, Boston: Da Capo Press.

Wiese, C. (2010) The life and thought of Hans fonas: fewish dimensions, Waltham, MA: Brandeis University Press.

Williams, S. J. (2005) 'Parsons revisited: from the sick role to ... ?', Health 9 (2): 123-44.

Wilson, E. O. (1978) On human nature, London: Penguin.

Wolin, R. (1993) 'Preface to the MIT edition: Note on a missing text', in Wolin, R. (ed.), The Heidegger controversy: A critical reader, Cambridge, MA: MIT Press.

(2001) Heidegger's children: Hannah Arendt, Karl Löwith, Hans fonas and Herbert Marcuse, Princeton University Press.

Wolters, G. (2001) 'Hans Jonas' philosophical biology', Graduate Faculty Philosophy fournal 23 (1): 85-98.

Wood, D. (ed.) (1993) Of Derrida, Heidegger and spirit, Evanston: Northwestern University Press.

Wrong, D. (1977) Skeptical sociology, London: Heinemann.

Young-Bruehl, E. (2004) Hannah Arendt: For love of the world, New Haven: Yale University Press.

Yuval-Davis, N. (2006) 'Intersectionality and feminist politics', European fournal of Women's Studies 13 (3): 193-209. 


\section{Index}

Locators in bold refer to figures and tables. Names as subentries refer to influence, critiques, interpretations and relationships of that person with the main subject.

abortion 206-9, 211-12, 218-23, 226 accountability 142 ; see also responsibility action

Arendt 64, 65

Parsons 88, 99-100, 101

active beings, Arendt 66

active life 64-5, 78-9, 82, 86

adaptation 1, 19, 87-9, 94, 107, 229; see also Parsons, $\mathrm{T}$.

AGIL model 89-99

health and illness 104-10

media theory 106-10

social systems 99-104, 106-10

agape $216-18$

agency, and social structure 181-4; see also autonomy

AGIL model (adaptation, goal attainment, integration, latency) 89-99, 107-8

alienation 5, 8, 77

Althusser, L. 11, 23-4, 34

analytical realism 89

animal laborans 66, 68-9, 82-3

animalitas 40-4

anthropocentrism 18-19, 63, 234-6

Archer 195-8

Habermas 139

Heidegger 39-40, 46

Jonas 117, 121, 122-9

Parsons 89, 93-9, 110

Sartre 33-4, 35

anthropological traits 1

anthropology, philosophical 3-7, 30-2, 229

Boltanski 209, 213

Habermas 138, 148

human need for 230-1

applied ethics 111; see also ethics

Archer, M. S. 1, 20-1, 181-4, 229; see also reflexivity autonomy 189-90, 198-205

orders of reality $188,191-8,200-2$

principle of humanity 184-90

Arendt, H. 1, 19, 64-5, 230; see also self-transcendence

Heidegger 80-2

modernity 82-6

relationships between humans and the world 65-71

thinking/thought 77-82

utilitarianism $71-7$

artificial intelligence 16-18, 114, 138; see also cybernetics

Austin, J. L. 137

authenticity 60, 61; see also jargon of authenticity; truth/validity

authoritarian politics 31 ; see also totalitarian regimes

Arendt 84

Jonas 131-2

Taylor 177-8, 180

authorship, human 33-4, 35, 62-3

autonomy; see also agency; freedom

Archer 189-90, 198-205

reflexivity 201

Bachelard, G. 34, 195, 234

Baehr, P. 84

Beaufret, J. 25, 35

Beck, U. 199-200

behaviour, standards of 71

Being Human (Archer) 183, 198; see also reflexivity

Being and Nothingness (Sartre) 25, 30-2

Being and Time (Heidegger) 25-6, 30-2, 53

being in the world (Dasein) 25, 30-2, 36, 41,49

Bendix, R. 10 
biological organisms 17-18; see also organic references

Heidegger 40-4

Jonas 111

Parsons 89-90; see also AGIL model

biological reductionism 89-90

biological sciences 5-6; see also philosophical biology

biology, philosophical 111, 112-17, 119, 123-4; see also Jonas, $\mathrm{H}$.

Blumenberg, H. 7, 15, 234-5; see also Copernican turn

Boden, M. 17

Boltanski, L. 1, 21, 206; see also reproduction of life

abortion 206-9, 211-12, 218-23, 226

justification 208-11, 213-16

love/agape 216-18

normative motifs $220,221,224-8$

philosophical anthropology 213

self-transcendence 216

Bourdieu, P. 9-10, 37, 199-200, 215

Braidotti, R. 14-16

capitalism 5, 131-2

caring 15, 43, 44

Cassirer, E. 4, 120

categorical imperative of morality 171 , 177-8, 204; see also Kant, I.

central conflation 181, 191, 199

Chernilo, D. 172, 179, 197, 214

Chomsky, N. 139, 143, 145, 146

Clark, A. 16-18

cognitive perspectives $16-18$

Habermas 137, 153, 157-8

Sartre 33-4

communication 137, 138-44; see also language

communicative action 136, 137, 138, 143, 152; see also Theory of Communicative Action (Habermas); Habermas, J. communicative competence 144-50, 157-8

communicative media 109; see also media theory

community $7,75,90,107,177$

community, world 75-6, 84

'concept of the self' 187-8, 194-5

Connolly, W. 14, 180, 212

consciousness 137; see also reflexivity

consensual theory of truth 154-7; see also truth/validity

constitutive goods 168

constructivism 18-19, 207, 222-3

consumer society 83,86 conversation, internal 184, 198-200, 201, 203-4; see also Archer, $M$.

Copernican turn 234-5

Cordero, R. 70, 157

cosmopolitan/ cosmopolitanism 47, 133, 134

cosmopolitan community, Kant's moral theory 75-6

cosmos, moral 161-2, 176-7

Crisis of European Science, The (Husserl) 54

critical theory 49, 134, 142, 149, 158, 190, 209, 231

Critique of Dialectical Reason (Sartre) 25

'critique of political economy' 2-3

Critique of Fudgment (Kant) 102

Laughing and Crying (Plessner) 7

culture $1,3,11,35,71,89,146,159,170$, $181,194,202,232$

cybernetics 100, 114, 138; see also artificial intelligence

Dahrendorf, R. 7-10

Dasein 25, 30-2, 36, 41, 49

Decline of the West (Spengler) 6

death

and natality 129-33

Parsons 103-4

Death in the Western World (Parsons) 93, 103-4

deconstructivism 207, 222-3

Deleuze, G. 14, 26, 37, 51, 63

democracy

Derrida 55-6

Habermas 138

Jonas 131-2

De Mul, J 7

Derrida, J. 18-19, 23-4, 26-7, 50-61, 135-6

description; see also description and normativity

description and normativity 118, 133, 173, 209, 224, 227

descriptive sociology 224-8, 230

developmental psychology 140

dignity: see human dignity

discourse principle 130, 152, 154; see also language; Habermas, J.

'downward' conflation 181, 191, 199; see also Archer, $M$.

duality 21-2; see also plurality

Archer 187-8

Arendt 78

Boltanski 208, 218-23

Jonas 119-21

Durkheim, E. 2

dystopianism 15 
economics, neo-classical 88

Einstein, A. 94

Elder-Vass, D. 181

elitism 15, 30, 33, 38, 45, 47, 60, 176

Heidegger 47, 61

Sartre 29-30

emancipation 3, 14, 47, 126

emotion 200-2, 203

empathy 32-3

empirical sociology. see scientific perspectives

ends and means, Kant's moral theory 72-3; see also categorical imperative

Ends of Man, The (Derrida) 23-4, 26-7

Enlightenment, the 172, 209-10

environmental perspectives 124-5

Enquiry into the Modes of Existence, An (Latour) 212

epistemological position; see also scientific perspectives

Kant 102

sociology in relation to philosophy 2

equality/inequality $71,129,210-11$

essentialism

abortion 207, 222

Habermas 140

ethics; see also morality

Jonas 111

naturalism 112-17, 118-21, 124-5

proceduralism 164-6, 172-3, 179, 204

realism 161-2

Eurocentrism 33, 55, 197

evaluations, strong; see strong evaluations evil 127

evolutionary universals 89-99, 236; see also AGIL model; Parsons, T.

existential uncertainty 103-4, 233

existentialism 113

Existentialism Is a Humanism (Sartre) 18-19, 23-4, 27-35

expressive nature 170

extended mind thesis 16

exteriority 67

external reality 155; see also truth/validity

Family Idiot, The (Sartre) 24

Farías, V. 37

Faye, E. 37-8

field 37

Fine, R. 64

flesh 218-23

Foetal Condition, The (Boltanski) 208, 211-12

foetus, abortion 206-9, 211-12, 218-23, 226
Formation de L'Esprit Scientifique, La

(Bachelard) 34, 195, 234

Foucault, M. 57, 135-6

foundationalism 34, 35

freedom; see also autonomy

Arendt 82-3

individual $2,8,13,17,20,27,32,34,52$, $66,69,74,80,87,95,98,103,117$, 129, 145, 159, 169, 176, 193

moral 4, 29, 68, 72, 75, 101, 125, 126, $127,140,152,155,161-8,173-80$, 190, 203, 204, 218, 227

Jonas 113-14

Sartre 28, 32, 61

Freud, S. 104

Fuller, S. 16, 90

functionalism 114

Gadamer, H.-G. 136

games, linguistic 153

Gehlen, A. 7

Geist (spirit) 52-5; see also selftranscendence

Giddens, A. 171, 182

Gnosticism 112-13

goal attainment 94, 107; see also AGIL model

God 102; see also religion; selftranscendence

good, the $162,172-3$

goods, constitutive 168

goods, moral 163

Gouldner, A. W. 87

Guattari, F. 14, 26, 37, 51, 63

Haar, M. 41-2

Habermas, J. 21, 130-1, 134-8; see also language

communicative competence 144-50

Heidegger 44-6

human communication 138-44

Jonas 130-1

truth/validity 150-8

habitus 37, 199-200

Haraway, D. 212

Harré, R. 182

health and illness 104-10

Hegel, G. 42, 52, 57, 77, 117, 162, 165, 172

Heidegger, M. 18-19, 23-4, 25-6, 30, 35-50, 233-4

Arendt 80-2

Jonas 112-13, 118

Sartre 30-2, 39

Heidegger and Nazism (Farías) 37

historicism 28, 181 


\section{homo faber}

Arendt 66, 68-9, 71-7, 82-3

Jonas 117

homo oeconomicus 87,161

homo significans 196

homo sociologicus 7-10, 121, 143

Honneth, A. 7, 191, 209

human authorship 33-4, 35, 62-3; see also anthropocentrism

human being; see also humanity

human communication 137, 138-44; see also language

human condition

Arendt 64-5

Parsons 90, 93-9, 108

Human Condition, The (Arendt) 64-5, 77

human dignity 236

Boltanski 211

Derrida 60

Kant's moral theory 74-5

Sartre 33-4, 35, 61

human identity: see identity

Human Place in the Cosmos, The (Scheler) 4

human sociality, sixth sense $67-8$

humanism 18-19, 23-4, 61-3, 236

Braidotti 14-16

Derrida 26-7, 50-61

Heidegger 25-6, 35-50

Sartre 24-5, 27-35

Taylor 172

humanist prejudice 234; see also anthropocentrism

humanitas 40, 46, 47, 49; see also Heidegger, $M$.

humanity; see also human beings; species being

principle of 231; see also universalistic principle of humanity

Archer 184-90

Boltanski 213, 218-23, 226

social sciences 233-4

human life $6,7,19-21,30,35,40,48,62$, 65, 67, 70, 79, 86, 89, 96-110, 111, 123-9, 132, 163, 180, 196, 206, 207, 219-23, 236

human nature $5,7,8,10,28,65,70,85,86$, $91,111,123,134,157,160,171,199$, $219,223,233$

human rights 53, 156

human species $28,33,74,78,87,99,138$, 185,221

Husserl, E. 6, 54

anthropocentrism 234
Habermas 150

Jonas 120

hypergoods $164-6$

idealisation 142-3

idealism

identity

Archer 194-5

Taylor 159, 160, 175, 179; see also modern self; strong evaluations

illness 104-10

impartiality, Kant's moral theory 75

imperative of responsibility 111, 124-5; see also responsibility, Jonas, $\mathrm{H}$.

inclusivity 130-1

individual 32, 52, 66-74, 80, 87, 95, 106, $109,160,168-73,208$

individualism 27-8, 87

individuality

inequality $71,129,210-11$

innate linguistic capacity 143

integration 94, 107-8; see also

AGIL model

internal conversation 184, 198-200, 201, 203-4; see also Archer, M.

International Sociological Association 197

intersubjectivity 67-8

Habermas 137

Jonas 111

Sartre 27-8

irrationalism 135-6

jargon of authenticity 38

Jaspers, K. 45, 55, 85

Jews 28, 132

Jonas, H. 111-12; see also responsibility

Joas, $\mathrm{H}$.

anthropocentrism 122-9

ethical naturalism 112-17

humanist values 118-21

natality 129-33

judging $64,77-8$

justice/justification 208-11, 213-16; see also Boltanski, L.

Fustice in Robes (Dworkin) 225

Kant, I. 58-9, 230-1

Habermas 137, 143

Jonas 120, 131-2

moral theory 72-7

Parsons 101-3

Taylor 177-8

King, M. Luther 55 
Klemperer. V. 52

Knowledge and Human Interest

(Habermas) 134

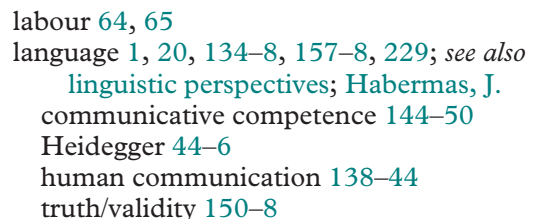

latency 94-5, 108; see also AGIL model

Latour, B. 11-14, 212

Lectures on Kant's Political Philosophy (Arendt) 73

Letter on Humanism (Heidegger) 18-19, 23-4, 25-6, 35-50, 56-7, 81

Levinas, E. 23, 39, 46, 48, 49, 125, 211

Life of the Mind, The (Arendt) 64-5, 77

life, reproduction. see reproduction of life

lifeworld

Arendt 66

Boltanski 227

Habermas 150-8

linguistic perspectives

Archer 192-4, 199; see also internal conversation

Taylor 164

linguistic turn 136, 138-44; see also language

love 216-18

Löwith, K. 5, 38, 41, 116-17

Luhmann, N. 108-9, 234

Lyotard, J.-F. 26, 35, 37, 63

McCarthy, T. 134, 144, 154

Marcuse, H. 3, 49, 120, 172

Marquard, O. 7

Marx, K. 2-3, 5, 82

Marxism and Humanism (Merleau-Ponty) 22 material environment of objects 64,65

materiality 83,86

Mauss, M. 187, 198

Max Weber and Karl Marx (Löwith) 5

Mead, G. H. 140, 182

meaning, symbolic 137, 139-40

Meaning in History (Löwith) 175

means and ends, Kant's moral theory 72-3

media theory 106-10

meditation 43, 44, 49

meta-communication 153-4

metaphysics 13, 25, 38-43, 50-62, 71, 81, $102,111,115,120,159,160,195$, 209, 217

Mills, C.W.

Mills, J. S. 182 modern self, 159-60, 161, 169-74, 179; see also strong evaluations; Taylor, C.; self

modernity

Arendt 82-6

Heidegger 49

posthumanism 10-18

modus vivendi 191, 203-4

monotheism 70

moral goods 163

moral proceduralism 164-6, 172-3, 179, 204

moral theory, Kant 72-7

moral universe/cosmos 161-2, 176-7

morality and self, 160-9, 176-7; see also ethics; values

natality 129-33; see also Jonas, $H$.

natural environment 65

natural law 134, 170, 171-3

natural orders of reality 191-8, 202-3

naturalism; see also philosophical biology

Heidegger 40-4

Jonas 112-17, 118-21, 124-5, 127-8

Latour 11-14

racist 44

Taylor 167, 171-2, 176-7

nature $11,12,17,19,20,35,40$

transcendental 102; see also selftranscendence

Nausea (Sartre) 24, 30

Nazism

Heidegger 31, 37, 51-6

Jonas 112-13

Taylor 176

networks 11-14

Nietzsche, F. 42, 46, 81, 166-7

nihilism 39-40; see also nothingness

normative ideas of humanity 33

normative motifs $1-2,7-10,230$

Archer 188-9

Arendt 84-5

Boltanski 220, 221, 224-8

Habermas 142

Jonas 115, 118-21, 123

Latour 13

Parsons 92

Sartre 33-4

Taylor 161, 163, 164, 178-9

normativity; see also description and normativity

nothingness 39-40

Jonas $112-13,118$

Sartre 27

objectivity 118-21; see also scientific perspectives

obligation/oughts, ontological 128 
On Fustification (Boltanski and Thévenot) 208-11

Order of Things, The (Foucault) 57

orders of reality 188, 191-8, 200-2

ordinary life 170

organic references 233; see also biological organisms

Boltanski 226

Clark 17-18

Heidegger 40-4

Jonas 113-17

Parsons 89; see also AGIL model Origins of Totalitarianism (Arendt) 84 oughts, ontological 128

parental project 220; see also reproduction of life

Parsons, T. 87-9; see also adaptation AGIL model 89-99

health and illness 104-10

media theory 106-10

social systems 99-104, 106-10

particularity $12,70,76,113,157$

performative order of reality 191-8

perpetual peace 47, 133, 134; see also Kant; cosmopolitanism

philosophers 21

philosophical anthropology; see anthropology, philosophical sociology

philosophical biology 111, 112-17, 119, 123-4

philosophical sociology 2, 7-10, 85, 88, 111-12

philosophy 231

and scientific perspectives 231-3

Piaget, J. 146

Plessner, H. 7

plurality; see also duality

Arendt 70-1, 78, 86

Jonas 131-2

Taylor 174, 178-9

political economy, critique of 2-3

political equality $71,129,210-11$

positivism 2

posthumanism 10-18, 190

postmetaphysical 135

Postmetaphysical Thinking (Habermas) 6

postmodernism 197

power theories

Boltanski 215-16, 220

Taylor 166-7

practical order of reality 191-8

principle of humanity: see humanity

Principle of Hope (Bloch) 126

pristine nature 170,172

private and public $138,157-8$ proceduralism, ethical 164-6, 172-3, 179, 204

progress 34, 74, 126, 130, 214

racist naturalism 44; see also Nazism radical subjectivism 170; see also subjectivism

rationality 203; see also objectivity

Rawls, J. 130-1

realism, ethical 161-2

Realist Social Theory (Archer) 182, 184; see also reflexivity

reality, external 155; see also truth/validity

reconciliation, humanism 34, 43, 60-1, 62

Rectorship Address (Heidegger) 53

reductionism, biological 89-90

Reflexive Imperative in Late Modernity, The (Archer) 198

reflexivity 1, 20-1, 181-4, 229; see also Archer, M.

autonomy 189-90, 198-205

Habermas 153-4

orders of reality $188,191-8,200-2$

principle of humanity 184-90

relativism 233

Habermas 136, 155

Heidegger 39-40

Kant 102

Sartre 28

religion 92; see also God; self-transcendence renewal 86

reproduction of life 1, 21, 206, 229; see also Boltanski, L.

abortion 206-9, 211-12, 218-23, 226

justification 208-11, 213-16

love/agape $216-18$

normative motifs $220,221,224-8$

philosophical anthropology 213

self-transcendence 216

responsibility 1, 19-20, 111-12, 122-9, 229; see also Jonas, $\mathrm{H}$.

anthropocentrism 122-9

Derrida 52-3

ethical naturalism 112-17

Habermas 142

humanist values $118-21$

imperative of $111,124-5$

natality 129-33

Sartre 32

robots 16-18; see also cybernetics

Rockmore, T. 36, 37-8

Rorty, R. 137, 168, 182

Rose, G. 17, 172

Rousseau, J. 170, 171 
Saint Genet (Sartre) 24

Sartre, J.-P. 18-19, 23-4, 27-35, 39, 233-4; see also Existentialism Is a Humanism; humanism; anthropocentrism

Savage Mind, The (Levi-Strauss) 23

scandal of reason 73, 230-1, 233; see also thinking/thought

Scheler, M. 4, 17

Schelsky, H. 7

Science and Technology as Ideology (Habermas) 138

scientific perspectives 2, 4, 6; see also anthropology; sociology/ social sciences

Archer 188-9, 196

Derrida 58

Jonas 119-21, 123-4

Parsons 100, 109-10

and philosophy 231-3

Searle, J. 17, 139

Second World War 7

self

morality and 160-9, 176-7

sense and concept of $187-8,191,194-5$

self-awareness 186; see also reflexivity

self-knowledge 232-3; see also reflexivity

self-legislation 129-30, 132-3

self-preservation 116-17, 132-3

self-transcendence 1, 19, 64-5, 68-9, 229, 231; see also Arendt, $\mathrm{H}$.

Archer 199; see also reflexivity

Boltanski 209-10, 216

Derrida 60

Habermas 143

Jonas 116-17, 121, 122

Kant 72-7

modernity 82-6

nature, god and the soul 102

relationships between humans and the world 65-71

Sartre 30

Taylor 163

thinking/thought 77-82

utilitarianism 71-7

self-worth 191, 202

sense of self 187-8, 191, 194-5

Sense and Non-sense (Merleau-Ponty)

sick role 104-10

Simmel, G.

sixth sense, human sociality $67-8$

Sloterdijk, P.

social bond 216

social constructivism 18-19, 207, 222-3

social imaginaries 163

social inequality $71,129,210-11$ social life $2,9,10,62,82,85,101,112,126$, 136, 142, 162, 183-94, 204, $212-18,230$

social media 109; see also media theory social mobility 201

social relations $70,84,87,89,110,111$, 194, 213, 218

social sciences. see sociology/ social sciences social structure, and agency 181-4

Social System, The (Parsons) 87-9

social systems

Jonas 111-12

media theory 106-10

Parsons 99-104

social theory $3,21,33,134,137,159$, $182-8,191,206$

socialisation. see adaptation

sociality, human $67-8$

societal community $90,107-8$

society $1,3,8,12,15,29,35-8,48,76,77$, 83, 87-99, 106-8, 111, 120-8, 134, 169-99, 200-5, 209-22, 227

modern $36,38,50,77,83,84,149$, 169,217

theory of $111,134,140,149,153,158$

Western 159

sociality $186,212,216$

sociocultural environments, action and speech 65

sociologists 21

sociology/ social sciences $7-10$

descriptive vs normative $224-8$

abortion 207

Archer 188-9, 199

Arendt 83-6

philosophical 2-3, 7-10, 85, 88, 111-12

principle of humanity $233-4$

Taylor 171

Sociology and Human Nature (Dahrendorf) 7 soul 102; see also self-transcendence

Sources of the Self (Taylor) 159-60, 169, 175,178 ; see also strong evaluations speech act theory 65,137 ; see also communicative action; language

species being; see also human being; humanity

Spheres of Fustice (Walzer) 208-11

spirit (Geist) 52-5; see also selftranscendence

standards of behaviour 71

Strauss, L. 23, 71, 84, 85, 161

strong evaluations 1, 20, 159-60, 203, 229; see also Taylor, C.

critical assessment of 174-80

modern self $169-74,179$

morality and self $160-9,176-7$ 
structural functionalism 87

structure, and agency 181-4

Structure of Social Action (Parsons) 100

subjectivism 27, 35, 39; see also reflexivity

Archer 181, 183, 196, 198

Heidegger 39-40, 53, 81

Sartre 27-8, 35

Taylor 170

suicide 131-2

symbiotic mechanisms 109

symbolism/symbolic

meaning 137, 139-40

media 106-10

violence 37

system of action 99; see also action

Taylor, C. 159-60; see also string evaluations

critical assessment of 174-80

modern self 169-74, 179

morality and self 160-9, 176-7

technology

Boltanski 221

Heidegger 48

Sartre 35

teleology

Temps Modernes, Les journal 31

terror 173

theology 232, 234

Theory and Practice (Habermas) 134

Theory of Communicative Action (Habermas) $138,141,148-50,157$

Thévenot, L. 21, 208-10, 217

thinking/thought 64; see also vita contemplativa

Arendt 77-82

experiments 18

Tillich, P. 176

Tönnies, F. 232

totalitarian regimes; see also authoritarian politics

Arendt 84

Taylor 177-8, 180

transcendental ordering 108; see also selftranscendence

transvaluation 14, 46, 166-7, 203; see also values

tripartite classification, plants, animals and humans 4, 17; see also philosophical anthropology

truth/validity $137,141,150-8$

Turing, A. 16, 17, 146, 200

ultimate concerns 194, 203; see also Archer, M.; Taylor, C. uncertainty, existential 103-4, 233

universal empathy 32-3

universal pragmatics $135,146,147-8,149$, 154-7; see also Habermas, J.

universalism 33, 91, 93, 133, 135, 156, 160, $165,169,178,180,204,211$

cultural 91, 93, 211

procedural 166

universalistic principle of humanity 1, 4-5, 230, 236; see also evolutionary universals

Archer 184-90, 197

Boltanski 210-11

Jonas 126

Sartre 32-3

Taylor 164

universe/cosmos, moral 161-2, 176-7

unworldliness 78

upward conflation 181, 191, 199; see also Archer, M.

utilitarianism

Archer 203

Arendt 71-7

validity/truth 137, 141, 150-8; see also Habermas, J.

values 18-19; see also ethics; morality

Jonas 118-21

Sartre 28, 29

Taylor 161

transvaluation 14, 46, 166-7, 203

violence, symbolic 37

vis medicatrix 105

vita activa 64-5, 78-9, 82, 86; see also Arendt, $\mathrm{H}$.

vita contemplativa 64-5, 77-9, 82, 86; see also thinking/thought

Voegelin, E. 52, 71, 84, 113, 232

Wagner, P. S. 171, 208

We Have Never Been Modern

(Latour) 13

Weber, M. 2, 5

What Is Called Thinking?

(Heidegger) 81

What Is Literature? (Sartre) 32

Whitehead, A. N. 89

Wiener, N. 94, 138

will-not-to-will 81-2

willing 64, 77-8

withdrawal 86

Wolin, R. 51, 112, 116

work 64, 65

world community 75-6, 84

Wrong. D. 87 